UNIVERSIDADE DE SÃO PAULO - USP

PROGRAMA DE PÓS-GRADUAÇÃO EM EDUCAÇÃO - FEUSP

ANDRÉIA FERNANDA MOLETTA

A CONSTRUÇÃo dA PRÁTICA PEDAGÓGICA POR PROFESSORES UNIVERSITÁRIOS DE EDUCAÇÃO FÍSICA JOVENS DOUTORES 


\section{A CONSTRUÇÃO DA PRÁTICA PEDAGÓGICA POR PROFESSORES UNIVERSITÁRIOS DE EDUCAÇÃO FÍSICA JOVENS DOUTORES}

\section{Versão Original}

Tese apresentada ao Programa de Pós-graduação em Educação da Faculdade de Educação da Universidade de São Paulo para obtenção do título de Doutora em Educação.

Área de Concentração: Formação, Currículo e Práticas Pedagógicas

Orientadora: Prof ${ }^{a}$ Dra. Karina Soledad Maldonado Molina

São Paulo 
Autorizo a reprodução e divulgação total ou parcial deste trabalho, por qualquer meio convencional ou eletrônico, para fins de estudo e pesquisa, desde que citada a fonte.

Moletta, Andréia Fernanda
A CONSTRUÇÃO DA PRÁTICA PEDAGóGICA POR
PROFESORES UNIVERSTÁRIOS DE EDUCAÇÃo FÍSICA
JovENS DOUTORES / Andréia Fernanda Moletta;
orientador Karina Soledad Maldonado Molina . - São
Paulo, 2019.
281 p.
Tese (Doutorado - Programa de Pós-Graduação
Formação, Currículo e Práticas Pedagógicas) --
Faculdade de Educação, Universidade de São Paulo,
2019.
1. Práticas Pedagógicas. 2. Professores
Universitários. 3. Educação Física. 4. Jovens
Doutores. I. Karina Soledad Maldonado Molina,
orient. II. Título.


MOlettA, A. F. A Construção da Prática Pedagógica por Professores Universitários de Educação Física Jovens Doutores 2019. 281 f. Tese (Doutorado em Educação) Faculdade de Educação, Universidade de São Paulo, São Paulo, 2019.

Aprovado em:

\section{Banca Examinadora}

Profa. Dra. Karina Soledad Maldonado Molina

Instituição: Universidade de São Paulo

Julgamento:

Profa. Dra. Sonia Maria Ribeiro

Instituição: Universidade da Região de Joinville

Julgamento:

Profa. Dra. Sylvia Helena Souza da Silva Batista

Instituição: Universidade Federal de São Paulo

Julgamento

Profa. Dra. Mariângela da Rosa Afondo

Instituição: Universidade Federal de Pelotas

Julgamento

Profa. Dra. Paula Perin Vicentini

Instituição: Universidade de São Paulo

Julgamento 


\section{DEDICATÓRIAS}

A minha mãe, Sônia Maria Franczak, que foi fundamental para realizações dos meus sonhos, que me acompanhou nesta caminhada e superou a distância que nos separava.

Aos meus irmãos, André Fernando Moletta (in memoriam) e Andreza Aline Moletta (in memoriam), e meu avô, Alfredo Moletta (in memoriam), que iluminaram meu caminho e me acompanharam espiritualmente nesta jornada.

Aos meus afilhados, Larissa e Davi, e minha irmã Aline Krein Moletta, que o presente estudo lhes incentive a nunca desistirem de seus sonhos, pois é possível alcançá-los quando se acredita. 


\section{AGRADECIMENTOS}

A Deus, por sempre me guiar pelos bons caminhos percorridos e acalentar sempre meu coração ansioso através de uma palavra e carinho das pessoas próximas a mim.

A minha mãe (Sônia), foi minha base em todo essa jornada, pois sempre acreditou em mim não deixando cair ou desistir do caminho que escolhi para trilhar, por mais difícil que foi...

Ao meu pai (André), minha irmã (Aline), minha madrasta (Silvana), minha vó (Casimira), minhas primas (Priscila e Juliana) e minha madrinha (Tia Lilia) pelo acolhimento e a compreensão da minha ausência.

A minha orientadora, Prof ${ }^{a}$. Dra. Karina Soledad Maldonado Molina que me abraçou e me ajudou a continuar a trilhar esse caminho. Sempre esteve disposta e de bom humor para me ajudar. Obrigada por tudo, serei sempre grata pelo apoio e sustentação nesse processo de doutoramento.

Aos meus amigos, compadres e afilhados que compreenderam minha ausência e nunca deixaram da me apoiar e acreditar em mim. Mas gostaria de agradecer em especial minhas amigas Michele Dalmazo, Daniela de Farias e Marília Garcia estiveram esses últimos quatro anos ao meu lado na alegria e na tristeza. “[...] Lagrimas na vitória, sempre da derrota ou glória, é luz na escuridão, somos um só coração, sempre vivo na memória, faz parte da minha história, nada vai nos separar, a amizade é tudo!" (Rodrigo Fernando Amaral Silva / Thiago André Barbosa).

Ao meu companheiro diário Isaias Ravizza pelo apoio e compreensão nessa fase e por todas as vezes que me fiz ausente no nosso relacionamento. Obrigada por me proporcionar paz e tranquilidade nessa fase.

As minhas amigas que a Faculdade de Educação da Universidade de São Paulo FESUP me trouxe - Camila e Regina - me ajudaram a construir conhecimento sobre a teoria de Claude Dubar.

A Prof ${ }^{a}$. Dra. Maria Isabel da Cunha e o Prof. Dr. Marcos Neira que me acolheram nesse início de formação, me oportunizando a realizar o doutorado na FEUSP.

Aos professores e funcionários da FEUSP que sempre estiveram a disposição para me ajudar em minha formação.

Ao Núcleo de Pesquisa em Pedagógica do Esporte - NuPPE da Universidade Federal de Santa Catarina - UFSC pela disponibilidade dos materiais para coleta de dados. Em 
especial aos integrantes Ricardo Quinaud, Carine Collet, Fabrício João Milan e Felipe Goedert Mendes que me auxiliaram na coleta de dados.

Aos professores e funcionários da Faculdade IELUSC e da Escola Municipal Monsenhor Sebastião Scarzello da cidade de Joinville pelo apoio e compreensão nesse período de doutoramento.

Aos membros da banca examinadora que disponibilizaram de seu tempo e conhecimento para contribuir em minha formação acadêmica e profissional.

A Professora Nádia que sempre esteve a disposição para revisar os meus textos.

A universidade que disponibilizou a realização da coleta de dados e pelos docentes jovens doutores que foram essenciais dessa pesquisa. Minha gratidão pelo carinho e confiança. 


\section{RESUMO}

MOlettA, A. F. A Construção da Prática Pedagógica por Professores Universitários de Educação Física Jovens Doutores. 2019. 281f. Tese (Doutorado em Educação) Faculdade de Educação, Universidade de São Paulo, São Paulo, 2019.

O presente estudo tem como objetivo investigar o processo de construção da prática pedagógica de docentes, jovens doutores, que atuam nos cursos de Educação Física, a partir dos processos subjetivos e objetivos da formação pessoal e profissional. A base teórica articula a produção de Goffman (1988) e Dubar (2005), buscando-se: reconhecer a identidade real e a identidade virtual dos docentes; identificar e compreender a construção e o desenvolvimento das práticas pedagógicas dos professores e averiguar as implicações das construções biográficas e subjetivas na consolidação da prática pedagógica. A fim de alcançar os objetivos propostos, foi realizado um estudo qualitativo do tipo exploratório, na primeira fase foi realizada uma pesquisa documental a partir dos currículos vitae para identificar o percurso profissional dos professores, plano de ensino, cronograma de aula e histórico escolar das disciplinas cursadas na graduação e pós-graduação (lato sensu e stricto sensu). Na segunda fase foram realizados: a) entrevista, utilizando o método de história oral, norteada pela história de vida, a partir das narrativas biográficas; b) estudo de campo, a partir do acompanhamento e observações das aulas e suas gravações; c) uma entrevista semiestruturada, fundamentada na análise da história de vida e gravações das aulas. Para compreensão das informações coletadas foi através da triangulação das fontes de dados. Os participantes são professores universitários de Educação Física, atuantes em uma instituição pública do estado de Santa Catarina, os quais finalizaram o curso de doutoramento e ingressaram como docentes nessa IES nos anos de 2013 e 2014. O projeto de pesquisa foi submetido e aprovado pelo Comitê de Ética em Pesquisa com Seres Humanos (CEP), cumprindo todos os aspectos éticos a partir do parecer $\mathrm{n}^{\circ}$ 284.026.9. As trajetórias pessoais e profissionais dos jovens doutores foram marcadas a partir das relações e experiências consolidadas em suas socializações primária e secundária, as quais apresentaram aproximações em alguns momentos, tais como o esporte e a pesquisa que contribuíram de forma significativa para a construção de suas identidades. O modelo identitário presente no grupo foi a de responsável em promoção interna, atrelado do modelo "carreirista" ao processo de mobilização. As práticas pedagógicas docentes apresentaram intencionalidades, mostrando que os professores superaram aulas do tipo expositiva, usufruem de diferentes estratégias de ensino e de recursos materiais, compreendem a avaliação como um processo a partir do uso de instrumentos e realizada em diferentes períodos. Ainda carecem de um trabalho coletivo com outros professores e aproximação com extensão universitária, considerando o fato de que a pesquisa se encontra presente, mesmo que timidamente. As contribuições da trajetória pessoal estiveram relacionadas aos contextos: familiar, esportivo e do ambiente escolar, contudo o esporte ocupa lugar de destaque, o que se modifica quando iniciam a descrição da formação acadêmica e experiências como docente no Ensino Superior. Em virtude disso, comprovamos a tese de que as práticas pedagógicas dos professores jovens doutores de Educação Física foram construídas a partir das experiências e conhecimentos adquiridos ao longo da sua socialização primária e secundária, as quais contribuíram para a construção de suas identidades. Além disso, o esporte foi um elemento fundante em suas identidades - pessoal, social e profissional - revelando que as práticas esportivas contribuíram para uma formação cidadã, mas também direciona a uma prática profissional. Assim, compreendemos que essa escolha pela docência está mais atrelada às questões científicas do que a prática docente em si, e que o sistema universitário não contribui para 
uma percepção diferente devido às inúmeras atribuições referentes à pesquisa e publicações em detrimento do ensino.

Palavras-Chave: Docência Universitária. Jovem doutor. Prática Pedagógica. Educação Física. 


\begin{abstract}
MOLETTA, A. F. The construction of pedagogical practice by university professors of physical education young doctors. 2019. 281f. Tese (Doutorado em Educação) - Faculdade de Educação, Universidade de São Paulo, São Paulo, 2019.
\end{abstract}

The present study aims to investigate the process construction of the pedagogical practice of teachers, young doctors, who works in the Physical Education course, from the subjective and objective processes of personal and professional formation. The theoretical basis articulates works of Goffman (1988) and Dubar (2005), looking for: recognize the real identity and virtual identity of teachers; identify and understand the construction and development of teachers' pedagogical practices and investigate the implications of biographical and subjective constructions consolidation of pedagogical practice. In order to reach the proposed objectives, a qualitative study of the exploratory type was carried out, in the first phase a documentary research was carried out from the curriculum vitae to identify the professional path of the teachers, teaching plan, class schedule and school history of the disciplines undergraduate and post-graduate studies (lato sensu and stricto sensu). In the second phase, the following was performed: a) interview, using the oral history method, guided by the life history, based on the biographical narratives; b) field study, from the monitoring and observations of the classes and their recordings; c) a semi-structured interview, based on the analysis of the life history and class recordings. To understand the information collected, the triangulation of the data sources were used. The participants are university professors of Physical Education, working in a public institution of the state of Santa Catarina, who finished the doctoral course and entered as a teacher in this IES in the years of 2013 and 2014. The research project was submitted and approved by the Committee on Ethics in Research with Human Beings (CEP), fulfilling all the ethical aspects based on opinion $\mathrm{n}^{\mathrm{o}} 284.026 .9$. The personal and professional trajectories of the young doctors were marked by the relationships and experiences consolidated in their primary and secondary socialization, which presented approximations in some moments, such as sport and research that contributed significantly to the construction of their identities. The identity model present in the group was that of responsibility for internal promotion, linked from the "careerist" model for the mobilization process. Teaching pedagogical practices presented intentions, showing that teachers have passed lectures of the expository type, enjoy different teaching strategies and material resources, understand evolution as a process for the use of instruments and carried out in different periods. They still lack a collective work with other professors and approach with university extension, because the research is present, even if, timidly. The contributions of the personal trajectory were related to the contexts: family, sport and the school environment, with sport occupying a prominent place, which changes when the academic formation and experiences as a teacher in Higher Education begin. As a result, we prove the thesis that the pedagogical practices of young teachers of physical education were built on the experiences and knowledge acquired during their primary and secondary socialization, which contributed to the construction of their identities. Besides, the sport was a fundamental element in their identities - personal, social and professional - revealing that sporting practices contribute to a citizen's formation, but also lead a professional practice. Thus, we understand that this choice for teaching is more tied to scientific issues than the teaching practice itself and that the university system does not contribute to a different perception due to the numerous attributions related to research and publications to the detriment of teaching.

Key Words: University Teaching. Young doctor. Pedagogical Practice. Physical Education. 


\section{LISTA DE ANEXOS}

ANEXO A - Autorização da Universidade Investigada para Coleta Das Informações....259 ANEXO B - Aparecer de Aprovação do Comitê de Ética de Pesquisa com Seres Humanos $-\mathrm{CEP}$ 260

ANEXO C-Aparecer da Emenda do Comitê de Ética de Pesquisa com Seres Humanos CEP .264 


\section{LISTA DE APÊNDICES}

APÊNDICE A - Roteiros de questões para entrevista estruturada ..................................268

APÊNDICE B - Termo de Consentimento Livre e Esclarecido aos Participantes.......... 277

APÊNDICE C - Termo de Consentimento Livre e Esclarecido aos Participantes ...........279 


\section{LISTA DE FIGURAS}

Figura 1 - Total de matrículas na pós-graduação por região e proporção de matrículas por dez mil habitantes, Brasil, 2000 . . .46

Figura 2 - Nuvem de palavras referente aos autores mais indicados como base teórica ....62 Figura 3 - Distribuição dos cursos de Formação Inicial em Educação Física de 1935 a 2013

Figura 4 - Percentual de distribuição da carga horária das disciplinas dos cursos de licenciatura e bacharelado em Educação Física por dimensão do conhecimento e das atividades complementares como parte da carga horária total do currículo

Figura 5 - Relações dos conceitos das identidades social, pessoal e do eu com estigma...117 Figura 6 - Modelo do distanciamento ao processo de exclusão: a identidade de executor “estável” ameaçada do operário e do professor.

Figura 7 - Modelo do operário ao "novo profissional": a identidade bloqueada a partir operário e do professor.

Figura 8 - Do modelo "carreirista" ao processo de mobilização: a identidade de responsável em produção interna de operários e docentes.

Figura 9 - Do "modelo afinitário" ao processo de recapacitação: a identidade autônoma e incerta de assalariados e professores

Figura 10 - Modelos Profissionais Docentes atuantes no Ensino Superior na área da Saúde

Figura 11 - Organização da Metodologia da Pesquisa 133

Figura 12 - Esquema conceitual para abordagem qualitativa.....

Figura 13 - Trajetória acadêmica dos professores jovens doutores até efetivação docente .182

Figura 14 - Socialização primária e secundária dos professores de Educação Física jovens doutores

Figura 15 - Configuração identitária dos professores de Educação Física jovens doutores 196

Figura 16 - Componentes do plano de ensino dos professores de Educação Física jovens doutores

Figura 17 - Metodologia desenvolvida pelos professores de Educação Física jovens doutores 
Figura 18 - Organização das aulas observadas dos professores de Educação Física jovens

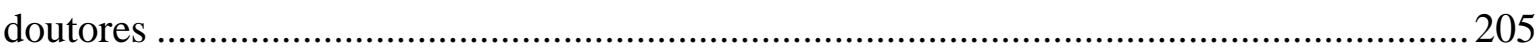

Figura 19 - Utilização de recursos audiovisuais por Abel ..............................................2 211

Figura 20 - Utilização de recursos audiovisuais por Larissa ...........................................212

Figura 21 - Utilização de recursos audiovisuais por Eriberto ..........................................2 212

Figura 22 - Utilização de recursos audiovisuais e lousa por Felipe ................................212

Figura 23 - Avaliações das atividades desenvolvidas nas aulas dos jovens doutores ......215 Figura 24 - As contribuições das socializações primária e secundária para as práticas

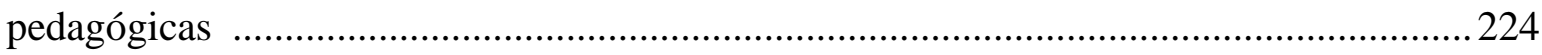




\section{LISTA DE GRÁFICOS}

Gráfico 1 - Distribuição dos programas/cursos de pós-graduação por grau . .43

Gráfico 2 - Distribuição dos programas de pós-graduação por status jurídico . .44

Gráfico 3 - Distribuição dos programas/cursos de pós-graduação por regiões do Brasil .....45

Gráfico 4 - Distribuição dos discentes dos programas de pós-graduação. . .48

Gráfico 5 - Distribuição do ano de Formação em Doutorado dos Professores de Educação Física do Ensino Superior da IES participante. 136

Gráfico 6 - Construção e produção do conhecimento ao longo do mestrado. .172

Gráfico 7 - Construção e Produção do conhecimento ao longo do doutorado... 180

Gráfico 8- Orientações acadêmicas realizadas pelos jovens docentes 185

Gráfico 9 - Produção do conhecimento dos professores jovens ao longo da trajetória acadêmica e profissional 186

Gráfico 10 - Bibliografias Básicas e Complementares utilizadas pelos professores de Educação Física jovens doutores 216 


\section{LISTA DE QUADROS}

Quadro 1 - Cursos, modalidades e denominações ........................................................ 40

Quadro 2 - Dilemas na formação de professores universitários ......................................55

Quadro 3 - Teorias do currículo suas características, principais modelos e autores............69

Quadro 4 - Comparação dos cursos ministrados pela Escola Nacional de Educação Física e

Desportos conforme os decretos-lei $\mathrm{n}^{\mathrm{o}} 1.212 / 39$ e 8.270/45 ............................................ 79

Quadro 5 - Comparação das dimensões de conhecimento dos Cursos de Educação Física

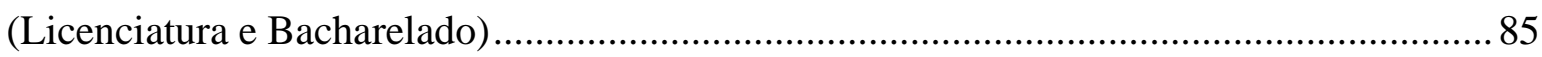

Quadro 6 - Artigos que abordam sobre os cursos de pós-graduação lato sensu enquanto formação continuada na Educação Física fundamentado na pesquisa de Cruz Junior (2010)

Quadro 7 - Categorias de análise da identidade. 114

Quadro 8 - Componentes curriculares que contemplam os conhecimentos pedagógicos ao longo da formação inicial dos professores de Educação Física jovens doutores 164 Quadro 9 - Experiências em pesquisa, ensino, extensão e espaços fora da universidade ao

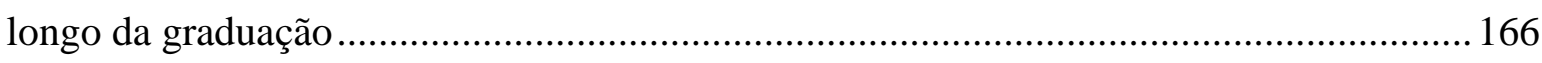

Quadro 10 - Disciplinas realizadas ao longo do Mestrado ........................................... 170

Quadro 11 - Disciplinas cursadas ao longo do doutorado .............................................. 178

Quadro 12 - Disciplinas lecionadas como professor efetivo da UPC .............................. 183

Quadro 13 - Modelos, características e pressupostos da formação docente conforme Cunha (2012; 2014). 


\section{LISTA DE TABELAS}

Tabela 1 - Retrato dos cursos de pós-graduação lato sensu de Didática e Metodologia do Ensino Superior e Docência no Ensino Superior

Tabela 2 - Dados sobre a carga horária e as vagas ofertadas nos cursos de pós-graduação lato sensu de Didática e Metodologia do Ensino Superior e Docência no Ensino Superior

Tabela 3 - Distribuições de oferta dos cursos de pós-graduação lato sensu de Didática e Metodologia do Ensino Superior e Docência no Ensino Superior conforme as regiões do Brasil

Tabela 4 - Programas de pós-graduação e Cursos de pós-graduação no Brasil registrados em 2018 . .46

Tabela 5 - Resultado da análise de dissertações e teses do BDTD de 2012-2017 60

Tabela 6 - Dissertações e Teses analisadas distribuídas por ano; região do país. .60

Tabela 7 - Desenvolvimento em número dos cursos de Educação Física presencial e a distância de 2007-2017

Tabela 8 - Dados Gerais dos Cursos de Graduação Presenciais e a Distância de Educação Física - Brasil - 2016 e 2017 . .86

Tabela 9 - Número de Concluintes dos cursos presenciais e a distância da categoria de Saúde e Bem-Estar Social com mais de 10.000 formandos . .87

Tabela 10 - Programas de Pós-Graduação stricto sensu em funcionamento de acordo com área de avaliação da Educação Física 100

Tabela 11 - Ano de inserção na IES e número de doutores 137

Tabela 12 - Produção do conhecimento da Professora Larissa em sua trajetória acadêmica e profissional

Tabela 13 - Produção do conhecimento do Professor Felipe em sua trajetória acadêmica e profissional .144

Tabela 14 - Produção do conhecimento do Professor Eriberto em sua trajetória acadêmica e profissional

Tabela 15 - Produção do conhecimento do Professor Abel em sua trajetória acadêmica e profissional 


\section{LISTA DE SIGLAS}

BDTD Base De Dados A Biblioteca Digital De Teses E Dissertações

CAPES Coordenação de Aperfeiçoamento de Pessoal de Nível Superior

CBAt Confederação Brasileira de Atletismo

CBBd Confederação Brasileira de Badminton

CELAFISC Centro de estudos do laboratório de aptidão física de São Caetano do Sul

CEP Comitê de Ética de Pesquisa com Seres Humanos

CFE Conselho Federal de Educação

CI Conceito institucional

CNPQ Conselho Nacional de Desenvolvimento Científico e Tecnológico

CONFEF Conselho Federal de Educação Física

COPERVE Comissão Permanente de Vestibular

DNCs Diretrizes Nacionais Curriculares

$\mathrm{EaD} \quad$ Educação a Distância

EMEC Sistema Eletrônico do Ministério da Educação

FA Fundação Araucária

FAPEU Fundação de Amparo à Pesquisa e Extensão Universitária

FAPs $\quad$ Fundações Estaduais de Apoio à Pesquisa

FEUSP $\quad$ Faculdade de Educação da Universidade de São Paulo

FHGb Federação Gaúcha de Handebol

FINEP Financiadora de Estudos e Projetos

IAT

Coordenação de Desenvolvimento do Ensino Superior do Instituto Anísio Teixeira

CI Conceito Institucional

IGC Índice Geral De Cursos

INEP Instituto Nacional de Estudos e Pesquisas Educacionais Anísio Teixeira

LAEF Laboratório de Esforço Físico

LDB Lei de Diretrizes e Bases da Educação Nacional

ME Ministério do Esporte

MEC Ministério de Educação

PCC Práticas como Componente Curricular 
PET-SAÚDE Programa de Educação pelo Trabalho para a Saúde

PNE Plano Nacional de Educação

PNPG Plano Nacional de Pós-Graduação

PRODEGESP Pró-reitora de Desenvolvimento e Gestão de Pessoas

REUNI Reestruturação e Expansão das Universidades Federais.

SNPG Sistema Nacional de Pós-Graduação

SUDEB Superintendência de Desenvolvimento da Educação Básica

SUS Sistema Único de Saúde

TICS Tecnologias de Informações e Comunicações

UAB Universidade Aberta

UESC Universidade Estadual de Santa Cruz

UFAM Universidade Federal do Amazonas

UPC Universidade Pública Catarinense

UPP Universidade Pública do Paraná

UPRC Universidade Pública de Rio Claro

UPRS Universidade Pública do Rio Grande do Sul

USP Universidade de São Paulo 
INTRODUÇÃ

CAPÍTULO 1 - DOCÊNCIA UNIVERSITÁRIA: FORMAÇÃo E A PRÁTICA

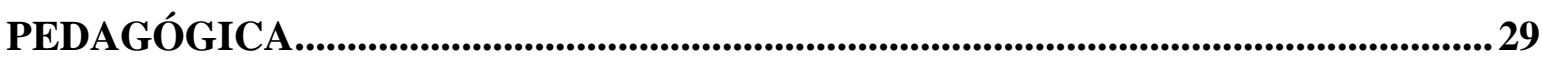

1.1 CONTEXTUALIZANDO A DOCÊNCIA UNIVERSITÁRIA …………………...........29

1.2 FORMAÇÃO DE PROFESSORES UNIVERSITÁRIOS ..............................................35

1.3 PRÁTICA PEDAGÓGICA NA DOCÊNCIA UNIVERSITÁRIA: estado da arte ........56

CAPÍTULO 2 - EDUCAÇÃO FÍSICA: PROFISSÃO E PROFISSIONALIZAÇÃO.68

2.1 O CURRÍCULO E AS FORMAÇÕES INICIAIS EM EDUCAÇÃO FÍSICA .............68

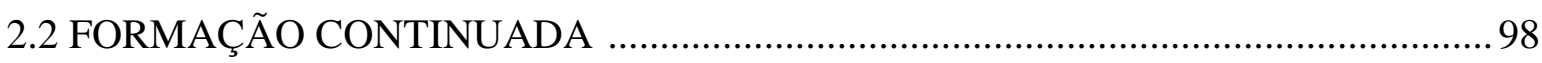

CAPÍTULO 3 - ONSTRUÇÃO DAS IDENTIDADES DOS PROFESSORES UNIVERSITÁRIOS ...............................................................................................108

CAPÍTULO 4 - CAMINHO METODOLÓGICO..............................................................133

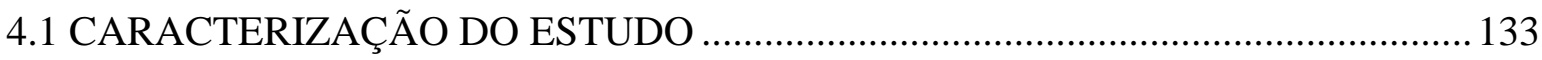

4.2 CONTEXTO E PARTICIPANTES DO ESTUDO ………………….................... 134

4.2.1 Seleção Dos Participantes ................................................................................................136

4.2.2 Perfil Dos Participantes......................................................................................................137

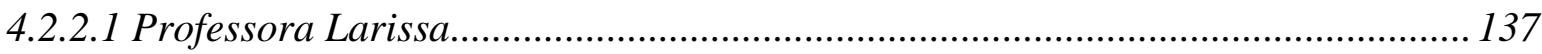

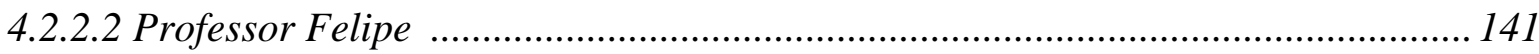

4.2.2.3 Professor Eriberto ………………………………………………………. 145

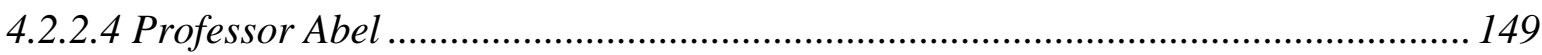

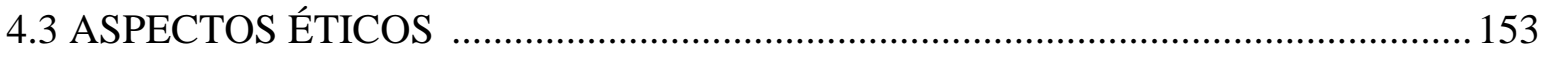

4.4 INSTRUMENTOS E PROCEDIMENTOS DE COLETAS DE DADOS ..................153

4.4.1 Documentos ............................................................................................................................153

4.4.2 Entrevista .................................................................................................................154

4.4.3 Observação ................................................................................................................155

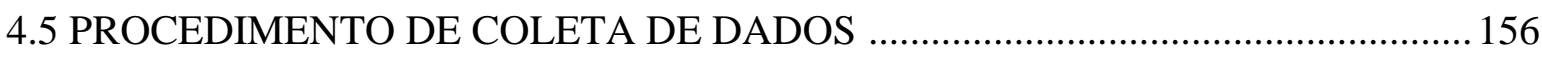

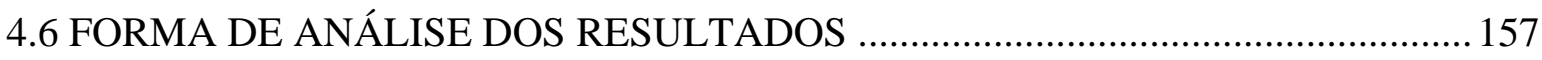

CAPÍTULO 5 - HISTÓRIA DE VIDA DOS PROFESSORES UNIVERSITÁRIOS DE EDUCAÇÃO FÍSICA JOVENS DOUTORES: CONSTRUÇÃO DA IDENTIDADE 158

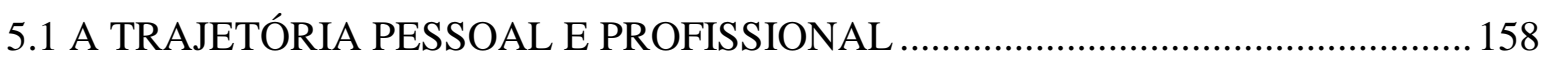


5.2 A CONSTRUÇÃO DAS IDENTIDADES DOS PROFESSORES JOVENS DOUTORES 188

CAPÍtulo 6 - A CONSTRUÇÃO dA PRÁticA PEDAGÓGICA DOS PROFESSORES DE EDUCAÇÃO FÍSICA JOVENS DOUTORES 199

6.1 ORGANIZAÇÃO E DESENVOLVIMENTO DAS PRÁTICAS PEDAGÓGICAS ...199 CONSIDERAÇÕES FINAIS .236

REFERÊNCIAS .239

ANEXOS. .258

APÊNDICES .267 


\section{INTRODUÇÃO}

Esta pesquisa de cunho qualitativo do tipo exploratório e documental tem como objeto de estudo a prática pedagógica dos professores universitários de Educação Física jovens doutores. A fim de compreender a escolha deste objeto e em específico por esta temática se faz-se necessário rememorar a minha história de vida e como ela se encontra imbricada com a formação de professores de Educação Física, bem como as contribuições da socialização primária e secundária para a prática pedagógica docente.

Ao escrever e/ou explanar sobre a própria história de vida, as pessoas precisam resgatar da memória lembranças do passado. A memória foi uma das principais ferramentas neste estudo desde o surgimento da temática até compreender a construção da prática pedagógica dos professores universitários. A autora Angelo (2016) discorre ao longo de seu texto sobre a história oral e a história da memória, e discute a relação da memória a partir de duas perspectivas: a primeira está associada a formação individual e pode ser a fonte de referência da identidade - fundamentado em Bergson e Candau. Enquanto a segunda considera que há interação entre a memória individual e memória coletiva, norteada pelos autores Halbwachs, Ricoeur e Pollack.

Ao longo da prática docente sou desafiada constantemente por questões, e para solucioná-las sempre sou surpreendida com recordações das experiências passadas ocorridas a partir da socialização primária e secundária, isto é, no meio social (família, escola etc.) e profissional. Esse exercício de reconstituição da memória ao longo da prática inicialmente veio espontaneamente pela necessidade de alcançar uma solução. Com o passar o tempo, comecei a ter consciência da importância desse processo, mas confesso que isso obtive auxílio dos meus familiares, pois sabia de algo, mas não me lembrava como aquilo fazia parte de mim.

Embora esse exercício de reconstituição da memória seja difícil, permitiu-me identificar o reflexo das experiências do passado no meu eu pessoal e profissional de hoje, principalmente nas minhas tomadas de decisões ao longo da minha prática docente. Em virtude disso, surge a curiosidade de compreender a construção da prática pedagógica dos meus pares, pois estou atuando no Ensino Superior há quatro anos, e percebi a necessidade de entender o ser humano a partir de suas diferentes culturas e perspectivas. Ou seja, não bastavam os conhecimentos adquiridos ao longo da minha formação acadêmica, relacionado ao conhecimento pedagógico e técnico-científico: como construir um projeto, um plano de aula etc. Eu precisava olhar para os meus alunos como um ser constituído por diversas 
experiências, que muitas transcendem meus valores, e como lidar com isso? O que falar e agir uma aluna diz na véspera da coleta de dado do Trabalho de Conclusão de Curso - TCC: “professora estou grávida, e agora?”, depois de duas semanas, entra na minha sala e diz: “professora perdi meu bebê (e chora)!". Vou além, abro meu celular e vejo uma mensagem de voz de cinco minutos, desculpando-se sobre sua ausência, mas tinha tentado se suicidar e o motivo estava relacionado ao abuso sexual e à dependência química, mas pediu para jurar não contar a ninguém muito menos aos seus pais.

Outra situação marcante foi quando assumi o componente curricular - Trabalho de Conclusão de Curso - TCC I, e descubro que, em uma turma de 12 estudantes, três apresentavam o diagnóstico de depressão. Como ministrar a disciplina mais temida entre os acadêmicos, sabendo que os estudantes de Educação Física apreciam mais a prática ao invés das atividades teóricas? como chegar a esses estudantes e mostrar que não é o fantasma que todos apontam e que apresentam competências para tal?

Em todos esses momentos, meu conhecimento e experiências acadêmicas foram de extrema valia, mas confesso, valeu-me minha socialização primária, a qual consolidou meus valores e minha espiritualidade bem trabalhada. Caso contrário, esses estudantes passariam a ser mais um cliente, haja vista que atuo numa instituição privada.

Por esse motivo considero que a prática pedagógica docente vai além dos conhecimentos adquiridos ao longo da formação acadêmica e de sua socialização profissional. A final, o que aconteceu em minha socialização primária que me levou a obter essa percepção?

Nasci no município de Joinville-SC, cidade em que resido atualmente, juntamente com minha mãe. Sou filha de pais divorciados desde 1995, entretanto meu pai também reside em Joinville-SC. Sou a terceira filha do casal, de origem de Ponta Grossa - PR, que teve mais dois filhos, ambos já falecidos no ano de 1996. Em 1997, meu pai casou-se novamente e teve uma filha dessa segunda união.

Em virtude de percalços ocorridos, minha mãe e eu mudamo-nos para o apartamento de uma amiga, no centro da cidade, pois éramos apenas eu e ela, não podíamos contar com ninguém mais para me levar e buscar da escola, precisava desenvolver minha autonomia. Assim, mudei para um colégio de rede privada, mantido pela Sociedade Divina Providência (anteriormente estudava numa escola pública), no qual realizei o Ensino Fundamental ( $5^{\mathrm{a}}$ a $8^{\text {a }}$ série) e o Ensino Médio noutra escola privada.

As mudanças permitiram-me realizar sozinha o deslocamento ao colégio e as atividades extraclasse, pois minha mãe trabalhava das 10 horas às 17 horas e cursava a 
graduação em Física, em uma universidade pública, e não podia me auxiliar com as tarefas. Com dez anos de idade, precisei tomar as rédeas das tarefas diárias, deveria saber os horários das atividades cotidianas e até mesmo da minha alimentação, o que contribuiu para o desenvolvimento da minha identidade pessoal, permitiu que aprendesse a não depender do outro para o desenvolvimento de tarefas, as quais eram minhas, logo, deveria realizá-las, bem como cumprir os horários e organizar meus materiais e roupas.

Tais situações tornaram-me mais autônoma e responsável pelas minhas atitudes, não poderia "culpar ninguém", e sabia que se fizesse algo errado deixaria minha mãe chateada e talvez iria expô-la mais junto à comunidade. Isso não poderia acontecer em nenhum momento, pois já sofrera demais com suas perdas e o julgamento das pessoas sobre os ocorridos.

Nesse período escolar realizei atividades extracurriculares: participei do grupo escoteiro; realizei aulas de teclado, bem como formação completa em teoria musical; aulas de inglês; pratiquei voleibol na equipe da escola onde estudava, participando de diversos campeonatos municipais. Fui bailarina no estilo de dança de rua, sendo premiada em distintos festivais de dança no país (Joinville; Rio de Janeiro; Porto Alegre; Salete etc.). Tais atividades também contribuíram de forma significativa para minha construção identitária, principalmente as questões de vivências em grupo, deveres e regras a serem cumpridos, respeito ao próximo, independente de quem seja, e sensibilidade para a arte e cultura. Permitiram-me adquirir valores humanos fundamentados no respeito, ética, responsabilidade, solidariedade, humildade, cooperação, tolerância, lealdade e liberdade.

Outro fator de destaque nesse percurso ocorreu em 1998, quando minha mãe iniciou a faculdade de Física. O convívio com os hábitos de estudos de minha mãe, juntamente com seus colegas, permitiu-me desenvolver o mesmo hábito. Inicialmente, todas as atividades extraclasse eram mais interessantes, mas, com o passar do tempo, fui percebendo a importância do estudo, bem como o gosto pela busca do conhecimento.

Além dessa contribuição, no meu convívio social estiveram sempre presentes pessoas que atuavam na docência ou que estavam estudando para serem professores, por isso identifiquei-me com a profissão, além da minha característica altruísta de ajudar ao próximo, acabei escolhendo realizar o curso de Licenciatura. Confesso que, inicialmente, as duas perspectivas que norteiam os cursos de Educação Física - área da saúde e Educação - me confundiram. Pensei na formação em Educação Física, que me permitiria atuar nos dois espaços, mas ainda tinha algo que me incomodava, pois sempre gostei muito da área das exatas, principalmente de química e matemática. Então realizei os vestibulares, com a 
primeira opção em Educação Física e colocando como segunda opção química, mas prevaleceu a primeira.

As vivências apresentadas ao longo desse breve relato sobre a trajetória pessoal permitiram refletir sobre minha identidade pessoal e social. Essas reflexões contribuem para minha atual identidade profissional, principalmente no que concerne aos motivos de escolha pela formação inicial em Educação Física e olhar os estudantes como seres humanos compostos por uma história, a qual se precisa respeitar e suas experiências refletem em suas tomadas de decisões e na sua aprendizagem. Realmente vivenciei isso, mas precisei de terapia, de amigos, do esporte, da arte - dança e música - da família, dos professores e do suporte religioso para me tornar a pessoa que sou hoje. Nunca fui a melhor aluna da classe, sempre precisava estudar mais que meus colegas, confesso que, às vezes pensava: "oh Deus por que tudo para mim é tão difícil?". Entretanto, todas as experiências vividas e pessoas que passaram ao longo do meu caminho me ensinaram que não poderia desistir, as dores e as dificuldades elas vêm, mas elas também passam.

Percebi que as pessoas precisam umas das outras, cada um reage de uma forma e aprende no seu tempo e espaço. Sentir a interferência das situações em sua aprendizagem e convívio social, além disso, superar os monstros que lhes assombram, é diferente do que ler um livro e/ou um artigo sobre o assunto e dizer que conhece ou sabe o que as pessoas sentem.

Colocar-se no lugar do outro é uma tarefa árdua, pois cada ser é único, devido suas distintas experiências. E para que isto ocorra precisa-se de sensibilidade para compreender o outro, isso se dá pelas vivências e valores humanos atribuídos, principalmente, em sua socialização primária.

Reconheço também que a socialização secundária contribui constantemente para minha prática pedagógica, mas isso percebi apenas quando realizei a pesquisa sobre esse tema com meus antigos professores da graduação. Tal experiência me fez tomar consciência de como minhas atitudes e hábitos profissionais eram semelhantes aos deles, bem como as perspectivas, os valores e as crenças. Além do mais, esta investigação me permitiu compreender o outro e suas tomadas de decisões, pois consegui identificar com maior robustez a cultura do outro, as perspectivas, os valores, as crenças e as expectativas.

Posso afirmar, sem medo de errar, minhas experiências pessoais e profissionais me fizeram e me fazem constantemente refletir sobre minha atuação profissional, pois ao transitar na área educacional, esportiva e da saúde, tomei consciência de que o docente precisa reconhecer que todos os momentos da sua vida como situações de aprendizagem sejam elas: formais, não formais e informais. Se o docente não reconhecer, principalmente 
os espaços informais como oportunidade de aprendizagem, ficará restrito às teorias e experiências do outro, dificultando a construção e reconstrução da sua própria identidade.

[...] a construção da identidade do professor não pode e não deve ser considerada somente a partir de seus conhecimentos adquiridos ao longo dos anos, em sala de aula, como aluno. Mas, também, através de toda uma história de vida, que carrega consigo uma carga de experiência familiar, social, cultural, religiosa, econômica e a própria inserção na carreira docente, em seus primeiros anos de atividades, com seus anseios, conflitos e dificuldades enfrentadas na sala de aula (TENROLLER et al., 2011, p. 03).

A minha socialização primária e a secundária auxiliam na construção e reconstrução identitária docente, além disso conduzem minha prática pedagógica na Educação Básica e no Ensino Superior, consequentemente me instigaram a investigar o objeto de pesquisa em questão. Dessa forma, este estudo tem como base que a prática pedagógica: "são práticas sociais que se organizam para dar conta de determinadas expectativas educacionais de um grupo social [...] funcionam como espaço de diálogo: ressonância e reverberação das mediações entre sociedade e sala de aula" (FRANCO, 2012, p. 180).

A escolha pelos jovens doutores, veio devido a três motivos: primeiro, pois é uma realidade que vou encontrar após a finalização dessa formação, fruto deste trabalho, consequentemente me auxiliará refletir sobre minha prática. $\mathrm{O}$ segundo fator contribuinte foi identificar que uma Instituição do Ensino Superior - IES de Santa Catarina estava passando por um movimento de renovação do quadro docente, com o ingresso de um número significativo de professores jovens doutores nos cursos de Educação Física. O terceiro motivo está relacionado ao cenário que vem se apresentando na literatura sobre a formação pedagógica do professor universitário, há questionamentos sobre: como e onde está correndo, bem como de quem é responsabilidade.

Segundo a Lei de Diretrizes e Bases da Educação - LDB de 1996 os programas de pós-graduação (mestrado e doutorado) devem formar docentes para o Ensino Superior, as ações desenvolvidas envolvem o estágio de monitoria/docência na formação inicial e a oferta de disciplinas relacionadas ao ensino e formação pedagógica. Além disso, vem associando essas ações junto à regulamentação das bolsas de estudos, colocando como critérios aos contemplados o envolvimento em atividades pedagógicas (PIMENTA; ANASTASIOU, 2010).

Tais ações podem ser resultado do Programa de Apoio a Planos de Reestruturação e Expansão das Universidades Federais (REUNI), iniciada em 2003 e finalizada em 2012, cujo objetivo foi criar " $[\ldots]$ condições para que as universidades federais promovam a expansão 
física, acadêmica e pedagógica da rede federal de educação superior” (REUNI, 2010, s.p.). O REUNI foi dividido em seis dimensões, uma delas é: o suporte da pós-graduação ao desenvolvimento e aperfeiçoamento qualitativo dos cursos de graduação, incluindo a articulação da graduação com a pós-graduação: expansão qualitativa e quantitativa da pósgraduação orientada para a renovação pedagógica da Educação Superior (REUNI, 2010).

Ainda que se evidencie a existência dessas ações na pós-graduação, Isaia (2006) afirma que tais iniciativas não contribuem de forma efetiva para as atribuições da docência no Ensino Superior, com o fato de formar futuros profissionais. Pereira e Medeiros (2011) apontam que o estágio não apresenta espaço de discussão sobre os procedimentos didáticopedagógicos para atuação docente, mas é um dos principais momentos que aproximam os estudantes da pós-graduação da docência do Ensino Superior. Esses autores ao investigarem 22 cursos de pós-graduação em Educação Física, puderam identificar que todos possibilitam o estágio de docência e sete oferecem a disciplina de Metodologia do Ensino Superior em suas atividades curriculares. A implantação mais antiga dessa disciplina foi no ano de 2006, isso é, nos últimos doze anos os cursos de pós-graduação em Educação Física vêm se preocupando em oferecer disciplina que aproxime seu estudante da docência do Ensino Superior.

Essas ações, estágio de docência e disciplinas de cunho didático-pedagógico são recursos de aproximação da docência no Ensino Superior, mas também não se pode considerá-las como aspectos determinantes para atuar nesse contexto. Assim, o presente estudo compartilha da mesma perspectiva apontada por Isaia (2006, p.23):

[...] a docência superior é um processo complexo que se constrói ao longo da trajetória docente e que esta envolve, de forma intrinsecamente relacionada, a dimensão pessoal, a profissional e a institucional. Na tessitura das três, dá-se a constituição do ser professor. [...] professor é um ser unitário, entretecido pelo percurso pessoal (ciclo vital), pelo profissional (os vários caminhos construídos pela profissão) e pelo institucional (os diversos contextos em que atua ou atuou).

Em virtude do exposto, o interesse investigativo à presente tese aqui defendida é: os professores universitários de cursos de Educação Física, jovens doutores, constroem e desenvolvem suas práticas pedagógicas a partir de processos subjetivos que são mediados pelo estigma da profissão e pelos conhecimentos construídos seja na formação inicial ou na vivência como estudantes, além das experiências profissionais. Assim norteada pelo seguinte objetivo principal: investigar o processo de construção da prática pedagógica de docentes da Educação Física, jovens doutores, a partir dos processos subjetivos e objetivos da formação 
pessoal e profissional. Tal propósito dispõe de suas especificidades como: reconhecer a identidade real e a identidade virtual dos docentes; identificar e compreender a construção e o desenvolvimento das práticas pedagógicas dos professores dos cursos de Educação Física; averiguar as implicações das construções biográficas e subjetivas na consolidação da prática pedagógica.

Tal proposta apresentou como suporte teórico para a construção das identidades Goffman (1988) e Dubar (2005), como elemento basilar para compreender a docência no Ensino Superior e a prática pedagógica utilizaram-se os seguintes autores: Miguel Zabalza, Selma Anastasiou, Maria Isabel de Almeida, Ilma Veiga, Maria Amélia do Rosario Santoro Franco e Marisa Isabel da Cunha. Além desses em destaque, houve outros autores abordados nesta pesquisa, pois compartilham de perspectivas semelhantes à discutida neste estudo. Esta tese foi organizada em seis capítulos, cuja apresentação e desdobramentos por assuntos seguem:

Capítulo 1 - Docência universitária: formação e a prática pedagógica - discute os aspectos históricos e ações formativas para docência nos cursos de pós-graduação lato sensu e stricto sensu, bem como sobre a docência na universidade sua complexidade e o papel do professor. Além disso, apontaram-se os conceitos, as perspectivas teóricas e as discussões científicas sobre a prática pedagógica.

Capítulo 2 - Educação Física: profissão e profissionalização - aborda sobre o currículo quanto às teorias e o surgimento e crescimento dos cursos de formação inicial em Educação Física. Em seguida discutimos sobre a formação continuada de acordo com a pósgraduação lato sensu e stricto sensu, cursos e programas de aperfeiçoamento e demais modalidades

Capítulo 3 - Construção das identidades dos professores universitários fundamenta-se nas abordagens teóricas de Goffman (1988) e Dubar (2005), discutindo concomitantemente com os modelos de identidades sobre o docente a partir de Alves et al. (2007) e Pagnez (2007). Além disso, utilizamos estudos que abordam sobre essa temática na área da Educação Física.

Capítulo 4 - Caminho Metodológico - abordou o método e tipo de pesquisa; contexto e o público-alvo do estudo; instrumento de coleta de informações; como procedemos a pesquisa; os procedimentos éticos; como foram analisados os dados encontrados.

Capítulo 5 - História de vida dos professores universitários de Educação Física jovens doutores: construção da identidade - retrata a trajetória pessoal e profissional dos 
participantes investigados e como ocorreu a construção das suas identidades a partir dos modelos teóricos que fundamentam este estudo.

Capítulo 6 - A construção da prática pedagógica dos professores de Educação Física jovens doutores - apresentou como são organizadas e desenvolvidas as práticas pedagógicas dos professores jovens doutores, bem como as contribuições trazidas das trajetórias pessoais e profissionais. 


\section{CAPÍTULO 1 \\ DOCÊNCIA UNIVERSITÁRIA: FORMAÇÃO E A PRÁTICA PEDAGÓGICA}

Este capítulo traz uma discussão a respeito da docência universitária, a formação de professores para o Ensino Superior e a sua prática pedagógica. Na primeira parte serão apresentados aspectos históricos, tendo como eixo central a legislação vigente para a formação docente, como também um retrato histórico e atualizado dos cursos e programas de pós-graduação no país. Além das ações formativas que contemplam a docência, especificamente a prática pedagógica, apresentar-se-á um esboço sobre essa prática.

\subsection{CONTEXTUALIZANDO A DOCÊNCIA UNIVERSITÁRIA}

A docência universitária necessita uma formação profissional, que proporcione a aquisição de conhecimentos específicos da área, bem como conhecimentos e habilidades associados à atividade docente (ZABALZA, 2004; VEIGA, 2006; MASETTO, 2015a). Exige distintos saberes, apropriados e entendidos de acordo com as relações estabelecidas entre eles, a docência é uma atividade complexa e exige compreensão de sua totalidade. Consideramos que o professor em sua atuação necessita contribuir na aprendizagem do estudante para a busca e a construção do conhecimento e não somente na transmissão do conteúdo (CUNHA, 2010; SOARES; CUNHA, 2010).

A atividade docente, em qualquer grau, está relacionada à ação educadora (FREIRE, 2008), no entanto, atualmente, está marcadamente reduzida a procedimentos técnicos fundados no imediatismo, advindos da revolução das tecnologias de informação e comunicação (TICs), as quais estão afetando diretamente o Ensino Superior, quanto às perspectivas sobre a construção e socialização do conhecimento, à valorização do processo de aprendizagem e à formação de profissionais competentes e cidadãos (MASETTO, 2014). Embora o acesso ao conhecimento esteja em diversos lugares (livros, documentos, internet, artigos etc.), não substitui a presença significativa do docente que contribui na decodificação, assimilação e aproveitamento das informações advindas desses locais, além da associação da prática profissional (ZABALZA, 2004).

A docência universitária está relacionada ao tripé - ensino, pesquisa e extensão - que envolve atividade reflexiva e problematizadora (VEIGA, 2006). Quando nos referimos às universidades públicas acrescenta-se como demanda aos docentes a gestão que envolve desde coordenação de cursos a cargos de pró-reitorias e reitorias (ZABALZA, 2004; GAETA; 
MASETTO, 2013). Isso resulta da ideia de que os professores são incumbidos de atribuições referentes à captação de financiamento, assessorias, estabelecimentos de relações institucionais com outras universidades nacionais e internacionais (ZABALZA, 2004).

O docente universitário é um profissional que desenvolve serviço para a comunidade a partir da instituição a que está vinculado (universidade), contribuindo para o desenvolvimento da aprendizagem dos estudantes e da sociedade (BENEDITO; FERRER; FERRERES, 1995). Em virtude disso, compreendemos o professor a partir de três dimensões: profissional, pessoal e laboral (ZABALZA, 2004). Corroborando com essa perspectiva, Isaia (2006) inclui a dimensão institucional na trajetória profissional, isto é, compreende o professor como um ser único, sustentado pelo seu percurso pessoal (ciclo vital), percurso profissional (experiências e conhecimentos construídos na profissão) e pelo percurso institucional (distintos contextos atuantes).

A dimensão pessoal caminha pela perspectiva da unificação entre pessoa/professor, marcada pelos processos de subjetivação/objetivação de acordo com cada docente, pois incorpora o mundo pedagógico no seu mundo pessoal (ISAIA, 2006). Para as autoras Isaia e Bolzan (2009, p. 132):

[...] o percurso docente como um processo complexo em que fases da vida e da profissão se entrelaçam, envolvendo movimentos de crises, recuos, avanços, descontinuidades e relativa estabilidade, representativos das mudanças ocorridas e que, portanto, não se apresenta de forma linear e generalizável a todos os professores, mantendo, assim um caráter idiossincrático.

Em virtude desse entrelaçamento, deixamos de olhar para o professor na condição de pessoa, focalizando apenas o profissional. Sabemos, entretanto, que a qualidade da função docente está associada às suas expectativas, crenças e valores, visto que o docente ensina o que sabe, além de ensinar o que ele é (ZABALZA, 2004). A formação da pessoa/professor está associada ao seu desenvolvimento pessoal no tempo, espaço e estilo de vida, seja em termos individuais ou grupais (ISAIA, 2001).

A dimensão profissional está associada às exigências e dilemas que envolvem a docência, como e quais parâmetros norteiam a identidade do professor e quais as necessidades da formação inicial e permanente quanto às exigências da profissão. Sabemos que o professor atuante na universidade não tem o papel apenas de ensinar, sua função docente está imbricada a tantas outras atribuições (pesquisa, extensão e gestão). À luz disso, os autores Benedito, Ferrer e Ferreres (1995) especificam as funções que contornam a docência universitária, a partir dos seguintes itens: a) o estudo e a investigação; b) a docência 
e sua organização, além do aperfeiçoamento de ambas; c) a comunicação (publicação) de suas pesquisas; d) a inovação e a comunicação das inovações pedagógicas; e) orientação e avaliação dos alunos; f) a participação responsável na seleção de outros professores; g) a avaliação da docência e da investigação; h) a participação na gestão acadêmica; i) a possibilidade de estabelecer a relação com o mundo do trabalho, da cultura etc.; j) a promoção e a troca entre os outros departamentos e universidades; k) e a contribuição para um clima de colaboração entre os professores. Além disso, Soares e Cunha (2010) apontam que a docência está voltada ao processo de aprendizagem e sua complexidade, levando a obter:

a) Um caráter interativo, pois o processo formativo ocorre simultaneamente com distintas pessoas e com suas histórias de vida particularizadas, induzindo o professor ao desafio de compreender todo esse processo de modo a orientar os estudantes de acordo com seus valores e atitudes. A aula torna-se um espaço de princípios educativos, assumindo a construção do conhecimento, bem como formação de cidadãos profissionais reflexivos, críticos e solidários;

b) Um caráter específico no processo de aprendizagem de estudantes adultos quanto a sua trajetória profissional, pois os conteúdos e objetivos de ensino precisam fazer sentido quanto ao seu papel social. Além disso, precisa contribuir na solução de situações-problema e aproximação dos conteúdos com a prática profissional;

c) Um caráter de conexão de conhecimentos, subjetividades e culturas, considerado um espaço de formação profissional, que permeia os conteúdos científicos, tecnológicos e até mesmo os artísticos. Assim, far-se-á o docente obter conhecimento da profissão numa perspectiva ampla, ainda que possibilite ao estudante a compreensão e articulação da teoria e da prática, a fim de desenvolvê-las para a transformação social.

Em suma, o docente necessita do conhecimento do conteúdo e da atividade, saber como aprende o estudante para orientá-lo, manejar de forma adequada os recursos de ensino e utilizá-los conforme a realidade trabalhada. Para o desenvolvimento de tal função, Zabalza (2004) considera fundamental a exigência intelectual e destrezas da prática baseadas em saberes. A primeira está relacionada ao docente quanto à necessidade de analisar e resolver problemas; analisar um tópico ou assunto, entendê-lo em sua essência e depois fazê-lo compreensível; apreciar os conteúdos e verificar a melhor forma de abordá-los; selecionar as estratégias metodológicas adequadas, além dos recursos que possibilitem a aprendizagem dos estudantes de forma adequada; e organizar as ideias, informações e tarefas para os estudantes. 
A segunda compreende que o docente precisa saber: identificar os conhecimentos já adquiridos pelos estudantes; estabelecer uma boa comunicação com os estudantes de forma individual e coletiva; e estimular os estudantes a aprender e trabalhar em grupo.

A docência, de modo geral, seja na Educação Básica, Ensino Profissionalizante e no Ensino Superior, vai além do ato de estar à frente dos estudantes, transmitindo o conteúdo pré-determinado no plano de ensino da disciplina. Ela exige do professor um ato de reflexão sobre todo o processo de ensino, bem como das características e necessidades de aprendizagem dos estudantes.

O professor do Ensino Superior precisa conhecer e compreender a comunidade em que está inserido, a partir disso, ao longo de suas aulas, aproximará o conteúdo abordado em sala com a realidade vivida. Desse modo dará sentido ao conhecimento que se está construindo, o docente precisa ir além do conhecimento específico do conteúdo ao longo do desenvolvimento de suas aulas, precisa adentrar de forma profunda nos aspectos fundamentais para formação de profissionais.

Por exemplo, num curso de Licenciatura, os estudantes aprendem a trabalhar apenas com materiais digitais, vislumbrando o uso de celulares, tablets e computadores em sala de aula, haja vista que vivemos a era digital. Na comunidade em que estão inseridos, entretanto, há duas instituições particulares e as demais públicas, que não dispõem de recurso financeiro para se apropriar de materiais digitais. No momento em que estudantes se aproximam da prática profissional, a partir dos estágios, inicia o choque com a realidade, apresentando o sentimento de ausência de conhecimento e despreparo para atuarem na área educacional.

Percebemos que foi um exemplo simples, mas real, pois reflete a necessidade do professor do Ensino Superior conhecer a realidade na qual vive e está formando profissionais. Não adianta formar profissionais sonhadores e ludibriados com os materiais digitais existentes e que estão substituindo jogos de tabuleiros, brinquedos, caderno etc., realidade existente em algumas escolas particulares. No entanto, atualmente, muitas escolas vêm se utilizando de materiais não estruturados, muitos designam como materiais reciclados, os quais são doados pela comunidade para que os professores consigam desenvolver atividades e brinquedos para as crianças.

Logo, a formação de profissionais precisa acompanhar o desenvolvimento da sociedade, sim, mas também requer sensibilidade para captar as necessidades almejadas pela comunidade. Desse modo evitam-se frustrações e atuações errôneas dos jovens profissionais.

Freire (2008) considera que a real missão da universidade brasileira se fará no momento em que os professores assumirem papel de educadores e não transmissores de 
conteúdo. Esse pensamento abandona a cultura de transferência de fórmulas, passando a ser um espaço de formação de atitudes, fundada no conhecimento crítico das situaçõesproblema. O professor universitário passa a ser um educador lúcido, responsável e humilde. Isto é, o docente precisa reconstruir sua identidade profissional a partir das mudanças de perspectivas por meio de novos conhecimentos, possibilitando alterações, como aborda Freire (2008), dessa forma interferindo significativamente na própria prática docente.

Zabalza (2004), entretanto, aponta que a identidade do docente universitário se constitui e reconstitui a partir de dilemas enfrentados pelos professores universitários como:

- Individualismo/Coordenação - o professor, ao longo da sua carreira, desenvolve o individualismo de forma significativa, o que dificulta a ação de coordenação;

- Investigação/Docência - a predominância formativa do professor universitário está impregnada na pesquisa, ofuscando os aspectos da docência enquanto ensino. Considera como fatores predominantes para a qualidade do ensino na universidade a dialética investigação-docência e seu impacto no desenvolvimento pessoal e profissional do docente;

- Generalista/Especialista - o professor se especializa num determinado assunto, levando a fragmentação do conhecimento aos alunos. É importante, entretanto, que haja equilíbrio, pois o professor também necessita de conhecimentos gerais para orientar os estudantes para que ocorra a formação integral;

- Ensino/Aprendizagem - o professor universitário está preocupado em ensinar o conteúdo, no entanto despreza a aprendizagem do estudante, ou seja, não se preocupa com a construção do conhecimento e de sua compreensão.

Os dilemas apontados sintetizam a identidade profissional atribuída a muitos professores universitários, pois caracterizam a profissionalidade docente, bem como a acentuada presença da formação inicial (ZABALZA, 2004). Isaia (2006) aponta que essa identidade inicia na escolha da profissão, perpassando pela formação inicial e espaços de experiências profissionais. Além disso, também contribuem para a constituição do professor:

[...] as ações autoformativas, heteroformativas e interformativas, desenvolvidas pelos docentes em suas relações interpessoais, que envolvem alunos, colegas e também abarcam o contexto universitário em que estão inseridos e a comunidade para a qual eles têm a responsabilidade social de contribuir. No tripé da universidade, ensino, pesquisa e extensão, estão contempladas as diversas ações formativas necessárias ao processo constitutivo de ser professor (ISAIA, 2006, p. 72-73). 
Em virtude disso, percebemos que as instituições onde os professores estão vinculados também contribuem para a construção da identidade profissional. Logo, as questões sobre a dimensão laboral ou institucional mencionada por Zabalza (2004) e Isaia (2006) também se fazem importantes, caso a discussão gire em torno da docência universitária, ainda mais sobre o professor. As questões que os norteiam são: as políticas de seleção e critérios que se aplicam; características diferenciais dos diversos contratos e categorias de professores; e condições do funcionário público atribuída à maior parte dos professores (ZABALZA, 2004).

Sabemos que a realidade dos professores que atuam em universidades públicas e privadas é distinta, como: estrutura, forma de contratação, dedicação ao ensino, pesquisa e extensão, formação continuada dentre outros aspectos inerentes à instituição. Tais aspectos interferem significativamente no desenvolvimento profissional docente, isto é, contribui para a construção da identidade profissional e suas práticas docentes. Em virtude disso, é importante que os órgãos administrativos e as instituições considerem as necessidades e expectativas dos professores, a fim de favorecer as condições de trabalho, valorização docente e estabelecer políticas para a formação contínua e em exercícios (ISAIA, 2006).

Enfim, as instituições, ao longo do desenvolvimento profissional do professor, podem contribuir para a alteração da prática docente, as crenças e os conhecimentos profissionais (os aspectos informativos). O docente contribui para esse desenvolvimento a partir da necessidade do crescimento pessoal e profissional, reflexão de suas práticas de forma coletiva e individual, de suas atitudes e crenças, além de se possibilitar novos conhecimentos e mudanças (SOARES; CUNHA, 2010). Tudo isso está imbricado na docência universitária, é difícil olhá-la apenas nos aspectos de aprendizagem, pois, para que ocorra de forma adequada e de qualidade, é necessário olhar o professor como um todo no seu ambiente laboral, de forma que contribua de fato para o desenvolvimento da docência.

Este estudo considera, quanto aos aspectos normativos, que há contribuições significativas dos cursos de pós-graduação lato sensu e stricto sensu na docência universitária e para a formação da identidade profissional desses professores, principalmente no impacto sobre suas práticas pedagógicas. Além disso, as IES formadoras possuem um papel fundante na formação de seus professores, pois precisam promover formação continuada, a fim de auxiliá-los no cumprimento de suas funções. Também admitimos e compreendemos que as trajetórias pessoal e profissional dos docentes, a partir das experiências vividas, colaboram nos aspectos formativo e prático. Em virtude disso, este capítulo é composto por duas partes: a formação de professores universitários e a prática pedagógica na docência universitária. 


\subsection{FORMAÇÃO DE PROFESSORES UNIVERSITÁRIOS}

Este tópico versará sobre a formação do professor universitário, cuja responsabilidade cabe aos cursos de pós-graduação e sua formação continuada às universidades onde desenvolve a docência. Em detrimento dessa perspectiva, iniciar-se-á a discussão pela formação acadêmica (pós-graduação) sustentada pelo percurso histórico e a legislação brasileira, seguindo pelas formações desenvolvidas pelas IES.

O curso de pós-graduação no Brasil teve início por volta de 1930, com a contribuição de professores vindos da Europa, alguns em missão e apoiados pelo governo europeu. A assimetria pedagógica centrava no docente, o poder, que definia as questões e os métodos para dissertação, bem como as técnicas para pesquisa. A pós-graduação, nessa época, era apenas uma das alternativas para a inserção na vida acadêmica. Então, em 1961, a Lei no 4.024/61 - Lei de Diretrizes e Bases, apresentou definições de termos, aspectos históricos, necessidades e estruturação da pós-graduação, consolidada a partir do parecer no 977/65, denominado Parecer Sucupira (BALBACHEVSKY, 2009). Esse parecer contempla os aspectos inerentes aos cursos de mestrado e doutorado com mais propriedade, entretanto está sustentado pelas concepções descritas na LDB (BRASIL, 1961), principalmente, ao mencionar que o Ensino Superior, além da graduação, tem como responsabilidade ministrar a pós-graduação e a especialização, considerando:

a) de graduação, abertos à matrícula de candidatos que haja concluído o ciclo colegial ou equivalente, e obtido classificação em concurso de habilitação;

b) de pós-graduação, abertos à matrícula de candidatos que haja concluído o curso de graduação e obtido o respectivo diploma;

c) de especialização, aperfeiçoamento e extensão, ou quaisquer outros, a juízo do respectivo instituto de ensino abertos a candidatos com o preparo e os requisitos que vierem a ser exigidos (BRASIL, 1961, s.p).

O Parecer Sucupira enfatiza o conceito de pós-graduação, origem, abordagem descrita na LDB (BRASIL, 1965), estatuto do magistério, definição e características do mestrado e doutorado, bem como a necessidade da pós-graduação, assim destacando:

os três motivos fundamentais que exigem, de imediato, a instauração de sistema de cursos pós-graduados: 1) formar professorado competente que possa atender à expansão quantitativa do nosso ensino superior garantindo, ao mesmo tempo, a elevação dos atuais níveis de qualidade; 2) estimular o desenvolvimento da pesquisa científica por meio da preparação adequada de pesquisadores; 3) assegurar o treinamento eficaz de técnicos e trabalhadores intelectuais do mais alto padrão para fazer face às necessidades do desenvolvimento nacional em todos os setores (BRASIL, 1965, p.2). 
Além desses objetivos que contornaram a pós-graduação, sua estrutura foi organizada em cursos stricto sensu - mestrado e doutorado - cursos subsequentes à graduação, visando a objetivos amplos e aprofundados de formação científica ou cultural. E os cursos de especialização e aperfeiçoamento passaram a ser cursos lato sensu, associados a uma especificidade (BRASIL, 1965).

Ainda apontou características fundamentais para os cursos de pós-graduação, no que tange ao mestrado e doutorado. Enfatizando: a duração (mínimo um ano para o mestrado e dois para o doutorado); o pré-requisito para ingressar (candidatos que concluíram a graduação); deveres do mestrando e doutorando ao longo do curso e para sua finalização, dentre outras especificidades que normatizam a pós-graduação. Isto é, para ambos os cursos, o candidato precisava cumprir a carga horária total de 360 a 450 horas de trabalhos escolares, aulas, seminários ou atividades de laboratórios, por ano letivo. Especificamente, a primeira fase estava centrada mais nas aulas, seminários, dentre outros deveres, enquanto na segunda fase o pós-graduando deveria realizar a investigação de uma temática especial, resultando em sua dissertação ou tese (BRASIL, 1965).

Sabemos que o surgimento da pós-graduação no Brasil está associado à perspectiva de pesquisa, considerada a principal fonte de produção científica (DANTAS, 2004). No entanto o parecer n $977 / 65$ já fazia menção à formação para docência no Ensino Superior, primeiramente, se refere ao surgimento dos programas de pós-graduação no Brasil, os quais vêm ao encontro da qualificação do corpo docente para atuar nas universidades. De acordo com o caso, "aos candidatos ao doutorado serão confiadas tarefas docentes, sem prejuízo do tempo destinado aos seus estudos e trabalhos de pesquisa" (BRASIL, 1965, p. 11).

Foi a partir da Reforma de 1968 que a pós-graduação apresentou uma política nacional conduzida pelas agências de fomento do governo federal (MARTINS, 2009), tornando-se semi autônoma, no entanto estava associada de forma funcional aos departamentos (BALBACHEVSKY, 2009), além de abolir “[...] as cátedras vitalícias, introduziu-se o regime departamental, institucionalizou-se a carreira acadêmica, a legislação pertinente acoplou o ingresso e a progressão docente à titulação acadêmica" (MARTINS, 2009, p. 16).

A partir de 1970 ocorreu o período de mais visibilidade no país, pois o governo iniciou associar o desenvolvimento científico como estratégia de desenvolvimento econômico (BALBACHEVSKY, 2009). Para tanto criou o programa intensivo de pós-graduação a partir do decreto $\mathrm{n}^{\circ}$ 67.348, de 6 de outubro de 1970, a fim de: 
Art.1. [...] incrementar o aperfeiçoamento pós-graduado, mediante cursos e estágios, no País e no Exterior, com vistas ao Desenvolvimento Tecnológico dos setores prioritários, observadas as seguintes principais áreas: I -Tecnologia, sob todos os aspectos; II - Profissões da saúde; III - Administração pública e de empresas; IV - Economia; V - Ciências agrárias. [...] Parágrafo único. O aperfeiçoamento pós-graduado de que trata este artigo será realizado em cursos de Mestrado e Doutorado, credenciados pelo Conselho Federal de Educação (BRASIL, 1970, p. 01).

Em 1977, a partir da resolução CFE/C.E.Su. n n 14/77 também sustentou a implementação dos cursos lato sensu. Esse documento se refere à organização dos cursos de especialização e aperfeiçoamento como instrumento válido para carreira do magistério do Ensino Superior, dentre elas: carga horária e tempo do curso; corpo docente; certificação dentre outros aspectos. Destaque para distribuição dos conteúdos, a qual aponta que menos 4/5 da carga horária mínima deverá contemplar conteúdo específico dos cursos e as demais horas com assuntos complementares e formação didático-pedagógica (BRASIL, 1977). Então surge a fase de normatização, quando acontece a institucionalização desses cursos (MEDEIROS, 2010), passando por três momentos: abalos, ajustes e diretrizes; nova conformação; e novos abalos sustentados pela resolução CFE/C.P. nº 112/83.

Oliveira (1995) aponta que a primeira metade da década de 80 foi marcada por conturbações, problemas econômico-sociais e políticos no país, que interferiram em toda essa estrutura educacional. No entanto a resolução de 83 mostra algumas modificações, dentre elas a formação didático-pedagógica apresenta alterações ao referir-se sobre disponibilizar ao menos 60 horas com conteúdo desse caráter. Além disso, menciona que o restante da carga horária deverá estar sustentado pelo conteúdo específico do curso, incluindo a iniciação à pesquisa (BRASIL, 1983).

A partir das medidas tomadas pelo governo, a pós-graduação no país tornou-se um instrumento fundamental para renovação do Ensino Superior no Brasil (MARTINS, 2009). Em virtude disso, também surgem normas de funcionamento e credenciamento dos cursos de pós-graduação stricto sensu - Resolução no 05 de 1983, permitindo aprofundar pontos norteadores aos cursos, conforme as necessidades surgidas no país, como:

[...] $\S 3^{\circ}$. Os mestrado e doutorado de natureza multidisciplinar ou interdisciplinar, que não correspondam a cursos de graduação, terão denominação específica; [...] $\S 5^{\circ}$. Além do órgão de coordenação central de pós-graduação, as universidades poderão constituir coordenações setoriais, que reúnam cursos afins, visando a estimular a interdisciplinaridade, a unificação pedagógica e administrativa, em articulação com os correspondentes departamentos [...] (BRASIL, 1983, p. 02). 
Por fim, os cursos de pós-graduação lato sensu iniciam uma nova fase, denominada consolidação e tendências, contemplada pelo momento histórico que a consolidou e regulamentou a partir da Resolução CNE/CES nº 01/01 e a atual Resolução CNE/CES no 01/07 (MEDEIROS, 2010). A primeira resolução, de 2001, reorganiza as pós-graduações stricto sensu e lato sensu sustentadas nas modificações sociais, políticas e educacionais do país. Desse modo é possível observar algumas mudanças quanto aos cursos lato sensu: flexibilidade na criação dos cursos e a ocultação da necessidade de conteúdos de cunho didático-pedagógico (FONSECA, 2004). Além disso, esse documento não faz menção sobre a formação docente para o magistério superior nem outro aspecto semelhante, cujo assunto fica restrito à atualização da LDB de 1996 pelo Art. 66, ao abordar que "a preparação para o exercício do magistério superior far-se-á em nível de pós-graduação, prioritariamente em programas de mestrado e doutorado" (BRASIL, 2017, s.p.).

Desde então o Conselho Nacional de Educação "recebeu um pequeno número de Consultas, Propostas de alterações e reanálises dos dispositivos legais" (MEDEIROS, 2010, p. 33), permitindo algumas alterações ou complemento sobre essa resolução de 2001: a) titulação de mestrado profissional - Parecer CNE/CES nº79/2002; b) reconhecimento da pósgraduação lato sensu no exterior - Parecer CNE/CES n²77/2002; c) redução de prazos para pedidos de reconhecimento de novos cursos, criados por IES com competência para tal Resolução CNE/CES no 24/2002; d) vincular a oferta de especialização às instituições devidamente credenciadas e que possuem cursos de graduação na área; melhorar as descrições sobre os aspectos inerentes ao quadro docente; distinção de curso de especialização e aperfeiçoamento - Parecer CNE/CES 263/06 (MEDEIROS, 2010); e) esgotamento de acolhimento do pedido de reconhecimento pelas universidades, cabe recurso à Câmara de Educação Superior do Conselho Nacional de Educação - Resolução nº 06/09 (BRASIL, 2009).

Por fim, a Resolução nº 01/01, revogada pela Resolução nº1/07, faz menção especificamente aos cursos de pós-graduação lato sensu em nível de especialização. A última resolução também não faz referência às obrigatoriedades dos conteúdos didáticopedagógicos, bem como ao foco para formação de magistério de Ensino Superior. No Parecer 187/2002 homologado, entretanto, justifica-se a ausência de aspectos inerentes à formação docente para o Ensino Superior, já percebido, inicialmente, na Resolução 01/01: 
atual legislação deixa sem suporte legal a validação do título de especialista na qualificação de docentes para o magistério superior (BRASIL, 2002, p. 01).

Conforme tal justificativa, o presente estudo viu-se na necessidade de identificar o cenário dos cursos de pós-graduação lato sensu, que visam à formação da docência no Ensino Superior, devidamente credenciados no MEC. Assim, utilizou-se como base de coleta de informações E-MEC: busca por - curso de especialização; curso: docência no ensino superior e didática e metodologia do ensino superior. Também se utilizaram como critério as modalidades dos cursos a distância e presencial, bem como em situação ativa (Tabela 1). Importante salientar que esses dados foram coletados em junho de 2017.

Percebemos que a predominância dos cursos consistiu na modalidade presencial ( $n=189)$ em comparação com a distância (n=28). Também pudemos identificar quais cursos estão centralizados na área da Educação, entretanto percebemos outras áreas nas duas modalidades como: humanidades e artes; saúde e bem-estar social; ciências sociais, negócios e direito; ciências, matemática e computação; e agricultura e veterinária.

Tabela 1 - Retrato dos cursos de pós-graduação lato sensu de Didática e Metodologia do Ensino Superior e

\begin{tabular}{|c|c|c|c|}
\hline Cursos & Modalidades & Área(s) & $\mathbf{N}^{\mathbf{0}}$ \\
\hline \multirow{8}{*}{$\begin{array}{l}\text { Didática e Metodologia do } \\
\text { Ensino Superior }\end{array}$} & \multirow{6}{*}{ Presencial } & - Educação & 63 \\
\hline & & - Humanidades e artes & 02 \\
\hline & & - Saúde e bem-estar social & 03 \\
\hline & & - Ciências sociais, negócios e direito & 01 \\
\hline & & - Ciências, matemática e computação & 01 \\
\hline & & Total & 70 \\
\hline & \multirow{2}{*}{ A Distância } & - Educação & 05 \\
\hline & & Total & 05 \\
\hline \multirow{10}{*}{ Docência no Ensino Superior } & \multirow{6}{*}{ Presencial } & - Educação & 113 \\
\hline & & - Ciências sociais, negócios e direito & 03 \\
\hline & & - Humanidades e artes & 01 \\
\hline & & - Agricultura e veterinária & 01 \\
\hline & & - Saúde e bem-estar social & 01 \\
\hline & & Total & 119 \\
\hline & \multirow{4}{*}{ A Distância } & - Educação & 21 \\
\hline & & - Ciências sociais, negócios e direito & 01 \\
\hline & & - Humanidades e artes & 01 \\
\hline & & Total & 23 \\
\hline
\end{tabular}

Fonte: Elaborada pela pesquisadora (2017)

Além dos dados apresentados na Tabela 1, também foram observadas distintas denominações, no entanto predominaram as nomenclaturas de busca - Didática e Metodologia do Ensino Superior e Docência no Ensino Superior. Observamos, todavia, que a maioria, em seu título, contemplava a atuação docente no Ensino Superior de forma geral. 
Apareceram algumas especificidades que contemplam a necessidade acadêmica, permitindo a qualificação em libras, informática, docência na área da saúde, gestão, ensino a distância, arte contemporânea, novas tecnologias e psicomotricidade. No Quadro 1 estão dispostas todas as denominações encontradas conforme a busca de informações.

\begin{tabular}{|c|c|c|}
\hline Cursos & Modalidades & Denominacões \\
\hline \multirow{6}{*}{$\begin{array}{l}\text { Didática e Metodologia do } \\
\text { Ensino Superior }\end{array}$} & \multirow{5}{*}{ Presencial } & $\begin{array}{l}\text { Metodologia do Ensino Superior e novas } \\
\text { tecnologias; }\end{array}$ \\
\hline & & $\begin{array}{c}\text { Metodologia do Ensino Superior, médio e } \\
\text { técnico }\end{array}$ \\
\hline & & Metodologia do Ensino Superior XXI \\
\hline & & Metodologia do Ensino Superior \\
\hline & & $\begin{array}{c}\text { Metodologia do Ensino Superior e da } \\
\text { Educação Básica }\end{array}$ \\
\hline & A Distância & Metodologia do Ensino Superior \\
\hline \multirow{10}{*}{$\begin{array}{l}\text { Docência no Ensino } \\
\text { Superior }\end{array}$} & \multirow{9}{*}{ Presencial } & $\begin{array}{l}\text { Arte contemporânea e docência no Ensino } \\
\text { Superior }\end{array}$ \\
\hline & & $\begin{array}{c}\text { Docência no ensino superior: novas } \\
\text { tecnologias }\end{array}$ \\
\hline & & $\begin{array}{c}\text { Docência no Ensino Superior para educação } \\
\text { presencial e EAD }\end{array}$ \\
\hline & & $\begin{array}{c}\text { Gestão Acadêmica, Gestão Educacional } \\
\text { Gestão Escolar e Docência no Ensino } \\
\text { Superior }\end{array}$ \\
\hline & & $\begin{array}{c}\text { Docência no Ensino Superior para } \\
\text { profissionais da saúde }\end{array}$ \\
\hline & & $\begin{array}{c}\text { Informática na educação e docência no } \\
\text { Ensino Superior }\end{array}$ \\
\hline & & $\begin{array}{c}\text { Libras para docência no Ensino Superior e } \\
\text { Básico para intérprete }\end{array}$ \\
\hline & & Docência no Ensino Superior e andragogia \\
\hline & & $\begin{array}{c}\text { Psicomotricidade e Docência no Ensino } \\
\text { Superior }\end{array}$ \\
\hline & A Distância & Gestão e Docência no Ensino Superior \\
\hline
\end{tabular}

Fonte: Elaborado pela pesquisadora (2017)

A carga horária (C.H.) e as vagas disponíveis nos cursos (Tabela 2) também foram analisadas, identificando-se que as médias da C.H. dos cursos presencial e a distância obtiveram uma variação entre 399,77 e 425 . A diferença de C.H. entre essas modalidades foi de aproximadamente 11 horas. Quanto à C.H, mínima, foram iguais em todos os cursos e modalidades, os quais estão devidamente enquadrados na Resolução 01/07, que estipula a C.H. mínima de 360 horas (BRASIL, 2007). Quanto à C.H. máxima, os cursos a distância 
apresentaram quantidade menor que os cursos presenciais, cuja C.H. é dobrada, exigida pela legislação vigente.

As vagas apresentaram uma média de 75 vagas por cursos, mínima de 10 e máxima de 5050. O sistema utilizado como fonte de dados, entretanto, apresenta a instituição, denominação do curso, os estados em que são ministrados e o número de vagas totais, não discriminando a quantidade por local. Alguns cursos são oferecidos em mais de um estado, assim somam-se todas as vagas, independe da localidade, o que justifica a diferença entre o mínimo e o máximo de vagas oferecidas.

Tabela 2 - Dados sobre a carga horária e as vagas ofertadas nos cursos de pós-graduação lato sensu de Didática e Metodologia do Ensino Superior e Docência no Ensino Superior

\begin{tabular}{c|c|c|c|c|c|c|c|c}
\hline \multirow{2}{*}{ Cursos } & \multicolumn{2}{c|}{$\begin{array}{c}\text { Didática e } \\
\text { Metodologia do } \\
\text { Ensino Superior }\end{array}$} & \multicolumn{2}{c|}{$\begin{array}{c}\text { Didática e } \\
\text { Metodologia do } \\
\text { Ensino Superior }\end{array}$} & $\begin{array}{c}\text { Docência no } \\
\text { Ensino Superior }\end{array}$ & \multicolumn{2}{c}{$\begin{array}{c}\text { Docência no } \\
\text { Ensino Superior }\end{array}$} \\
\cline { 2 - 9 } Variáveis & Presencial & \multicolumn{2}{|c|}{ A Distância } & \multicolumn{2}{c|}{ Presencial } & \multicolumn{2}{|c}{ A Distância } \\
\cline { 2 - 9 } & C.H. & Vagas & C.H. & Vagas & C.H. & Vagas & C.H. & Vagas \\
\hline Média & 399,7 & 75,33 & 388 & 87 & 413,72 & 168,23 & 425 & 376,52 \\
\hline Mínima & 360 & 10 & 360 & 35 & 360 & 20 & 360 & 50 \\
\hline Máxima & 780 & 300 & 410 & 200 & 720 & 5050 & 635 & 2000 \\
\hline
\end{tabular}

Fonte: Elaborada pela pesquisadora (2017)

C.H. - Carga Horária

Em virtude disso, vimos a necessidade de apresentar a distribuição dos cursos conforme as regiões do país, considerando que há cursos oferecidos em mais de um estado. Assim identificamos que, nos cursos presenciais de Didática e Metodologia do Ensino Superior, as instituições ofertam o mesmo curso em 10, 5, 3 e 2 estados distintos. Nos cursos presenciais sobre Docência no Ensino Superior, verificamos instituições com disponibilidade para a mesma especialização em $20,16,14,8,7,6,5,3$ e 2 estados.

Mostra a Tabela 3 que a oferta de cursos lato sensu com a preocupação em docência no Ensino Superior, está mais centrada nas respectivas regiões: sudeste, nordeste e norte. Destacamos ainda a maior evidência na oferta dos cursos presenciais em todas as regiões do país. Sabemos que na região sudeste se encontra o centro dos cursos de pós-graduação, lato sensu e stricto sensu, principalmente no estado de São Paulo, onde predomina a potência de fomento e a qualidade de formação profissional. Os estados de Rondônia, Bahia, Goiás, Mato Grosso, Paraná e o Distrito Federal, todavia, vêm disponibilizando mais cursos nessa área de formação que os demais estados brasileiros. 
Tabela 3 - Distribuições de oferta dos cursos de pós-graduação lato sensu de Didática e Metodologia do Ensino Superior e Docência no Ensino Superior conforme as regiões do Brasil

\begin{tabular}{c|c|c|c|c|c}
\hline Cursos & $\begin{array}{c}\text { Didática e } \\
\text { Metodologia } \\
\text { do Ensino } \\
\text { Superior }\end{array}$ & $\begin{array}{c}\text { Didática e } \\
\text { Metodologia } \\
\text { do Ensino } \\
\text { Superior }\end{array}$ & $\begin{array}{c}\text { Docência no } \\
\text { Ensino } \\
\text { Superior }\end{array}$ & $\begin{array}{c}\text { Docência no } \\
\text { Ensino } \\
\text { Superior }\end{array}$ & \multirow{2}{*}{ Total } \\
\cline { 2 - 5 } & Presencial & A Distância & Presencial & A Distância & \\
\hline Norte & 21 & 1 & 35 & 1 & 58 \\
\hline Nordeste & 32 & 0 & 34 & 2 & 68 \\
\hline Centro-oeste & 9 & 1 & 33 & 1 & 44 \\
\hline Sudeste & 9 & 3 & 67 & 10 & 89 \\
\hline Sul & 10 & 0 & 27 & 9 & 46 \\
\hline
\end{tabular}

Fonte: Elaborada pela pesquisadora (2017)

Por fim, atualmente, são ofertados em todo país 314 cursos, considerando que instituições privadas vêm investindo em distintos estados no mesmo curso, a fim de oportunizar qualificação docente no Ensino Superior à população brasileira. Em contrapartida, percebemos a insatisfação quanto às políticas de criação e à fiscalização dos cursos de pós-graduação lato sensu nas últimas três décadas, pois autores como Oliveira (1995), Fonseca (2004) e Medeiros (2010) relatam em suas obras o desgosto quanto a esses aspectos, ao entenderem que prejudicam a qualidade da formação. No que tange à investigação acerca dos cursos sobre formação de professores para o Ensino Superior, não foi possível identificar a qualidade dos cursos, mas ficou visível que há preocupação com a docência para o magistério superior.

Enquanto o desenvolvimento dos cursos de pós-graduação stricto sensu vão se ajustando, tomando consistência em suas propostas, podemos perceber seu crescimento, pois, em 1965, havia 27 mestrados e 11 doutorados, já em 1975 alcançou o número de 429 mestrados e 149 doutorados (AZEVEDO; OLIVEIRA; CATANI, 2016). Ao lançarmos um olhar panorâmico, a partir de 1970 até o início da década de 90, identificamos 1.500 cursos em todas as áreas (VELLOSO, 2004). Não obstante, a Lei 9394/96 também contribuiu para mais assentamento dos cursos, bem como a Resolução CNE/CES nº 1/2001 que estabelece normas para o funcionamento de cursos de pós-graduação fundados nos demais pareceres e resoluções existentes, destacando o reconhecimento dos cursos no exterior e cursos a distância (BRASIL, 2001a).

A Geocapes (2016) permite a identificação dos dados quantitativos sobre a pósgraduação no Brasil de 1998 até 2014. Primeiramente, organizamos a quantidade dos cursos, conforme a distribuição dos programas por grau, do ano de 1998, 2002, 2006, 2010 e 2014 (Gráfico 1), ou seja, utilizamos o intervalo de quatro em quatro anos. Dessa forma, 
verificamos que houve um desenvolvimento gradativo e crescente dos programas, independente do grau, predominando programas que contemplam o mestrado/doutorado $(\mathrm{n}=1.957)$. No último levantamento, em 2017, permanece a realidade crescente retratada em todos os cursos no período analisado no Gráfico 1, tal aumento foi de: 181 cursos de mestrado/doutorado (MD); 160 de mestrado acadêmico (M); 198 de mestrado profissional (MF); e 22 de doutorado (D) (GEOCAPES, 2018).

A incidência de programas de mestrado acadêmico ainda é praticamente o dobro da oferta de mestrado profissional, no entanto vem ganhando espaço no contexto formativo, considerando que o aumento ocorrido entre 2014 e 2017 foi maior no MF. Esse crescimento dos programas e cursos de pós-graduação, bem como do aumento da produção científica, está aliado às ações desenvolvidas pelas Agências de Fomento como Coordenação de Aperfeiçoamento de Pessoal de Nível Superior - CAPES, Conselho Nacional de Desenvolvimento Científico e Tecnológico - CNPq, Financiadora de Estudos e Projetos (FINEP) e as Fundações Estaduais de Apoio à Pesquisa (FAPs) (DANTAS, 2004; AZEVEDO; OLIVEIRA; CATANI, 2016).

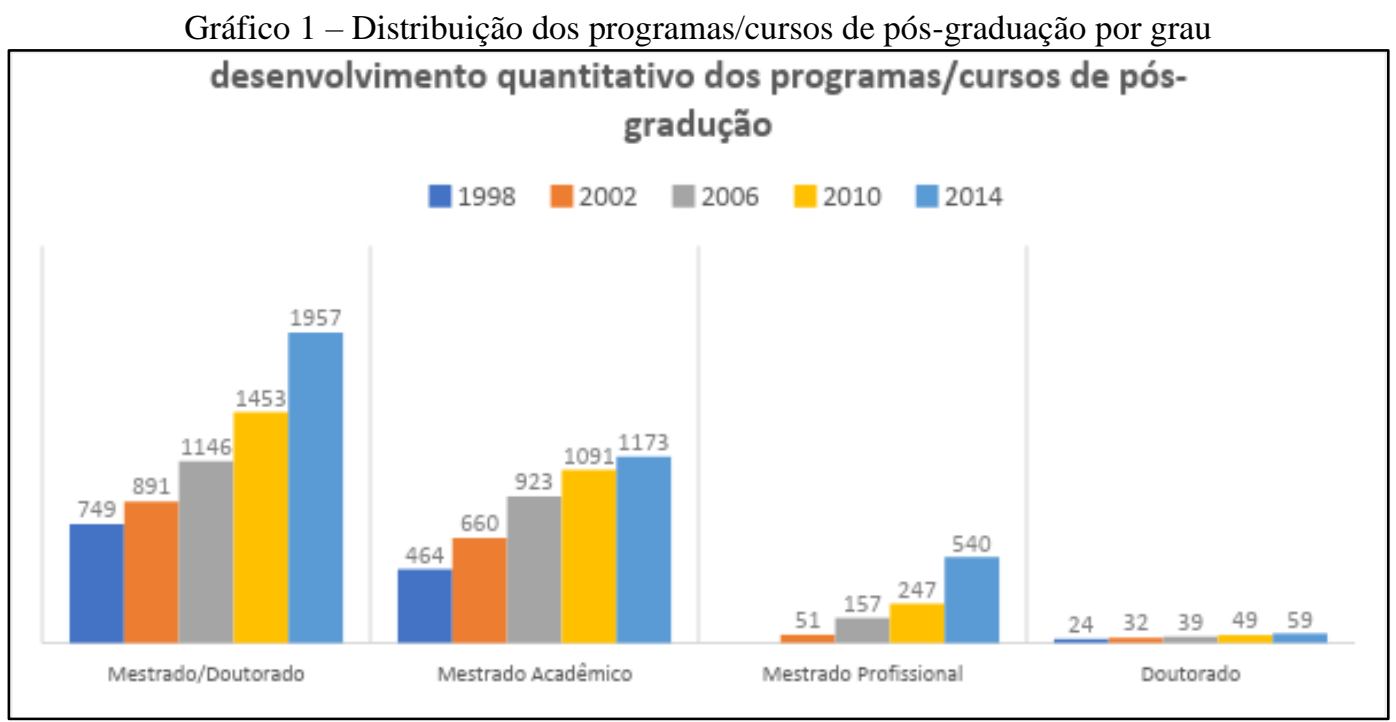

Fonte: Adaptado do Geocapes (2016)

Realizamos a mesma análise dos programas a partir do status jurídico (Gráfico 2), isto é, separamos os programas conforme a oferta em instituição privada, municipal, estadual e federal. Assim, percebemos a predominância nas instituições federais, em todos os anos, seguindo para as estaduais, ou seja, no ano de 2014, aproximadamente $81,86 \%(n=3.051)$ dos programas de pós-graduação no país eram gratuitos (IES federais, estaduais e municipais), assim como a mesma proporção no ano de 2017 ( $n=3.454 ; 80,40 \%)$. 
As instituições públicas (federais e estaduais) que oferecem curso de pós-graduação são consideradas maiores fontes de conhecimento no Brasil, bem como apresentam excelência nessa formação (AZEVEDO; OLIVEIRA; CATANI, 2016). As instituições municipais, no entanto, não se enquadram ainda nessa realidade de grande oferta, pois há poucos programas e cursos de mestrado e doutorado nessas IES.

Ao comparar os períodos 1998 a 2014, conforme o gráfico 2, e os últimos dados fornecidos pela Geocapes (2018) sobre o ano de 2017, identificamos que, entre 2010-2014, houve o maior índice de surgimento de programas de pós-graduação ocorridas em IES federais $(n=556)$, estaduais $(n=184)$ e municipais $(n=6)$. Na IES privada o ápice ocorreu no período 2002-2006 com o surgimento de 177 programas. Entre 2014-2017 ocorreu aumento no número de programas, na seguinte progressão: IES federais $(n=344)$, privada $(n=116)$, estadual $(n=106)$ e municipal $(n=3)$.

Gráfico 2 - Distribuição dos programas de pós-graduação por status jurídico

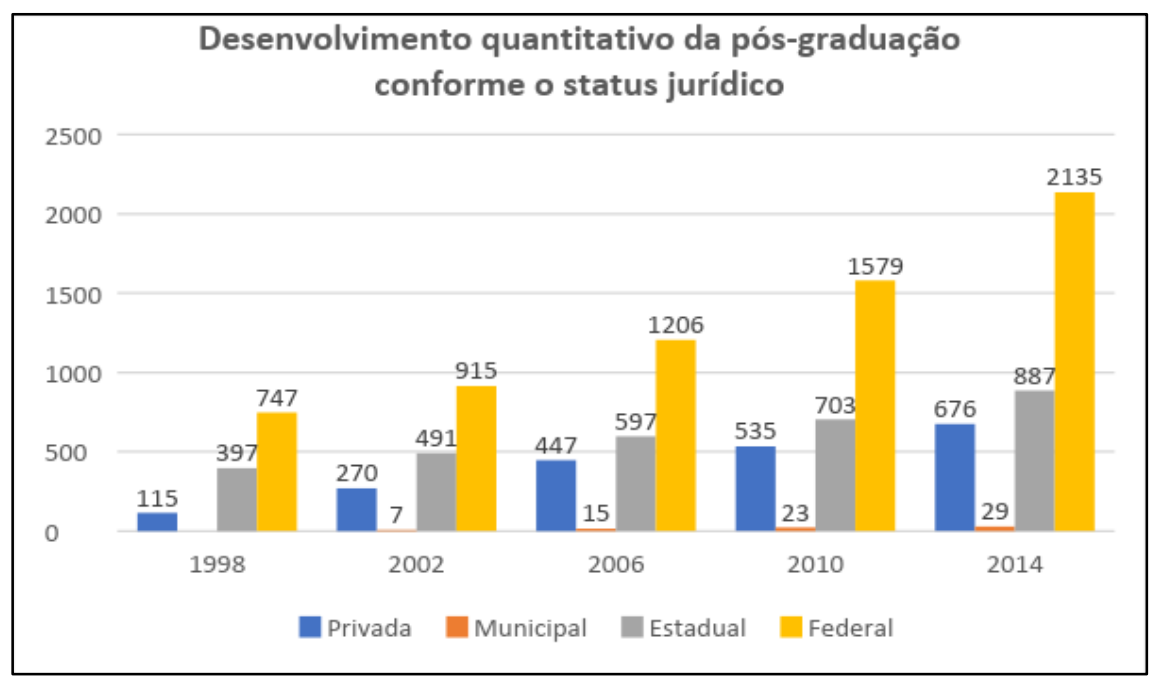

Fonte: Adaptado da Geocapes (2016)

Também analisamos a distribuição dos programas de pós-graduação conforme cada região do país, percebemos, em todos os anos, que a região sudeste (Gráfico 3) apresentou a maior quantidade, seguida da região sul. E todas as regiões aumentaram a distribuição, de acordo com o período anterior analisado, até mesmo no último ano de 2017 , conforme a Geocapes (2018). Apenas dessa realidade de predominância das regiões sudeste e sul, verificamos que, nos períodos 2002-2006, 2006-2010 e 2014-2017, surgiram mais programas a região nordeste (respectivamente $-\mathrm{n}=135 ; \mathrm{n}=149 ; \mathrm{n}=180)$ que na região sul do país $(\mathrm{n}=123$; $\mathrm{n}=135 ; \mathrm{n}=140$ ). 
Gráfico 3 - Distribuição dos programas/cursos de pós-graduação por regiões do Brasil

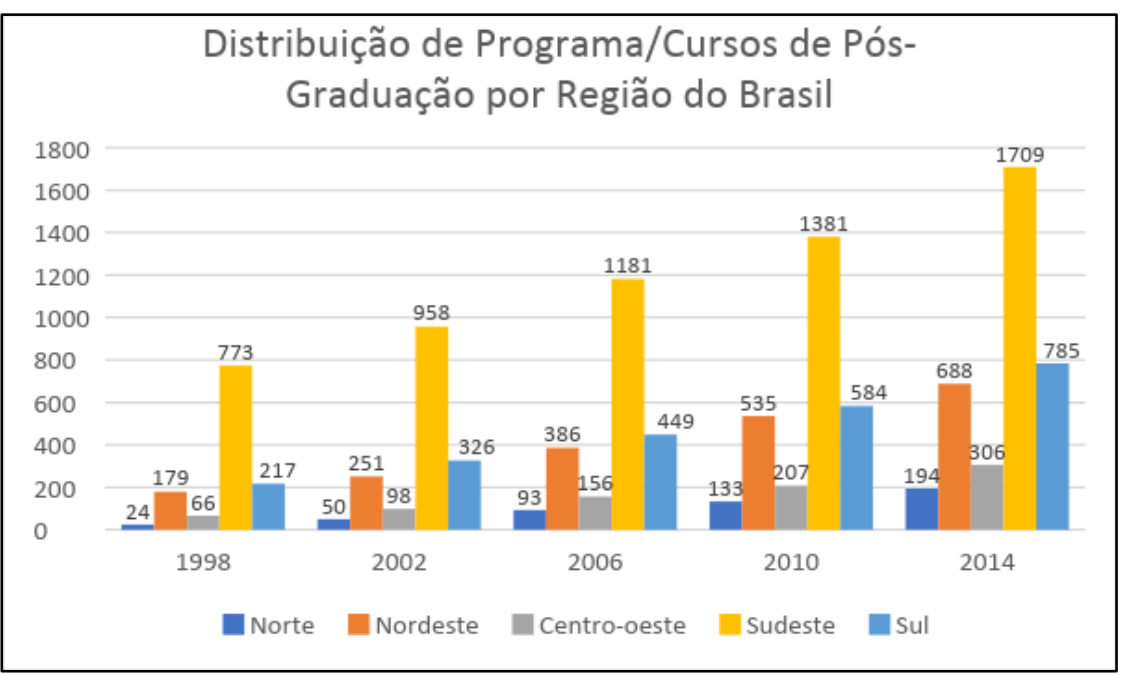

Fonte: Adaptado do Geocapes (2016)

Quanto ao Plano Nacional de Pós-Graduação - PNPG de 2011-2020 (BRASIL, 2010), no entanto, é possível identificarmos a existência de desigualdade entre as regiões brasileiras, mas visam combater essa assimetria nas grandes regiões, bem como nas mesorregiões. O estudo de Balbachevsky (2009) permitiu verificar essa desigualdade regional de outra forma, pois analisou a relação entre o total do número dos pós-graduandos matriculados e dez mil habitantes de cada região (Figura 1). Essa proporção permite identificar o acesso à pós-graduação e, mais uma vez, mostrou a discrepância conforme as populações nas regiões do país. A autora ainda aponta que, devido a essa diferenciação, há uma situação de apadrinhamento nas regiões norte e nordeste, a partir de uma organização financeira específica para essas regiões, devido à restrição ao acesso. Em contrapartida, a exigência nos programas é menor, tal situação busca favorecer os pesquisadores da região e não buscar uma qualidade nos programas e cursos para instigar a procura de outros profissionais, a fim de estudarem na região (BALBACHEVSKY, 2009).

A partir da avaliação da CAPES nos programas e cursos de pós-graduação, é possível identificar aqueles que apresentam melhores recursos, proporcionando qualidade na formação e desenvolvimento da pesquisa científica no país. Em virtude disso, a Capes e demais agências de fomento investem nesses programas e cursos, os quais se tornam atrativos aos profissionais que buscam essa formação, bem como aos pesquisadores doutores que almejam uma carreira acadêmica promissora. Não obstante, a maioria desses programas são os responsáveis pela formação de doutores do país, concentrados nos nichos específicos de investimento e regiões do Brasil, basicamente sudeste e sul (BALBACHEVSKY, 2009). 
Figura 1 - Total de matrículas na pós-graduação por região e proporção de matrículas por dez mil habitantes, Brasil, 2000

\begin{tabular}{|l|c|c|c|c|}
\hline & \multicolumn{2}{|c|}{ Matriculas por nivel do programa (\%) } & Total (\%) & $\begin{array}{c}\text { Total de matrículas } \\
\text { por dez mil } \\
\text { habitantes }\end{array}$ \\
\hline Centro-Oeste & Mestrado & Doutorado & & 2,7 \\
Nordeste & 4,3 & 2,2 & 3,8 & 0,2 \\
Norte & 10,8 & 4,8 & 9,2 & 0,7 \\
Sudeste & 1,3 & 0,6 & 1,1 & 8,5 \\
Sul & 65,2 & 80,5 & 75,1 & 5,6 \\
Total & 18,4 & 11,9 & 17,1 & Brasil: 4,8 \\
\hline
\end{tabular}

Fonte: Balbachevsky (2009, p. 285)

Além dos dados estatísticos sobre os programas desde 1998 a 2017 dispostos na Geocapes $(2016$; 2018), a Plataforma Sucupira (2018a) disponibiliza também uma tabela com os dados registrados com o número existente de programas e cursos de pós-graduação (Tabela 4). Percebemos que os últimos dados da Geocapes (2018) são distintos da Plataforma Sucupira, dessa forma consideramos que a plataforma realizou a computação dos dados de 2018, haja vista que à Geocapes corresponde apenas o ano de 2017.

O objetivo do PNPG (BRASIL, 2010) para 2011 a 2020 está se concretizando aos poucos, pois há expansão dos programas e cursos nas demais regiões - centro-oeste, nordeste e norte. Esse crescimento, todavia, está acontecendo de forma semelhante em todas as regiões, identificado pela Geocapes (2018) nos anos de 2014 a 2017 e pela Plataforma Sucupira (2018a) no ano de 2018.

Tabela 4 - Programas de pós-graduação e Cursos de pós-graduação no Brasil registrados em 2018

\begin{tabular}{|c|c|c|c|c|c|c|c|c|c|c|c|c|}
\hline \multirow{2}{*}{$\begin{array}{l}\text { Cursos e } \\
\text { Programas } \\
\text { Região }\end{array}$} & \multicolumn{7}{|c|}{ Total de Programas de pós-graduação } & \multicolumn{5}{|c|}{ Totais de Cursos de pós-graduação } \\
\hline & $\mathrm{T}$ & $\mathrm{ME}$ & DO & MP & $\mathrm{DP}$ & $\begin{array}{l}\mathrm{ME} / \\
\mathrm{DO}\end{array}$ & $\begin{array}{c}\mathrm{MP} \\
/ \mathrm{M} \\
\mathrm{D}\end{array}$ & $\mathrm{T}$ & ME & DO & MP & DP \\
\hline $\begin{array}{c}\text { CENTRO- } \\
\text { OESTE }\end{array}$ & 374 & 139 & 11 & 58 & 0 & 166 & 0 & 540 & 305 & 177 & 58 & 0 \\
\hline NORDESTE & 929 & 384 & 20 & 159 & 1 & 365 & 0 & 1.294 & 749 & 385 & 160 & 2 \\
\hline NORTE & 261 & 122 & 3 & 51 & 0 & 85 & 0 & 351 & 207 & 89 & 55 & 3 \\
\hline SUDESTE & 1.975 & 398 & 41 & 382 & 1 & 1.153 & 0 & 3.133 & 1.551 & 1.194 & 388 & 7 \\
\hline SUL & 973 & 298 & 13 & 161 & 0 & 501 & 0 & 1.478 & 799 & 514 & 165 & 7 \\
\hline Totais & 4.512 & 1.341 & 88 & 811 & 2 & 2.270 & 0 & 6.812 & 3.611 & 2.359 & 826 & 16 \\
\hline
\end{tabular}

Fonte: Plataforma Sucupira (2018a)

ME - Mestrado acadêmico

DO - Doutorado acadêmico

ME/DO - Mestrado e Doutorado acadêmico

MP - Mestrado Profissional

DP - Doutorado Profissional

MP/DP - Mestrado e Doutorado Profissional

T - Total 
O Fórum Nacional de Educação aponta os indicadores e desafios para a Educação brasileira, pormenorizando a pós-graduação e respectivo desenvolvimento no país. Assim aponta que seu crescimento está associado: a) à Educação Básica, quanto à ampliação dos anos de estudo, ao aumento das taxas de aproveitamento e sua conclusão; b) Expansão da Educação Superior; c) às políticas de acesso e permanência, bem como às políticas relacionadas à formação inicial e continuada de professores, tanto para os que atuam na Educação Básica quanto na Educação Superior; d) as políticas e ações, específicas para expansão de programas de pós-graduação, cursos e matrículas e formação de pesquisadores em todas as regiões do país (FERNANDES, 2013).

O PNPG revela, entretanto, a preocupação com a Educação Básica, causada pela excessiva evasão escolar ao longo da trajetória educacional e devido à insatisfação dos resultados apresentados pela Educação Básica na formação. Isso leva a compreender que a ampliação do número de estudantes, no mestrado e doutorado, só se fará com a melhora do sistema educativo como um todo, sobretudo Educação Básica. Caso contrário, resultará na falta de estudantes capacitados e com disponibilidade para se inserirem em programas e cursos stricto sensu (BRASIL, 2010).

Diante disso, vimos a necessidade de analisar a distribuição dos discentes matriculados e titulados pelos programas de pós-graduação de 1998 a 2014 (Gráfico 4). Ao longo do tempo, o número de matriculados aumentou, resultante da criação de novos programas, no entanto a obtenção do título alcançou menos de $50 \%$ dos discentes matriculados no mestrado acadêmico, doutorado e mestrado profissional. Tal resultado pode ser reflexo dessa preocupação apontada pelo PNPG (BRASIL, 2010) sobre a falta de capacidade e disponibilidade para cursar a pós-graduação.

Entre os cursos de pós-graduação stricto sensu, o mestrado acadêmico predominou no número de matriculados e titulados entre 1998 a 2014, em detrimento do doutorado e mestrado profissional. Haja vista que no ano de 2017 foram matriculados 278.792 no mestrado $(n=129.220)$, doutorado $(n=112.004)$ e mestrado profissional $(n=37.568)$, superando os demais anos (GEOCAPES, 2018).

Ao analisarmos os titulados, existe uma proporção menor que $50 \%$ daqueles que se matriculam finalizando o curso de pós-graduação, embora esses dados sejam gerais, podemos exemplificar: o doutorado leva aproximadamente quadro anos para sua conclusão, se em 2010 matricularam-se 64.588, enquanto em 2014 tornaram-se doutores 17.048, isso equivale a 26,39\% dos pós-graduandos ingressantes. No ano de 2014 ingressaram 115.552 mestrandos, mas no ano de 2016 finalizaram 49.002, em 2017 foram 50.306 (GEOCAPES, 
2018). Ao utilizar o tempo aproximado de finalização de dois a três anos do curso, percebemos que houve, respectivamente, $42,40 \%$ e $43,53 \%$ de concluintes.

Gráfico 4 - Distribuição dos discentes dos programas de pós-graduação

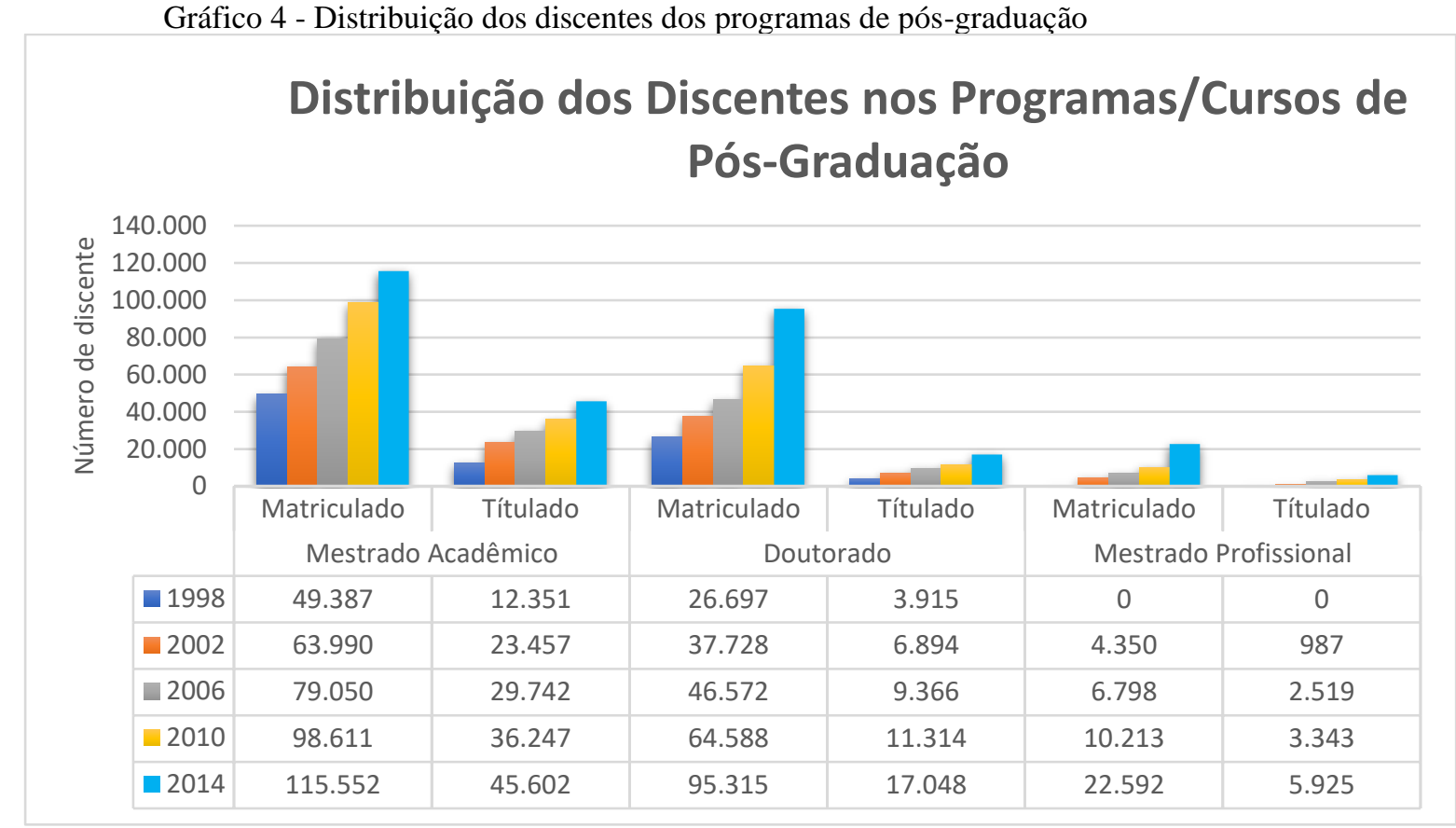

Fonte: Adaptado do Geocapes (2016)

A maior parte desses titulados tornam-se professores do Ensino Superior, pois constatamos que a preparação para o magistério superior acontecerá, prioritariamente, nos programas e cursos de mestrado e doutorado. Logo, na atual conjuntura do país e respectiva legislação vigente, é de responsabilidade dos programas de pós-graduação stricto sensu dispor de ferramentas e fundamentos adequados para a formação de professores para atuarem no Ensino Superior. No entanto o PNPG avaliza que a pesquisa é o núcleo da pós-graduação stricto sensu (BRASIL, 2010).

Em virtude disso, vimos a necessidade de discutir especificamente a formação docente dos programas de pós-graduação, pois foi possível identificar o contexto histórico da pós-graduação e o cenário atual, conforme os resultados apresentados pela Geocapes (2016; 2018), bem como a legislação vigente, cujos pontos norteadores da pós-graduação são a pesquisa científica e a produção do conhecimento, que, no Brasil, estão centrados nas universidades e institutos específicos. Tais fatos induzem mestres e doutores a se inserirem nas IES, em busca da pesquisa, realidade que nem sempre é possível da forma almejada. Sabemos que, ao finalizar a pós-graduação, a inserção numa universidade, que visa à pesquisa, ao ensino e à extensão são para poucos, o que os levam à inserção em centrosuniversitários, faculdades, institutos e escolas superiores. O perfil do trabalho nessas demais 
instituições não visa prioritariamente à pesquisa, muitas vezes, encontra-se ausente em determinadas realidades. As universidades privadas, entretanto, precisam da realização da pesquisa, mas os custos financeiros são reduzidos, assim os docentes realizam estudos de pequeno porte, a partir dos projetos institucionais, ou ainda, associando-a aos Trabalhos de Conclusão de Curso - TCC de seus orientandos.

Em contrapartida, conforme Morosini (2001), nas universidades, principalmente as públicas, a pesquisa e a extensão predominam em relação ao ensino. Tal realidade se sustenta a partir do art. 57 da LDB, ao abordar que os professores das IES públicas devem, obrigatoriamente, cumprir, no mínimo, oito horas semanais de aula (BRASIL, 2017). Assim o professor assume apenas carga horária necessária junto ao ensino, deixando o restante de suas horas para demais funções: pesquisa, extensão e demandas administrativas.

Concordamos que a docência é obrigação de todos os professores do Ensino Superior, mas os contratados pelas IES privadas não esperam outra função, como de pesquisa, extensão ou gestão. Ao contrário dos professores de IES pública, principalmente nas universidades, antes mesmo do ingresso, identificam-se com outras demandas depois o ensino. Tal realidade retrata a ausência de prioridade no ensino por essa classe de professores, favorecendo outras funções com melhor prestígio ou menos desgaste (ALMEIDA, 2012).

Para tanto, a docência do Ensino Superior tem um papel importante na sociedade, cuja responsabilidade é a formação de profissionais que serão inseridos nos distintos campos de atuação. Assim, sua função vai além do ensino dos conhecimentos técnico-científicos especializados, necessita também de conhecimento que engloba a dimensão ética e a responsabilidade social. A formação deve ultrapassar as barreiras do conhecimento específico, pois os profissionais devem ser competentes e sintonizados com as demandas do mundo atual, provido de senso de justiça social e cidadania democrática (ALMEIDA; PIMENTA, 2011).

Na perspectiva de Aquino e Puentes (2011), o docente atuante na Educação Superior pode apresentar seu perfil à luz de duas vertentes: a) formação especializada na ciência, conduzida pela formação de especialização, mestrado, doutorado e pós-doutorado; formação como pesquisador, produtor, divulgador de novos conhecimentos e tecnologias, que leva à atualização sistemática, cultura geral, idiomas, filosofia etc. b) formação pedagógica gozando do conhecimento didático, do contexto universitário, políticas educacionais, modelos pedagógicos com que se trabalha, visão interdisciplinar e transdisciplinar, atitude compreensiva, postura autocrítica e reflexiva sobre a prática. O professor do Ensino Superior, entretanto, precisa reunir essas duas vertentes abordadas por Aquino e Puentes (2011), dessa 
forma é possível identificar na literatura autores que discutem sobre as necessidades da pósgraduação para formação do professor do Ensino Superior para além dos aspectos técnicocientíficos.

Assim, foram separadas algumas perspectivas de autores em períodos diferentes sobre essa questão. Na concepção de Pachane (2006), Almeida (2012) e Masetto (2015a), a pósgraduação stricto sensu vem se preocupando preferencialmente com a pesquisa, produção do conhecimento e construções de projetos individuais, ofuscando as atividades pedagógicas que contribuem também para formação do docente universitário.

Os cursos de pós-graduação, responsáveis pela formação dos professores universitários, têm, por sua vez, priorizado a condução de pesquisas e a elaboração de projetos individuais (dissertações ou teses), pouco ou nada oferecendo aos pósgraduandos em termos de preparação específica para a docência. Dessa forma, terminam, mesmo que não intencionalmente, por reproduzir uma situação em que atividades de ensino e pesquisa são realizadas de modo dissociado, ou mesmo equivocado, e por perpetuar a noção de que para ser professor basta conhecer a fundo determinado conteúdo e, no caso específico do ensino superior, ser um bom pesquisador (PACHANE, 2006, p. 98).

Além disso:

Os processos de "preparação do docente" para o ensino superior, segundo o estabelecido na LDB no 9.394/1996 são desenvolvidos nos cursos de pósgraduação stricto sensu, nos quais sabemos, os objetivos centrais são a pesquisa e a produção do conhecimento. Os aspectos relativos à preparação pedagógica para o ensino raramente são partes desses cursos [...] (ALMEIDA, 2012, p. 63).

Quanto aos cursos:

[...] a formação do pesquisador é muito bem trabalhada, o que é necessário, inclusive, para formação do docente. Mas a pesquisa volta-se, como é de esperar, para o aprofundamento de conteúdos e descobertas de aspectos inéditos de determinada área de conhecimento ou de tecnologias novas. O mestre ou o doutor sai da pós-graduação com mais domínio em um aspecto do conhecimento com habilidade de pesquisar [...] em geral, os cursos de pós-graduação não são suficientes aos mestrandos e doutorandos para lhes oferecer uma formação pedagógica que lhes confira competências para docência universitária (MASETTO, 2015a, p. 200).

Em contrapartida os autores Pereira e Medeiros (2011) e Therrien, Dias e Leitinho (2016) consideram que o professor universitário necessita de conhecimento específico, relacionado à sua área de atuação. Entretanto também precisamos dos conhecimentos didático-pedagógicos, os quais contribuem para a qualidade do ensino.

[...] é preciso também um maior empenho dos programas de pós-graduação stricto sensu no sentido da formação para a docência no nível superior, visto que, grande parte dos mestres e doutores formados nesses programas, se dedica às atividades 
de docência universitária [...]. O professor universitário é um educador e sua atuação profissional compreende muitas dimensões e componentes. A preparação para esta atuação requer uma especificidade pedagógica além do conhecimento técnico-científico de áreas diversas do conhecimento e está na metodologia ou didática do ensino superior a possibilidade de realizar com qualidade tal preparação (PEREIRA; MENDEIROS, 2011, p. 178-179).

A docência universitária também requer formação profissional específica para seu exercício, a fim de ultrapassar os limites entre a formação/profissionalização e o pragmatismo impostos pelo desconhecimento, por parte dos professores e das instituições de educação superior (IES), da necessária formação pedagógica, pela falta de política pública para formação docente nesse nível e pela falta de uma política institucional consistente e permanente em cada IES [...] (THERRIEN; DIAS; LEITINHO, 2016, p. 22).

É possível compreendermos, a partir dessas citações, que a formação para a docência pela pós-graduação ainda é incipiente e precisa de melhoras nos aspectos pedagógicos. Até mesmo conforme a LDB (BRASIL, 2007) aponta, a pós-graduação, mestrado e doutorado são responsáveis por preparar para a docência do Ensino Superior, no entanto, para Almeida (2012) e Joaquim, Boas e Carrieri (2013) isso não é formar, apontando que tal preparação não é o suficiente.

Em virtude disso, surgem algumas ações estratégicas nos programas e cursos para solucionar esse deficit formativo, a implantação de disciplinas de cunho didático-pedagógico e o estágio de docência. Entretanto sabemos que não é uma tarefa fácil o desenvolvimento com êxito dessa formação almejada e muitas são as críticas existentes frente a essas estratégias, bem como o descrédito dos cursos de pós-graduação, para inseri-las no currículo.

A pesquisa de Baibich-Faria et al. (2010) revela que os coordenadores de programas de pós-graduação em Educação da região sul do Brasil não apresentam uma concepção homogênea sobre a importância da formação em nível de pós-graduação para o exercício da docência no Ensino Superior. Em suma, tal pesquisa compreendeu, de acordo com os coordenadores: a) os programas podem ser um espaço de formação docente, mas não apresentam cultura e responsabilidade; b) o objetivo dos programas é a pesquisa e sua proposta curricular é coerente com essa missão; c) a docência no Ensino Superior não é objetivo prioritário. Em virtude disso, esses autores ainda apontam que, conforme as políticas atuais do país, os programas não podem objetivar apenas a formação docente para o Ensino Superior, entretanto os eximem da responsabilidade da preparação pedagógica para tal atuação.

Reconhece a necessidade do desenvolvimento investigativo na formação de mestres e doutores, dessa forma, em nenhum momento este estudo se faz contra ela, entretanto almejamos a reflexão da necessidade da implementação de uma formação pedagógica 
também, a qual proporcionará aos futuros professores uma formação que sustente sua prática docente. Desejo de muitos autores que discutem a docência no Ensino Superior, como Cunha (2014), que considera para a função de docência e de pesquisa uma formação específica e permanente, em virtude disso clama-a para reformulação, principalmente nos aspectos didático-pedagógicos, na formação dos professores universitários, principalmente esses jovens iniciantes.

Reconhecemos que há um movimento de criação de disciplinas didático-pedagógicas e o estágio de docência nos programas de pós-graduação, bem como Masetto (2015a) ainda sugere outras formas, além dessas: parcerias dos programas de Educação com os demais cursos, possibilitando disciplinas optativas na área de formação docente; organização de seminários, workshops ou encontros sobre novas experiências pedagógicas desenvolvidas no ensino superior.

No entanto, ao olhar os aspectos normativos, apenas as horas disponibilizadas nas disciplinas didático-pedagógicas e o estágio de docência são insuficientes para formar professores, pois tal função é inerente aos aspectos de ensino, pesquisa e extensão, bem como todas as atribuições que nelas são exigidas. Desse modo, a formação para atuação no Ensino Superior não está relacionada apenas às questões pedagógicas, mas trata-se de algo maior, uma formação integral, considerando que os cursos de pós-graduação lato sensu e stricto sensu apresentam lacunas nesses aspectos, principalmente nas questões pedagógicas.

Essa fragilidade não prejudica apenas os aspectos da prática pedagógica do professor em sala de aula, mas o pensar a formação profissional como um todo, na construção de um currículo do curso que leciona, bem como ações que lhe são associadas. Esse mesmo professor que apresenta conhecimento restrito sobre os aspectos didático-pedagógicos irá construir e reformular o currículo do curso, estará envolvido na (re)construção e discussão do Projeto Pedagógico do Curso - PPC e da matriz curricular, envolver-se-á nas discussões e decisões do Núcleo de Docentes Estruturante - NDE dentre outras atividades que necessita de conhecimento. Esse cenário é um fator preocupante, principalmente entre os estudiosos e professores que buscam a melhoria do ensino em IES. Cunha (2014, p. 29) retrata essa angústia numa de suas obras que discutem sobre o desenvolvimento profissional de professores universitários:

[...] na visão de dirigentes acadêmicos, as atividades de ensino e pesquisa acontecem de forma concomitante na universidade, mas não como a condição que a indissociabilidade prevê. Certamente essa perspectiva está também atrelada à escassa compreensão da centralidade do conhecimento na organização dos currículos dos cursos, explicitando a fragilidade tanto no campo epistemológico 
como no campo pedagógico. Considerando que são os docentes universitários que assumem postos de organização dos projetos curriculares de cursos ao mesmo tempo que decidem sobre as práticas de ensino e aprender que constituem suas aulas, essa situação é preocupante [...].

A partir dessa perspectiva, consideramos a importância dos conhecimentos didáticopedagógicos, bem como de currículo para os professores atuantes no Ensino Superior, que lhes permitem: compreender o processo formativo como um todo; além de tomar decisões coerentes sem prejudicar a formação de futuros profissionais. As IES também apresentam o papel de responsabilidade por esse cenário problemático sobre as questões pedagógicas dos professores, pois percebemos ausência de formação continuada que sustentem a prática docente do Ensino Superior, principalmente quando falamos dos aspectos inerentes ao ensino. Essa formação permite ao docente refletir sobre sua prática, ainda mais, contribui para o seu desenvolvimento profissional, consequentemente, para (re)construção das suas identidades.

Atualmente, vem se discutindo sobre as questões pedagógicas no Ensino Superior, principalmente em eventos científicos e obras literárias (livros, artigos), bem como em relatórios de pesquisa. Dentre esses materiais produzidos relatam-se experiências de formação continuada, por exemplo, a obra de Almeida (2012) que faz referência às experiências de formação e profissionalização de professores universitários, expondo especificamente a realidade da Universidade de São Paulo - USP, Universidade Autônoma de Barcelona, Universidade de Barcelona, Universidade Politécnica de Catalunha e Universidade de Alicante. Por fim, identificou que havia uma perspectiva comum entre elas referente à importância que a instituição atribuiu à formação pedagógica dos professores, visando à qualidade do ensino.

Há outra obra organizada por Cunha (2014) que aborda memórias, experiências, desafios e possibilidades sobre as estratégias institucionais para o desenvolvimento profissional docente e as assessorias pedagógicas universitárias. Essa obra é composta por dez estudos, apontando sobre a realidade de universidades em distintos estados brasileiros, destacando: Rio Grande do Sul, Santa Catarina, Paraná, Bahia e Amazonas. Ao final dessa obra, verificou que as políticas públicas influenciam nas ações acadêmicas associadas à qualidade do ensino e condições da docência, bem como às avaliações externas; o entendimento referente à docência e formação pedagógica foram se modificando e se transformando com o passar do tempo. Cunha (2014) também apontou alguns impasses, como: 
- a fragilidade de uma cultura institucional que reconheça lugares legitimados para o exercício da pedagogia universitária;

- o não reconhecimento da necessidade de saberes pedagógicos para docência universitária e a pós-graduação não se responsabilizam por essa formação;

- a carreira docente no Ensino Superior privilegia os produtos da pesquisa em detrimento do ensino;

- a ausência de compreensão sobre o lugar de fomento pela pedagogia universitária institucional;

- a preocupação com o pessoal apto para realização da assessoria pedagógica na universidade.

A partir dessas experiências, outras universidades sentem-se estimuladas, bem como os demais espaços que promovem a formação superior, a investirem em cursos, capacitações, minicursos, dentre outros modos que possam auxiliar o docente a enfrentar a realidade da sala de aula, além de proporcionarem um ensino de qualidade aos futuros profissionais. Em contrapartida, há falha de continuidade dessa formação nas universidades, sobretudo quanto à mudança de gestão. Tal realidade é comum em universidades públicas e privadas, pois a cada quatro ou oito anos ocorre mudança da equipe diretiva, o que apresenta dificuldades no prosseguimento de projetos das gestões anteriores em virtude das distintas perspectivas sobre o ensino, pesquisa e extensão.

Na perspectiva de Almeida (2012), as universidades devem proporcionar formação continuada aos seus professores, pois, a partir dessa ação, possibilitar-lhes-ão refletir de forma pedagógica e didática sobre o ensino e o aprender, fundamentados em teorias, conceitos e recursos adequados. Além disso, a autora acredita que essa formação contribui na construção da identidade docente, bem como para o desenvolvimento profissional dos professores universitários, sustentado numa perspectiva crítica com o contexto histórico, social, cultural e organizacional onde leciona. Masetto (2015a) parte da mesma concepção de Almeida (2012), mas considera importante a possibilidade da IES criar atividades que interessam ao grupo de professores, podendo também utilizar as estratégias de reunir pequenos grupos, possibilitando-lhes leituras individuais, estudos em grupos, trocas de email e experiências com seus pares.

A formação de um professor que atua no Ensino Superior, entretanto, ultrapassa as barreiras de sala de aula, num contexto formativo. O docente, na condição de pessoa, traz consigo uma bagagem - valores, expectativas, crenças e perspectivas - que contribui para sua forma de pensar uma atividade aos estudantes, bem como de se comunicar e compreender 
o ser humano, ou seja, olhar seu estudante como um ser pensante, provido de sentimentos e que carrega consigo uma história de vida. Os cursos de pós-graduação poderão contribuir para o professor pensar e trabalhar esses aspectos pessoais em sala de aula junto aos estudantes, mas não irão fazê-lo acreditar na solidariedade, cuja trajetória de vida nunca contribuiu de forma solidária e com alteridade.

Não é possível separar a pessoa do professor da do profissional professor, suas identidades estão atreladas uma à outra. Ao longo das experiências vivenciadas nesses dois aspectos, pessoal e profissional, o docente vai construindo e reconstruindo suas identidades. Esses fenômenos vão acontecendo ao longo da carreira profissional, possibilitando-lhe o desenvolvimento.

Em virtude dessa relação pessoal e profissional, Zabalza (2004) aponta um dilema sobre o sentido ou direção a ser tomada na formação dos professores, isto é, deve estar associada ao desenvolvimento pessoal ou à formação para resolução das necessidades da instituição. Na perspectiva do autor, a solução seria encontrar um equilíbrio, pois há necessidade de proporcionar formações nesses dois aspectos norteadores. Além desses dilemas citados, o autor aponta algumas questões que norteiam os impasses enfrentados nesse tipo de formação docente, assim organizados no Quadro 2.

Quadro 2-Dilemas na formação de professores universitários

\begin{tabular}{|c|c|c|}
\hline Eixo & Questões & Dilemas \\
\hline \multirow{3}{*}{$\begin{array}{l}\text { Sentido e } \\
\text { relevância da } \\
\text { formação }\end{array}$} & \multirow{3}{*}{$\begin{array}{l}\text { Que tipo de formação? } \\
\text { Formação para quê? }\end{array}$} & $\begin{array}{c}\text { Entre uma formação para o desenvolvimento } \\
\text { pessoal ou uma formação para resolução das } \\
\text { necessidades da instituição }\end{array}$ \\
\hline & & $\begin{array}{l}\text { Entre a obrigatoriedade e a voluntariedade de } \\
\text { formação }\end{array}$ \\
\hline & & $\begin{array}{l}\text { Entre a motivação intrínseca e a motivação pelo } \\
\text { reconhecimento }\end{array}$ \\
\hline \multirow{4}{*}{$\begin{array}{l}\text { Conteúdo da } \\
\text { formação }\end{array}$} & \multirow{4}{*}{ Formação em quê? } & $\begin{array}{l}\text { Entre formação generalista (tipo pedagógica) e } \\
\text { de formação específica e vinculada à própria } \\
\text { área de conhecimentos }\end{array}$ \\
\hline & & $\begin{array}{c}\text { Entre a formação a docência e formação para a } \\
\text { pesquisa }\end{array}$ \\
\hline & & $\begin{array}{c}\text { Entre a formação para o ensino ou para a } \\
\text { aprendizagem }\end{array}$ \\
\hline & & $\begin{array}{l}\text { Sobre a formação para tarefas de gestão, de } \\
\text { relações externas etc. }\end{array}$ \\
\hline \multirow{2}{*}{$\begin{array}{l}\text { Destinatários } \\
\text { da formação }\end{array}$} & \multirow{2}{*}{ Formação para quem? } & $\begin{array}{l}\text { Formação específica para novatos ou formação } \\
\text { para todos }\end{array}$ \\
\hline & & $\begin{array}{c}\text { Da problemática específica dos professores } \\
\text { associados e substitutos }\end{array}$ \\
\hline
\end{tabular}




\begin{tabular}{|c|c|c|}
\hline & & $\begin{array}{c}\text { Das diferentes culturas existentes entre os } \\
\text { professores e o pessoal administrativo e } \\
\text { gerencial da universidade } \\
\end{array}$ \\
\hline \multirow{4}{*}{$\begin{array}{l}\text { Agentes da } \\
\text { formação }\end{array}$} & \multirow{4}{*}{ Quem deve ministrá-la? } & Da responsabilidade da formação \\
\hline & & $\begin{array}{l}\text { Do debate sobre as competências dos } \\
\text { formadores }\end{array}$ \\
\hline & & Da Formação com pessoal próprio e alheio \\
\hline & & Da Profissionalização dos formadores \\
\hline \multirow{4}{*}{$\begin{array}{l}\text { Organização } \\
\text { da Formação }\end{array}$} & \multirow{4}{*}{$\begin{array}{l}\text { Que modelos e } \\
\text { metodologias são mais } \\
\text { eficazes? }\end{array}$} & $\begin{array}{l}\text { Entre a formação fundamentada nos sujeitos ou } \\
\text { em grupo ou unidades funcionais }\end{array}$ \\
\hline & & $\begin{array}{c}\text { Entre iniciativas de formação no curto prazo } \\
\text { (cursos, oficinas, etc.) e no médio e a longo } \\
\text { prazo (programas, sistemas de credenciamento } \\
\text { específico etc.) }\end{array}$ \\
\hline & & $\begin{array}{c}\text { Das diversas modalidades de formação e suas } \\
\text { contribuições }\end{array}$ \\
\hline & & $\begin{array}{c}\text { Das vantagens dos modelos democráticos e } \\
\text { participativos sobre os modelos centralizadores } \\
\text { nos processos de formação dos professores } \\
\text { universitários }\end{array}$ \\
\hline
\end{tabular}

Fonte: Adaptado de Zabalza (2004, p. 146-168)

A partir do exposto no quadro, observamos a dimensão de conflitos que contornam a formação de professores universitários, constatando a complexidade de processo vivido pelos docentes, bem como pela instituição que promove essa formação. Assim, entendendo-se como um desafio às universidades e, conforme Zabalza (2004), independente da caminhada norteadora escolhida, é importante que se promova uma orientação que permita ao docente tornar-se um profissional da “aprendizagem”. Isto é, levar à compreensão de que é preciso desenvolver uma formação que contribua para o desenvolvimento de uma prática docente, sustentada num aspecto pedagógico, afastando a postura de especialista de determinado conteúdo. Em virtude disso, viu-se a necessidade de um segundo tópico no capítulo, que explora a prática pedagógica dos professores universitários, assim permitindo a continuação e reflexão sobre a docência na formação de profissionais do Ensino Superior.

\subsection{PRÁTICA PEDAGÓGICA NA DOCÊNCIA UNIVERSITÁRIA: ESTADO DA ARTE}

Não é novidade a necessidade de repensar o papel do docente na universidade, além de sua prática pedagógica (CUNHA, 2014). Em virtude disso, dos impasses e dos dilemas sobre a formação dos professores universitários, este tópico possibilitará repensar de forma reflexiva, apontando pensamentos e perspectivas de autores que discutem a prática pedagógica de forma geral, bem como aqueles que a abordam no Ensino Superior, assim 
como na própria Universidade. Essa discussão será realizada concomitantemente à análise das informações coletadas no estado da arte, disposta na introdução desta tese, entretanto neste item serão apontadas e discutidas as bases teóricas utilizadas nas 58 pesquisas selecionadas no BDTD. Para compreender esse universo exposto, optou-se por definir a prática docente, a prática pedagógica, dessa forma auxiliará no entendimento de toda a discussão do tópico. Tal postura surge a partir da percepção sobre as diferentes concepções acerca da prática pedagógica, principalmente sua clareza conceitual. Essa inquietação também foi apontada por Maria Amélia do Rosario Santoro Franco, que escreveu um capítulo intitulado: "Práticas pedagógicas nas múltiplas redes educativas" inserido no livro - Temas de Pedagogia: diálogos entre didática e currículo - de José Carlos Libâneo e Nilda Alves, em 2012, e o artigo: "Prática pedagógica e docência: um olhar a partir da epistemologia do conceito" na Revista Brasileira de Estudos Pedagógicos, no ano de 2016. Essas obras auxiliam no entendimento conceitual da prática docente e da pedagógica.

As exigências para a prática docente independem da política ou ideologia do professor. As exigências para ensinar não estão associadas apenas ao papel do docente ao ministrar o conteúdo, mas ao pensar certo, permitindo que o professor consiga mostrar ao estudante a beleza de estar no mundo e com o mundo, como seres históricos, tendo a capacidade de intervir no mundo e conhecê-lo. Freire (2015, p. 34) enfatiza que "[...] transformar a experiência educativa em puro treinamento técnico é amesquinhar o que há de fundamentalmente humano no exercício educativo: o caráter formador".

Isso leva à compreensão de que a prática docente pode estar alicerçada a fundamentos pedagógicos, como ao contrário, o professor pode desenvolver uma prática a qual não está sustentada por uma perspectiva teórica quanto aos aspectos didático-pedagógicos. No momento em que as preocupações estão centradas no ensino de forma técnica e mecânica das ações na construção do conhecimento, associamos a falta de base pedagógica a essa prática. Entretanto, no momento em que o professor repensa e reflete sua prática docente, buscando a formação humana, conseguirá alcançar uma prática pedagógica. Isto é, sua ação deverá fundamentar-se numa intencionalidade, que atenda expectativas educacionais solicitadas/requeridas pela comunidade à qual está socialmente inserida. Logo, toda prática pedagógica é uma prática docente, mas nem toda prática docente é uma prática pedagógica (FRANCO, 2012; 2016).

[...] nas práticas pedagogicamente construídas, há a mediação do humano e não a submissão do humano a um artefato técnico previamente construído [...] a prática pedagógica quando incorporar a reflexão contínua e coletiva, de forma a assegurar 
que a intencionalidade proposta é disponibilizada a todos; será pedagógica à medida que buscar a construção de práticas que garantam que os encaminhamentos propostos pelas intencionalidades possam ser realizados (FRANCO, 2016, p. 536).

A concepção de prática pedagógica, entretanto, está imbricada em algumas bases teóricas norteadoras, as quais permitirão olhá-la e entendê-la de forma distinta ao longo da prática docente e a partir da compreensão pedagógica adquirida (VERDUM, 2013; FRANCO, 2016). Em virtude disso, Franco (2016) descreve duas vertentes de racionalidade pedagógica, presentes no contexto educacional: a técnico-científica e a crítico-emancipatória. A primeira está sustentada pela perspectiva positivista, numa vertente evolucionista, pragmática, tecnicista e behaviorista, com uma visão mecanizada do mundo e de uma concepção naturalista do homem, que influencia na educação quanto aos aspectos laicos, disseminando os valores burgueses, a fim de normatizar e prescrever a prática para fins sociais relevantes. A segunda fundamenta-se em Marx e Engels, pelo princípio básico da historicidade, na condição de compreensão do conhecimento. Além disso, valorizamos a formação humana enquanto condição "de superação da opressão, submissão e alienação, do ponto de vista histórico, cultural ou político" (FRANCO, 2016, p. 540).

Este estudo parte da compreensão de que a prática pedagógica ultrapassa a barreira de uma prática técnica, norteada pela concepção crítico-emancipatória. Será respeitada, entretanto, a realidade existente, principalmente no Ensino Superior, pois constatamos que ainda há resistência à mudança de perspectiva dos docentes, cuja formação está sustentada em práticas a partir de concepção técnico-científica, denominada por muitos teóricos como tradicional, na qual predominam os procedimentos metodológicos, prescritos e planejados pelos professores antecipadamente, seguindo para a execução. Dessa forma, visa à instrução e repasse de informações, entendendo que o estudante é neutro e aprenderá ouvindo o professor e realizando as atividades previstas (FRANCO, 2011).

Paulo Freire, cujas discussões não estavam centradas no Ensino Superior, faz alguns apontamentos interessantes sobre essa fase formativa. Crítica, nesse caso, a forma de conduzir a prática docente a partir da concepção técnico-científica e considera admirável se a universidade deixasse de proporcionar o ato de ensinar e aprender de forma mecanizada e se tornasse um local de produção de conhecimento. Ainda julga que as universidades brasileiras só irão alcançar os objetivos almejados no momento em que seus docentes se tornarem educadores, deixando de ser meros transmissores de comunicados (FREIRE, 2008; 2014). Portanto, parte-se do pressuposto de que "não há docência sem discência [...] onde quem ensina aprende ao ensinar e quem aprende ensina ao aprender" (FREIRE, 2015, p. 25). 
Percebemos que a prática docente universitária, principalmente, vive dicotomicamente entre essas duas perspectivas, encontrando-se numa única instituição professores e gestores que apoiam uma prática na concepção crítico-emancipatória, bem como aqueles que nutrem suas práticas com aspectos técnico-científicos. Tal situação não é restrita ao professor universitário, verificamos nos estudos de Verdum (2013) e Martins, Moraes e Santos (2014) que os professores da Educação Básica também precisam superar essa concepção em que a prática pedagógica está imbricada na transmissão do conhecimento e o aluno tem papel passivo na própria formação. As duas pesquisas revelaram nos discursos dos professores características de que suas perspectivas sobre a prática pedagógica estão sustentadas numa visão técnica do ensino.

No estudo de Moletta (2013) com professores universitários de Educação Física de duas universidades de Santa Catarina (pública e comunitária), no entanto, observamos estratégias de mudanças nas práticas pedagógicas ao longo de sua experiência docente, mas ainda há fortes características técnico-científicas nelas impregnadas. Essa realidade, também identificada no estudo de caso realizado por Miranda (2010) com professores Educação Física que atuam na formação inicial e continuada, bem como em outros campos de intervenção da área, na região da cidade de Curitiba.

A prática pedagógica pode ser entendida também como uma prática social, a fim de concretizar os processos pedagógicos (FRANCO, 2012). Consequentemente, a prática docente universitária precisa ser considerada "uma prática social historicamente construída, condicionada pela multiplicidade de circunstâncias que afetam o docente, realiza-se como práxis, num processo dialético que, a cada momento, sintetiza as contradições da realidade social em que se insere" (FRANCO, 2011, p. 167).

O desenvolvimento da prática pedagógica crítica, que esperamos seja realizada pelos professores universitários, está fundamentada em três princípios basilares: a) intencionalidade previamente estabelecida, a qual sustenta o processo didático utilizando formas e meios variados; b) resistências e desistências, à luz da dialética, pulsional e totalizante; c) historicidade, associada à tomada de decisões, de posições e se transformam pelas contradições. O docente, respaldado nesses princípios, precisa desenvolver o diálogo, o ser crítico e reflexivo e obter consciência da intenção de sua prática (FRANCO, 2016).

Em virtude disso, realizamos um estudo sobre o estado da arte buscando identificar as investigações desenvolvidas em programas e cursos de pós-graduação stricto sensu que discutem a prática pedagógica dos professores do Ensino Superior. Utilizamos como base de dados a biblioteca digital de teses e dissertações - BDTD, com os descritores: "Prática 
Pedagógica" (busca em todos os campos utilizando todos os termos) e "Ensino Superior" (busca em assunto utilizando todos os termos). O período de coleta foi a partir de 2012 a 2017, postados até 25 de maio, foram encontrados 309 trabalhos (192 dissertações e 117 teses - Tabela 5). Para a seleção de análise foram utilizados critérios de inclusão, quais foram: a) abordar sobre a prática docente e/ou prática pedagógica sobre professor do Ensino Superior; b) pesquisas que buscaram contextualizar a prática docente e/ou prática pedagógica no contexto amplo, não se preocupando com um conteúdo específico a ser trabalhado; c) investigações com professores e estudantes do Ensino Superior, bem como documentos relacionados a esse grau de ensino.

Tabela 5 - Resultado da análise de dissertações e teses do BDTD de 2012-2017

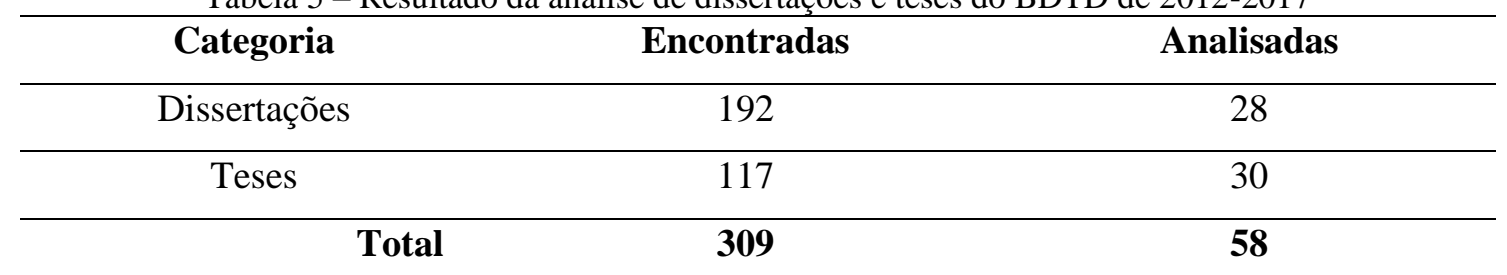

Fonte: Elaborada pela pesquisadora (2017)

A partir da seleção realizada foram analisadas 58 dissertações e teses (tabela 5), foram identificados o ano de publicação e região do país. O ano de 2014 apresentou maior número de trabalhos $(n=16)$ e em 2017, até o período definido não foi postado nenhum trabalho que se enquadrou nos critérios da pesquisa. Os demais anos apresentaram quantidades que se equiparam: $2013(n=13), 2015(n=12)$ e $2016(n=10)$. Conforme a região do país, identificamos a maior incidência de trabalhos analisados dentro dos parâmetros na região sudeste $(n=39)$ e sul $(n=17)$ (Tabela 6). A justificativa para tal resultado se dá porque as duas regiões apresentam maior número de programas e cursos de pós-graduação stricto sensu do Brasil, de acordo com os dados registrados na Plataforma Sucupira (2018a).

Tabela 6 - Dissertações e Teses analisadas distribuídas por ano; região do país

\begin{tabular}{|c|c|c|c|}
\hline Categoria & $\mathrm{N}^{\mathrm{o}}$ & Categoria & $\mathrm{N}^{\mathrm{o}}$ \\
\hline Ano Publicação & & Região do Programa & \\
\hline 2012 & 07 & Norte & 02 \\
\hline 2013 & 13 & Nordeste & 06 \\
\hline 2014 & 16 & Centro-Oeste & 02 \\
\hline 2015 & 12 & Sudeste & 32 \\
\hline 2016 & 10 & Sul & 16 \\
\hline
\end{tabular}

Fonte: Elaborada pela pesquisadora (2017)

Quanto ao caráter institucional, observamos a predominância nas IES pública $(n=42)$, isso também é decorrente da concentração dos programas e cursos inseridos em 
universidades públicas (federal e estadual), totalizando $80,8 \%(n=3.47,2)$ referentes ao ano de 2017 (GEOCAPES, 2018). Enquanto a distribuição dos trabalhos, de acordo com a área específica que cada programa e curso contemplavam, também foi alvo de análise, o que permitiu identificar a concentração na Educação, ou seja, programas e cursos de pósgraduação em Educação $(n=36)$. Também destacou programas da área de concentração da Saúde como: Enfermagem (n=6) e Educação Física (n=2). Houve outros programas e cursos que envolveram as seguintes ciências: biológicas, humanas, aplicadas, sociais, exatas e da terra.

Ao olhar as informações dispostas nos trabalhos, verificamos discussões sobre o desenvolvimento profissional; a formação pedagógica; identidade docente; a prática docente; e a prática pedagógica. Dentre elas abordavam aspectos inerentes à prática do professor do Ensino Superior: estratégias de ensino; perspectiva docente; saberes; competências; formação continuada favorecendo a formação pedagógica na IES; a formação para docência na pós-graduação; fundamentos que norteiam suas práticas, dentre outros.

Ao longo da análise das dissertações e teses, observamos a distinção de autores utilizados para sustentá-las teoricamente, compreender e discutir sobre a prática pedagógica dos professores do Ensino Superior, entretanto todos partem do princípio de uma prática crítica e reflexiva. Salientamos ainda que os maiores números de indicações foram: Selma Pimenta $(\mathrm{n}=21)$ e Léa Anastasiou $(\mathrm{n}=14)$. Além dessas autoras, sempre foram empregados, em conjunto, outros autores, indicados na nuvem de palavras (Figura 2). Isso porque as autoras são pesquisadoras específicas da área da pedagogia universitária, ainda que sustentem suas investigações em outros pensadores que estudam exclusivamente o fenômeno da prática docente e suas vertentes.

A figura 3 aponta os autores mais citados nos trabalhos analisados, representados de acordo com a dimensão do sobrenome do autor (quanto maior, mais citado). Ainda se revelaram com mais evidência nos trabalhos os autores que desenvolvem pesquisas específicas na docência universitária: Maurice Tardif, Antonio Nóvoa, Marcos Masetto, Maria Isabel da Cunha, Maria Isabel de Almeida, Ilma Passos Alencastro da Veiga, Miguel A. Zabalza etc. Também foi identificada a utilização de autores com concepções mais amplas sobre a prática docente e o que a contorna, como: Donald Schön, Paulo Freire, Antonio Nóvoa, José Carlos Libâneo etc. Além dos autores mencionados na Figura 2, também foram utilizados outros pesquisadores da área, mas optou-se por apontar aqueles que obtiveram mais de uma menção dentre os trabalhos investigados. 
Figura 2 - Nuvem de palavras referente aos autores mais indicados como base teórica

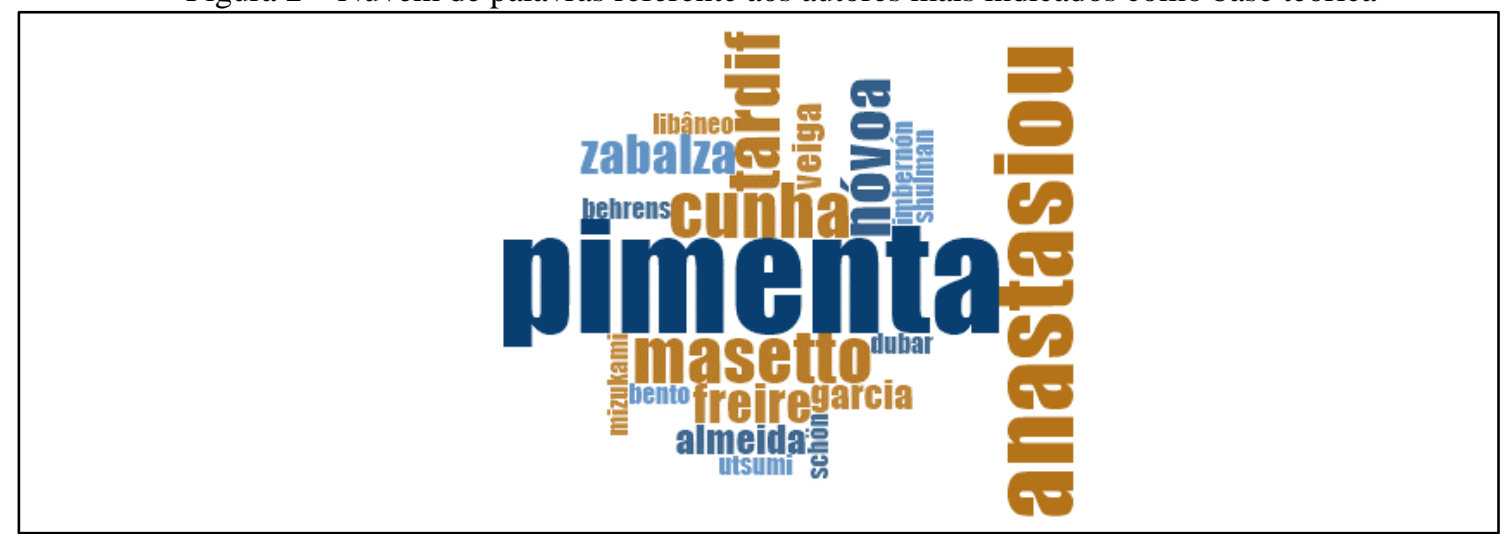

Fonte: Elaborada pela pesquisadora (2018)

O autor Claude Dubar, entretanto, foi citado duas vezes, em virtude do resultado encontrado, o presente estudo apresentou uma abordagem teórica para compreensão da prática pedagógica distinta das demais dissertações e teses apresentadas entre os anos de 2012 a 2017. Verificamos que alguns trabalhos abordaram a prática pedagógica no Ensino Superior a partir da perspectiva da prática reflexiva dos autores Schön e Freire. Além disso, Zeichner também foi citado juntamente com Schön. Assim, compreendemos que a prática docente, num aspecto reflexivo, contrapõe a visão de uma prática técnica, pois a reflexão exige condições para análise crítica e criação de formas de trabalho coletivo no ambiente de ensino, seja escola, universidade etc., além de permitir ao docente refletir sobre sua prática, seu fazer, seu pensar educativo, suas condições de trabalho, sua identidade profissional, dentre outros aspectos. Existem alguns autores que discutem essa concepção como: John Dewey, utilizando o termo de pensamento reflexivo; Kenneth Zeichner com ensino reflexivo; e Donald Schön a partir da prática reflexiva (DORIGON; ROMANOWSKI, 2008). Além desses autores, o próprio Zeichner (2008) inclui mais dois autores que descrevem sobre professores reflexivos: Paulo Freire e Jurgen Habermas, compreendendo que:

A prática reflexiva proporciona aos professores oportunidades para seu desenvolvimento profissional e pessoal, tornando-os profissionais mais conscientes de si, ajudando-os a libertarem-se de comportamentos impulsivos e rotineiros, permitindo-lhes agir de forma intencional, distinguindo-os como seres humanos informados, sendo esta uma característica da ação inteligente (DORIGON; ROMANOWSKI, 2008, p. 17).

Quanto ao Ensino Superior, na perspectiva de Libâneo (2009) para alcançar a formação do profissional que se almeja, é necessário um ensino que promova o desenvolvimento das capacidades e habilidades de pensar dos alunos. Ou seja, o estudante precisa pensar na realidade e intervir nela, a partir de uma formação cultural e científica e o 
docente carece auxiliar o estudante a pensar, raciocinar e utilizar o conhecimento adquirido. É importante que o docente enfatize o processo de aprendizagem como "um processo de crescimento e desenvolvimento de uma pessoa em sua totalidade abarcando minimamente quatro grandes áreas: a do conhecimento a do afetivo-emocional, a de habilidades e de atividades, ou valores" (MASETTO, 2015a, p. 46).

Alguns professores, contudo, focalizam nas aulas pontos de suas pesquisas, ofuscando o conhecimento necessário que o estudante deve atribuir ao processo de ensino e aprendizagem (CUNHA, 2014). A docência do ensino superior, por muito tempo, veio enfatizando apenas o processo de ensino, esteve centrada na transmissão e na comunicação oral, sem contar com a organização curricular fechada, a qual apresenta componentes curriculares com características conteudistas e técnicas, com pouca interdisciplinaridade, discussões com temas transversais e incentivo à investigação científica (MASETTO, 2015a). Isso induz a um processo de divisão de funções: o docente promove o ensino e fica a critério do aluno a aprendizagem. Nesse contexto, o professor não apresenta preocupações com o estudante no seu modo de aprender, partindo do pressuposto de que o fracasso está associado à falta de interesse, conhecimento, até mesmo de capacidade (ZABALZA, 2004).

Este estudo não vem generalizar, muito menos minimizar o papel do docente no processo formativo, o qual é basilar, mas compreender a realidade enfrentada pelos professores universitários, bem como a do Ensino Superior em geral, independente se estão preparados para atuarem na formação profissional ou não. Há evidências de hábitos estudantis carregados de aspectos intrínsecos, os quais ultrapassam os fatores extrínsecos proporcionados por professores, colegas de turma e instituição e podem estar relacionados aos fatores do eu-pessoal, formação anterior, família etc. Tais fatores podem levar à conduta de ausência de interesse, motivação e comprometimento; ao individualismo e interesse com a nota e passar na disciplina; aos hábitos insuficientes de estudo; à dificuldade de interpretação, redação, leitura, raciocínio lógico e criatividade; à ausência de clareza da área de conhecimento; sentirem-se pertencentes à comunidade, dentre outros motivos.

Pachane (2009), no entanto, considera que o processo de massificação dentro das Universidades pode causar essa realidade encontrada entre os estudantes, pois há uma heterogeneidade do público estudantil, além das exigências e condutas impostas pela sociedade capitalista vivida, a qual faz com que os estudantes ingressem na formação profissional sem preparo e sustentação nos aspectos emocionais e/ou intelectuais. Também a inserção de um público jovem acarreta imaturidade quanto a assumir compromisso na formação inicial com responsabilidade e consciência. 
Esses jovens estudantes possuem atributos adquiridos ao longo da trajetória formadora, principalmente do Ensino Médio, quando são preparados para a memorização do conteúdo, de modo que possam realizar a prova de vestibular. Esse contexto leva-os ao comportamento fundamentado na lógica da exclusão, à pouca criticidade, voltados apenas ao produto (vestibular) (PIMENTA; ANASTASIOU, 2010). Isto é, a formação dos estudantes está pautada numa perspectiva não reflexiva, à luz de conhecimentos imediatos e técnicos, que os leva à ausência de compreensão nas tomadas de decisões dos professores no Ensino Superior e suas práticas.

Assim, compreendemos a importância dos papéis dos estudantes e dos professores no processo formativo, ambos os envolvidos precisam tomar consciência e assumir suas responsabilidades dentro desse contexto. É atribuição, contudo, da instituição e do docente construir um ambiente de formação profissional à luz da formação de cidadãos capazes de participarem da vida política, social e econômica, contrapondo a ideia de diferenças e competição (BRAGA; FAGUNDES, 2015). Em razão de que, ao longo da trajetória formativa, o acadêmico vai se construindo profissionalmente, a partir das experiências vividas, relações estabelecidas, conhecimentos adquiridos, dentre outros aspectos que contribuem para a prática da práxis.

Dessa forma, esta pesquisa não minimiza o papel das IES e sua contribuição para uma prática pedagógica, pois a formação docente para o Ensino Superior apresenta lacunas nos conhecimentos necessários à docência como: a construção de um planejamento, organização da aula, metodologias e estratégias didáticas, avaliação, peculiaridades da interação professor-aluno dentre outros. Logo, as instituições deverão contribuir para o desenvolvimento profissional de seus professores, possibilitar-lhes formação que favoreça a prática docente norteada por aspectos pedagógicos e voltada ao processo de ensinoaprendizagem. Excluímos desse modo, a concepção da função docente de comunicador e transmissor de conteúdo, pré-determinado. Há necessidade de romper os hábitos do desenvolvimento de uma didática instrumentalizada, a qual contribui para uma formação acrítica e conservadora.

Os autores Almeida (2012), Pimenta e Anastasiou (2010) e Zabalza (2004) contrapõem essa perspectiva de didática instrumental, que norteou as dissertações e teses analisadas sobre a prática pedagógica do Ensino Superior. Esses pesquisadores consideram que o ensino carece de conhecimentos específicos, alicerçado numa formação pedagógica, a qual possibilita um processo contínuo de atualizações nas abordagens dos conteúdos e novas formas didáticas de ensinar. Reconhecem, entretanto, que há outros saberes e conhecimentos 
que sustentam a prática docente, os quais não se constroem exclusivamente na formação, mas sim nas relações, experiências e contextos vividos antes da própria formação inicial como: professores, familiares, escolas, atuação profissional, colegas, dentre outros.

O modo de considerar a prática pedagógica envolve a formação, os espaços-tempos, as opções da organização do trabalho docente, as parcerias, expectativas do docente, os impactos sociais e culturais do espaço e demais fatores que envolvem a docência. Assim, reconhece como uma prática, a qual excede os aspectos didáticos, pois utiliza a didática, bem como a transcende (FRANCO, 2016).

Este estudo compartilha das mesmas perspectivas de Almeida (2012), Pimenta e Anastasiou (2010) e Zabalza (2004) sobre a importância da formação pedagógica, bem como das vivências adquiridas ao longo da vida pessoal para o desenvolvimento de uma prática pedagógica. Considera, entretanto, que esses conhecimentos adquiridos ao longo da formação pessoal possibilitam à ação docente uma prática social, oportunizando construção do conhecimento específico para formação de profissionais, bem como a disposição de valores, crenças, perspectivas e expectativas aos jovens estudantes.

Além da perspectiva teórica identificada nos trabalhos do BDTD, também podemos compreender a prática pedagógica enquanto objeto investigativo, isto é, os resultados encontrados e suas considerações. Primeiramente, percebemos que os docentes participantes nesses estudos apresentaram uma concepção, de forma geral, tradicionalista sobre essa prática (termo utilizado na maioria das investigações). No entanto a concepção sobre a prática reflexiva também apareceu como uma prática utilizada entre os professores.

Em virtude da predominância dessa "prática tradicional", as considerações finais dos trabalhos aclamam pela perspectiva de uma prática reflexiva entre os docentes atuantes no Ensino Superior. Tal mudança está relacionada, pois as práticas pedagógicas apontadas estão associadas à supervalorização do conteúdo, utilização de aulas expositivas de forma constante sem mudanças de formato de aula, avaliações objetivas (devido aos exames externos). Isto é, o professor coloca-se numa posição de fonte de conhecimento, visto que os trabalhos consideram a necessidade de os professores reverem suas práticas, buscando uma perspectiva mais humanista, ações interdisciplinares, diferentes estratégias pedagógicas etc.

Além dessa problemática apresentada de forma comum entre os trabalhos, pudemos perceber que as experiências profissionais que excedem à docência no Ensino Superior surgem como ponto importante na construção da prática pedagógica, pois auxiliam o professor a relacionar a teoria e a prática, possibilitando exemplificar fatos correlacionados com o conteúdo abordado. As relações interpessoais, principalmente entre professor e aluno, 
também emergiram na contribuição das práticas, considerando como essencial o diálogo e o bom relacionamento com os discentes, pois reflete para o melhor desempenho no processo de ensino e aprendizagem.

Logo, percebe-se que há mudanças no cenário da prática pedagógica do Ensino Superior, na qual o docente deixa de ser o único agente do conhecimento, possibilitando ao estudante se tornar ativo no seu processo de aprendizagem. Isso só acontece a partir no momento em que os professores modificarem suas perspectivas sobre as próprias práticas, buscando novos conhecimentos por meio de capacitações, cursos, novas leituras, dentre outros. Do mesmo modo as instituições devem incentivar o desenvolvimento profissional de seus docentes, a partir de ações reflexivas sobre a prática e os aspectos que lhes são relacionados.

Também identificamos o tipo de pesquisa, tipo de coleta (instrumentos) e participantes. Isso mostrou que investigações de cunho qualitativo sobressaem em estudos sobre a prática docente e a prática pedagógica dos professores do Ensino Superior, assim como a utilização de estudos quantitativos não foi utilizada de forma única, no caso, sempre combinada com a pesquisa qualitativa.

No tipo de coleta, predominou a utilização de entrevista semiestruturada, concomitante à análise de documentos (planos de ensino; relatórios e projetos políticos dos cursos) e questionário com perguntas abertas e fechadas. Além disso, identificamos o recurso investigativo de observação de aulas e grupo focal.

Entre os participantes, predominaram professores do Ensino Superior, em paralelo também foram pesquisados discentes e egressos dos cursos de graduação, professores e estudantes de programas e cursos de pós-graduação, além de coordenadores de cursos (gestores). Como mencionado anteriormente, destacaram-se investigações nos cursos de enfermagem e de ciências contábeis, isso reflete na incidência de investigação com docentes atuantes nesses cursos. Entretanto identificamos estudos com abordagem ampla, ou seja, professores atuantes nos cursos da saúde, nos cursos de Licenciatura, nas engenharias, participantes de formações continuadas etc. Assim, a pesquisa envolveu diferentes cursos, possibilitando aos docentes dos cursos de Educação Física se inserirem em demais estudos.

Por fim, ao analisar esses trabalhos, identificamos que os estudos estão centrados em professores do Ensino Superior com diferentes tempos de carreira docente, constatando-se apenas seis docentes no início de carreira. Dessa forma, concluímos que há ausência de pesquisas que contemplem especificamente a prática pedagógica dos professores jovens doutores, bem como dos professores de Educação Física. Em virtude disso, justifica-se esta 
proposta de pesquisa como inédita, além da temática de suma importância a ser discutida no espaço científico, principalmente para a área da Educação Física. Quanto à escolha metodológica do estudo, corroboram investigações que abordam sobre a prática pedagógica, de modo a entender a veracidade dos estudos qualitativos, utilizando análise documental observação de aulas e entrevistas. 


\section{CAPÍTULO 2 \\ EDUCAÇÃO FÍSICA: PROFISSÃO E PROFISSIONALIZAÇÃO}

Este capítulo tem como objetivo descrever a Educação Física enquanto profissão e correspondente profissionalização. Inicia-se nas teorias de currículo, seguido de um breve retrato histórico, traçando principalmente o surgimento e o crescimento dos cursos de formação inicial e respectivos currículos. No segundo momento, discutimos sobre a formação continuada na área a partir da pós-graduação lato sensu e stricto sensu, cursos e programas de aperfeiçoamento e demais modalidades.

\subsection{O CURRÍCULO E AS FORMAÇÕES INICIAIS EM EDUCAÇÃO FÍSICA}

A discussão sobre currículo nas formações iniciais em Educação Física é complexa, primeiro pelo fato que são duas habilitações que buscam formação para diferentes espaços de trabalho, mas que apresentam uma base comum de conhecimento, as quais, por muito tempo, eram desenvolvidas juntas. Segundo aspecto que leva a essa dificuldade são as distintas perspectivas de estudiosos, profissionais e professores universitários que apresentam e defendem esse assunto. Em virtude disso, decidimos introduzir essa discussão a partir das teorias do currículo e suas concepções, seguindo as questões específicas existentes na área da Educação Física.

Este estudo defende a perspectiva de Silva (2010) cujas teorias não definem o conceito de currículo em si, mas permitem compreender sua perspectiva, partindo do pressuposto de que devem responder qual conhecimento deve ser ensinado. Os fatores que distinguem as teorias abordadas sobre a natureza humana, sobre a natureza da aprendizagem, sobre a natureza conhecimento, da cultura e da sociedade.

No momento em que a teoria do currículo atribui o conhecimento a ser ensinado, permite que ocorra uma seleção do conhecimento considerado importante, consequentemente, devemos pensar: que pessoa almejo formar a partir disso? No entanto tal questionamento é ofuscado, pois não há compreensão de que as teorias do currículo estão inter-relacionadas com a identidade ou a subjetividade (SILVA, 2010).

[...] na medida em que as teorias do currículo deduzem o tipo de conhecimento considerado importante justamente a partir de descrições sobre o tipo de pessoa que elas consideram ideal. Qual é o tipo de ser humano desejável para um determinado tipo de sociedade? Será a pessoa racional e ilustrada do ideal humanista de Educação? Será a pessoa 
otimizadora e competitiva dos atuais modelos neoliberais de Educação? Será a pessoa ajustada aos ideais de cidadania do moderno estado-nação? Será a pessoa desconfiada e crítica dos arranjos sociais existentes preconizada nas teorias educacionais críticas? [...] (SILVA, 2010, p. 15).

Percebemos, a partir dos questionamentos de Silva (2010), a influência do currículo na identidade da pessoa, pois, a partir das escolhas que o delineiam, a teoria permite a construção da subjetividade. Na perspectiva pós-estruturalista, esse ato de eleger o conhecimento está relacionado à questão do poder. No momento em que isso ocorre, fica determinada a identidade almejada, pois é privilegiado um conhecimento em detrimento do outro e, a partir desse ponto, diferem três grandes abordagens: teorias tradicionais; teorias críticas; teorias pós-críticas, dispostas no quadro 3 (SILVA, 2010).

Quadro 3 - Teorias do currículo suas características, principais modelos e autores

\begin{tabular}{|c|c|c|c|}
\hline $\begin{array}{ll} & \text { Teorias } \\
\text { Descrições } & \end{array}$ & Tradicionais & Críticas & Pós-Críticas \\
\hline Características & $\begin{array}{c}\text { Ensino } \\
\text { Aprendizagem } \\
\text { Avaliação } \\
\text { Metodologia } \\
\text { Didática } \\
\text { Organização } \\
\text { Planejamento } \\
\text { Eficiência } \\
\text { Objetivos }\end{array}$ & $\begin{array}{c}\text { Ideologia } \\
\text { Reprodução cultural } \\
\text { e social } \\
\text { Poder } \\
\text { Classe Social } \\
\text { Capitalismo } \\
\text { Relações sociais de } \\
\text { produção } \\
\text { Conscientização } \\
\text { Emancipação e } \\
\text { Liberdade } \\
\text { Currículo Oculto } \\
\text { Resistência }\end{array}$ & $\begin{array}{c}\text { Identidade, } \\
\text { alteridade e } \\
\text { Diferença } \\
\text { Subjetividade } \\
\text { Saber-poder } \\
\text { Representação } \\
\text { Cultura } \\
\text { Gênero, Raça, } \\
\text { Etnia, Sexualidade e } \\
\text { Multiculturalismo }\end{array}$ \\
\hline $\begin{array}{c}\text { Principais Modelos } \\
\text { e Pensadores }\end{array}$ & $\begin{array}{c}\text { Modelos } \\
\text { Tecnocráticos - } \\
\text { Bobbitt (1918) e } \\
\text { Tyler (1949) }\end{array}$ & $\begin{array}{c}1970 \text { - Paulo Freire; } \\
\text { Louis Athusser; } \\
\text { Pierre Bourdieu; } \\
\text { Jean-Claude } \\
\text { Passeron. }\end{array}$ & $\begin{array}{l}\text { Pós-Modernidade: } \\
\text { Perry Anderson } \\
\text { (década de1930); } \\
\text { Jean-François } \\
\text { Lyotard (1979) } \\
\text { Pós-Estruturalismo: }\end{array}$ \\
\hline
\end{tabular}




\begin{tabular}{|c|c|c|c|}
\hline Modelos & $1971-$ Baudelot e & Michel Foucault e \\
Progressistas - & Establet; Brasil & Jacques Derrida; \\
Dewey (1902) & Bernstein; Michael & Cleo Cherryholmes; \\
& Young. & Thomas Popkewitz \\
& 1976-Samuel & Pós-Colonialista: \\
& Bowles e Herbert & Frantz Fanon, Aimé \\
& Gintis; William & Césaire e Albert \\
& Pinar e Madeleine & Memmi (1950- \\
& Grumet & 1960) \\
& 1979- Michael & Estudos Culturais: \\
& Apple & Raymond Williams \\
& & (1958) e Richard \\
& & Hoggart (1957); \\
& & Michael Young \\
& & (1971); Henry \\
& & Giroux (1982) \\
\hline
\end{tabular}

Fonte: Adaptado de Silva (2006) e Silva (2010)

As teorias do currículo e correspondentes modelos permitiram compreendê-lo a partir de distintas perspectivas ao longo da história, incorporado, inicialmente, no século XIX e meados do século XX pela teoria tradicionalista fundamentada nos modelos teocráticos (Bobbit e Tyler) e progressistas (Dewey). Em seguida o currículo passou a ser pensado além das concepções técnicas relacionado ao ensino e eficiência, categorias de aprendizagem e desenvolvimento, grade curricular e lista de conteúdo, assim assumindo as teorias críticas. Tais quais apontam pioneiramente que o currículo é uma construção social, compreendendoo como resultado do processo histórico. A fim de ampliar e modificar alguns pontos dessas teorias, surgem os modelos teóricos pós-críticos, enfatizando que o currículo não pode ser entendido sem compreender primeiro as relações de poder, além de ampliar o olhar para as questões de dominação associada à raça, etnia, gênero e sexualidade. Essas teorias, críticas e pós-críticas, independentemente de suas particularidades, vieram nos apresentar que o currículo é uma questão de saber, identidade e poder (SILVA, 2010).

Em suma, depois das teorias críticas e pós-críticas, não podemos mais olhar para o currículo com a mesma inocência de antes. O currículo tem significados que vão muito além daqueles aos quais as teorias tradicionais nos confinaram. O currículo 
é lugar, espaço, território. O currículo é relação de poder. O currículo é trajetória, viagem, percurso. O currículo é autobiografia, nossa vida, curriculum vitae, no currículo se forja nossa identidade. O currículo é texto, discurso, documento. O currículo é documento de identidade (SILVA, 2010, p. 150).

Em virtude de a contextualização exposta corroborar a perspectiva sobre currículo defendida por Silva (2010), consideramos importante conhecer e entender a relação do saber, identidade e poder que constituiu o currículo na formação de profissionais de Educação Física ao longo da trajetória histórica. Sabemos que a Educação Física enquanto profissão, no Brasil, caminhou juntamente com as mudanças ocorridas na sociedade, ciência, política e cultura, como qualquer outra profissão. Sua história é composta de pluralidade, pois atinge distintos campos do saber e envolve diferentes interesses políticos e econômicos, marcados principalmente pela perspectiva militar (SANT'ANNA, 2004). Entretanto essa história pode ser contada a partir da análise de documentos oficiais e demais materiais que os sustentam como: artigos, fotografias etc. Além disso, tem uma obra reconhecida e lida por profissionais e estudantes da área, a qual foi escrita por Lino Castellani Filho em uma perspectiva distinta das demais, pois não realiza aproximação com a história da Educação Física e as instituições militares, tanto é que foi titulada: "Educação Física no Brasil: a história que não se conta", cuja primeira edição foi publicada em 1998.

Conta-se que tudo começou com os primeiros grupos de colonos, imigrantes e militares, que se instalaram em distintas partes do Brasil e construíram o projeto de Educação Física no país, fundamentados na execução de atividades com o intuito de lazer, formação corporal ou disciplina. Entre o período de 1824 a 1931, o exercício físico foi o marco, a partir da preparação física, defesa pessoal, o jogo e esportes no ambiente militar (SOUZA NETO et al., 2004).

Castellani Filho (2001) retrata que esse início de história esteve pautado na filosofia positivista e não foi marcada apenas pelos militares, mas sim pelos médicos, levando associar à Educação do Físico, à Saúde Corporal, norteados pela medicina social do tipo higiênica. Os discursos apresentados, de cunho médico, levaram à Educação Física higienista, compreendendo-a como sinônimo de saúde física e mental, a fim de promover a saúde, regeneração da raça, das virtudes e da moral (DARIDO; SANCHES NETO, 2005; SOARES, 2012).

Influenciados por essa perspectiva higienista, os educadores começaram a defender a ideia de incluir a prática de ginástica nos colégios. Também se conta que Educação Física, no ambiente escolar, fez-se presente oficialmente, em 1851, com a reforma Couto Ferraz, 
entretanto foi em 1882, no estado do Rio de Janeiro, com a reforma proposta por Rui Barbosa, que apareceram recomendações sobre a obrigatoriedade da prática da ginástica para ambos os sexos. Essa reforma, contudo, foi reconhecida em distintos estados a partir de 1920 (DARIDO; SANCHES NETO, 2005).

Em virtude disso, surgem discussões sobre a dicotomia da formação em Educação Física, como por exemplo, no estudo de Cruz (2011) que aborda sobre a formação humana a partir de análise documental de teses, periódicos e dissertações.

\begin{abstract}
Ao analisarmos a produção sobre a formação de professores em teses, periódicos e dissertações, observamos a existência de argumentos que identificam a Licenciatura vinculada ao processo de formação humana, enquanto o Bacharelado é identificado com a formação profissional. Entretanto, nos cabe alertar que ambos são projetos de formação humana e da forma como estão configurados, são complementares no modo hegemônico de produção da vida, haja vista a questão dos campos de atuação profissional da Licenciatura (espaços formais) e do Bacharelado (espaços não formais) (CRUZ, 2011, p. 36).
\end{abstract}

Logo, conforme a organização dos currículos norteados pela legislação vigente, a Licenciatura está centrada na formação de profissionais em ambientes formais com preocupações de cunho pedagógico. Em contrapartida, o curso de Graduação (Bacharelado) busca formar profissionais para atuação em contextos não formais nos aspectos técnicos e científicos. No entanto Cruz (2011) defende a ideia de que essa perspectiva de distinção, a atuação profissional desconsidera a docência no ambiente não formal, elencando ainda que os contextos formais ou não formais necessitam desenvolver a dimensão pedagógica, técnica, científica, política, ética e moral. Ainda nessa visão dicotômica quanto à formação de profissionais de Educação Física, Nunes (2016) aponta que as discussões sobre as formações de Licenciatura ou Bacharelado questionam os respectivos vieses, e se estão buscando uma sociedade democrática em todos os segmentos ou apenas na lógica competitiva do mercado de trabalho.

A partir das metas estipuladas no Plano Nacional de Educação - PNE - de 2014 e análise da trajetória das DCNs em Educação Física constitui-se o Parecer 584/2018 de 03 de outubro de 2018, referente à integração do Bacharelado e da Licenciatura em Educação Física para IES de caráter público e privado, as quais terão um prazo de até dois anos para a reestruturação. Entretanto o Bacharelado terá como ponto norteador nos aspectos teóricos e metodológicos o Sistema Único de Saúde (SUS), e a Licenciatura estará associada à Formação de Professores e Educação Escolar. Também apresentaram a incorporação de inovações científicas, tecnológicas e pedagógicas no processo de ensino-aprendizagem, 
apontando a necessidade da consolidação em algumas ações nos Projetos Políticos Pedagógicos do curso em Educação Física (BRASIL, 2018a):

[...] 1) metodologias ativas de ensino-aprendizagem; 2) estruturas curriculares que integrem conhecimentos da formação geral e da formação específica, bem como a articulação da teoria com a prática; 3) vivências continuadas em cenários de práticas diversificadas; e 4) planejamento curricular, que considere as prioridades e as necessidades dos indivíduos, famílias e comunidades, e os contextos em que os cursos se inserem (BRASIL 2018a, p. 02).

Os pesquisadores da área de currículo, formação e desenvolvimento profissional vêm se preocupando em compreender todas as nuances do processo de formação de profissionais de Educação Física. Assim surgem artigos e livros discutindo temas que permitem aproximações e entendimento como um todo. Destaca-se a obra de Nascimento e Farias (2012), que aborda a construção da identidade profissional em Educação Física: da formação à intervenção. O livro faz parte de uma coletânea intitulada: temas em movimento, elaborada por diferentes pesquisadores da área, atuantes no âmbito nacional e internacional. A obra é dividida em seis partes:

I. a construção da identidade em Educação Física - aborda o desenvolvimento profissional do professor de Educação Física nos aspectos da sua aprendizagem e processo de decisões; nova abordagem na formação de treinadores; a construção profissional de professores de Educação Física; (re)configuração da identidade profissional no estágio profissional; estágio profissional de professores de Educação Física.

II. desafios dos estágios na formação em Educação Física - discute sobre as representações dos professores de Educação Física na prática supervisionada; proposições do estágio disciplinar na formação de professores; relatos sobre o estágio na escola; descrições e desafios sobre o estágio curricular nos cursos de Bacharelado.

III. desafios das práticas pedagógicas na formação inicial em Educação Física - trata da prática pedagógica como componente curricular; e da extensão na formação inicial.

IV. conhecimentos para formação e intervenção profissional em Educação Física explora os desafios da docência universitária; formação inicial e a legislação; inquietações sobre a formação e intervenção na área; a prática pedagógica como referência.

V. formação inicial e a intervenção profissional em Educação Física - articula sobre a atuação e os desafios na área do esporte, da escola, da saúde e da gestão. Ainda mais inovação da Educação Física na formação de profissionais deficientes. 
VI. redes de pesquisa e associações de ensino em Educação Física - discorre sobre os contextos e proposições das investigações na formação em Educação Física a partir da Rede Ibero-americana e os passos e comentários iniciais das associações de ensino e formação do bacharel em Educação Física.

À luz da organização dessa única obra de Nascimento e Farias (2012) é possível perceber a grandeza das discussões que contornam a formação inicial em Educação Física no século XXI. Ao olhar o percurso histórico, a Educação Física vem ganhando espaço na sociedade, isso é visível a partir do crescimento na oferta dos cursos no país. Tal perspectiva se evidencia a partir de estudos como do Instituto Nacional de Estudos e Pesquisas Educacionais Anísio Teixeira - INEP (HUNGER et al., 2006) sobre a trajetória dos cursos da graduação na saúde, período de 1991 a 2004, o qual pôde identificar a existência de 117 cursos no país no ano de 1991, enquanto em 2004 aumentou para 469. Ao final da análise, Hunger et al. (2006) entenderam que houve um crescimento desordenado na oferta de cursos e vagas em diferentes regiões do país, principalmente pela alta demanda de cursos presenciais nas regiões sul e sudeste do país. Ainda aponta:

Embora a Educação Física seja uma das áreas da saúde com maior número de cursos de formação inicial, há necessidade de implementação de um plano estratégico a fim de garantir a sua oferta em todas as unidades da federação, além de minimizar as desigualdades regionais [...] (HUNGER et al., 2006, p. 137).

No estudo de Collet et al. (2009), que aborda a trajetória dos cursos de Educação Física de 2000-2006, identificou que: no ano de 2006, o país tinha 746 cursos presenciais, sendo 274 em IES pública e 472 em IES privada. Os autores ainda revelaram, dessa totalidade 512 foram do curso com formação em Licenciatura e 234 em Bacharelado. Corrêa et al. (2016) buscaram em sua investigação realizar levantamento histórico dos cursos de formação inicial em Educação Física (presenciais) no Brasil, séculos XX e XXI, e traçar o perfil de crescimento nesse período. A partir disso elaboraram um gráfico (Figura 3), representando a quantidade de cursos de Educação Física (Licenciatura e Bacharelado), para tanto utilizaram como faixa de corte o quinquênio. 
Figura 3 - Distribuição dos cursos de Formação Inicial em Educação Física de 1935 a 2013

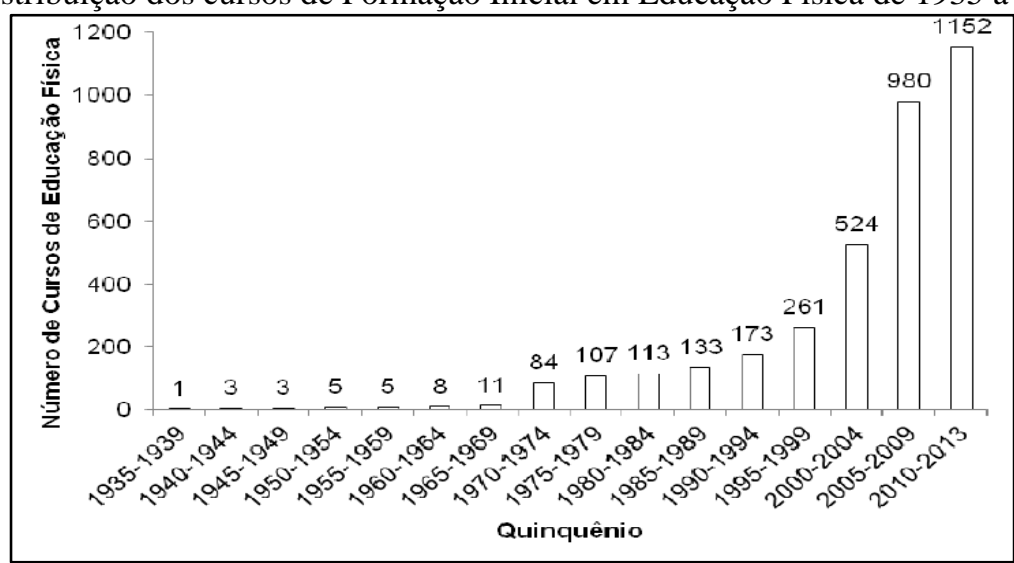

Fonte: Corrêa et al. (2016, p. 30)

Os autores ainda apontam as especificidades dos números encontrados nos cursos de Licenciatura e Bacharelado, IES pública ou privada, bem como o aumento relativo e absoluto conforme o período anterior analisado. Destacaram, porém, que no período 2010-2013 foram identificados 703 cursos de Licenciatura ( $n=170$ IES pública e n=533 IES privada) e 449 cursos de Bacharelado ( $\mathrm{n}=81$ IES pública e n=368 IES privada).

Observamos que os estudos de Collet et al. (2009) e Corrêa et al. (2016) estão centrados nos cursos presenciais. Em virtude disso viu-se a necessidade de apresentar um panorama entre 2007-2017 dos cursos presenciais e a distância em Educação Física (Tabela 7), considerando o crescimento da Educação a Distância - EaD e a oferta acelerada de cursos nos últimos tempos em diversas áreas.

Tabela 7 - Desenvolvimento em número dos cursos de Educação Física presencial e a distância de 2007-2017

\begin{tabular}{ccccccccccccc}
\hline Ano & \multicolumn{3}{c}{$\begin{array}{c}\text { Licenciatura a } \\
\text { Distância }\end{array}$} & \multicolumn{3}{c}{$\begin{array}{c}\text { Bacharelado a } \\
\text { Distancia }\end{array}$} & \multicolumn{3}{c}{$\begin{array}{c}\text { Licenciatura } \\
\text { Presencial }\end{array}$} & \multicolumn{3}{c}{$\begin{array}{c}\text { Bacharelado } \\
\text { Presencial }\end{array}$} \\
\hline & Púb. & Priv. & Total & Púb. & Priv. & Total & Púb. & Priv. & Total & Púb. & Priv. & Total \\
\hline 2007 & 1 & 3 & 4 & 0 & 0 & 0 & 127 & 280 & 407 & 52 & 228 & 280 \\
\hline 2008 & 1 & 3 & 4 & 16 & 0 & 16 & $129 \uparrow$ & $296 \uparrow$ & $425 \uparrow$ & $71 \uparrow$ & $264 \uparrow$ & $335 \uparrow$ \\
\hline 2009 & $2 \uparrow$ & $4 \uparrow$ & 6 & 16 & 0 & 16 & $115 \downarrow$ & $307 \uparrow$ & $422 \downarrow$ & $94 \uparrow$ & $287 \uparrow$ & $381 v$ \\
\hline 2010 & $21 \uparrow$ & 4 & 25 & $0 \downarrow$ & 0 & $0 \downarrow$ & $173 \uparrow$ & $446 \uparrow$ & $619 \uparrow$ & $77 \downarrow$ & $274 \downarrow$ & $351 \downarrow$ \\
\hline 2011 & $24 \uparrow$ & 4 & 28 & 0 & 0 & 0 & $181 \uparrow$ & $454 \uparrow$ & $635 \uparrow$ & $88 \uparrow$ & $307 \uparrow$ & $395 \uparrow$ \\
\hline 2012 & $27 \uparrow$ & 4 & 31 & 0 & $1 \uparrow$ & $1 \uparrow$ & $197 \uparrow$ & $451 \downarrow$ & $648 \uparrow$ & $103 \uparrow$ & $316 \uparrow$ & $419 \uparrow$ \\
\hline 2013 & $12 \downarrow$ & $3 \downarrow$ & $15 \downarrow$ & 0 & 1 & 1 & $180 \downarrow$ & $450 \downarrow$ & $630 \downarrow$ & $100 \uparrow$ & $332 \uparrow$ & $432 \uparrow$ \\
\hline 2014 & 12 & $5 \uparrow$ & 17 & 0 & 1 & 1 & $200 \uparrow$ & $454 \uparrow$ & $654 \uparrow$ & $98 \downarrow$ & $355 \uparrow$ & $453 \uparrow$ \\
\hline 2015 & 12 & $7 \uparrow$ & 19 & 0 & 1 & 1 & $194 \downarrow$ & $467 \uparrow$ & $661 \uparrow$ & $86 \downarrow$ & $392 \uparrow$ & $478 \uparrow$ \\
\hline 2016 & $13 \uparrow$ & $14 \uparrow$ & 27 & 0 & $7 \uparrow$ & $7 \uparrow$ & $181 \downarrow$ & $474 \uparrow$ & $655 \downarrow$ & $88 \uparrow$ & $440 \uparrow$ & $528 \uparrow$ \\
\hline 2017 & 13 & $17 \uparrow$ & 30 & 0 & $13 \uparrow$ & $13 \uparrow$ & $168 \downarrow$ & $498 \uparrow$ & $667 \uparrow$ & $89 \uparrow$ & $510 \uparrow$ & $599 \uparrow$ \\
\hline
\end{tabular}

Fonte: Adaptado do INEP (2008; 2009; 2010; 2011; 2012; 2013; 2014; 2015; 2016; 2017; 2018)

*Púb - Pública

*Priv - Privada

$\uparrow$ Aumentou comparado ao ano anterior

$\downarrow$ Baixou comparado ao ano anterior 
Os cursos de Licenciatura em Educação Física a distância, apresentaram um desenvolvimento crescente de 2007-2012, considerando a maior incidência de 2010-2012, cujo ápice de cursos foi alcançado no ano de 2012. Esse movimento converge com as perspectivas apresentadas no PNPG de 2001-2010, o qual apontou a EaD como ferramenta auxiliadora para o desenvolvimento da universalização e democratização do Ensino no Brasil. Além disso, o PNPG a considerou subsídio importante para formação e capacitação de professores em serviço e também julgou o projeto de universidade aberta como ferramenta de formação de profissionais qualificados (BRASIL, 2001b).

A partir dos objetivos e metas estabelecidas nesse plano nacional, como por exemplo: “estabelecer um amplo sistema interativo de educação a distância, utilizando-o, inclusive, para ampliar as possibilidades de atendimento nos cursos presenciais, regulares ou de educação continuada (BRASIL, 2001b, p. 35)", percebemos um movimento de interesse e investimento para EaD. Assim surge o Decreto 5.800 de 8 de junho de 2006, que dispõe sobre o Sistema Universidade Aberta do Brasil - UAB, apresentando os seguintes objetivos:

I - oferecer, prioritariamente, cursos de Licenciatura e de formação inicial e continuada de professores da educação básica; II - oferecer cursos superiores para capacitação de dirigentes, gestores e trabalhadores em educação básica dos Estados, do Distrito Federal e dos Municípios; III - oferecer cursos superiores nas diferentes áreas do conhecimento; IV - ampliar o acesso à educação superior pública; V - reduzir as desigualdades de oferta de ensino superior entre as diferentes regiões do País; VI - estabelecer amplo sistema nacional de educação superior a distância; e VII - fomentar o desenvolvimento institucional para a modalidade de educação a distância, bem como a pesquisa em metodologias inovadoras de ensino superior apoiadas em tecnologias de informação e comunicação (BRASIL, 2006, p.1).

Dessa forma, compreendemos que o processo de desenvolvimento da $\mathrm{EaD}$ na área da Educação Física está imbricado no surgimento do PNPG, principalmente no Decreto 5.800/2006. Assim justifica-se o maior número de cursos de Licenciatura, visto que o objetivo está centrado, prioritariamente, na formação de professores.

Enquanto o curso de Bacharelado em Educação Física em EaD apresentou a maior demanda ( $\mathrm{n}=16)$ no período 2008 e 2009 na Universidade Federal do Amazonas - UFAM, a qual disponibilizou o curso em diversos campi, mas encerrou o acesso de ingresso em 2010. Tal ação corroborou com o objetivo cinco da $U A B$, que visa à redução da desigualdade de oferta no ensino superior em diferentes regiões do país.

No entanto, a partir de 2013, no curso de Licenciatura em EaD, houve uma diminuição de $\pm 50 \%$ no ano anterior, essa oscilação deu-se, principalmente, porque a oferta nas instituições públicas passou de 27 para 12 cursos, assim permanecendo até 2015, quando 
surgiu apenas mais uma em 2016-2017. Já o curso de Bacharelado não apresenta nenhum curso em IES pública até a data do levantamento dos dados em discussão - 2007-2017.

O número total de instituições privadas até 2015 atinge $\pm 50 \%$ do número total das públicas, mas em 2016 esse cenário mudou e as IES privadas superaram a oferta das IES públicas com um curso a mais em EaD para formação de professores de Educação Física e com o ápice em 2017 (n=17). Quanto ao curso de Bacharelado, a partir de 2012 a oferta esteve centrada nas instituições privadas, apresentando o maior número em 2017 com 13 cursos.

Nos cursos presenciais, as instituições privadas ao longo do período analisado, 20072017, tiveram mais ofertas em detrimento das públicas, apresentando-se sempre num crescente. Tal prevalência continuou mesmo com o PNPG de 2010-2020 visando fomentar a oferta à Educação Superior pública e gratuita, principalmente na formação de professores para Educação Básica (BRASIL, 2010). Em contrapartida, ao analisarmos os dados da tabela 7, percebemos que a realidade do surgimento de cursos de Educação Física no Ensino Superior em instituições públicas diminuiu nos anos de 2013, 2015, 2016 e 2017 para o curso de Licenciatura, e em 2010, 2014 e 2015 nos cursos de Bacharelado. O aumento que ocorreu nos cursos de Bacharelado foi considerado baixo nos períodos de 2015-2016 (n=2) e 2016$2017(n=1)$.

O PNPG de 2010-2020 apontou o interesse em expandir o financiamento estudantil por meio do Fundo de Financiamento ao Estudante Ensino Superior - FIES dispensando o fiador. Estratégias como essa pode ter incentivado o surgimento de cursos ou até mesmo reabertura de cursos nas IES privadas, principalmente os presenciais, os quais obtiveram apenas duas baixas, uma em 2010, no curso de Bacharelado, e no curso de Licenciatura, em Há aqueles que descrevem que o modelo adotado nas escolas foi de cunho obrigatório, à luz de formar gerações capazes de suportar o combate, a luta, para atuar na guerra, favorecendo os fortes e excluindo aqueles incapacitados (DARIDO; SANCHES NETO, 2005). Enquanto Castellani Filho (2001) não nega a presença dessas características, ainda mais, o Projeto de Rui Barbosa compartilhava de ideias semelhantes, mas ainda aponta sobre a participação da mulher nas aulas de ginástica. Tal ideia vinha de Fernando Azevedo, ao defender que, a partir da Educação Física, a mulher ficaria mais sadia e forte para gerar filhos saudáveis para a sociedade. Em virtude desse cenário, houve contrariedade de muitos, como da igreja católica, conforme apontado também no trecho do livro de Castellani Filho (2001, p.52) sobre os dizeres de um católico: 
[...] dizer que inimiga desta educação física e dos esportes, a Igreja Católica é, ignorado ou mal compreendendo a sua doutrina, desconhecer ainda o desnaturar completamente a sua história. Não aplaude, de certo, os exercícios físicos quando esses visam, apenas formar um belo bruto, orgulho ao contemplar os seus músculos peitorais ou seus bíceps. Com esse carácter, entretanto, tais exercícios não são educativos, pois cultuam o corpo como finalidade, quando ele é um meio ou instrumento a serviço da alma [...]

Apesar desse cenário divergente, a formação em Educação Física apresentou origem militar, a partir de uma missão francesa (1909), a fim de ministrar instrução militar à força policial do estado de São Paulo, assim resultando na formação dos primeiros mestres de ginástica e esgrima (HUNGER et al., 2006). Castellani Filho (2001) aponta também a presença significativa dessa missão para o surgimento da Escola de Educação Física da Força Policial do Estado de São Paulo, no entanto descreve que ocorreu em 1907. Até 1929 os cursos eram prioritariamente aos militares, mas nesse ano foi realizado um curso provisório de Educação Física, a fim de integrar os civis.

Em 1933 deixou de se tornar formação exclusiva por militares a partir do Decreto 23.232, assim surgindo a Escola de Educação Física do Exército (EsEFEx), na cidade do Rio de Janeiro, possibilitando a formação de oficiais e sargentos, bem como de monitores civis (SOUZA NETO et al., 2004; HUNGER et al., 2006). Logo em seguida, também surge o programa civil em Educação Física pela Escola de Educação Física do Estado de São Paulo, iniciando seu funcionamento em 1934. O curso apresentava formação profissional na perspectiva do instrutor de ginástica e professor de Educação Física, visando ao estudo: da vida humana em seus aspectos celulares, anatômicos, funcional, mecânico e preventivo; do exercício físico da infância à idade madura; dos exercícios motores e agonísticos; dos processos pedagógicos e desenvolvimento do aluno; dos exercícios motores artísticos; de fatores e costumes relacionados às tradições dos povos da área dos exercícios físicos e motores (SOUZA NETO et al., 2004). Nessa fase percebemos que a Educação Física inicia o desligamento com as concepções militares, entrando no novo ciclo formativo (CORRÊA et al., 2016).

Conta-se que a obrigatoriedade da Educação Física no sistema escolar apareceu pela primeira vez na Reforma Francisco Campos (1931), ocorrendo efetivamente na Constituição dos Estados Unidos do Brasil em 1937, nos artigos 131 e 132 (CASTELLANI FILHO, 2001). Tal exigência sobre a Educação Física na escola, possibilitou o aprimoramento da proposta de 1934, desenvolvendo-a, em 1939, à luz da formação de instrutores de ginástica (professoras primárias); instrutor de ginástica; professor de Educação Física; médico especializado em Educação Física; técnico em massagem e técnico desportivo. Todavia 
modifica-se o estudo no aspecto pedagógico (psicologia aplicada); e acrescenta administração do trabalho humano em instituições (organização e legislação) (SOUZA NETO et al., 2004). O autor ainda revela:

\begin{abstract}
Essa conquista deu-se em 1939, por meio do decreto-lei n. 1.212 que criou a Escola Nacional de Educação Física e Desportos [ENEFD na Universidade do Brasil no Rio de Janeiro] e estabeleceu as diretrizes para a formação profissional. Entretanto, para além do discurso de determinado grupo, tem início um processo de organização e regulamentação que irá contribuir para a constituição do campo da Educação Física, pois se organizou e se regulamentou a profissão entre leigos e não-leigos na constituição do seu "campo" (SOUZA NETO et al., 2004, p.116).
\end{abstract}

O estudo de Corrêa et al. (2016) parte do pressuposto que esses dois cursos criados em 1934 e 1939 coincidem com a criação do Novo Estado e promulgação da Carta Magna. O governo apresenta como estratégia o desenvolvimento da educação profissionalizante para as classes sociais baixas, advinda da Reforma Francisco Campo, de 1931. A Educação Física continuou promovendo suas modificações e aprimoramento conforme as necessidades apresentadas, além do espaço e conhecimento adquiridos junto à sociedade.

Assim, a Educação Física militarista começou a ceder espaço para uma concepção pedagogicista. Isso foi iniciado pela criação do decreto-lei n.8.270 de 1945, ao apontar a organização dos cursos que seriam ministrados pela Escola Nacional de Educação Física, o tempo do curso, as disciplinas conforme cada ano, exigência ao se matricular e denominação do diploma a ser adquirido. Alguns pontos foram semelhantes ao Decreto-lei $\mathrm{n}^{\mathrm{o}} 1.212$, de 17 de abril de 1939 , mas mudando a redação dos artigos. $2^{\circ}, 3^{\circ}, 4^{\circ}, 5^{\circ}, 6^{\circ}, 7^{\circ}, 9^{\circ}, 12,21$ e $26 . \mathrm{O}$ quadro 4 apresenta a comparação entre esses dois decretos-lei, como a terminologia dos cursos foi alterada, o tempo de duração do Superior em Educação Física de dois passou para três anos e exigências para ingressar. Além dessas alterações, também foi possível verificar a reorganização das disciplinas e correspondente carga horária.

Quadro 4 - Comparação dos cursos ministrados pela Escola Nacional de Educação Física e Desportos conforme os decretos-lei $\mathrm{n}^{\circ} 1.212 / 39$ e $8.270 / 45$

\begin{tabular}{|c|c|c|c|c|c|}
\hline \multicolumn{2}{|c|}{ CURSOS } & \multicolumn{2}{|c|}{ DURAÇÃO } & \multicolumn{2}{|c|}{ EXIGÊNCIA PARA INGRESSAR } \\
\hline 1939 & 1945 & 1939 & 1945 & 1939 & 1945 \\
\hline $\begin{array}{l}\text { Superior de } \\
\text { Educação } \\
\text { Física }\end{array}$ & $\begin{array}{c}\text { Superior de } \\
\text { Educação } \\
\text { Física }\end{array}$ & 2 anos & 3 anos & $\begin{array}{l}\text { Certificado de } \\
\text { conclusão do } \\
\text { curso secundário } \\
\text { fundamental }\end{array}$ & $\begin{array}{l}\text { Certificado de } \\
\text { licença ginasial }\end{array}$ \\
\hline
\end{tabular}




\begin{tabular}{|c|c|c|c|c|c|}
\hline $\begin{array}{c}\text { Normal de } \\
\text { Educação } \\
\text { Física }\end{array}$ & $\begin{array}{c}\text { Educação física } \\
\text { infantil }\end{array}$ & 1 ano & 1 ano & $\begin{array}{c}\text { Diploma de } \\
\text { normalista }\end{array}$ & $\begin{array}{c}\text { Diploma de } \\
\text { normalista }\end{array}$ \\
\hline $\begin{array}{c}\text { Técnica } \\
\text { desportiva }\end{array}$ & $\begin{array}{c}\text { Técnica } \\
\text { desportiva }\end{array}$ & 1 ano & 1 ano & $\begin{array}{l}\text { Certificado de } \\
\text { conclusão do } \\
\text { curso secundário } \\
\text { fundamental }\end{array}$ & $\begin{array}{c}\text { Diploma de } \\
\text { licenciado em } \\
\text { Educação Física }\end{array}$ \\
\hline $\begin{array}{c}\text { Treinamento e } \\
\text { massagem }\end{array}$ & Massagem & 1 ano & 1 ano & $\begin{array}{l}\text { Certificado de } \\
\text { conclusão do } \\
\text { curso secundário } \\
\text { fundamental }\end{array}$ & $\begin{array}{l}\text { Certificado de } \\
\text { licença ginasial }\end{array}$ \\
\hline $\begin{array}{l}\text { Medicina da } \\
\text { Educação } \\
\text { Física e dos } \\
\text { desportos }\end{array}$ & $\begin{array}{c}\text { Medicina } \\
\text { aplicada à } \\
\text { Educação } \\
\text { Física e aos } \\
\text { desportos }\end{array}$ & 1 ano & 1 ano & $\begin{array}{l}\text { Diploma de } \\
\text { médico }\end{array}$ & $\begin{array}{l}\text { Diploma de } \\
\text { médico, } \\
\text { devidamente } \\
\text { registrado }\end{array}$ \\
\hline
\end{tabular}

Fonte: Adaptação Brasil (1939) e Brasil (1945)

Tornou-se mais evidente essa perspectiva pedagógica com o surgimento da LDB n. 4024, no ano de 1961, ao abordar um capítulo (cap. IV) sobre a formação do magistério para o Ensino Primário e Médio. Dessa forma, a Educação Física iniciou as discussões frente ao modelo bio-sócio-psico-filosófico (GONÇALVES, 2006), conduzida pelo art. 63:

Nas faculdades de filosofia será criado, para a formação de orientadores de educação do ensino médio, curso especial a que terão acesso os licenciados em pedagogia, filosofia, psicologia ou ciências sociais, bem como os diplomados em Educação Física pelas Escolas Superiores de Educação Física e os inspetores federais de ensino, todos com estágio mínimo de três anos no magistério (BRASIL, 1961 , s.p).

Em seguida o país sofre um golpe militar (31 de março e $1^{\circ}$ de abril de 1964), impedindo a participação da população na vida política (GONÇALVES, 2006). O país investiu na prática esportiva de alto rendimento, buscando a seleção do mais forte. A prática era caracterizada pelo mecanismo dos movimentos esportivos e o professor tinha papel centralizador. Dessa forma, também se chamou de modelo esportivista, mecanicista e 
tecnicista, ainda enraizado na prática da Educação Física escolar (DARIDO; SANCHES NETO, 2005).

Nesse período de 1939-1969 não houve um surgimento significativo de cursos de formação em Educação Física, totalizando 11 cursos existentes (1969). Mas a criação de cursos foi aumentando a partir da Lei 5.540/68, o que proporcionou a reforma universitária com a departamentalização, o sistema de créditos, pós-graduação e carreira docente (CORRÊA et al., 2016).

Ainda, o art. 70 aponta que o Conselho Federal de Educação - CFE - fixará o currículo mínimo e a duração dos cursos que habilitem à obtenção de diploma (BRASIL, 1961). De acordo com isso o CFE, a partir do Parecer 672/62 de 4 de setembro de 1969, o qual norteou a Resolução 9/69 de 10 de outubro de 1969, estabelece as disciplinas pedagógicas fixas da Licenciatura (Psicologia da Educação; Didática; Estrutura e Funcionamento do Ensino do $2^{\circ} \mathrm{Grau}$ ), bem como a formação pedagógica em 1/8 de horas obrigatórias de trabalho (BRASIL, 2001c).

Além disso, a Educação Física apresentou mudanças na formação de profissionais, a partir da Resolução de CFE 69/69, reestruturando o curso de Licenciatura e Técnico Desportivo, com o mínimo de carga horária de 1.800 horas e respaldado na concepção biológica e atenção no "saber-fazer" (SOUZA NETO et al., 2004; BENITES; SOUZA NETO; HUNGER, 2008). "Os saberes relativos ao conhecimento esportivo ganham destaque bem como a parte didática com ênfase mais específica voltada para a formação do professor" (SOUZA NETO et al., 2004, p. 119).

Foi a partir da reforma do Ensino Superior, por meio do Decreto $n^{\circ} 69.450$, de $1^{\circ}$ de novembro de 1971, que a Educação Física ganhou espaço para atuação no nível superior, com predominância das práticas desportivas. Tal perspectiva objetivou favorecer a manutenção e o aprimoramento da aptidão física à conservação da saúde, à integração dos estudantes no campus universitário e à consolidação do sentimento comunitário e de nacionalidade (GONÇALVES, 2006). Isso se revela no art. 2: "a Educação Física, desportiva e recreativa integrará, como atividade escolar regular, o currículo dos cursos de todos os graus de qualquer sistema de ensina" (BRASIL, 1971, s.p).

Esse momento histórico marcou a criação dos cursos de Educação Física, passando de 11 (1960-1969) para 84 (1970-1975) e 107 (1975-1979) (CORRÊA et al., 2016). Segundo esse autor, está associado a dois pontos: a) criação de cursos de Licenciatura em Educação Física em IES privadas; b) ao incentivo à prática esportiva no ambiente escolar como formação de atletas, a fim de representar o país em eventos internacionais. Nesse período 
também percebemos o aumento no número de academias, na área da ginástica e a implementação de escolinhas esportivas (BENITES; SOUZA NETO; HUNGER, 2008).

Foi em 1987, todavia, o marco histórico da Educação Física, a partir do surgimento da Resolução 03/CFE/87, a qual declara a divisão do curso de Licenciatura e Bacharelado, diferenciando o espaço de atuação profissional. O curso de Licenciatura objetivava formar professores para a Educação Básica e o curso de Bacharelado habilitava para intervenção profissional em espaços fora do meio educacional, buscando a inserção no espaço da saúde (SOUZA NETO et al., 2004; BENITES; SOUZA NETO; HUNGER, 2008). Conforme o art. $2^{\circ}$ dessa resolução, o objetivo dos currículos, elaborados pelas IES era:

\begin{abstract}
possibilitar a aquisição integrada de conhecimentos e técnicas que permitam uma atuação nos campos da Educação Escolar (pré-escolar, $1^{\circ}, 2^{\circ}$ e $3^{\circ}$ graus) e NãoEscolar (academias, clubes, centros comunitários, condomínios etc.); - desenvolver atitudes éticas, reflexivas, críticas, inovadoras e democráticas; prover o aprofundamento das áreas de conhecimentos, de interesse e de aptidão do aluno, estimulando-o ao aperfeiçoamento contínuo; - propiciar a auto-realização do estudante, como pessoa e como profissional (BRASIL, 1987, s.p).
\end{abstract}

Os currículos dos cursos foram divididos em duas partes: formação geral (humanística - conhecimento filosófico; conhecimento do Ser Humano; conhecimento da sociedade - e técnica - conhecimento técnico - articulando com os demais conhecimentos) e aprofundamento de conhecimentos. Então ficou a critério de cada IES elaborar as disciplinas conforme esses dois norteamentos. Importante salientar que a primeira parte da formação precisava respeitar as peculiaridades de cada região e o perfil de profissional almejado; e a segunda parte da formação determina o desenvolvimento de forma teórico-prática, aproximando as experiências reais da profissão (BRASIL, 1987).

Prosseguindo, em 1989, surge o primeiro curso de doutorado, assim efetivando uma nova fase da Educação Física no país (TANI, 2016). O autor ainda aponta que a estruturação da base acadêmico-científica da Educação Física no Brasil surgiu a partir da implementação da pós-graduação.

Ao longo dos anos 90, surgem algumas mudanças na legislação brasileira, as quais refletem positivamente na área da Educação Física, como: a nova LDB de 1996 (Lei n ${ }^{\circ}$ 9.394/96) ao apontar no inciso $3^{\circ}$ do art.26 a obrigatoriedade no currículo de Educação Básica, bem como sua integralidade na proposta pedagógica da escola. Na perspectiva de Hunger et al. (2006), essa normativa também contribuiu no sistema de ensino superior, apresentando uma reorganização acadêmica (universidade, centros universitários, faculdades integradas, faculdades, escolas e instituições); e os cursos de Licenciatura tornaram-se cursos 
específicos para formação de professores da Educação Básica e as dimensões práticas passaram a permear todo o currículo.

Além disso, em 1997, a Resolução nº 218 do Conselho Nacional de Saúde - CNS reconhece o profissional de Educação Física na área da saúde (BRASIL, 1997). Dessa forma, ganhamos mais reconhecimento e espaço na sociedade, bem como é possível identificar a importância da prática de exercício físico em benefício à saúde, como fator preventivo. Por fim, fecha-se esse período com a Lei 9.696/1998 que regulamenta a Profissão de Educação Física, a qual legitima no art. $1^{\mathrm{o}}$ : “o exercício das atividades de Educação Física e a designação de Profissional de Educação Física é prerrogativa dos profissionais regularmente registrados nos Conselhos Regionais de Educação Física” (BRASIL, 1998, s.p). O art. 3º ao apontar sobre o que compete a esse profissional, já faz menção sobre a participação em equipes multidisciplinares e interdisciplinares associadas ao reconhecimento na área da saúde.

\footnotetext{
Art. 3o- Compete ao Profissional de Educação Física coordenar, planejar, programar, supervisionar, dinamizar, dirigir, organizar, avaliar e executar trabalhos, programas, planos e projetos, bem como prestar serviços de auditoria, consultoria e assessoria, realizar treinamentos especializados, participar de equipes multidisciplinares e interdisciplinares e elaborar informes técnicos, científicos e pedagógicos, todos nas áreas de atividades físicas e do desporto (BRASIL, 1998, s.p)
}

Independentemente das mudanças decorrentes do final da década de 90, na área da Educação Física, o Ministério da Educação, em 2001, iniciou algumas modificações referentes aos cursos de Licenciatura, pois identificam que estavam tornando-se anexos aos cursos de Bacharelado, consequentemente interferindo na construção da identidade teórica, epistemológica e profissional dos professores. Entretanto tais mudanças também contribuíram para a formação de profissionais de Educação Física, pois a Resolução 1, de 18 de fevereiro de 2002 descreve as diretrizes para a formação do professor da Educação Básica.

Essa resolução permitiu identificar que os currículos dos cursos de Licenciatura deixaram de obter ênfase nos conteúdos específicos da disciplina (tal situação ocorria fortemente no curso de Educação Física). Então foram apresentadas competências específicas, no art. $6^{\circ}$, as quais visam ao papel da escola na sociedade e à prática pedagógica da Educação Infantil até o Ensino Médio.

Art. $6^{\circ}[\ldots]$ I - as competências referentes ao comprometimento com os valores inspiradores da sociedade democrática; II - as competências referentes à compreensão do papel social da escola; III - as competências referentes ao domínio 
dos conteúdos a serem socializados, aos seus significados em diferentes contextos e sua articulação interdisciplinar; IV - as competências referentes ao domínio do conhecimento pedagógico; $\mathrm{V}$ - as competências referentes ao conhecimento de processos de investigação que possibilitem o aperfeiçoamento da prática pedagógica; VI - as competências referentes ao gerenciamento do próprio desenvolvimento profissional (BRASIL, 2002, p.02).

Em seguida surge a Resolução 7/2004 - Diretrizes Curriculares Nacionais dos Cursos de Educação Física (DCNs em Educação Física) descrevendo as orientações específicas de cada curso - Graduação em Educação Física (Bacharelado) e o de Licenciatura em Educação Física, além disso permitiu delinear o perfil do profissional para as duas formações (BRASIL, 2004). Atualmente, houve modificações no currículo e na organização dos cursos conforme a legislação vigente, o Curso de Bacharelado corresponde às especificidades da Resolução CNE/CES n ${ }^{\circ} 4$ de 6 de abril de 2009, enquanto o Curso de Licenciatura é norteado pela Resolução CNE/CP n ${ }^{\circ} 2$ de $1^{\circ}$ de julho de 2015.

Não obstante as discussões sobre a organização dessa formação não cessaram nos eventos regionais, nacionais e internacionais, na comunidade acadêmica, nas conversas entre profissionais, muito menos no Conselho Federal de Educação Física - CONFEF. Este estudo, entretanto, não pretende julgar a coesão dessas formações, mas sim descrever os pontos existentes na literatura atual e a legislação que a norteia, e realizar uma reflexão sobre os possíveis impactos na formação do docente de Educação Física atuante no Ensino Superior.

Dessa forma, compreende a formação inicial como o início da formação profissional, concretizada pelo nível de graduação e/ou magistério (FARIAS; SHIGUNOV; NASCIMENTO, 2001). Na Educação Física busca formar profissionais para atuar em distintos seguimentos na educação, saúde, lazer, esporte, dentre outros, conforme especificado no o art. $3^{\circ}$ da Resolução 07/2004.

\footnotetext{
Art. $3^{\circ}$ A Educação Física é uma área de conhecimento e de intervenção acadêmico-profissional que tem como objeto de estudo e de aplicação o movimento humano, com foco nas diferentes formas e modalidades do exercício físico, da ginástica, do jogo, do esporte, da luta/arte marcial, da dança, nas perspectivas da prevenção de problemas de agravo da saúde, promoção, proteção e reabilitação da saúde, da formação cultural, da educação e da reeducação motora, do rendimento físico-esportivo, do lazer, da gestão de empreendimentos relacionados às atividades físicas, recreativas e esportivas, além de outros campos que oportunizem ou venham a oportunizar a prática de atividades físicas, recreativas e esportivas (BRASIL, 2004, p.01).
}

Percebemos, contudo, que a Educação Física é uma área ampla de conhecimento, em virtude disso a formação no curso de graduação (Bacharelado) é construída nas seguintes 
dimensões de conhecimento: a) Relação ser humano-sociedade; b) Biológica do corpo humano; c) Produção do conhecimento científico e tecnológico. Enquanto dimensões específicas a graduação consiste em: a) Culturais do movimento humano; b) Técnicoinstrumental c) Didático-pedagógica (BRASIL, 2004). Enquanto a habilitação de Licenciatura parte das seguintes dimensões: a) cultura geral e profissional; b) conhecimentos sobre crianças, adolescentes, jovens e adultos, aí incluídas as especificidades dos alunos com necessidades educacionais especiais e as das comunidades indígenas; c) conhecimento sobre dimensão cultural, social, política e econômica da educação; d) conteúdos das áreas de conhecimento que serão objeto de ensino; e) conhecimento pedagógico; f) conhecimento advindo da experiência (BRASIL, 2002).

Nunes, Votre e Santos (2012) organizaram essas dimensões num quadro comparativo, possibilitando distinguir as diferenças da formação em Licenciatura e Graduação (Bacharelado) (Quadro 5). Entretanto é de responsabilidade da IES a organização e a distribuição dos componentes curriculares nas dimensões de conhecimento (BRASIL, 2004).

Quadro 5 - Comparação das dimensões de conhecimento dos Cursos de Educação Física (Licenciatura e Bacharelado)

\begin{tabular}{|c|c|}
\hline \\
\hline Professor Licenciado do Ensino Básico & Profissional Bacharel em Educação Física \\
\hline Dimensões do Conhecimento & $\begin{array}{c}\text { Dimensões do Conhecimento } \\
\text { Conhecimentos identificadores da área }\end{array}$ \\
\hline \multirow{6}{*}{$\begin{array}{l}\text { - Conhecimento da Cultura geral e profissional; } \\
\text { - Conhecimento sobre criança, adolescentes, } \\
\text { jovens e adultos, incluindo as especificidades dos } \\
\text { alunos com necessidades educacionais especiais e } \\
\text { das comunidades indígenas; } \\
\text { - Conhecimento sobre dimensão cultural, social, } \\
\text { política e econômica da Educação; } \\
\text { - Conteúdos das áreas de conhecimento que serão } \\
\text { objeto de ensino; } \\
\text { - Conhecimento pedagógico; } \\
\text { - Conhecimento advindo da experiência. }\end{array}$} & Formação ampliada \\
\hline & $\begin{array}{l}\text { - Relação ser humano-sociedade; } \\
\text { - Biologia do Corpo; } \\
\text { - Produção do conhecimento científico e } \\
\text { tecnológico. }\end{array}$ \\
\hline & Formação Específica \\
\hline & $\begin{array}{l}\text { - Culturais do movimento humano; } \\
\text { - Técnico instrumental; } \\
\text { - Didático-pedagógica. }\end{array}$ \\
\hline & $\begin{array}{c}\text { Conhecimento identificador de } \\
\text { aprofundamento }\end{array}$ \\
\hline & $\begin{array}{l}\text { - Promoção da saúde; } \\
\text { - Lazer e aventura; } \\
\text { - Rendimento esportivo; } \\
\text { - Gestão e empreendimentos; } \\
\text { - Projetos sociais; } \\
\text { - Outros. }\end{array}$ \\
\hline
\end{tabular}

Fonte: Nunes, Votre e Santos (2012, p. 286)

A partir de uma análise mais detalhada nos anos de 2016 e 2017 para os cursos presenciais e EaD em Educação Física - Licenciatura e Bacharelado - em IES públicas e privadas, podemos verificar na tabela 8 o aumento do número de IES, de cursos, consequentemente, o número de matriculados e concluintes também cresceu. Essa progressão 
não aconteceu apenas no número de matriculados e concluintes nas IES públicas no curso de formação de professores. Apesar dessa diminuição de matriculados e concluintes no curso de Licenciatura em IES públicas, ainda no país há mais cursos nessa área e formam-se mais professores em Educação Física ao invés de profissionais que possam atuar na área da saúde e esportiva, como acadêmica, clubes, postos de saúde dentre outros.

Tabela 8 - Dados Gerais dos Cursos de Graduação Presenciais e a Distância de Educação Física - Brasil 2016 e 2017

\begin{tabular}{|c|c|c|c|c|c|c|c|c|}
\hline \multirow{3}{*}{$\begin{array}{l}\text { Tipo de IES } \\
\text { Categorias }\end{array}$} & \multicolumn{4}{|c|}{ Pública } & \multicolumn{4}{|c|}{ Privada } \\
\hline & \multicolumn{2}{|c|}{2016} & \multicolumn{2}{|c|}{2017} & \multicolumn{2}{|c|}{2016} & \multicolumn{2}{|c|}{2017} \\
\hline & Lic. & Bach. & Lic. & Bach. & Lic. & Bach. & Lic. & Bach. \\
\hline$N^{0}$ de IES & 105 & 70 & 103 & 72 & 391 & 364 & 409 & 425 \\
\hline $\mathrm{N}^{\circ}$ de Curso & 194 & 88 & 182 & 89 & 488 & 447 & 515 & 523 \\
\hline Matriculadoc & 34.30 & 16.39 & 34.47 & 17.61 & 151.25 & 103.03 & 151.32 & 130.53 \\
\hline Matricuiados & 3 & 8 & 0 & 6 & 1 & 1 & 2 & 5 \\
\hline Concluintes & 5.103 & 2.471 & 5.207 & 2.608 & 17.230 & 14.297 & 29.108 & 18.445 \\
\hline
\end{tabular}

Fonte: INEP $(2017 ; 2018)$

Lic. - Licenciatura

Bach. - Bacharelado

Ao comparar com outros cursos presenciais e a distância (IES pública e privada) de formação de professores de disciplinas profissionais ${ }^{1}$ a Educação Física apresenta, respectivamente, $71,49 \%$ e $76,80 \%(n=22.333-2016 ; n=34.315-2017)$ do total de concluintes dessa categoria $(n=31.235-2016 ; n=44.677-2017)$, enquanto o segundo curso com mais formandos é Artes Visuais $(n=2.280$ - 2016; $n=3.608$ - 2017). Ao confrontarmos com a categoria de matérias específicas ${ }^{2}$, o maior número de formandos se encontra nos cursos de História $(n=12.810-2016 ; n=12.859-2017)$ e Biologia $(n=12.447-2016$; n=12.634 - 2017), aproximadamente a metade ou mais identificados na Educação Física. Já os cursos de Pedagogia se enquadram na categoria das Ciências da Educação ${ }^{3}$, os quais apresentam mais concluintes $(n=125.099$ - 2016; $n=126.114$ - 2017) que o total dessas duas

\footnotetext{
${ }^{1}$ Categoria de análise pelo INEP $(2017 ; 2018)$ compostas pelos seguintes cursos de formação de professores em: artes (educação artística); artes plásticas; artes visuais; biblioteconomia; computação (informática); dança; disciplinas do setor primário (agricultura; pecuária etc.); economia doméstica; educação física; enfermagem; mecânica; música; teatro (artes cênicas); segurança pública; e educação profissional e tecnológica.

2 Categoria de análise pelo INEP $(2017 ; 2018)$ compostas pelos seguintes cursos de formação de professores em: biologia; ciências; filosofia; física; geografia; história; letras; língua/literatura estrangeira moderna; língua/literatura vernácula (português); língua/literatura vernácula e língua estrangeira moderna; matemática; química; e sociologia.

${ }^{3}$ Categoria de análise pelo INEP $(2016$; 2017) composta pelos seguintes cursos: Administração Educacional; Educação Organizacional; e Pedagogia.
} 
categorias - disciplinas profissionais $(n=31.235-2016 ; n=44.677-2017)$ e matérias específicas $(\mathrm{n}=82.276-2016 ; \mathrm{n}=81.452)$ (INEP, 2017; 2018).

Quanto à habilitação em Bacharelado em Educação Física, os cursos presenciais e a distância se enquadram na categoria Saúde e Bem-Estar Social ${ }^{4}$, na Tabela 9 foram organizados os cursos que apresentaram mais de 10.000 concluintes. Em relação aos formados dessa categoria, o curso de Educação Física, em 2015, ocupava o quinto lugar com maior número de concluintes, mas em 2016 e 2017 passou para terceiro lugar, ultrapassando Medicina e Farmácia. Também identificamos que o número de porcentagem representativa da categoria foi aumentando na Educação Física (9,23\% - 2015; 10,39\% - 2016; 11,97\% 2017) e diminuíram nos cursos de Enfermagem $(22,13 \%$ - 2015; 21,81\% - 2016; 21,25\% 2017) e Serviço Social $(19,33 \%$ - 2015; 18,22\% - 2016; 15,90\% - 2017), os quais apresentaram maior número de profissionais formados.

Tabela 9 - Número de Concluintes dos cursos presenciais e a distância da categoria de Saúde e Bem-Estar Social com mais de 10.000 formandos

\begin{tabular}{ccccccc}
\hline \multirow{2}{*}{ Categoria } & \multicolumn{2}{c}{$\mathbf{N}^{\mathbf{0}}$ de Concluintes } & \% do número total de concluintes \\
\cline { 2 - 7 } & $\mathbf{2 0 1 5}$ & $\mathbf{2 0 1 6}$ & $\mathbf{2 0 1 7}$ & $\mathbf{2 0 1 5}$ & $\mathbf{2 0 1 6}$ & $\mathbf{2 0 1 7}$ \\
\hline Saúde e Bem-Estar Social & 157.240 & 161.384 & 175.922 & 100 & 100 & 100 \\
\hline Curso & & & & & & 21,25 \\
\hline Enfermagem & 34.799 & 35.195 & 37.377 & 22,13 & 21,81 & 15,90 \\
\hline Serviço Social & 30.387 & 29.403 & 27.971 & 19,33 & 18,22 & 11,97 \\
\hline Educação Física & 14.521 & 16.768 & 21.053 & 9,23 & 10,39 & 9,02 \\
\hline Farmácia & 14.618 & 14.418 & 15.874 & 9,30 & 8,93 & 9,74 \\
\hline Medicina & 17.042 & 16.568 & 17.130 & 10,84 & 10,27 & 9,49 \\
\hline Odontologia & 12.891 & 14.545 & 16.687 & 8,20 & 9,01 & 9,73 \\
\hline Fisioterapia & 14.5051 & 15.326 & 17.116 & 9,22 & 9,50 & 8,30
\end{tabular}

Fonte: INEP $(2016 ; 2017 ; 2018)$

Ao longo da história da formação de profissionais de Educação Física no país, foram identificadas mudanças, principalmente na perspectiva de formação generalista, que buscava diferentes subáreas, para uma formação mais especialista, visando à atuação apenas na escola

${ }^{4}$ Categoria de análise pelo INEP (2016; 2017) compostas pelos seguintes cursos: enfermagem; análises toxicológicas; farmácia; farmácia de manipulação; ciência médica; medicina; odontologia; educação física; naturologia; saúde (programas ou cursos gerais); saúde pública; serviço social; tecnologia de radiologia; tecnologia oftálmica; fisioterapia; fonoaudiologia; nutrição; optometria; quiroprática; terapia ocupacional. 
e outra nos demais espaços (academias, clubes, etc.). A partir do desenvolvimento dos cursos de Educação Física identificado nos estudos do INEP (2016; 2017; 2018), percebemos a representatividade no cenário da formação profissional na área da Educação e da Saúde.

No entendimento de Alvarenga (2016), o surgimento e a consolidação dos cursos de formação em Educação Física (Licenciatura e Bacharelado), bem como os cursos de Bacharelado em esporte acontecerão a partir de reflexões, pesquisas e proposições sobre a formação. Isso significa a necessidade de discussões e estudos sobre a formação dos profissionais de Educação Física em todas as áreas de atuação que a profissão contempla, haja vista que a expansão dos cursos em $\mathrm{EaD}$, principalmente na formação de professores, é outro ponto importante a ser debatido, pois vem ganhando espaço no Ensino Superior, refletindo em sua representatividade na atuação profissional do contexto escolar.

Tal expansão dos cursos de Educação Física a distância não é um fenômeno exclusivo da área, conforme identificam Gatti e Barretto (2009), houve crescimento de forma acelerada dos cursos de formação de professores na categoria a distância. Ainda as autoras apontam que esse cenário está preocupando os estudiosos da Educação. Entretanto, conforme o decreto $n^{\circ} 6.755$ (BRASIL, 2009), é de responsabilidade da União, dos Estados, do Distrito Federal e dos Municípios a formação inicial e continuada dos profissionais do magistério para as redes públicas da Educação Básica. Ainda apontam como princípio no Art. 20 . "IV a garantia de padrão de qualidade dos cursos de formação de docentes ofertados pelas instituições formadoras nas modalidades presencial e à distância” (BRASIL, 2009, p. 01).

No entanto é possível identificar fragilidades na sociedade quanto à aprendizagem escolar, dessa forma colocam-se alguns pontos a serem refletidos nesse processo como: políticas educacionais, financiamento da Educação Básica, as culturas nacionais, regionais e locais dentre outros fatores. A formação de professores também é um aspecto a ser pensado, principalmente no que diz respeito à estrutura da instituição, aos currículos e aos conteúdos formativos (GATTI; BARRETTO; ANDRÉ, 2011). Também quanto aos princípios da Política Nacional de Formação de Profissionais do Magistério da Educação Básica (BRASIL, 2009, p. 01)

I - a formação docente para todas as etapas da educação básica como compromisso público de Estado, buscando assegurar o direito das crianças, jovens e adultos à educação de qualidade, construída em bases científicas e técnicas sólidas; II - a formação dos profissionais do magistério como compromisso com um projeto social, político e ético que contribua para a consolidação de uma nação soberana, democrática, justa, inclusiva e que promova a emancipação dos indivíduos e grupos sociais; [...] V - a articulação entre a teoria e a prática no processo de formação 
docente, fundada no domínio de conhecimentos científicos e didáticos, contemplando a indissociabilidade entre ensino, pesquisa e extensão [...]

Isto é, a formação dos professores está fundamentada conforme a legislação vigente, apontando principalmente os princípios e deveres institucionais. Contudo ainda é possível identificar distintas lacunas na prática dessa formação, as quais merecem ser refletidas e modificadas. Neira $(2016 ; 2017)$ aponta a importância de discussões e investigações sobre os currículos que formam professores de Educação Física. O autor ainda revela que há ausência de criticidade nas disciplinas ao longo da formação inicial, principalmente nas disciplinas biológicas, o que leva à formação de profissionais acríticos e reprodutores, favorecendo apenas conhecimento das técnicas e fundamentos sobre o corpo (NEIRA, 2017). Além de associar a função social da Educação Física apenas com a preparação física e promoção de um estilo de vida estipulados como padrões (NEIRA, 2016; 2017).

Os estudos de Colombo e Cardoso (2008), Alvino Junior e Neira (2013), Alvino Junior (2016), entretanto, apontam que os Projetos Pedagógicos dos Cursos descrevem a preocupação em formar profissionais críticos e cidadãos que contribuam para o desenvolvimento da sociedade. Certamente, isso se encontra em diversos projetos de distintos cursos de formação profissional, não apenas da Educação Física. No entanto induz ao questionamento se na prática diária acontece realmente isso e de que forma, principalmente se os estudantes conseguem abstrair esse tipo de formação. Na pesquisa de Colombo e Cardoso (2008) foi possível identificar que sim, os egressos do curso de Licenciatura em Educação Física de uma IES privada conseguiram compreender que sua formação inicial contribuiu para a formação crítica frente à realidade social, afirmando que:

[...] propiciou discussões relevantes no que concerne a realidade social na qual vivemos, se aproximando de alguns objetivos na qual prioriza, como a formação de um ser crítico que conheça a realidade à sua volta para poder intervir sobre ela, tendo a possibilidade de transformar a sociedade na qual está inserido (COLOMBO; CARDOSO, 2008, p. 125).

Sabemos, entretanto, que a realidade da formação inicial em Educação Física (Bacharelado e Licenciatura) apresenta algumas dificuldades para alcançar essa articulação identificada por Colombo e Cardoso (2008), principalmente devido à estruturação do currículo e suas problemáticas apontadas por Neira (2016; 2017). O último parecer DNCs da Educação Física (Parecer 584/2018) aponta a importância de compreender as problemáticas e desafios sociais contemporâneos, principalmente relacionadas à saúde e à Educação, a fim de desenvolver competências, habilidades e atitudes necessárias para uma formação de 
qualidade voltada para o Sistema Único de Saúde (SUS) e para a formação de professores de todas as áreas de atuação profissional (BRASIL, 2018a). Esse documento apresenta como objeto e objetivo geral:

a) Objeto das Diretrizes Curriculares: currículos que possam construir o perfil acadêmico e profissional com competências, habilidades, atitudes e conhecimentos, dentro de perspectivas e abordagens contemporâneas de formação pertinentes e compatíveis com referenciais nacionais e internacionais, capazes de atuar com qualidade, eficiência e resolubilidade nos espaços de atuação do graduado em Educação Física, considerando os avanços científicos e tecnológicos do Século XXI.

b) Objetivo Geral das Diretrizes Curriculares: favorecer aos alunos do curso de graduação em Educação Física sólida formação teórico-prática, interdisciplinar e humanista, garantindo a formação de profissionais com autonomia, ética, discernimento e criticidade, de forma que se assegure a integralidade da atenção em saúde e em educação, e a qualidade e humanização do atendimento prestado aos indivíduos, famílias e comunidades (BRASIL, 2018a, p. 04)

A partir dessa perspectiva, preocupa-se em desenvolver uma proposta que favoreça a flexibilidade, a diversidade e qualidade da formação, distanciando da visão de transmissão de conhecimento e informações. Busca também uma formação geral e específica ao egresso com o intuito de contribuir para o desenvolvimento profissional ao longo dos desafios e transformações na sociedade (BRASIL, 2018a).

É possível perceber a busca pela mudança e melhoria na formação desse profissional, no entanto não há como negar a presença significativa da questão do poder na construção e reconstrução das Diretrizes Curriculares. Isso advém dos interesses econômicos e culturais relacionados ao acesso e à permanência dos estudantes na formação inicial (NUNES, 2016), tal realidade também pode ser vista pelo crescente número de surgimento de cursos, principalmente instituições privadas, seja em cursos presenciais ou $\mathrm{EaD}$.

Na perspectiva de Nunes (2011; 2016), o currículo na formação inicial em Educação Física está fundamentado na área da Saúde e no ensino de técnicas corporais hegemônicas, associado ao consumo das práticas corporais e enfatizando a visão alienada exposta pelos meios de comunicação. Ainda complementa que "[...] favorece a circulação dos ideais neoliberais em meio ao jogo cambiante das Diretrizes, do órgão regulador do profissional da área, das suas práticas e dos conhecimentos que divulga" (NUNES, 2016, p. 42).

Tal afirmação de Nunes (2016) advém de sua pesquisa realizada sobre currículo na formação inicial de professores de Educação Física em 2010, identificando que os componentes curriculares abordam conhecimento associados a questões biológicas do corpo humano, destacando a tecnociência e suas potencialidades (NUNES, 2011). 
Suplementos alimentares, vitaminas, drogas químicas, hipertrofia muscular, sistemas de alavancas, além da classificação, descrição, composição e função dos tecidos morfológicos, princípios de treinamento etc. são temas abordados nas aulas, produzindo e transmitindo significados culturais que naturalizam representações acerca das intervenções possíveis de serem feitas pelo profissional de EF sobre o corpo de seus sujeitos-alunos, sujeitos-clientes. Essas representações ganham força com as distintas hierarquizações que este corpo manipulável pode alcançar (NUNES, 2011, p. 196).

Além disso, o autor aponta que há contradição entre o discurso sobre o currículo da Educação Física, pois busca a inclusão, no entanto, aponta sobre o corpo saudável compactuando com a perspectiva de padronização corporal. Tal postura permite com que ocorra a construção de identidade a partir de valores e características repressivas de ordem social, enfatizando outras formas de distinções entre os sujeitos (NUNES, 2011).

A investigação de Brugnerotto e Simões (2009), ocorrida antes de Nunes (2016) sobre os currículos na Formação em Educação Física, também aponta sobre o fator da influência do poder na construção do currículo, considerando-o instrumento que representa as classes de interesse. No entanto Nunes (2016) critica a presença da perspectiva sobre a saúde inserida nos currículos, fundamentada no consumismo, haja vista que Brugnerotto e Simões (2009) defendem a melhoria da visão sobre a saúde, voltada para prevenção de doenças e mudança de estilo de vida, isto é, promoção da saúde. Além disso, apresentaram alguns resultados interessantes:

- ao analisar o conceito de saúde presente em 12 currículos de formação em Educação Física das principais universidades do Estado do Paraná (seis Licenciatura e seis Bacharelado), identificaram que os cursos de Bacharelado apresentam componentes curriculares que contêm no título e/ou na ementa os termos "saúde", "saúde coletiva" e/ou "saúde pública", enquanto nos cursos de Licenciatura encontraram três componentes. Assim concluindo "[...] mostra que não houve consenso sobre a questão de como o professor vai agir na escola, e fora dela, sob o ideário da Promoção da Saúde. Tal atitude pode ser interpretada como se as ações de saúde não fizessem parte do currículo escolar, apesar de estarem contidas nos documentos oficiais [...]" (BRUGNEROTTO; SIMÕES, 2009, p.157);

- Cursos que apontaram sobre a inserção da saúde no componente curricular apresentaram abordagens diferentes, em duas universidades a Licenciatura está com enfoque humanista e um biológico. Enquanto nos seis cursos de Bacharelado ficou centrado numa perspectiva biológica voltada à ação do profissional da Educação Física (BRUGNEROTTO; SIMÕES, 2009); 
- Consideram que "teoricamente" os projetos político-pedagógicos dos cursos correspondem ao movimento sobre Promoção da Saúde, mas precisam amadurecer o verdadeiro significado dentro da Educação Física, haja vista a área que contribui para prevenção de doenças e mudança de estilo de vida saudável. Também sugerem repensar a interpretação sobre saúde inserida nos currículos e propõem estudos que relacionem prática profissional e o que fora abordado no currículo (BRUGNEROTTO; SIMÕES, 2009).

A afirmação de Nunes $(2011 ; 2016)$ nos permite compreender que a concepção de saúde não foi repensada e aprimorada, principalmente a formação de professores de Educação Física, conforme Brugnerotto e Simões (2009) apontam em seu estudo. Em contrapartida, no relato de Vilarta e Gutierrez (2013) identificamos um movimento almejado por Brugnerotto e Simões (2009), os quais descrevem inicialmente a contribuição significativa da Educação Física no viés da saúde e a implementação de um currículo voltado à saúde e qualidade de vida.

O primeiro viés consiste no estilo de vida pessoal, voltado à atenção individualizada, à performance ou à recuperação de aptidão física de cardíacos. Os autores reconhecem a dificuldade de trabalhar com esse público devido à presença distinta de referenciais e parâmetros de valorização social, mas partem do pressuposto de que é preciso adotar hábitos de vida saudáveis, mudanças de valores, realizar o acolhimento familiar e social dos novos hábitos. Essa perspectiva tem a preocupação central na saúde e no bem-estar físico, mental e social (VILARTA; GUTIERREZ, 2013).

$\mathrm{Na}$ segunda, abordagem sobre política, destacam a questão governamental associada ao esporte e à atividade física, a prática no campo da comunidade e da escola. Exemplificam com os projetos de pesquisa-ação e de extensão universitária, os quais buscam o envolvimento de diferentes profissionais, bem como dos acadêmicos, a fim de contribuir para a própria formação profissional. Nesses projetos não visavam o empoderamento sobre a saúde associado ao corpo, mas sim buscam melhorias na qualidade de vida a partir das atividades culturais, discussões sobre temas atuais, sobre saúde dos escolares, família, escola e esporte, dentre outras ações (VILARTA; GUTIERREZ, 2013).

A terceira dimensão refere-se à gestão relacionada às situações internas de estresse e de doenças profissionais. Nesse quesito associa-se aos agravos desenvolvidos em ambiente laboral, isto é, de trabalho, sejam físicas e/ou emocionais que a Educação Física vem intervindo a partir da Ginástica Laboral, por exemplo (VILARTA; GUTIERREZ, 2013). 
Vilarta e Gutierrez (2013) descrevem também suas experiências na estruturação curricular dos conteúdos da Educação Física e saúde na Universidade Estadual de Campinas - UNICAMP - a partir das Diretrizes Curriculares Nacionais de Educação Física (BRASIL, 2004) para o desenvolvimento do conhecimento de conteúdos teóricos e aplicados à saúde coletiva. Verificaram que os componentes compositivos dessa área tinham como base a compreensão e valorização da ciência da epidemiologia.

\begin{abstract}
Nesse ponto, fundamentadas e discutidas as informações conceituais sobre a ciência epidemiológica, seus termos específicos, processo saúde-doença, DCNT [doença crônica não transmissíveis - grifo do autor], transição sociodemográfica, históricos sanitário brasileiro, promoção da saúde, mudanças comportamental, estilo de vida saudável, nossos alunos passam a olhar as possibilidade de desenvolvimento de competências próprias da Educação Física, a partir do conhecimento e da avaliação das realidades sociais nas quais atuam profissionais da Educação Física em ação interdisciplinar com demais profissionais da área da saúde (VILARTA; GUTIERREZ, 2013, p. 225).
\end{abstract}

Percebemos que os autores defendem perspectivas distintas sobre o currículo na formação de profissionais de Educação Física, principalmente, de professores, assim evidenciando a predominância do poder nesse processo de construção curricular. Tal divergência está associada ao olhar e aplicação dos conceitos e perspectivas na formação conforme o interesse e vivência daqueles que constroem o currículo, sem identificar a real necessidade da sociedade, das divergências culturais. Nas instituições privadas, principalmente, devido à logística da grade curricular, as quais acabam desenvolvendo o mesmo componente curricular na formação de Licenciatura e Bacharelado, sem mesmo fazer a distinção das necessidades conforme cada campo de atuação.

No estudo de Neira (2009), a partir da análise da documentação pedagógica na formação de professores de Educação Física, verificamos que os planos e as atividades de ensino dos docentes universitários objetivavam a melhoria da aptidão física e motora, também realizam exames biométricos dentre outras propostas fundamentadas nos conhecimentos biológicos. Assim compartilha com a mesma perspectiva de Nunes (2011; 2016) de que os currículos buscam padrões culturais associados a certos estilos de vida, por exemplo:

[...] a emissão de discursos de combate à obesidade infantil por parte dos professores de formação biológica. Sem criticidade alguma no tocante às condições de vida das populações escolares e, revelando um profundo desconhecimento das funções e objetivos da Educação Física escolar, em suas aulas, defendem o aumento do tempo de atividade física para os estudantes [...] (NEIRA, 2009, p. 130). 
Além disso, foi identificado que o currículo está associado a manifestações esportivas euro-americanas tradicionais e midiáticas centradas nos esportes, ginásticas, danças, lutas e brincadeiras relacionadas ao sensorial. Isso reflete em alguns pontos importantes: a ausência de possibilidade da vivência nas modalidades radicais, urbanas, rurais, de aventura, dentre outras proporcionadas em diferentes contextos; a inclusão fica integrada ao longo das disciplinas com pouca atenção; ocultação da relação de poder inserida no percurso histórico das manifestações corporais, cujos sujeitos são os produtores e reprodutores desse patrimônio cultural, suas vidas, seus valores e suas ideias (NEIRA, 2009).

Miranda (2013) menciona que as investigações buscam retratar a formação em Educação Física para área escolar e correspondentes contextos a partir das novas formas de estruturação, propostas curriculares dentre outros aspectos que desviem o olhar dos modelos formativos obsoletos: mecanicista, esportivista e tradicional. Enfatiza que a sociedade precisa de professores que ultrapassem a barreira do conteúdo, possibilitando articular os aspectos sócio-históricos e políticos, isto é:

precisamos de um professor que atenda às mudanças sociais com capacidades de refletir, agir e transformar. Neste sentido, a formação acadêmico-profissional deveria possibilitar aos futuros professores não apenas uma intervenção competente, de caráter técnico-instrumental, mas também a capacidade de articular os seus conhecimentos teórico-metodológicos na dinâmica das diferentes realidades (MIRANDA, 2013, p. 24830).

Na matriz curricular dos cursos de Licenciatura e Bacharelado em Educação Física, no estado do Paraná, foi identificada que, respectivamente, $23,4 \%$ e $26 \%$ da carga horária total dos cursos compõem a dimensão cultural do movimento humano, isto é, a dimensão com maior representatividade. Tal resultado pode advir, primeiramente, dos componentes curriculares encontrados historicamente nos cursos, também por apresentar conhecimentos que contemplem as especificidades da Educação Física - jogos e brincadeira, esportes, lutas, danças e ginásticas (PIZANI; BARBOSA-RINALDI, 2014).

Nesse estudo de Pizani e Barbosa-Rinaldi (2014) também foi constatado que a matriz curricular dos cursos de Bacharelado contempla mais a dimensão técnico-instrumental (24\%) e nos cursos de Licenciatura foi a dimensão didático-pedagógica (21,3\%). Assim evidenciase que a formação de professores apresenta questões pedagógicas que estão após as dimensões específicas associadas à Educação Física, pois a dimensão cultural do movimento humano predomina. Nos cursos do Bacharelado a segunda dimensão em destaque foi a técnico-instrumental, conforme as autoras, condiz com a formação desse profissional, haja 
vista a necessidade de conhecimentos referentes às bases teóricas e metodológicas ao desempenho humano, ao desenvolvimento humano, comportamento motor, à psicologia etc., tornando-se essencial para atuação fora dos ambientes escolares (Figura 4).

Figura 4 - Percentual de distribuição da carga horária das disciplinas dos cursos de licenciatura e bacharelado em Educação Física por dimensão do conhecimento e das atividades complementares como parte da carga horária total do currículo

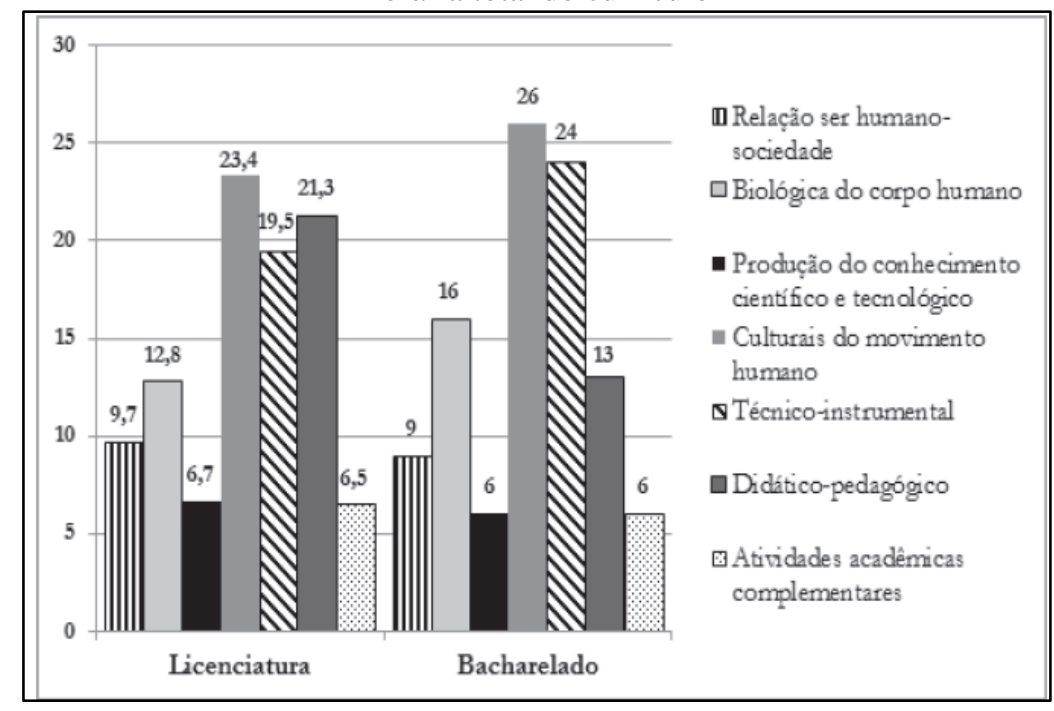

Fonte: Pizani e Barbosa-Rinaldi (2014, p. 676)

Além das distintas concepções sobre a estruturação do currículo na formação de profissionais de Educação Física, ele deve ser constituído de forma coletiva a partir do colegiado composto pelos docentes, bem como ser constantemente reavaliado, pois há necessidade de compreender o espaço de atuação profissional que está em constante mudança (NEIRA, 2009; MASETTO, 2015a). Também é preciso definir a perspectiva de homem, mulher, mundo, sociedade e área de conhecimento, dessa forma poderão propor conteúdos, atividades e métodos de ensino que contribuam na construção das identidades dos profissionais que almejam formar (NEIRA, 2009).

Nesse quesito ocorre a falha na formação de professores de Educação Física conforme Neira (2009), pois os docentes que constroem o currículo estão distantes da Educação Básica, alguns não possuem a vivência no ambiente escolar, exceto como aluno, assim reproduzindo o que foi aprendido. Caso os futuros professores obtenham formação nessa perspectiva sofrerão carência de conhecimentos associados a questões sócio-históricas e políticas, bem como poderão se afastar da atual função social da escola (NEIRA, 2009).

Nessa mesma concepção sobre a constituição coletiva do currículo (NEIRA, 2009; MASETTO, 2015a) e sobre a relação do poder nesse processo (NEIRA, 2009; NUNES, 2016), Alvino Junior $(2011 ; 2016)$ investigou a construção curricular em um curso de uma 
IES privada, a qual compunha a Licenciatura Ampliada (Licenciatura e Bacharelado), isto é, forma profissionais de Educação Física para atuarem dentro e fora do ambiente escolar. Nesse estudo Alvino Junior $(2011 ; 2016)$ verificou algumas questões importantes que identificam poder ser um processo de construção coletiva, mas não democrático, e devem ser refletidas pelos professores que atuam no Ensino Superior ao realizarem ou reconstituírem o currículo para a formação de profissionais de Educação Física, atuante ou não na escola:

- tornou-se um espaço de disputa de poder entre os docentes, os quais procuram conquistá-lo no novo currículo, assim resultando num ambiente pouco democrático;

- a ausência dos estudantes ao longo do processo da construção reafirmou a característica do espaço mencionada, bem como evidenciou a hierarquização na relação entre o professor e aluno;

- o distanciamento da realidade profissional ao deixar a construção do currículo associadas às necessidades políticas, centradas mais aos interesses administrativos do que pedagógico.

Além dessas preocupações, que contornam a formação do professor de Educação Física, sobre a construção de um currículo que ultrapasse os aspectos conteudistas e aproxime a formação a partir de competências de saber, sabe-fazer, saber-ser e saber-tornar-se, existe a preocupação com a dissociação da teoria e da prática, levando ao impacto dos estudantes na inserção profissional. Ao longo da formação inicial, deparamo-nos com discursos sem fundamentos críticos e construtivos referentes à docência, denominados ingênuos e desconectados da realidade sobre o aluno, funcionamento da escola e dos professores (NEIRA, 2014). Em virtude disso, Farias et al. (2008, p. 310) acreditam que "os cursos de Licenciatura necessitam propor, nas disciplinas ministradas, elementos da profissionalidade docente, a fim de que o estudante possa adquirir ou acrescentar no seu fazer pedagógico as crenças, os valores e as atitudes do ser docente".

O distanciamento da formação acadêmica com realidade profissional, todavia, leva à visão dicotômica da teoria-prática, mas também não é uma problemática exclusivamente da Educação Física. O futuro profissional, ao inserir-se no campo de atuação, apresenta dificuldades de aplicação da teoria, principalmente na solução dos problemas. E no caso do professor, isso o leva ao discurso ilusório de que se aprende a docência a partir das experiências advindas da prática, perspectiva utópica, pois toda prática pedagógica possui uma teoria que a sustenta (DORNELES; SHIGUNOV; NASCIMENTO, 2012).

Vislumbrando tal problemática, a qual não é recente na Educação Física, a Resolução CNE/CES/07/2004 dispõe, a partir do que Art. 10: “A formação do graduado em Educação 
Física deve assegurar a indissociabilidade teoria-prática por meio da prática como componente curricular, estágio profissional curricular supervisionado e atividades complementares" (BRASIL, 2004, p. 04). Isto é, o estudante tem a possibilidade das vivências práticas desde o início da graduação a partir das práticas como componente curricular (PCC) e atividades complementares de forma simultânea aos trabalhos teóricos desenvolvidos ao longo da formação. Esses procedimentos possibilitam aproximações da teoria com a prática, bem como evitam o choque com a realidade ao iniciar o estágio supervisionado, identificando a realidade da Educação Física. O professor-formador, no caso, faz um papel importante nesse processo, pois fomenta as aproximações em diferentes espaços de formação, mas a PCC precisa ser planejada e acompanhada, a fim de atingir seus propósitos dentro do currículo (AFONSO; NOCCHI; OST, 2012).

O estágio supervisionado também busca esse estreitamento com a realidade profissional. Não obstante Sodré e Neira (2011) descrevem sobre tal importância na formação inicial, pois permite ao estudante discutir e refletir junto à universidade (professores e colegas) e com professores supervisores de estágio sobre as situações-problema vivenciadas, assim como permite a troca de experiência e a construção de novos conhecimentos de todos os envolvidos.

Enfim, o currículo na formação inicial, seja em Educação Física ou não, pode ser compreendido a partir das teorias tradicionais, crítica e pós-crítica, dependerá dos protagonistas desse processo de construção curricular, os professores, e as questões de poder que neles estão impregnadas. Masetto (2015a), por exemplo, aponta que, no Ensino Superior, o currículo é identificado, normalmente, pelos seus docentes das seguintes formas: a) conjunto de disciplinas que têm como função a transmissão do conhecimento aos futuros profissionais, as quais são distribuídas por semestre ou ao longo do ano letivo; b) conhecimentos emergentes, habilidades desenvolvidas pelos estudantes e valores discutidos ao longo da aula, os quais não estão prescritos nos documentos formais, denominado "currículo oculto"; c) conjunto de conhecimentos, saberes, competências, habilidades, experiências, vivências e valores que os estudantes necessitam adquirir e desenvolver ao longo da formação inicial a partir de atividades de ensino e situações de aprendizagem (MASETTO, 2015a).

A divergência de concepções sobre o currículo existe, isso é fato, tais concepções estão sustentadas por diferentes perspectivas, realidades e experiências daqueles que o constroem. Na formação inicial em Licenciatura e Bacharelado em Educação Física a discussão ainda é mais complexa sobre esse tema, devido ao espaço de atuação desses 
profissionais. Entretanto, independentemente do curso de formação, os docentes são agentes importantes nesse processo de construção curricular, pois identificam e compreendem a realidade dos estudantes, o meio social em que vivem e o espaço de atuação, após a formação, permitindo-lhes ultrapassar os muros da universidade. Além disso, reconhecer o desenvolvimento científico e tecnológico que contribui para o desenvolvimento da sociedade; afastar-se da individualidade dos componentes curriculares, os quais precisam estar relacionados, a fim de contribuir na formação profissional. Os alunos e professores precisam ser agentes ativos dentro desse processo, pois se reconhece a ausência do conhecimento por ambos os envolvidos (MASETTO, 2015a).

\subsection{FORMAÇÃO CONTINUADA}

O desenvolvimento profissional ocorre a partir: a) do crescimento individual, ou seja, do pessoal; b) da profissionalização, permitindo aquisição de competência, eficácia de ensino e da organização do processo de ensino-aprendizagem; c) da socialização profissional, favorecendo o docente a adaptar-se no próprio ambiente profissional à luz dos termos normativos e interativos (GONÇALVES, 2000). É ao longo desse desenvolvimento, contudo, que a formação continuada está inserida, pois possibilita a busca de novos conhecimentos, bem como aperfeiçoamento de competências e habilidades adquiridas ao longo do percurso profissional: seja na formação inicial e/ou no cotidiano docente (ROMANOWSKI; MARTINS, 2010).

Inicialmente, a formação continuada surge a fim de suprir as lacunas encontradas na prática pedagógica dos professores resultante da formação inicial (ROMANOWSKI; MARTINS, 2010; DAVIS et al., 2012). Por isso o Instituto Nacional de Estudos Pedagógico (INEP) foi criado, em 1937, com o intuito de realizar investigações sobre a Educação Brasileira, também desenvolve cursos de formação continuada nas distintas regiões brasileiras. A partir disso, a formação começou a obter restaurações conforme os aspectos profissionais, sociais e políticos do país (ROMANOWSKI; MARTINS, 2010).

Atualmente, a formação continuada, conforme a LDB (BRASIL, 2017), é garantida aos profissionais da Educação, podendo ser realizada no local de trabalho e instituições de Educação Básica e Superior, seja curso de educação profissional, curso superior de graduação plena ou tecnológico e de pós-graduação. Embora o conceito ainda não esteja precisamente definido, conforme Gatti (2008) e na perspectiva da autora, é possível olhar essa formação à luz da concepção de qualquer atividade que contribua para o desempenho profissional, sejam: 


\begin{abstract}
horas de trabalho coletivo na escola, reuniões pedagógicas, trocas cotidianas com os pares, participação na gestão escolar, congressos, seminários, cursos de diversas naturezas e formatos, oferecidos pelas Secretarias de Educação ou outras instituições para pessoal em exercício nos sistemas de ensino, relações profissionais virtuais, processos diversos a distância (vídeo ou teleconferências, cursos via internet etc.), grupos de sensibilização profissional enfim, tudo que possa oferecer ocasião de informação, reflexão, discussão e trocas que favoreçam o aprimoramento profissional, em qualquer de seus ângulos, em qualquer situação. Uma vastidão de possibilidades dentro do rótulo de educação continuada (GATTI, 2008, p. 57).
\end{abstract}

Além desses exemplos abordados por Gatti (2008), os autores Pinto, Barreiro e Silva (2010) também apontam outras modalidades que contribuem para a prática docente e seu desenvolvimento profissional, além das descritas, quais sejam: cursos de pós-graduação lato sensu e stricto sensu, bem como processos permanentes proporcionados dentro ou fora da escola. Assim foi possível verificar a amplitude da formação continuada, pois é pautada na diversificação de sua forma e conteúdo. Tal situação ocorre porque os professores atuantes na Educação Básica não possuem formação superior, desse modo surgem os cursos de graduação presencial ou a distância aos professores em serviço. Ainda mais, a formação continuada visa, em sua maioria, contribuir para a atuação profissional dos professores titulados, em todos os níveis de ensino, possibilitando suprimento, atualização, treinamento, aprofundamento e pesquisa (ROMANOWSKI; MARTINS, 2010).

Em virtude dessa gama de ações que contempla a formação continuada, vimos a necessidade de abordá-la, pois sabemos que a formação do professor não se resume apenas à formação inicial. É necessário que o docente permaneça atualizado e buscando novos conhecimentos para o desenvolvimento qualificado de suas práticas pedagógicas (FARIAS; SHIGUNOV; NASCIMENTO, 2001). Desse modo o presente estudo escolheu abordar as seguintes modalidades da formação continuada: pós-graduação, a qual consiste em programas de mestrado e doutorado (stricto sensu), especialização (lato sensu) e cursos e programas de aperfeiçoamento e demais modalidades voltadas aos profissionais formados em cursos de graduação devidamente reconhecidos (BRASIL, 2017).

Discutiremos, inicialmente, sobre a pós-graduação stricto sensu, pois consideramos a formação primordial aos docentes atuantes no Ensino Superior, foco deste estudo. Em virtude disso, buscamos conhecer brevemente o percurso histórico, percebendo que sua criação contribuiu para o crescimento na área da Educação Física, pois, em 1977, surge o primeiro programa de mestrado e em 1989 o de doutorado, ambos pela Universidade de São Paulo (TANI, 2000). 
Foi no período de 1996 e 2000, entretanto, que o crescimento dos Programas de PósGraduação em Educação Física - PGEF - ocorreu de forma semelhante ao sistema nacional, mas isso não condiz com a produção intelectual (KOKUBUN, 2006). No final de 2003 havia 10 programas recomendados pela CAPES, contemplando 10 cursos de mestrado e seis de doutorado em 22 áreas de concentração; em junho de 2006, havia 17 cursos de mestrado e sete de doutorado (KOKUBUN, 2006).

No ano de 2017, a partir da Plataforma Sucupira (2018b), de acordo com a área de avaliação da Educação Física, pudemos identificar a inserção de programas da área básica Educação Física, Fisioterapia e Terapia Ocupacional e Fonoaudiologia, levando ao entendimento a amplitude da Educação Física na área da saúde. Ainda vale destacar que esses programas e cursos envolvem distintos títulos, entre eles: ciência do movimento, ciência da motricidade, ciência do esporte, ciência do movimento humano e Educação Física. Ao comparar com a análise de Kokunbun (2006), houve um aumento significativo em sua totalidade quanto à inserção da Educação Física no campo da pós-graduação, bem como sua expansão, adentrando na multidisciplinaridade, o que permitiu esse crescimento. É possível verificar a representatividade dos cursos e programas envolvidos na área de avaliação da Educação Física na tabela 10.

Tabela 10 - Programas de Pós-Graduação stricto sensu em funcionamento de acordo com área de avaliação da Educação Física

\begin{tabular}{c|c|c|c|c|c|c|c|c|c|c|c|c}
\hline $\begin{array}{c}\text { Cursos e } \\
\text { Programas } \\
\text { Nome }\end{array}$ & \multicolumn{7}{c|}{ Total de Programas de pós-graduação } & \multicolumn{3}{c}{ Totais de Cursos de pós-graduação } \\
\hline & $\mathrm{T}$ & $\mathrm{ME}$ & $\mathrm{DO}$ & $\mathrm{MP}$ & $\mathrm{DP}$ & $\begin{array}{c}\text { ME/ } \\
\text { DO }\end{array}$ & $\begin{array}{c}\text { MP/ } \\
\text { MD }\end{array}$ & $\mathrm{T}$ & $\mathrm{ME}$ & $\mathrm{DO}$ & $\mathrm{MP}$ & $\mathrm{DP}$ \\
\hline $\begin{array}{c}\text { Educação } \\
\text { Física }\end{array}$ & 37 & 13 & 0 & 2 & 0 & 22 & 0 & 59 & 35 & 22 & 3 & 1 \\
\hline $\begin{array}{c}\text { Fisioterapia e } \\
\text { terapia } \\
\text { ocupacional }\end{array}$ & 26 & 15 & 0 & 1 & 0 & 10 & 0 & 36 & 25 & 10 & 1 & 0 \\
\hline Fonoaudiologia & 10 & 2 & 0 & 1 & 0 & 7 & 0 & 17 & 9 & 7 & 1 & 0 \\
\hline Totais & 73 & 30 & 0 & 4 & 0 & 39 & 0 & 112 & 69 & 39 & 5 & 1 \\
\hline
\end{tabular}

Fonte: Plataforma Sucupira (2018b)

ME - Mestrado acadêmico

DO - Doutorado acadêmico

ME/DO - Mestrado e Doutorado acadêmico

MP - Mestrado Profissional

DP - Doutorado Profissional

MP/DP - Mestrado e Doutorado Profissional

$\mathrm{T}$ - Total 
É possível verificar, a partir das informações disponíveis na Plataforma Sucupira (2018b), que a incidência de oferta desses programas e cursos está centrada nas regiões sul e sudeste do país, isto é, de 60 cursos que correspondem à área Educação Física, dentro do sistema da Plataforma Sucupira, entre eles 32 (sudeste) e 16 (sul) se encontram nessas duas regiões brasileiras. Também podemos identificar que, na área básica da Educação Física, existem 33 universidades que oferecem programas e cursos de pós-graduação stricto sensu, considerando duas que se apresentam em mais de um campus. As universidades públicas em sua maioria $(n=29)$ ofertam esse tipo de formação, sendo mantidas pelo governo federal ou estadual.

O estudo de Brasileiro, Amaral e Paiva (2014) ainda apontam que as produções científicas dos professores do Ensino Superior atuantes nos cursos de Educação Física, nos estados da Paraíba e Pernambuco, originam das regiões sul e sudeste. Isto é, apesar do vínculo empregatício se localizar no nordeste do país, os docentes apresentam relações quanto à produção do conhecimento com pesquisadores e instituições das regiões sudeste e sul, onde se encontra maior número de programas e cursos de pós-graduação. Também se faz entender que há o crescimento de pós-graduação stricto sensu no nordeste brasileiro e que está sendo apoiado por instituições consolidadas nas outras regiões.

Quanto aos cursos registrados no EMEC (2017), pudemos identificar duas grandes áreas onde existem cursos de pós-graduação lato sensu em Educação Física: a) saúde e bemestar; b) Educação. Ao realizar a busca, inicialmente, foram encontrados 95 cursos ativos na primeira área e 179 na segunda. Ao analisá-los, primeiramente, foi possível identificar que há cursos com a modalidade presencial ou a distância. Quanto ao tema da especialidade, predominou sobre Educação Física Escolar, Metodologia do Ensino na Educação Física e Educação Física Inclusiva. A média da carga horária encontrada foi de 450 horas e a média de oferta de vagas são 200. A oferta, conforme a região do país, percebemos diversificada, considerando que algumas instituições oferecem em mais de um estado, ainda assim destacaram-se os seguintes estados: São Paulo, Espírito Santo; Distrito Federal; Goiás; Ceará; Minas Gerais; e Paraná.

A pesquisa de Novaes (2009) sobre o panorama e perspectiva da formação continuada em Educação Física quanto à pós-graduação lato sensu na Bahia aponta que, no período de 1992-2006, havia baixa incidência de teses e dissertações que discutiam sobre os cursos de especialização na Educação Física, bem como sobre a formação continuada nessa área. Ainda revela que os estudos estavam centrados na reunião sudeste e sul do país. Quanto aos temas abordados nesses cursos investigados na Bahia, discutiam aspectos inerentes à 
Saúde, Metodologia do Ensino da Educação Física e/ou Esporte e do Treinamento Desportivo.

Quanto à carga horária, os cursos de especialização que se encontram no sistema EMEC (2017) revelaram a média de horas maior que a mínima descrita na legislação vigente. Conforme estipulado do Art. $5^{\circ}$ da resolução $n^{\circ} 1$ de 2007, os cursos de pós-graduação lato sensu devem oferecer no mínimo 360 horas, sem computar o tempo de estudos individuais e coletivos, sem assistência docente, elaboração individual da monografia ou trabalho final de conclusão de curso (BRASIL, 2007).

Foi possível perceber no estudo de Novaes (2009) que há mais estudos e discussões sobre os cursos e programas stricto sensu em relação aos cursos lato sensu, mas ainda considerados inconsistentes, demonstrando lacunas sobre estudos que abordam sobre esses cursos na área de Educação Física. É possível evidenciar tal revelação de Novaes (2009) a partir do estudo realizado por Cruz Junior (2010) ao revelar que, no período de 2000 a 2009, foram publicados 1.199 artigos em quatro revistas da área de Educação Física, mas apenas 18 apresentaram relação com a formação continuada. Ainda mais, somente três trabalhos discutiram sobre a formação continuada relacionada aos cursos lato sensu - Bracht et al. (2002), Patriarca, Onofre e Mascarenhas (2008), e Belão, Machado e Mori (2009), conforme demonstra o Quadro 6.

Quadro 6 - Artigos que abordam sobre os cursos de pós-graduação lato sensu enquanto formação continuada na Educação Física fundamentado na pesquisa de Cruz Junior (2010)

\begin{tabular}{|c|l|}
\hline Artigos & \multicolumn{1}{c|}{ Tema de discussão } \\
\hline Bracht et al. (2002) & $\begin{array}{l}\text { Buscam descrever sobre avaliação da metodologia da pesquisa- } \\
\text { ação enquanto estratégia para a formação profissional continuada } \\
\text { num programa de pós-graduação lato sensu com vistas à promoção } \\
\text { de mudanças pedagógicas, bem como discute sobre os principais } \\
\text { obstáculos que se colocam para a mudança pedagógica. }\end{array}$ \\
\hline Patriarca, Onofre e & $\begin{array}{l}\text { Discutem sobre as crenças, as demandas e as relações com os } \\
\text { saberes que orientam os professores de Educação Física junto à } \\
\text { formação continuada proporcionada pelo curso de especialização } \\
\text { em Educação Física Escolar da Universidade Federal de Goiás. }\end{array}$ \\
\hline Belão, Machado e & $\begin{array}{l}\text { Abordam o nível de formação das técnicas que atuaram com } \\
\text { Ginástica Rítmica (GR) nos Jogos Regionais no ano de 2008 da 4 } \\
\text { Mori (2009) } \\
\text { Região do Estado de São Paulo, desde a formação inicial à } \\
\text { formação continuada }\end{array}$ \\
\hline
\end{tabular}

Fonte: Elaborado pela pesquisadora (2017) 
Em suma, cada investigação revela aspectos importantes sobre a formação continuada quanto aos cursos de especialização. Primeiramente, o estudo de Bracht et al. (2002) aponta para a contribuição do curso de pós-graduação lato sensu quanto à prática e formação crítica reflexiva à luz da utilização do método de pesquisa-ação. A investigação de Patriarca, Onofre e Mascarenhas (2008) revela que a procura por essa formação está imbricada: na busca de soluções das problemáticas da prática pedagógica; na necessidade de complementar o conhecimento adquirido na formação inicial; na atualização para realizar um concurso público, bem como os cursos stricto sensu. Ao passo que Belão, Machado e Mori (2009) consideram essencial a formação continuada enquanto cursos de especializações, oficinas e outros cursos específicos, pois as competências e habilidades desenvolvidas na formação inicial não sustentam as necessidades exigidas pela função de treinadora de GR.

Além desses estudos, a pesquisa de Salles, Farias e Nascimento (2015) comenta sobre a inserção profissional e a formação continuada de egressos dos cursos de Licenciatura e Bacharelado em Educação Física de uma universidade pública de Santa Catarina. Os autores puderam constatar que $79 \%(n=26)$ dos egressos do Bacharelado e $83 \% \quad(n=24)$ da Licenciatura apresentaram interesse em realizar esse tipo de formação, especificamente lato sensu (especialização) e stricto sensu (mestrado e doutorado). Os bacharéis em Educação Física apresentam em sua maioria interesse em realizar formação continuada na área da fisiologia do exercício, enquanto os licenciados optam por teoria e prática pedagógica. É importante salientar que o interesse em formações continuadas na área da promoção da saúde perpassou tanto bacharéis quanto licenciados.

Em virtude disso, o presente estudo também reconhece a importância de cursos e programas de aperfeiçoamento, bem como demais modalidades de formação continuada que contribuam para o desenvolvimento profissional dos professores de Educação Física. Além de reconhecer sua importância para a prática pedagógica dos docentes.

Atualmente, o Ministério da Educação (MEC) promove algumas ações que contemplam cursos e programas de aperfeiçoamento como formação continuada aos professores. Dentre elas destaca-se, inicialmente, a Rede Nacional de Formação Continuada de Professores, criada em 2004, com o objetivo de contribuir para a melhoria da formação dos professores e alunos, a partir de ações junto aos professores da Educação Básica da rede pública de ensino. Nessa rede, existem instituições públicas de Ensino Superior que produzem materiais para os cursos a distância e semipresenciais com a carga horária de 120 horas. As áreas de formação trabalhadas são: alfabetização e linguagem, educação matemática e científica, ensino de ciências humanas e sociais, artes e Educação Física. Além 
disso, o MEC proporciona suporte técnico e financeiro, bem como coordena o desenvolvimento do programa (REDE ..., 2017).

Os demais programas oferecidos pelo MEC não apresentam iniciativa voltada especificamente ao professor de Educação Física, e sim para docentes e profissionais atuantes na área da Educação. Em virtude disso, consideramos importante apresentar algumas ações de formação continuada com que os docentes de Educação Física podem se beneficiar.

O MEC dispõe do Programa Nacional de Formação Continuada em Tecnologia Educacional (ProInfo Integrado) que visa à utilização dos recursos didático-pedagógicos das Tecnologias da Informação e Comunicação (TIC) no cotidiano escolar, bem como proporciona a distribuição de equipamentos tecnológicos nas escolas. Além disso, esse programa disponibiliza conteúdos e recursos multimídia e digitais a partir do portal do professor, pela TV escola e DVD escola, pelo domínio público e pelo banco internacional de objetos educacionais. O programa tem como público-alvo professores e profissionais da rede pública de ensino, o qual também integra cursos e projetos (PROINFO INTEGRADO, 2017).

a) Introdução à Educação Digital (60h) - objetivo de contribuir para a inclusão digital de profissionais da educação;

b) Tecnologias na Educação: ensinando e aprendendo com as TICs (60h) - visa oferecer subsídios teórico-metodológicos práticos para que os professores e gestores escolares possam compreender o potencial pedagógico de recursos das Tecnologias de Informação e Comunicação (TIC) no ensino e na aprendizagem em suas escolas;

c) Elaboração de Projetos (40h): busca capacitar professores e gestores escolares para que eles possam: identificar as contribuições das TICs para o desenvolvimento de projetos em salas de aula; compreender a história e o valor do trabalho com projetos e aprender formas de integrar as tecnologias no seu desenvolvimento; analisar o currículo na perspectiva da integração com as TICs; planejar e desenvolver o Projeto Integrado de Tecnologia no Currículo (PITEC); utilizar os mapas conceituais ao trabalho com projetos e tecnologias, como uma estratégia para facilitar a aprendizagem;

d) Redes de Aprendizagem (40h): o objetivo é preparar os professores para compreenderem o papel da escola frente à cultura digital, dando-lhes condições de utilizarem as novas mídias sociais no ensino;

e) Projeto UCA (Um Computador por Aluno): ministrado pelas instituições de ensino superior e secretarias de educação, procura preparar os participantes para o uso dos 
programas do laptop educacional e propor atividades que proporcionem melhor entendimento de suas potencialidades;

Além desse programa referido, também oferece um ambiente virtual colaborativo de aprendizagem denominado e-Proinfo, o qual disponibiliza cursos a distância, complemento a cursos presenciais, projetos de pesquisa, projetos colaborativos e distintas ações de apoio a distância e ao processo ensino-aprendizagem (FORMAÇÃO ..., 2017). Há diversas instituiçõos vinculadas ao e-Proinfo como universidades, prefeituras e estados dentre outras, mas destaca-se na área da Educação Física: Academia Paralímpica Brasileira; CBAt Confederação Brasileira de Atletismo; CBBd - Confederação Brasileira de Badminton; Instituto Península - Instituto Península; ME - Ministério do Esporte. Então, nessa ação de formação continuada, há o desenvolvimento de aspectos específicos da Educação Física.

Além dessas possibilidades de formação continuada propostas pelo MEC, também optamos por descrever dois estudos que abordam e retratam a realidade dessa formação no contexto brasileiro, na modalidade de cursos e programas de aperfeiçoamento, bem como aspectos gerais que envolvem a Educação Física. A escolha pelos trabalhos científicos foi intencional, pois a essência e os resultados adquiridos ao longo das pesquisas articulam com o objeto de estudo deste relatório de tese.

Primeiramente, abordaremos a pesquisa que resultou na tese de Bahia (2016), a qual objetivou analisar a contribuição das ações de formação continuada em exercício para a carreira e a prática pedagógica dos professores de Educação Física, que atuam na Educação Básica no estado da Bahia. Participaram do estudo 65 professores da rede pública de ensino que estavam realizando o curso de pós-graduação lato sensu - Metodologia em Educação Física e Esporte - na Universidade Estadual de Santa Cruz (UESC) com articulação da Coordenação de Desenvolvimento do Ensino Superior do Instituto Anísio Teixeira (IAT), da Superintendência de Desenvolvimento da Educação Básica (SUDEB) e das Universidades Estaduais. Tal curso foi financiado e criado pela Secretaria de Educação do Estado da Bahia, a fim de qualificar os professores de Educação Física na rede pública.

Dessa forma, o estudo de Bahia (2016) revelou informações interessantes e relevantes sobre a formação continuada e a prática pedagógica do professor de Educação Física na Educação Básica. Destacamos as percepções dos docentes participantes sobre formação continuada em exercício quanto:

a) Às barreiras para realização da formação que estão centradas nos fatores intrínsecos $(60 \%)$ - cansaço físico, falta de motivação, obrigações familiares, falta de tempo e de dinheiro, desmotivação com a profissão e excesso de trabalho. 
Enquanto os fatores extrínsecos (40\%) estão associados à falta de apoio da gestão do município e do estado, à falta de ofertas de cursos na região e à ausência de apoio da gestão da escola;

b) À contribuição do poder público ao acesso à formação, $77 \%$ dos professores estão insatisfeitos ou indiferentes com a situação, enquanto apenas $23 \%$ estão satisfeitos com o apoio do governo;

c) À contribuição da formação continuada para a vida dos docentes, bem como para as instituições de ensino, assim promovendo a melhoria na qualidade de ensino e no desenvolvimento profissional;

d) À influência e ao reconhecimento da formação continuada no repensar a prática pedagógica dos professores a partir de conceitos, práticas e novas metodologias de trabalho; na troca de experiência com seus pares; ampliação do conhecimento pedagógico diante da articulação entre a teoria e a prática.

Por fim, Bahia (2016) aponta em suas considerações finais que as ações de formação continuada em exercício contribuem para o desenvolvimento da carreira docente, quanto aos aspectos pessoais e profissionais, além de auxiliarem de forma significativa em suas práticas pedagógicas. No entanto, salienta a necessidade de o professor reconhecer a importância desse processo ao longo da sua vida profissional.

Em virtude desses achados de Bahia (2016) sobre a contribuição da formação continuada no desenvolvimento profissional do professor, especialmente para a prática pedagógica, justifica-se a discussão desse trabalho no relatório de tese. Ao identificar o impacto provocado na atuação dos professores de Educação Física da Educação Básica, considera-se que a formação continuada também contribuirá nesses aspectos aos docentes do Ensino Superior, conforme a realidade inserida.

O estudo de Cruz Junior (2010) também contribuiu nessas modalidades de formação continuada discutida nesse subitem, pois o autor revela que as produções na área da Educação Física discutem, em sua maioria, sobre: formação continuada em serviço vinculada a cursos/grupos de estudo; formação continuada relacionada à pesquisa como formação/pesquisa-ação; capacitação/qualificação/formação “crítico-reflexiva" necessária à resolução de problemas oriundos da prática pedagógica ou vinculados a sua mudança; práticas de formação de responsabilidade institucional e pessoal; e atualização/ capacitação mediante a insuficiência da formação inicial. Como não é objetivo deste relatório descrever na íntegra os trabalhos investigados por Cruz Junior (2010), optamos apenas por apontar 
informações relevantes e possíveis de correlação com o objeto de estudo: prática pedagógica de professores de Educação Física atuantes no Ensino Superior jovens doutores.

O autor, ao analisar 18 artigos sobre a formação continuada nos periódicos da Educação Física, percebe que essa formação é visada como complemento da formação inicial, devido aos deficits, além de preparação para concurso público. No entanto apontam a necessidade e influência para a prática pedagógica dos professores, mas devem estar fundamentadas numa prática reflexiva ou crítico-reflexiva. Os estudos consideram que os modelos formativos fundamentados nas técnicas-instrumentais e nos eventos pontuais distanciam a teoria da prática, além de não compreender na íntegra os problemas do cotidiano do professor. Ainda ressalvam que a prática pedagógica consiste no aspecto basilar da proposta da formação continuada, a partir da qual emergem os problemas, provocações e situações que levam à reflexão e transformação.

Sabemos que as ações políticas de formação continuada aumentaram nas últimas décadas, pois vislumbravam a universalização do ensino, a necessidade da ampliação do quadro docente e a melhora do desempenho profissional, isto é, aperfeiçoaram a frágil prática pedagógica dos professores adquirida na formação inicial (DAVIS et al., 2012). A importância da formação continuada, entretanto, ultrapassa essas perspectivas políticas, pois é necessário entendê-la:

[...] a formação continuada como um processo que salienta a tarefa de oferecer aos professores oportunidades de desenvolvimento profissional e, em especial, no plano pessoal - independentemente de esse desenvolvimento ser definido pelos próprios docentes ou por especialistas contratados pelos sistemas educacionais $-\mathrm{e}$, ainda, de conferir a esse processo um caráter mais estruturado ou mais informal (DAVIS et al., 2012, p. 15).

Por fim, este capítulo sobre a profissão de Educação Física e as discussões sobre suas formações, seja inicial e continuada, procurou retratar o cenário vivido pelo profissional dessa área, além de aproximar a realidade vivenciada pelos professores jovens doutores investigados, pois antes mesmo de se tornarem docentes de Ensino Superior formam-se profissionais de Educação Física com habilitação para docência na Educação Básica e demais contextos de atuação dessa profissão. Ao realizar esse retrospecto formativo é possível compreender com mais propriedade os aspectos que compõem o desenvolvimento profissional desses professores, enquanto profissionais de Educação Física e docentes formadores. 


\section{CAPÍTULO 3 \\ CONSTRUÇÃO DAS IDENTIDADES DOS PROFESSORES UNIVERSITÁRIOS}

Neste estudo consideramos que a construção das identidades dos professores está imbricada de forma efetiva na sua prática docente. Em virtude disso, discutiremos sobre a concepção de identidade pautada em Erving Goffman e Claude Dubar, em seguida apontaremos estudos que abordam a temática sobre professores de Educação Física e docentes universitários.

As discussões que abordam a construção das identidades dos professores apresentam duas perspectivas teóricas, a da Psicologia e da Sociologia. Neste estudo abordaremos a segunda, a qual apresenta uma concepção interacionista, compreendendo a identidade como produto da socialização. Tal perspectiva condiz com as discussões de Goffman e Dubar como de Strauss, Berger e Luckmann, entretanto cada autor apresenta aproximações e distanciamentos em suas concepções sobre o assunto e principalmente as divergências epistemológicas nos afastam de outros autores e a possibilitam utilizar como base teórica Goffman e Dubar.

A interação consiste no meio condutor dos autores Goffman e Strauss. Ao longo da rotina diária as pessoas estão dispostas às relações sociais com outras pessoas e dentro desse ambiente lhes categorizam e criam atributos. Assim podendo ser "status social", bem como “identidade social", vejamos o exemplo de quando alguém nos apresenta a um estranho: "Esse é o Professor João, o qual possui um projeto de extensão com crianças com câncer, muito interessante!”. Entretanto nem sempre isso ocorre de forma positiva ao colocar como um atributo de ocupação, associando-o a um trabalho de grande valia junto à sociedade e de respeito (GOFFMAN, 1988).

Nessa perspectiva, Goffman (1988) compreende que a identidade social pode ser denominada virtual e real, a primeira está relacionada a como definimos o outro e a segunda consiste no que a pessoa demonstra ser por suas ações. Para o autor, quando é realizada essa categorização apontando os atributos, podemos julgá-la e rotulá-la, consolidando um estigma: “[...] usado em referência a um atributo profundamente depreciativo, mas que é preciso, na realidade, é uma linguagem de relações e não de atributos [...] um estigma é, então, um tipo especial de relação entre o atributo e estereótipo" (GOFFMAN, 1988, p. 07)

Há possibilidade de identificar três tipos de estigmas: a) abominações do corpo, associados às deformidades físicas; b) a culpas de caráter individual, relacionado à fraqueza, desonestidade, desemprego; homossexualidade etc.; c) tribais de raça, nação e religião, 
podendo ocorrer a partir da família e comunidade, passando de gerações a gerações (GOFFMAN, 1988).

Nesta contextualização sobre estigma, podemos identificar que a profissão docente, bem como, em específico o profissional de Educação Física, tem recebido estigmas nas últimas décadas, esse constructo social tem gerado o descrédito e a diminuição de interessados em ingressar nessas profissões. Atualmente, ocorreu uma alteração conceitual nos estigmas com o surgimento de outros, entretanto, em diversos espaços sociais, observamos o descrédito com relação a esses profissionais.

[...] poderia haver uma discrepância entre a identidade virtual e a identidade real de um indivíduo. Quando conhecida ou manifestada, essa discrepância estraga sua identidade social; ela tem como efeito afastar o indivíduo da sociedade e de si mesmo de tal modo que ele acaba por ser uma pessoa desacreditada frente a um mundo não receptivo (GOFFMAN, 1988, p. 20).

Apesar de o autor centralizar suas ideias e exemplos em pessoas com deficiência, homossexualidade, dentre outras situações sociais mais vulneráveis, podemos construir aproximações, com o professor e o profissional de Educação Física, sua teoria nos auxilia a compreender esse processo de estigmatização presente de forma efetiva na vida destes profissionais.

O autor menciona a discrepância existente entre a identidade virtual e real, dentro do contexto profissional, verificamos que tal situação possibilita a baixa procura nos cursos de formação, os quais necessitam que os órgãos responsáveis promovam incentivos à criação de cursos de Licenciatura e fomento a bolsas de estudos para que haja estudantes. Ainda consideramos que o espaço de trabalho inadequado e as baixas condições salariais disseminadas dentro da sociedade favorecem para a instabilidade da identidade social desses profissionais.

Assim compreendemos que a representação social desses profissionais interfere para essa discrepância existente entre sua identidade virtual e real. A Educação Física apresenta uma concepção junto à sociedade descontextualizada do que realmente ela representa no século XXI e isso resulta do processo histórico. Como mencionamos no capítulo 2, a formação desses profissionais está enraizada na concepção militarista, voltada ao corpo forte e preocupada com o desempenho físico. Ao longo do tempo as abordagens teóricas foram mostrando diferentes perspectivas sobre a profissão, bem como sua importância em diferentes espaços na sociedade: escola, clubes, clínicas, academias, dentre outros espaços. 
Independente dessas mudanças, a sociedade ainda apresenta um conhecimento empírico sobre a profissão, enxergando-a como uma atuação meramente prática, desprovida de um conhecimento teórico, além disso estigmatizam o profissional que é provido de um corpo físico magro e forte. Tal concepção está intrínseca nas pessoas, e acabam não percebendo que ainda apresentam esse posicionamento quanto aos profissionais, por exemplo: em uma escola a dispensa do professor de Educação Física da reunião pedagógica; quando um docente se ausenta na escola, colocam os alunos nas aulas de Educação Física; quando o estudante parece com nota baixa na disciplina de Educação Física ou acaba reprovando, os pais e a própria gestão vão questionar o professor - Como, em Educação Física? Raros são os pais/mães que vão à reunião perguntar como seu filho está se desenvolvendo nas aulas de Educação Física; se o professor engorda, desacreditam em sua prática profissional - como um professor de Educação Física com sobrepeso pode passar alguma atividade física? - Podemos ficar mencionando diferentes exemplos presentes e vivenciados no ambiente escolar, por nós professores de Educação Física.

Também é possível identificar em outros ambientes, os treinadores esportivos, em sua maioria, são ex-atletas da modalidade em que atuam; nos postos de saúde, quem faz o alongamento e orientação de atividade física são os enfermeiros, médicos e fisioterapeutas; ex-bailarinos atuam como professores de dança; ex-atletas atuam como professores em escolinhas esportivas. Isto é, aquela pessoa que praticou determinada atividade física e esporte regularmente por muito tempo se julga apta para desenvolver a função do profissional de Educação Física ou aquele profissional que estudou na área da saúde por quatro ou cinco anos se considera competente para prescrição de exercício.

É evidente que a demanda de pesquisa enfatizando a importância da prática de atividade física regular para um estilo de vida saudável é considerado o principal meio de prevenção de doenças. Apesar desse reconhecimento, há uma contradição nas ações das pessoas, mas passam despercebidas devido à importância atribuída por essa prática, a qual, antigamente, não era vista dessa forma.

O estudo de Mendes (2010), com profissionais de Educação Física que atuam em academias, aponta que o reconhecimento social varia entre ótimo $(n=15)$, bom $(n=25)$, regular $(n=11)$ e insuficiente $(n=1)$. Enquanto o da direção do estabelecimento que trabalha o reconhecimento ficou distribuído entre ótimo a péssimo, destacando a maior quantidade no bom $(n=17)$ e regular $(n=14)$. Entre os alunos predominou ótimo $(n=24)$ e bom $(n=25)$. Ao analisarmos a investigação de Mendes (2010), há um reconhecimento social relevante perante o profissional, mas a relação às condições de trabalho relacionado ao reconhecimento 
da direção e à satisfação com a renda apresentam lacunas na percepção dos profissionais de Educação Física que atuam na área da atividade física e da saúde.

No entanto há uma percepção diferenciada quando discutimos sobre a questão do reconhecimento do profissional de Educação Física atuante nas escolas. O discurso de um dos professores investigados por Moura (2015) revela que a valorização familiar e de amigos apareceu quando iniciou a atuar na área de musculação, quando começaram a perguntar sobre assuntos relacionados: alimentação, atividade física, doença etc. E outra professora aponta que seus alunos a associam com a função de médico, pois conhece sobre o corpo.

O estudo de Melo et al. (2018) discute sobre os estereótipos aplicados aos estudantes de profissionais de Educação Física, conforme a perspectiva de 117 universitários das áreas de ciências biológicas, exatas e humanas de uma instituição do Distrito Federal. A investigação revela que pontos positivos estiveram relacionados aos atributos físicos e emocionais como: forte, atlético, bonito, bem-humorado, divertido, dinâmico e amigo. Em contrapartida, quanto aos aspectos profissionais e sociais, encontraram-se inferências negativas como: pouco estudioso, desleixado, bagunceiro, burro, fedido e bombado. Os resultados encontrados preocuparam os investigadores, os quais enfatizam a necessidade de os estudantes e profissionais procurarem mudar essa perspectiva, pois isso apresenta um impacto negativo para a imagem desse grupo social.

Há uma outra discussão, também, que vem ao encontro desse enfraquecimento da área, é a questão da dificuldade de encontrar a identidade epistemológica da Educação Física. Tal problemática está associada a múltiplas subáreas sem alcançar um denominador comum, assim surgindo diferentes especialistas: fisiologistas, psicologia do esporte, dentre outros, mas poucos se enquadram em Educação Física, muito menos a preocupação na prática pedagógica. Tais situações dificultam sua compreensão como ciência, pois não apresentam atributos necessários para essa definição, consequentemente, levam a uma crise epistemológica da área (VARGAS; MOREIRA, 2012).

\footnotetext{
Além da crise de identidade epistemológica da EF, que tanto afeta a identidade profissional do docente, cabe ressaltar a crise que o atinge em decorrência das transformações pelas quais tem passado o processo de construção das identidades pessoais e sociais, no qual os sujeitos assumem identidades diferentes em distintos momentos, identidades que não se unificam, necessariamente, em torno de um eu coerente (VARGAS; MOREIRA, 2012, p. 414).
}

Há uma perspectiva diferenciada entre o profissional de Educação Física atuante no ambiente escolar e fora dele. Não se trata de clichê, essas afirmações estão intrínsecas no 
discurso e nas ações diárias das pessoas, se não for realizada uma análise crítica sobre tal atitude, acaba passando despercebida e isso influencia na construção da identidade profissional de Educação Física. Dessa forma corroboramos a perspectiva de Vargas e Moreira (2012).

Aos estudar sobre a identidade profissional de professores de Educação Física, Moura (2015) realizou um estudo da arte sobre essa temática, revelando que há uma disputa pela definição de uma identidade profissional no campo da Educação Física causada por diferentes campos de atuação; o currículo da formação inicial e da escola básica, bem como as práticas docentes da Educação Física, as quais ainda estão pautadas em concepções tradicionalistas. Tal cenário enfraquece a identidade profissional da Educação Física.

É evidente que há uma estigmatização do professor de Educação Física perante a sociedade, principalmente perante a comunidade escolar. A pesquisa realizada por Rossi e Hunger (2013), com professores Educação Física atuantes em escola pública da rede estadual de São Paulo, revela o descaso dos alunos e famílias com os docentes, enfatizando que essa situação piora com o passar do tempo. Os autores também apontam que a gestão escolar está preocupada com o aprendizado de matemática e português, assim contribuindo para a formação continuada dos professores que atuam nessas áreas, isso, em contrapartida, ofusca a formação dos professores de Educação Física.

Há privilégio de outras disciplinas em detrimento da Educação Física, cuja luta é constante pela permanência e ressignificação da identidade da Educação Física escolar e da identidade do professor enquanto profissional. Além disso, os docentes precisam sempre justificar a existência da disciplina no currículo a partir de diferentes aspectos: valorização da área, da reprovação; da pertinência para a atuação profissional futura e da disponibilidade dos professores no espaço escolar (MOURA, 2015).

À Educação Física cabe o desafio de superar os equívocos históricos que foram construídos, principalmente, no contexto escolar (MOURA, 2015), os quais marcaram de forma significativa a identidade real e virtual do professor. Dessa forma resulta na subordinação dos profissionais de Educação Física por profissionais que pouco conhecem ou reconhecem a área no espaço escolar; a desvalorização financeira e desrespeito com a categoria profissional; e a contradição existente no discurso sobre a importância da Educação para a formação de uma sociedade e a desvalorização do profissional que contribui para o desenvolvimento dos cidadãos. 
Com o debate da situação contemporânea do professorado, que os professores estão imersos em discursos ambíguos e em processos contraditórios. Não obstante a existência de um movimento de profissionalização e desprofissionalização concomitante, atribui-se ao professor o papel principal no processo de transformação da sociedade. Porém, muitas das propostas atuais para a profissão docente não são coerentes com os discursos, projetando-se para o futuro o que não se consegue resolver no presente, deslocando o eixo dos problemas políticos para o campo pedagógico (além de mascarar a pobreza das práticas políticas com o excesso de discursos). O resultado é a crítica ao professor por não ser capaz de garantir na escola o que a sociedade não consegue fora dela, passando a ser responsabilizado, por toda parte, pela incapacidade da instituição em resolver os desafios da atualidade (ROSSI; HUNGER, 2010, p. 55-56).

A dúvida pela permanência na docência foi outro fator mencionado no estudo de Rossi e Hunger (2013) e de Moura (2015), que afeta a identidade profissional docente, pois os professores se questionam quanto à continuidade ou não na função. Dessa forma estão buscando outras áreas para atuação, como espaços fora da escola ou gestão escolar. Tal desejo está relacionado às questões das condições de trabalho, conforme apontam alguns relatos:

com o passar dos anos a coisa tá caindo [...]. Os alunos não têm mais respeito [...] não têm mais paciência [...] está difícil trabalhar, está muito difícil trabalhar [...] Algumas disciplinas, principalmente Português e Matemática, eu vejo lá eles trabalhando, eles tendo reunião em DE, eles tendo que fazer curso, mas nós da Educação Física, faz mais de três anos já que eu não participo de nenhuma (ROSSI; HUNGER, 2010, p. 50-52)

A investigação de Nascimento e Rodrigues (2018) discute sobre essas representações que fazem relação com as motivações de permanência ou desistência da docência. Primeiramente, as autoras, no período de 2006-2012, identificaram as seguintes informações quanto ao abandono da docência: a desvalorização da profissão, a visão de que o professor é um mero reprodutor de conhecimento; os baixos salários; péssimas condições de trabalho, isto é, a escassez de recursos; as mudanças na relação professor/ aluno; e as crises na identidade do profissional. Nesse estudo relatam que a desistência ocorre gradualmente ao longo da carreira.

Além disso, ao analisarem dois grupos de docentes da Educação Básica, as autoras identificaram que há uma relação significativa na permanência dos professores na docência com a perspectiva altruísta. Entretanto a desmotivação dos docentes está relacionada a questões da falta de reconhecimento da profissão perante a sociedade, à falta de condições para ensinar, formação aos professores inadequada, à falta de cooperação da família, que coloca o insucesso do aluno sobre os professores, dentre outros. 
Ao refletirmos sobre as informações encontradas no estudo de Nascimento e Rodrigues (2018), compreendemos que essas motivações altruístas que o professor possui, associada ao dom, missão, dar sem receber etc., estão relacionadas à identidade real do professor, como ele se enxerga. Entretanto a sociedade não parte dessa mesma perspectiva, resultando em uma identidade virtual estigmatizada a partir da desvalorização profissional, baixos investimentos e o descrédito.

A construção de identidade virtual é possível identificar antes mesmo de tornar-se professor. O estudo de Lima (2016) constatou que a identidade de si construída pelos estudantes de pedagogia está o relacionada de forma positiva à profissão, principalmente pela importância da função do professor junto à escola e ao desenvolvimento de crianças e adolescentes. No entanto apontam que a identidade para o outro - sociedade - está associada à melhoria da qualidade de ensino, cobranças aos trabalhos desenvolvidos e à desvalorização da profissão. Assim, a autora considera que a identidade de si e a identidade para outros são fatores determinantes para a construção da identidade docente. Certamente, essa realidade não está distante dos estudantes dos cursos de Educação Física.

Ao se referir sobre identidade social, Dubar (2005) busca articular esses processos apontados por Goffman (1988) - identidade social virtual e real - entretanto denomina-a como processos relacional e biográfico. O primeiro está associado à identidade para o outro, ocorrendo uma transação objetiva. Corresponde à atribuição da identidade pelas instituições e agentes que estão socialmente ligados aos indivíduos, conforme Goffman (1988) define: rotulagem a fim de identificar o sujeito. Já o segundo condiz com a deliberação subjetiva sobre a rotulagem determinada, relacionada à autoidentificação. Dessa forma pode ser compreendido como transação subjetiva, na qual ocorre a transação entre as identidades herdadas e visadas. Compreendemos como incorporação da identidade pelo próprio indivíduo, sendo analisada apenas pela sua trajetória social vivenciada. O quadro 7 aponta detalhadamente as categorias de análise da identidade de acordo com Dubar (2005).

Quadro 7 - Categorias de análise da identidade

\begin{tabular}{|c|c|}
\hline PROCESSO RELACIONAL & PROCESSO BIOGRÁFICO \\
\hline Identidade para o outro & Identidade para si \\
\hline $\begin{array}{c}\text { Atos de atribuição } \\
\text { ("Que tipo de homem ou de mulher você é?" = dizem } \\
\text { que você é) }\end{array}$ & $\begin{array}{c}\text { Atos de pertencimento } \\
\text { ("Que tipo de homem ou de mulher você quer ser" } \\
\text { você diz que você é) }\end{array}$ \\
\hline $\begin{array}{c}\text { Identidade - numérica (nome atribuído) - } \\
\text { genérica (gênero atribuído) }\end{array}$ & $\begin{array}{c}\text { Identidade predicativa de Si } \\
\text { (pertencimento reivindicado) }\end{array}$ \\
\hline Identidade social "virtual" & Identidade social "real" \\
\hline Transação objetiva entre & Transação subjetiva entre \\
\hline
\end{tabular}




\begin{tabular}{|c|c|}
\hline $\begin{array}{c}\text { - identidades atribuídas/propostas } \\
\text { - identidades assumidas/incorporadas }\end{array}$ & $\begin{array}{c}\text { - identidades herdadas } \\
\text { - identidades visadas }\end{array}$ \\
\hline $\begin{array}{c}\text { Alternativa entre } \\
\text { - cooperação - reconhecimento } \\
\text { - conflitos - não-reconhecimento }\end{array}$ & $\begin{array}{c}\text { - Alternativa entre } \\
\text { - Continuidades - reprodução } \\
\text { - Rupturas - produção }\end{array}$ \\
\hline "Experiência relacional e social do PODER" & $\begin{array}{c}\text { "Experiência de estratificações } \\
\text { discriminações e desigualdades sociais" }\end{array}$ \\
\hline $\begin{array}{c}\text { Identificação com instituições consideradas } \\
\text { estruturantes ou legítimas }\end{array}$ & $\begin{array}{c}\text { Identificação com categorias consideradas } \\
\text { atraentes ou protetoras }\end{array}$ \\
\hline \multicolumn{2}{|c|}{ Identidade social marcada pela dualidade } \\
\hline
\end{tabular}

Fonte: Adaptado de Dubar (2005, p. 142)

O desacordo existente entre a identidade de si dos professores de Educação Física e a identidade atribuída pela comunidade em geral pode ser compreendida com a contribuição de Dubar (2005). O autor nos revela que todos podemos ser identificados por outrem, mas em contrapartida obtemos o livre arbítrio de aceitar ou recusar essa identificação, e nos definirmos com outra. A identidade não é cunhada à revelia do indivíduo. Essa identificação se utiliza de categorias sociais (profissionais, denominações étnicas, designações oficiais de Estado dentre outros). A identidade para o outro define o tipo de homem ou mulher que se quer ser a partir de atos de atribuição e atos de pertencimento estão relacionados ao tipo de homem ou mulher que se almeja ser associado à identidade para si.

Como visto por Goffman (1988), pode haver uma discrepância entre a identidade real e virtual ou certo desacordo entre elas. Tal situação leva o sujeito a desacreditar de si e/ou afastar-se da sociedade. Nos casos relatados dos professores de Educação Física, os profissionais acabam migrando para outra área ou desvinculando-se de suas funções, deixando a preocupação pedagógica para o segundo plano e mais se preocupando consigo.

Pires et al. (2017) realizam uma revisão sistemática sobre a identidade docente dos professores de Educação Física e acabam considerando que as dificuldades encontradas na prática docente podem levar à crise de identidades. Ao se depararem com o espaço escolar, identificando sua cultura, limitações e dificuldades associadas à prática pedagógica e à relação com os seus pares e alunos, tudo isso possibilita ao professor a reflexão sobre suas identidades, levando-os a construí-las ou a (re)construí-las.

Dubar (2005), entretanto, aponta a existência de estratégias identitárias denominadas por: transação objetiva (externa) e subjetiva (interna), que visam diminuir o distanciamento entre as duas identidades. Considera suas articulações o elemento principal para o processo de construção da identidade social, pois a transação objetiva ocorre entre o sujeito e os outros significados, buscando colocar da identidade para si à identidade para outro. Quanto à 
transação subjetiva, o sujeito resguarda para si partes das identidades herdadas e daquelas identidades que busca construir no futuro (identidade visada). Assim compreendemos que, para que ocorra a transação interna, é necessária a relação com o outro, ocorrida na transação objetiva.

A dualidade que marca a identidade social está associada à relação inseparável da identidade para si e da identidade para o outro, as quais ainda estão ligadas de maneira problemática. O sujeito só poderá compreender sua identidade de si se obtiver uma relação com a identidade do outro e seu reconhecimento, pois precisa do olhar do outro. É importante salientar que a identidade é construída e precisa ser (re)construída a partir de uma incerteza, seja maior ou menor, e duradoura, seja mais ou menos, e jamais poderá ser dada ou imposta (DUBAR, 2005).

Alicerçados em Dubar (2005), apreendemos que a articulação entre a transação objetiva e a subjetiva possibilita a construção das identidades sociais, a qual está associada ao modo de reconhecimento das instituições legítimas e pelos seus agentes, que apresentam uma relação de proximidade com os sujeitos envolvidos quanto às identidades herdadas, aceitas ou recusadas pelos indivíduos e pelas identidades visadas, identidades precedentes ou em ruptura.

A construção das identidades se realiza, pois, na articulação entre os sistemas de ação que propõem identidades virtuais, e as "trajetórias vividas", no interior das quais se forjam as identidades "reais" às quais os indivíduos aderem. Ela pode ser analisada em termo tanto de continuidade entre identidade herdada e identidade visada como de ruptura implicando conversões subjetivas (DUBAR, 2005, p. 140141).

Além das fundamentações de Dubar (2005) e Goffman (1988) nos ajudarem a interpretar o processo de construção da identidade do professor de Educação Física e o desacordo existente entre a identidade "real" e a identidade "virtual", os autores nos deixam uma reflexão importante sobre a reconstrução das identidades sociais "reais": as categorizações influenciam o processo de construção das identidades para si, mas elas não podem determiná-la ou firmá-la. Além disso os indivíduos, ao longo de suas gerações, precisam contribuir para a reconstrução de suas identidades "reais" com base nas identidades sociais herdadas da geração anterior, das identidades virtuais (atribuídas a partir da socialização primária) e das identidades possíveis (desenvolvidas a partir da socialização secundária - profissionais). 
Embora Goffman (1988) não faça uma relação direta com o contexto profissional, proporciona-nos subsídios para apreender que o professor de Educação Física, antes de ser considerado um profissional, possui uma identidade herdada e construída ao longo de sua socialização primária. Assim compreendemos que, sobre as identidades social e profissional, o docente é construído por uma identidade pessoal e identidade do eu, as quais são indissociáveis.

O indivíduo utiliza-se dos aspectos da identidade social para construir sua identidade pessoal. Em consonância, a partir de sua memória, possibilita organizar e consolidar a informação que confere a sua identidade social. Essas identidades são consideradas fundamentos de interesse e definições a outras pessoas, as quais obtém relação com indivíduo estigmatizado. Enquanto a identidade do eu está relacionada à subjetividade e à reflexão sobre o que considera vivenciar, isto é, o sujeito elabora sua própria identidade a partir da identidade pessoal e social que outros apresentam de si, mas o sujeito tem total liberdade de relacionar o que lhe interessa (GOFFMAN, 1988). Dessa forma compreendemos a relação existente entre a construção das três identidades a partir do estigma, conforme elucidado na Figura 5.

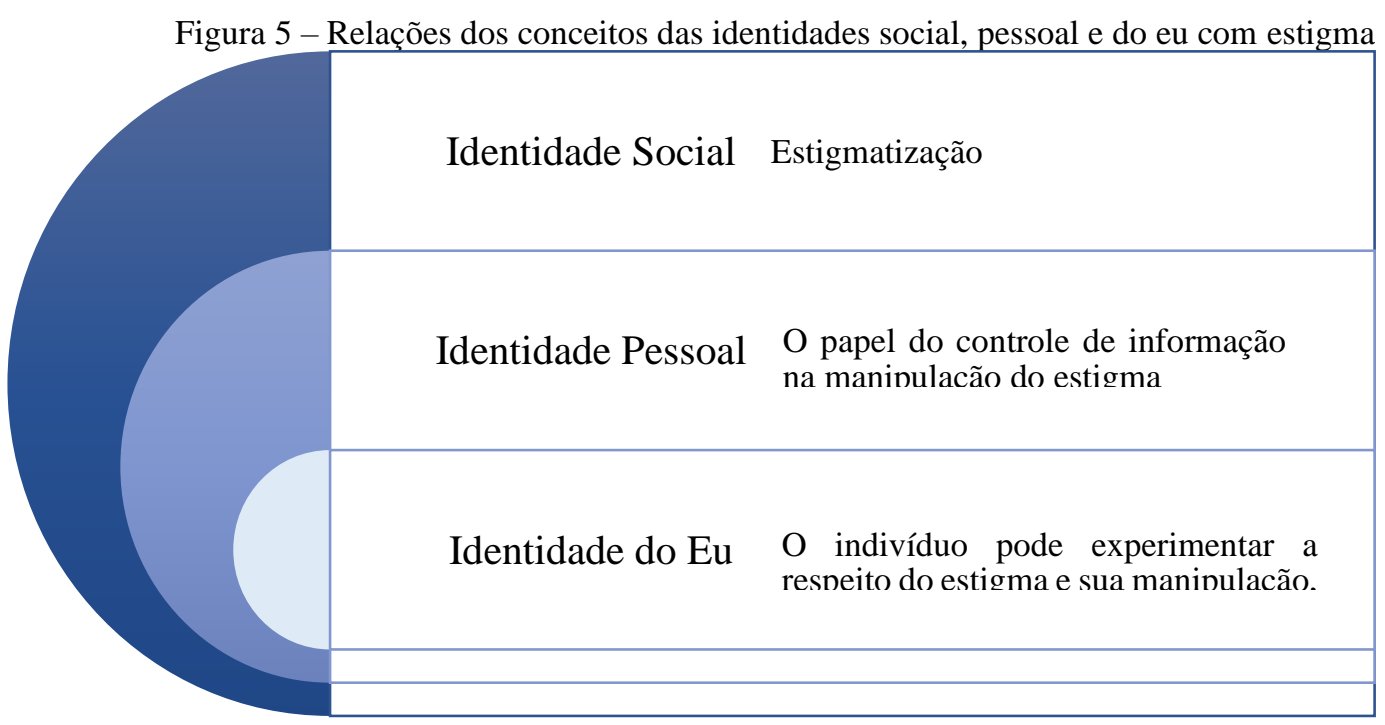

Fonte: Adaptado de Goffman (1988, p. 92)

As categorias sociais como emprego, trabalho e formação são contextos que nos permitem a identificação dos sujeitos, apesar de não serem as únicas, mas apresentam forte contribuição. O professor de Educação Física universitário, antes de torna-se pertencente a esse grupo profissional, fez parte de outros grupos, iniciando na infância, obtendo sua 
primeira identidade social. Tal identidade foi atribuída, inicialmente, pelos membros da comunidade escolar e a que convive não é escolhida por si (DUBAR, 2005).

Ao longo da trajetória da construção e (re)construção das identidades iniciada na infância, o sujeito dá continuidade a algumas marcas que lhe são atribuídas, mas também realiza rupturas, possibilitando algumas dúvidas quanto ao que foi adquirido ou construído. O momento marcante para a identidade social é a passagem da escola para o mercado de trabalho, considerado como ponto importante nessa constituição de uma identidade autônoma. No momento em que o sujeito escolhe por uma especialidade, proporciona a constituição de um ato de relevância para a identidade virtual (DUBAR, 2005).

É resultado dessa primeira confrontação que dependerão as modalidades de construção de uma identidade "profissional" básica que constitua não somente uma identidade no trabalho mas também e sobretudo uma projeção de si no futuro, a antecipação de uma trajetória de emprego e a elaboração de uma lógica de aprendizagem, ou melhor, de formação (DUBAR, 2005, p. 149).

Essa transição também está imbricada no processo de escolha profissional e podemos compreendê-la e inter-relacioná-la com a formação e inserção no mundo do trabalho, tal decisão está associada aos aspectos sociais, mas também ao contexto histórico e ao ambiente sociocultural em que o sujeito vive. Ainda podemos ir além, trata-se de uma estratégia identitária pessoal, a qual permite ao sujeito avaliar suas capacidades, suas expectativas e desejos futuros (DUBAR, 2005). É nela que a subjetividade e a objetividade são constituídas a partir da construção da realidade sobre as coisas, mundo e suas relações. A primeira está associada à história de vida do sujeito, enquanto a segunda apresenta uma interferência externa e do coletivo, a qual é fundamentada no contexto histórico e social inserido (NASCIMENTO; RODRIGUES, 2018).

O professor de Educação Física universitário pode almejar à docência universitária ao sair do Ensino Médio ou quando estiver no processo de escolha de uma formação profissional, mas precisa se especializar. Logo, antes de apresentar esse status social necessita obter uma formação inicial e pós-graduação para que isso se concretize. Ainda assim a identidade do professor do Ensino Superior é considera fragilizada, pois, normalmente, a escolha pela sua especialidade não está associada à formação de profissionais (ISAIA; BOLZAN, 2009). Em virtude disso, justifica-se a discussão inicial sobre o profissional de Educação Física para que assim possamos compreender o processo de construção das identidades de seus professores universitários. 
Prosseguindo a reflexão sobre o processo de escolha profissional pela Educação Física, está relacionada a socialização primária, a qual contribui para a construção de suas identidades sociais. A identificação e/ou a prática esportiva são os motivos mais citados ao longo das pesquisas, seja por profissionais atuantes em escolas (FOLLE; NASCIMENTO, 2008; HENRIQUE; COSTA, 2016; MOURA, 2015); clubes (RODRIGUES, 2014; OLIVEIRA, 2017; BORGES, 2018), universidades (VARGAS; MOREIRA, 2011; BASEI, 2011; 2012; MOLETTA, 2013) e estudantes que estão cursando Educação Física (RAZEIRA et al., 2014; SANTOS; SIMÕES; MOREIRA, 2018).

O estudo de Folle e Nascimento (2008) retrata investigações realizadas entre 19972007, que abordam o desenvolvimento profissional, o qual encontrou 65 produções científicas, nacionais e internacionais. Foram identificadas 27 que abordam a escolha profissional dos professores, predominando por motivos intrínsecos e altruístas: dom, vocação, a missão da docência, o gosto pela profissão, o desejo de ser professor e de trabalhar com crianças e jovens, ser um trabalho respeitado e com tarefas desafiadoras, poder contribuir com a sociedade. Enquanto a motivação extrínseca esteve relacionada à obtenção de recursos imediatos, influência de familiares e de amigos, segurança no trabalho, férias e horários flexíveis, facilidade de trabalho, dentre outros.

Esses autores, ao analisarem a escolha pela docência na Educação Física, verificaram que esta se assemelha aos dos professores das outras disciplinas, como: o gosto pelo trabalho com crianças e adolescentes, dom e vocação, desejo de ser professor e influência de outras pessoas. Entretanto apresentaram especificações nos motivos intrínsecos e altruístas ao associarem o amor ao esporte e pela atividade física e a identificação com a disciplina em si (FOLLE; NASCIMENTO, 2008). A influência de familiares, amigos e/ou profissionais de Educação Física de referências também foram fatores motivacionais para a escolha profissional (FOLLE; NASCIMENTO 2008; VARGAS; MOREIRA, 2011; MOLETTA, 2013; RAZEIRA et al., 2014; MOURA, 2015; HENRIQUE; COSTA, 2016; OLIVEIRA, 2017; BORGES, 2018).

Encontramos nas narrativas positivas dos estudantes e profissionais da área a influência do professor de Educação Física, assim compreendemos que, há uma incongruência de opiniões do cenário de desprestígio que a sociedade desenha sobre esse docente no espaço escolar. As práticas atrativas ao longo de suas aulas proporcionam uma perspectiva diferenciada sobre a profissão, o que leva seus estudantes a almejarem o trabalho desenvolvido por seus professores. Também foi identificada a influência dos treinadores esportivos, aqueles que desenvolviam atividade esportiva ao longo da sua infância e 
adolescência. Essa relação estabelecida com os professores de Educação Física e treinadores são fundamentais no processo de socialização primária do sujeito, pois utiliza-se das estratégias identitárias para construção da identidade para si, isto é, adquire sua identidade real, deixando de assumir a identidade atribuída pelo outro (identidade virtual).

A contribuição familiar nesse processo de escolha profissional está associada ao incentivo por sua opção formativa. Também foi revelado que a definição pela docência está relacionada à tradição e cultura da família com a docência. Compreendemos essa preferência pela prática profissional docente de geração em geração e a influência de profissionais de Educação Física quando Dubar (2005) associa as questões de incorporação da identidade com trajetória social vivida pelo sujeito.

Há outro fator associado ao contexto familiar que contribui para a inserção no trabalho, em contrapartida a busca pela carreira profissional condizente com a situação financeira. No estudo de Moura (2015), os professores de Educação Física investigados foram a primeira geração de sua família com formação superior, tal atitude foi condicionada à necessidade de mudança econômica e social. Além disso, os docentes possibilitaram o rompimento das ocupações manuais para intelectuais.

Os estudos de Vargas e Moreira (2011), Basei (2011; 2012) e Moletta (2013), com professores universitários de Educação Física, não diferem os fatores contribuintes da escolha pela formação inicial dos estudos com treinadores (OLIVEIRA, 2017; BORGES, 2018), docentes (FOLLE; NASCIMENTO, 2008; MOURA, 2015; HENRIQUE; COSTA, 2016) e estudantes de Educação Física (RAZEIRA et al., 2014; SANTOS; SIMÕES; MOREIRA, 2018) em virtude das experiências esportivas, identificação com a função e influência de pais e professores.

Quanto à escolha pela docência no Ensino Superior dos professores de Educação Física foram identificados três fatores relacionados: convite, identificação e influência. $\mathrm{O}$ primeiro fator esteve relacionado ao convite da coordenação do curso em que atua ou de colegas. No segundo os docentes atuantes na instituição pública esteve centrada na proximidade com pesquisa e na instituição privada esteve relacionado a função docente em si. Quanto ao aspecto influência, mencionado pelos professores da IES pública, esteve associado à motivação familiar e à contextualização vivenciada na graduação (MOLETTA, 2013).

No estudo de Basei (2012), a escolha profissional pela docência do Ensino Superior dos professores de Educação Física esteve centrada na melhoria de sua prática pedagógica na escola, buscando o mestrado que, consequentemente, leva à atuação na graduação. O outro 
fator mencionado foi a inquietação e o desgosto durante a formação inicial, assim eleva o interesse por fazer diferente na formação de profissionais de Educação Física. Outro professor relata que o interesse veio ao longo da graduação, como estava inserido na universidade, vislumbrou atuação como professor do Ensino Superior, por isso buscou formação para tal.

Na mesma perspectiva, Moura (2015) compreende que as discussões sobre a identidade profissional na área da Educação Física são recentes. Ao realizar uma pesquisa sobre o estado da arte em dissertações, teses e artigos do período de 2005 a 2012, encontrou apenas um estudo, em 2005, com temática em discussão, e apresentou dois momentos com oito obras, em 2010 e 2012 (o máximo encontrado por período). Os temas discutidos foram organizados em: formação profissional $(n=10)$, atuação e desenvolvimento profissional $(n=08)$, saberes docentes $(n=05)$, socialização profissional $(n=03)$ e autonomia docente $(n=01)$.

É evidente a predominância nas investigações referente à identidade docente sobre influência da formação inicial, dos currículos formadores, perfil do egresso e o significado da docência em Educação Física (PIRES et al., 2017). No entanto há poucos estudos que discutem sobre a identidade do professor de Educação Física da Educação Básica ao Ensino Superior, relacionando as contribuições das experiências de vida e sua importância para a construção identitária (MOURA, 2015; PIRES et al., 2017).

Como discutido no capítulo 1, sobre docência universitária, sabemos que, para atuação no Ensino Superior, é preciso obter formação inicial e pós-graduação, em sua maioria stricto sensu. Logo, a construção da identidade do professor universitário sobressai nos espaços de socialização em que o profissional de Educação Física atua, seja na escola e/ou em outros espaços, cuja exigência mínima é a graduação.

A identidade do docente do Ensino Superior é construída a partir da identidade de professor, profissional (nesse caso em discussão - Educação Física) e pesquisador. Entretanto, há uma relação distanciada da identidade de professor devido as experiências no campo da pesquisa e profissional, na qual está atrelada sua formação específica, pois os motivos que levam esses docentes a atuação no Ensino Superior são variados, e o ensino é o interesse de menor relevância (PIMENTA; ANASTASIOU, 2010).

No caso do professor de Educação Física que possui habilitação em Licenciatura, esse distanciamento com as questões pedagógicas existe, mas com lacunas menores, ao contrário dos profissionais com habilitação no Bacharelado. No primeiro caso, os aspectos pedagógicos são trabalhados desde a formação inicial, mesmo que o foco seja a Educação 
Básica, mas a identidade docente já se inicia, no entanto não apresentam propriedades das funções e objetivos do Ensino Superior. Já o egresso de Bacharelado terá aspectos restritos na graduação aos espaços de clubes, academias, clínicas dentre outros locais que poderá atuar e na pós-graduação, como discutido no capítulo 1, predomina na formação a pesquisa em detrimento da formação pedagógica.

\begin{abstract}
A identidade do professor de ensino superior, portanto, se dá nas interligações, no entrecruzar de redes e nos espaços de interlocução nos quais as trajetórias do indivíduo, o campo disciplinar formativo, as áreas de conhecimento, o trabalho profissional e suas práticas e os laços institucionais têm papel basilar (FRANCO; GENTIL, 2007, p. 46)
\end{abstract}

A construção biográfica da identidade profissional está vinculada às relações estabelecidas no trabalho, participação em atividades coletivas e intervir de alguma forma em representações. É a partir dessas relações que ocorrem as negociações identitárias, as quais levam à (re)construção da identidade profissional. Esse tipo de identidade é organizado em quatro modelos, os quais apresentam uma configuração específica que resulta de uma dupla transição: a) o indivíduo e a instituição; b) o indivíduo e o confronto de mudança do seu passado (DUBAR, 2005). As identidades são compreendidas como “[...] produtos de articulação entre uma identidade (virtual) atribuída pelo outro e uma identidade (virtual) para si construída ao longo da sua trajetória anterior" (DUBAR, 2005, p. 253). Tal situação advém a partir da socialização profissional e da identidade social (ALVES et al., 2007).

Os modelos denominados por Dubar (2005) são desenvolvidos em empresas, mas Alves et al. (2007) produzem um artigo, a fim de realizar uma fundamentação teórica sobre a construção da identidade profissional de professores, fazendo aproximações com a realidade docente e suas configurações identitárias. Compreendem-nas pelas transações objetiva e subjetiva, sendo a primeira a relação estabelecida do indivíduo com o ambiente de trabalho e as contribuições dessa função laboral para seu contexto social. A segunda consiste na relação temporal do indivíduo com a profissão, expectativas realizadas para si e identidade construída ao longo de sua trajetória de vida. Essa segunda transação o indivíduo pode identificá-la como uma transição contínua da identidade já existente, uma visão de si para o futuro ou ainda como uma ruptura da sua identidade (DUBAR, 2005; ALVES et al., 2007).

O primeiro modelo é nomeado "do distanciamento ao processo de exclusão: a identidade de executor "estável" ameaçada". Na figura 6 apresentamos esse modelo, a representação de Dubar (2005) ao discutir sobre operário e de Alves et al. (2007) ao abordarem sobre a configuração identitária dos professores. Dessa forma, verificamos que os 
profissionais que se enquadram nessa identidade de executor "estável" ameaçada apresentam no centro o trabalho, consideram que sua aprendizagem está relacionada com os saberes práticos. Embora os operários não estejam engajados à formação escolar, os professores não apresentam essa relação, em contrapartida, ambos deixam predominar suas experiências. A relação de dependência de superiores é significativa, caso ocorra alguma mudança ocorre uma instabilidade. A expectativa de progressão futura no trabalho não está presente nesse grupo de trabalhadores, operários e professores.

Figura 6 - Modelo do distanciamento ao processo de exclusão: a identidade de executor “estável” ameaçada do operário e do professor.

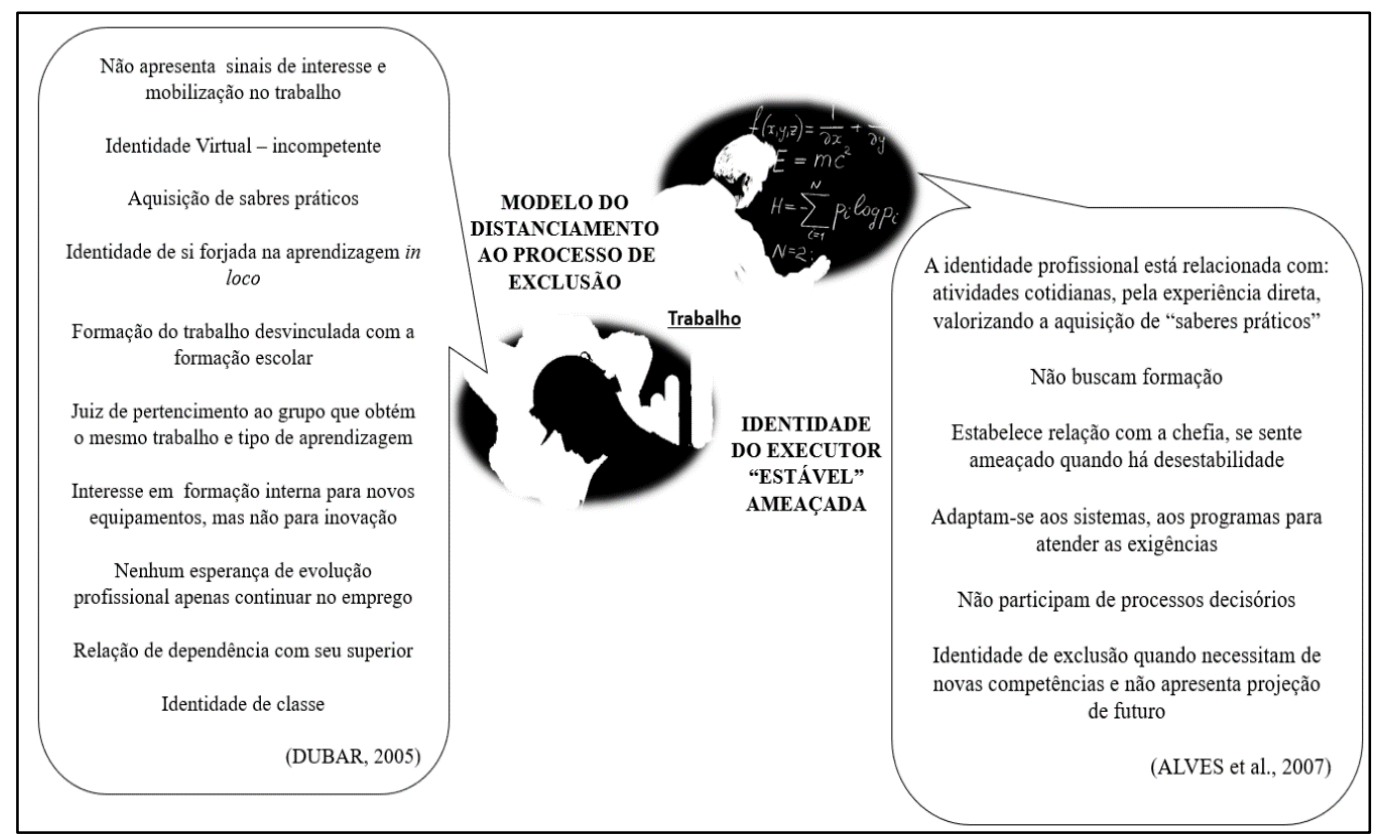

Fonte: Adaptado de Dubar (2005) e Alves et al. (2007)

No segundo modelo, titulado do operário por ofício ao "novo profissional": a identidade bloqueada apresenta a característica de um assalariado polivalente, preocupado em mostrar resultado, deixa de ser operário para se tornar operador, colaborador e, às vezes, técnico. Normalmente possui diploma, mas em formação técnica, a qual está ligada ao seu ofício e com projeção de carreira. Já aqueles que se identificam bloqueados quanto a sua situação profissional ou até mesmo com inquietudes quanto ao futuro, associam tal sentimento à organização do trabalho e da gestão do emprego e não vêm expectativa futura nas formas polivalentes que lhes são propostas. Além disso, não compreendem as causas das formações inovadoras e cursos desenvolvidos fora do ambiente de trabalho.

Esse contexto descrito sobre o bloqueio do assalariado, que é incorporado em sua identidade, pode provocar uma ruptura nos valores e crenças construídos a partir da sua formação. Há outra preocupação com outros jovens contratados com diplomas de formação 
elevada, os quais não apresentam sua identidade ofício, alicerçada em defender seu emprego e evitar qualquer estigmatização por parte dos superiores. O bloqueio pode ser compreendido a partir de uma relação problemática existente entre as duas transações que constituem a identidade:

\begin{abstract}
A transição subjetiva permanece positivamente orientada para a esperança de uma progressão futura: o assalariado permanece persuadido de ser capaz de ocupar um cargo mais qualificado, de recuperar e reatualizar os saberes técnicos adquiridos por ocasião de uma formação atual e contínua, de progredir dentro da empresa se oportunidades aparecerem em um estado futuro de situação [...]. A transação objetiva é totalmente dependente das políticas de gestão da empresa: estas não podem abstrair a pessoa mesmo que possam se apoiar apenas em poucas informações realmente utilizáveis e esclarecedoras (SAINSAULIEU, 1987, p. 325 apud DUBAR, 2005, p. 278).
\end{abstract}

A identidade do ofício parte da transação objetiva que possibilite ao assalariado a autoconfirmação regular da sua evolução, relacionada ao domínio progressivo de sua especialidade. Os interesses são saberes profissionais que alicerçam essa identidade, mas saberes relacionados a fatores operacionais e não científicos.

A configuração identitária dos docentes equivale à dos assalariados, quando se enxergam polivalentes. Os professores administram seu espaço de forma estruturada, mas sem mudanças, por isso perdem sua identidade própria quando apresentam o sentimento de cumpridor de programas, o que os tornam não realizados, ocorrido na transição subjetiva (Figura 7).

Figura 7 - Modelo do operário ao "novo profissional": a identidade bloqueada a partir operário e do professor

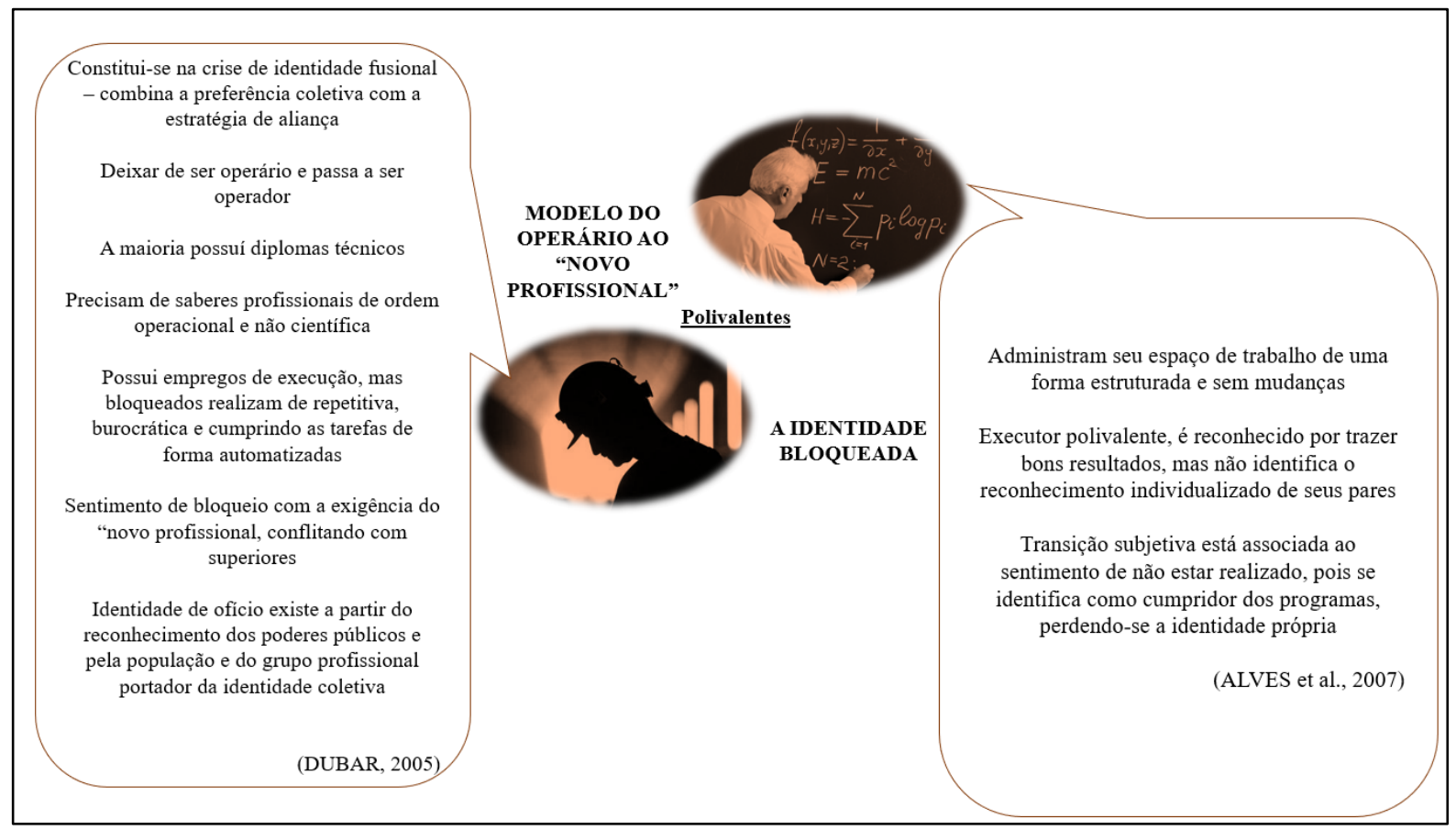

Fonte: Adaptado de Dubar (2005) e Alves et al. (2007) 
O terceiro modelo aborda o "carreirista" ao processo de mobilização: a identidade de responsável em promoção interna, o qual enfatiza a relação próxima da identidade do assalariado com a empresa. Podemos ainda dizer que sua identidade virtual é uma identidade de empresa, associada apenas ao projeto empresarial que potencializa sua identidade. Com o avanço da empresa, consequentemente também da sua identidade profissional e social, o assalariado vai (re)construindo sua identidade

Além disso, o assalariado apresenta uma identidade mobilizadora, pois busca se desenvolver junto com a empresa, dessa forma é nutrida pelas vivências em outros setores. Reconhece a importância da formação e é movido pelo interesse, assim particularizando sua identidade social real. O sentimento almejado de saber, conhecer mais, perguntar e compreender leva o assalariado ao ato de pertencimento à empresa. Seus saberes são considerados de organização, articulando os saberes teóricos e práticos. O primeiro é alcançado em aulas, conversas, documentos e autoformação e o segundo é adquirido in loco e pela experiência.

A transação subjetiva e objetiva são dinâmicas dentro da construção da identidade de empresa, pois o assalariado apresenta uma relação de colaboração com a empresa, resultando no reconhecimento de seus saberes, bem como em uma perspectiva futura profissional. A consolidação dessas transações ocorre juntas na construção da identidade quando acontece o reconhecimento pela empresa.

O interesse apresentado pelo assalariado e seu engajamento junto à empresa também se apresenta nos docentes, os quais associam o êxito da escola ao próprio feito e conquista. A relação com a instituição de ensino é significativa e proporciona ao professor o sentimento de pertencimento. Nesse contexto constrói sua identidade que se fortalece quando apresenta o sentimento de reconhecimento e crescimento na escola. O docente assume que seu desenvolvimento profissional está em ascensão, evitando a estagnação e a despreocupação com o pedagógico (Figura 8). 
Figura 8 - Do modelo "carreirista" ao processo de mobilização: a identidade de responsável em produção interna de operários e docentes.

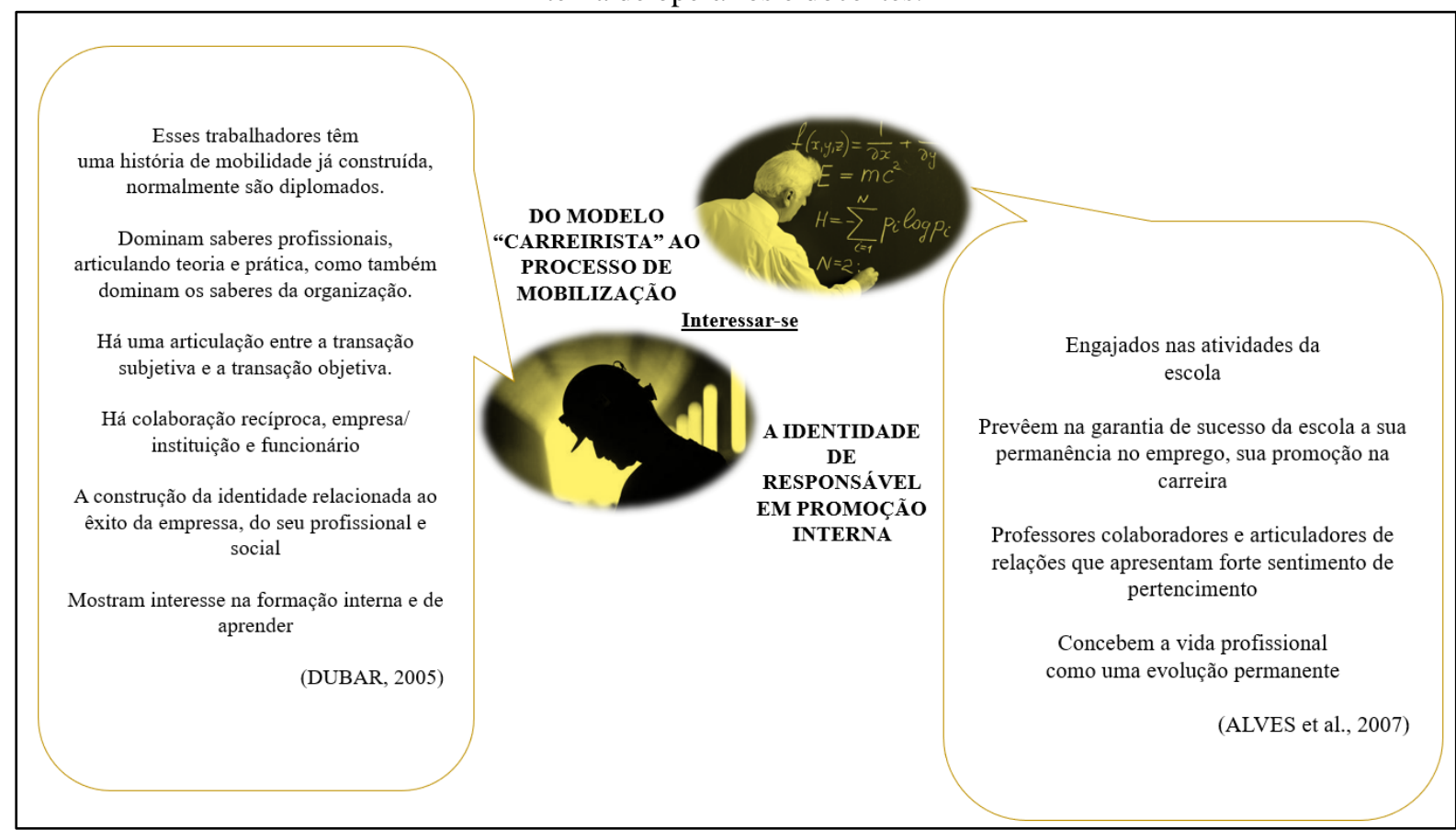

Fonte: Adaptado de Dubar (2005) e Alves et al. (2007)

O quarto e último refere-se ao "modelo afinitário" ao processo de recapacitação, os quais correspondem à identidade autônoma e incerta de assalariados que normalmente são jovens bacharéis. A identidade biográfica para si é marcada por sua formação, principalmente, referente ao diploma, identificando-o como investimento pessoal. Em virtude disso, sua preocupação está em formações externas de interesse para si do que ao trabalho desenvolvido. Em seu discurso predominam suas características formativas e projetos futuros, em contrapartida pouco menciona sobre a sua situação profissional. Então, a identidade para si está relacionada às atividades de formação e culturais, seu grupo de origem ainda permanece o grupo de referência.

Os assalariados que se enquadram nesse modelo apresentam em sua identidade relacional para si a marca do individualismo, pois não apresentam nenhum pertencimento ao grupo da empresa. Utilizam-se das oportunidades para inovações e benefícios próprios, isto é, se envolvem em iniciativas de mobilização a fim de alcançar seus objetivos pessoais. Os saberes que nutrem sua identidade estão relacionados aos saberes teóricos e culturais e não aos saberes práticos, de trabalho, profissionais construídos no ofício, dentre outros, compreendendo que sua identidade pode ser considerada instável e continuamente reconstruída. 
[...] identidade instável, móvel, dilacerada, que corresponde a uma dissociação duradoura entre a identidade para si (herdada de suas origens e projetada em um futuro inapreensível) e a identidade para o outro (atribuída com base na atividade profissional e nos status sociais oficiais). É uma identidade que combina a mobilidade com ausência (ou a recusa) de sustentação profissional ou organizacional (DUBAR, 2005, p. 316).

Alves et al. (2007) apontam que as características que configuram a identidade profissional do docente que se aproximam desse modelo condiz na valorização e no investimento de capacitações dentro e fora da escola, enquanto na descrição de Dubar (2005) os assalariados são críticos às formações internas, predominando as externas. Também não apresentam sentimento de pertencimento à instituição escolar de forma significativa, desde que isso alcance interesses próprios. Como os professores investem em sua formação, o que os move são os interesses pessoais, pois não apresentam laços com a escola e condicionados a tendências em seguir a carreira acadêmica (Figura 9).

Figura 9 - Do "modelo afinitário" ao processo de recapacitação: a identidade autônoma e incerta de assalariados e professores

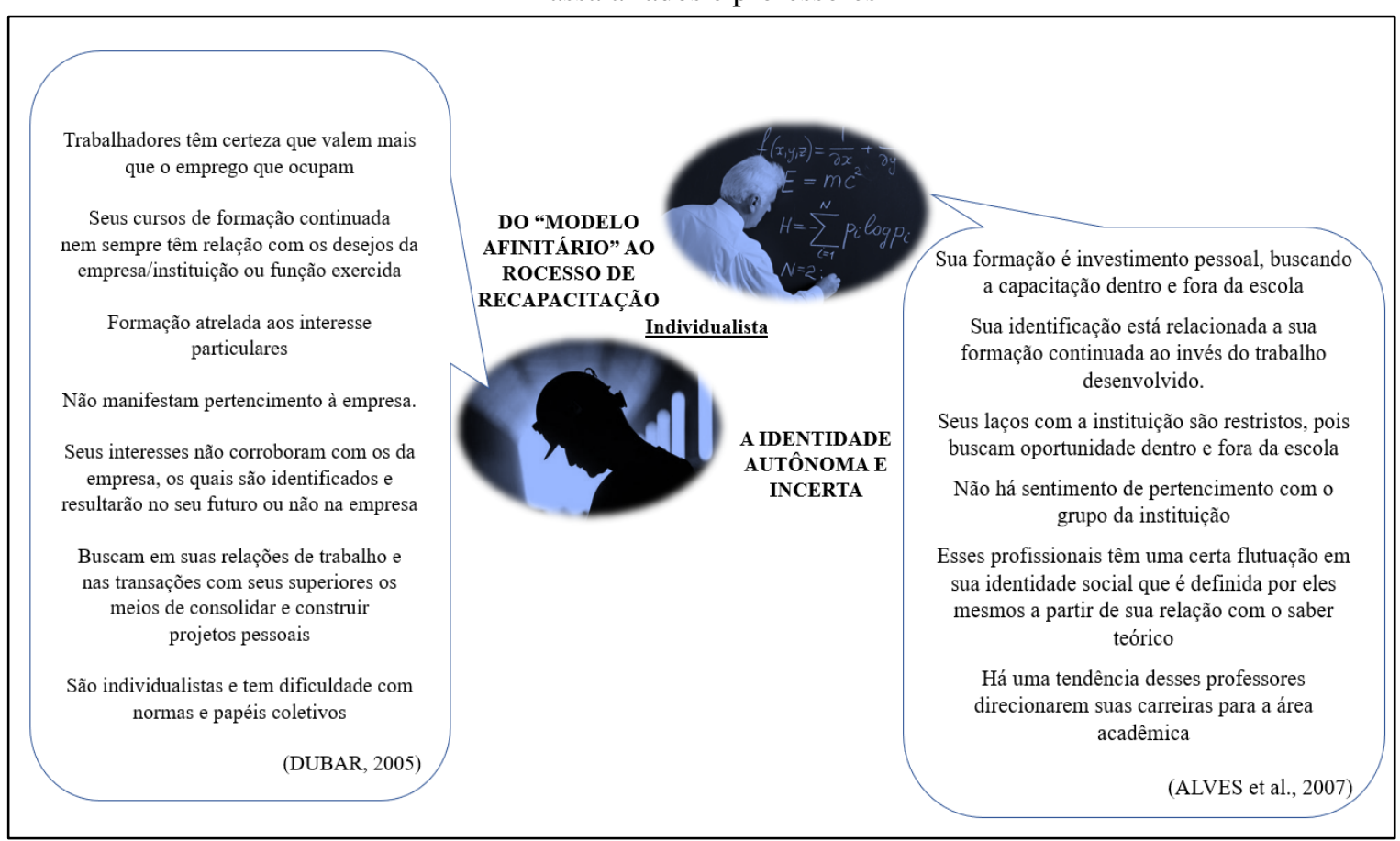

Fonte: Adaptado de Dubar (2005) e Alves et al. (2007)

Os quatros modelos apresentados estão alicerçados na questão socioprofissional, os quais contemplam as trajetórias sociais e se mobilizam a partir de categorias oficiais, posições em espaços escolares e socioprofissionais. As identidades são compreendidas a partir das articulações existentes entre as transações: a subjetiva (identidade herdada e visada) 
e objetiva (identidade atribuída para outrem e identidade incorporada para si) (DUBAR, 2005).

A construção da identidade profissional e social ocorre a partir dessas transações, as quais integram uma estrutura de continuidade ou ruptura (subjetiva), em ambas pode ocorrer reconhecimento social e não (objetiva). Em virtude disso, surgem quatro tipos de processos que configuram suas respectivas identidades: exclusão - identidade ameaçada; conversão identidade incerta; promoção - identidade de empresa; e bloqueio - identidade de ofício (DUBAR, 2005).

A construção da identidade ameaçada e incerta ocorre entre o espaço "interno" do trabalho, do emprego e da empresa e o espaço "externo" fora do trabalho, do desemprego ou da formação. Quanto às identidades de empresa e de bloqueio, são constituídas em um espaço único, no espaço organizacional da empresa ou espaço profissional do ofício (DUBAR, 2005).

Além do espaço, reconhecemos também que a identidade é construída no espaçotempo e, ao longo de suas configurações, identificamos que se constituem diferentes momentos que contemplam a biografia profissional ideal. O momento marcado de construção da identidade está relacionado à formação profissional inicial. $\mathrm{O}$ momento de consolidação é a inserção e aquisição progressiva nos planos de carreira profissionais. $\mathrm{O}$ momento de reconhecimento, o alcance da responsabilidade nas carreiras empresariais e o último momento condiz com o envelhecimento da identidade e o encaminhamento à aposentadoria (DUBAR, 2005).

Os saberes também estruturam a identidade, os quais foram reconhecidos em quatro tipos: saberes práticos advindos das experiências profissionais, sua lógica está relacionada ao salário com a preocupação em ter - identidade ameaçada de exclusão; saberes profissionais associam os saberes práticos e técnicos com a lógica do trabalho, isto é, de fazer - estruturada na identidade de ofício, passando para identidade bloqueada; saberes de organização fundamentados em saberes práticos e teóricos e sua lógica está atrelada à responsabilidade (ser) - identidade de empresa; saberes teóricos não constitui vínculo com os saberes práticos nem profissionais, apresenta a lógica de recapacitação permanente (saber) - identidade da incerteza e instabilidade.

Enfim, as identidades profissionais e sociais explicitadas são construídas a partir dos processos de socializações. A socialização primária ocorre a partir do contexto familiar e grupos de referências, os quais possibilitam as primeiras aquisições sobre os valores sociais, enquanto a socialização secundária está atribuída aos saberes profissionais, relações em 
campos especializados, podendo ser ou não resultado de uma identidade social autônoma. Além disso, pode dar continuidade à socialização primária, no entanto podem ocorrer rupturas, assim reconstruindo a identidade (DUBAR, 2005; PAGNEZ, 2007). "As identidades, portanto, estão em movimento, e essas dinâmicas de desestruturação/restruturação às vezes assume a aparência de uma "crise das identidades" (DUBAR, 2005, p. 330).

Tal crise pode advir de uma identidade que não se deseja ou a identidade almejada é recusada, isto é, o questionamento da relação de si mesmo com os outros e consigo mesmo (DUBAR, 2012). A estigmatização relatada por Goffman (1988) e a discrepância entre a identidade "real" e "virtual" estão diretamente ligadas à crise de identidades mencionada por Dubar (2005; 2012).

Os modelos que abordamos sobre Dubar (2005) e Alves et al. (2007) nos possibilitaram compreender a construção das identidades profissionais e sociais de operários assalariados e professores e, a fim de aproximar com a população investigada nesse estudo, que é o professor universitário de Educação Física, ainda vamos trazer mais quatro modelos propostos por Pagnez (2007), fundamentados em Dubar (2005), mas configurando a identidade dos docentes do Ensino Superior da área da saúde: pioneiro bloqueado, pioneiro crítico, convertidos resignados e convertidos transformadores (Figura 10).

Figura 10 - Modelos Profissionais Docentes atuantes no Ensino Superior na área da Saúde

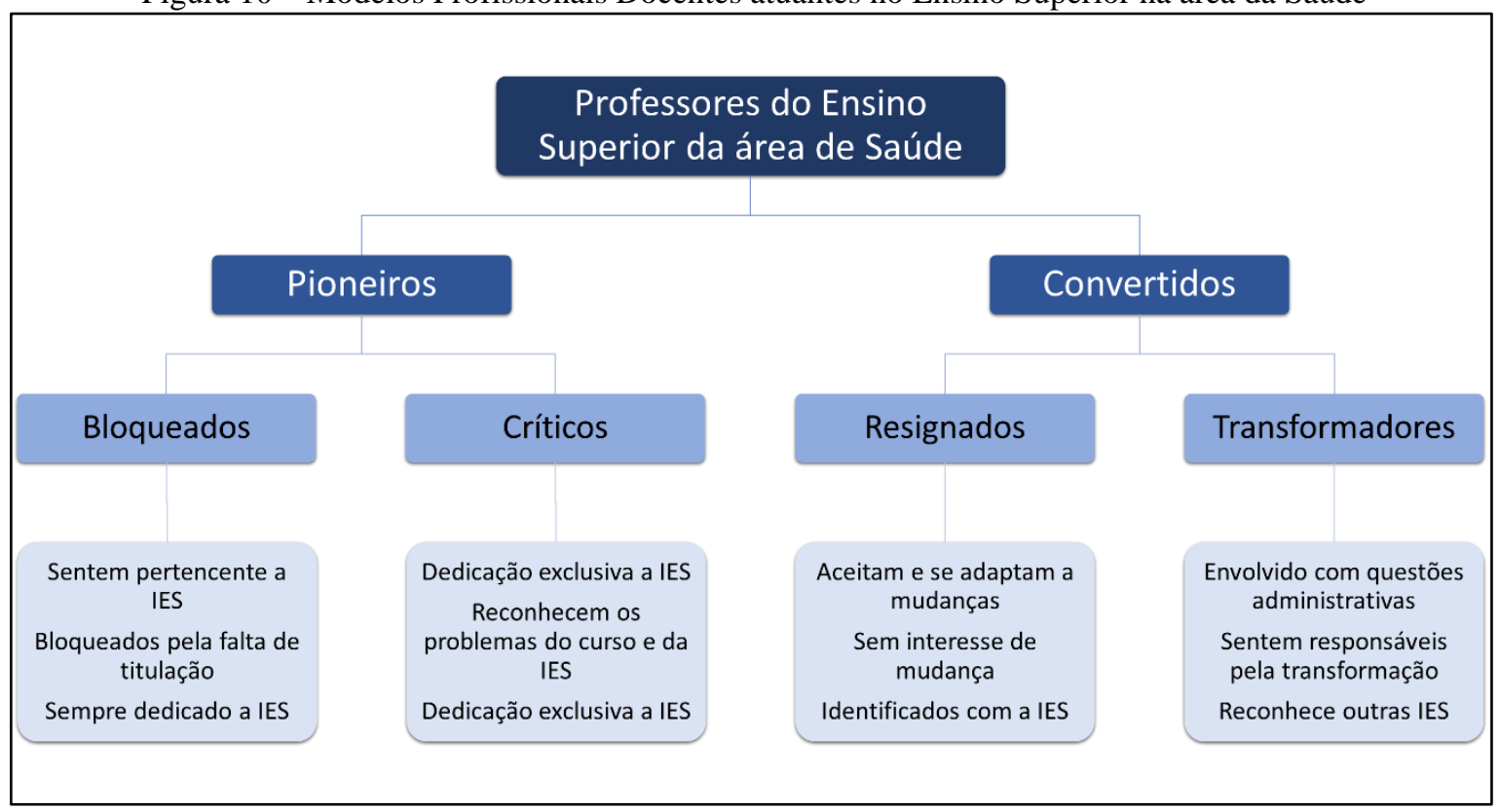

Fonte: Adaptado de Pagnez (2007) 
Os professores pioneiros foram caracterizados por ingressarem como docentes na instituição para constituição do curso, os quais já possuíam uma trajetória na docência. Por serem os precursores de seus cursos também os identificam como curso com diferencial na IES.

Além dessas descrições, os pioneiros bloqueados sentem-se pertencentes à IES, integram sua filosofia e apresentam uma trajetória longa na instituição. No entanto a falta de titulação bloqueia o desenvolvimento do professor dentro da IES e seu reconhecimento está associado ao respeito pelo profissional e suas contribuições. Esses professores estão na fase da aposentadoria, mas almejam novos caminhos para seguir.

Os pioneiros críticos apontam os problemas do curso, da IES e até da sociedade em si, sem restrições para tais observações, ainda não se eximem de suas responsabilidades nessas questões mencionadas sobre o contexto em que vivem. Também reconhecem que poderiam fazer mais pelo desenvolvimento da instituição e formação dos estudantes, mas se justificam que as novas regras os impedem. Possuem o regime contratual de dedicação exclusiva com a instituição, assim restringindo o espaço de atuação profissional.

Os docentes convertidos são formados pelos professores pioneiros, sua característica fundante está relacionada à transformação e mudança de forma. Sua transformação esteve relacionada pela atuação dos pioneiros quanto aos seus compromissos éticos, morais e filosóficos.

Os convertidos resignados reconhecem os problemas do curso e da instituição, mas não se enxergam fora desse espaço, pois aceitam as mudanças e conseguem se adaptar a elas. Consequentemente, não há interesse de mudar de IES, pois se identificam com a IES. Enquanto os convertidos transformadores são professores envolvidos em diferentes contextos dentro da instituição, assumindo funções de gestão e administrativa. Sentem-se responsáveis pelas transformações em seu espaço de trabalho, mas também reconhecem outras IES para o desenvolvimento da docência.

As fundamentações teóricas explicitadas até o momento (GOFFMAN, 1988; DUBAR, 2005; ALVES et al., 2007) irão contribuir para a compreensão das configurações identitárias dos professores de Educação Física jovens doutores. Conforme o estudo de Moletta (2013), com 21 docentes universitários com essa formação, os quais atuavam em diferentes eixos curriculares - dimensões - que constituem os cursos de Licenciatura e Bacharelado, foi possível identificar pontos congruentes aos modelos e configurações apontados por autores supracitados. 
Os professores universitários de Educação Física atuantes em uma universidade pública $(\mathrm{n}=10)$ e privada $(\mathrm{n}=11)$ do estado de Santa Catarina apresentam-se pertencentes a sua IES. O grupo de professores da universidade pública é o corpo docente com o qual nossos jovens doutores se depararam ao ingressar nessa IES. Os professores dos cursos de Licenciatura e Bacharelado dessa IES são divididos em dois grupos: os docentes que atuam na pós-graduação e os que atuam apenas na graduação. Tal situação ocorre devido à supervalorização do programa de pós-graduação em detrimento da graduação, levando os docentes a uma perspectiva corporativista sobre seus pares (MOLETTA, 2013).

Além disso, os docentes, em sua maioria, apresentaram uma postura individualizada e com disputa de poder, isso ocorre devido à falta de interlocução entre os docentes, divergências de opiniões propagadas de forma paciente e conflitante. Apesar dessas distinções de perspectivas e conflitos, o desejo do crescimento da instituição e melhoria do curso está fortemente presente entre os docentes, levando-os a uma cultura docente de colegiado artificial (MOLETTA, 2013).

Os problemas que contornam a universidade pública foram discutidos de forma concreta e confiante. Independentemente do caráter da IES, foi identificado que o desgosto dos professores teve maior concentração no excesso de burocracia em suas atividades e no sentimento de desvalorização docente (MOLETTA, 2013).

Esse cenário exposto pelos professores de Educação Física universitários da IES particular pode levá-los à exclusão e ao bloqueio, conduzindo a uma identidade ameaçada e à identidade de ofícios. Outro ponto de destaque que constitui a identidade profissional dos docentes universitários de Educação Física que corrobora os modelos sobre a questão são os métodos desenvolvidos a um longo período e as inovações. Nesse caso, os professores reconhecem as inovações e alguns deles buscam de forma gradativa inserir-se nas mudanças necessárias, a fim de desenvolverem sua prática pedagógica. Enquanto isso, outros professores reconhecem as inovações e sua importância, mas ainda continuam desenvolvendo práticas de cunho "tradicionalistas", isto é, o professor é o centro do conhecimento, predominando as aulas expositivas (MOLETTA, 2013).

A questão de hierarquia e dependência do assalariado com seus superiores também foi ponto que contribui na constituição da identidade. O corpo docente da IES pública, em sua maioria, apresentou uma relação de imparcialidade, restrita ao profissional gestor. Por ser uma instituição pública com dedicação exclusiva, os professores são mais autônomos, levando-os a um distanciamento das relações no ambiente de trabalho (MOLETTA, 2013). 
Apesar dos relatos sobre a desvalorização docente, os quais estão centrados nos recursos e questões financeiras, os professores mencionam estar satisfeitos com a instituição em que lecionam. Primeiramente pelo incentivo ao desenvolvimento e capacitação profissional e plano de carreira. Em seguida, os docentes se identificam com a missão da universidade quanto ao desenvolvimento na sociedade (MOLETTA, 2013). Esses compartilhamentos de desejos entre o corpo docente e a instituição é um fator que impulsiona a construção da identidade profissional e sua satisfação com o ambiente em que atuam.

A partir dessa descrição exposta, podemos compreender algumas configurações identitárias que contemplam o corpo docente, no qual os professores investigados estão inseridos. Assim evidenciamos que a fundamentação teórica escolhida (GOFFMAN, 1988; DUBAR, 2005; ALVES et al., 2007) nos proporcionou subsídios para identificarmos a construção das identidades dos professores universitários de Educação Física jovens doutores a que nos propomos nesta investigação. 


\section{CAPÍTULO 4 CAMINHO METODOLÓGICO}

Este capítulo apresenta a organização metodológica (Figura 11) a partir: da caracterização do estudo, que descreve a abordagem utilizada e o tipo de pesquisa; o contexto e os participantes envolvidos, considerando os critérios de inclusão e exclusão; os instrumentos de pesquisa que permitiram alcançar os objetivos propostos para a pesquisa a partir de técnicas estabelecidas; o procedimento da pesquisa, descrevendo passo a passo a coleta das informações e sua análise; os procedimentos éticos, cujas ações permitem a aplicação da investigação, garantindo a ética das informações coletadas.

Figura 11 - Organização da Metodologia da Pesquisa

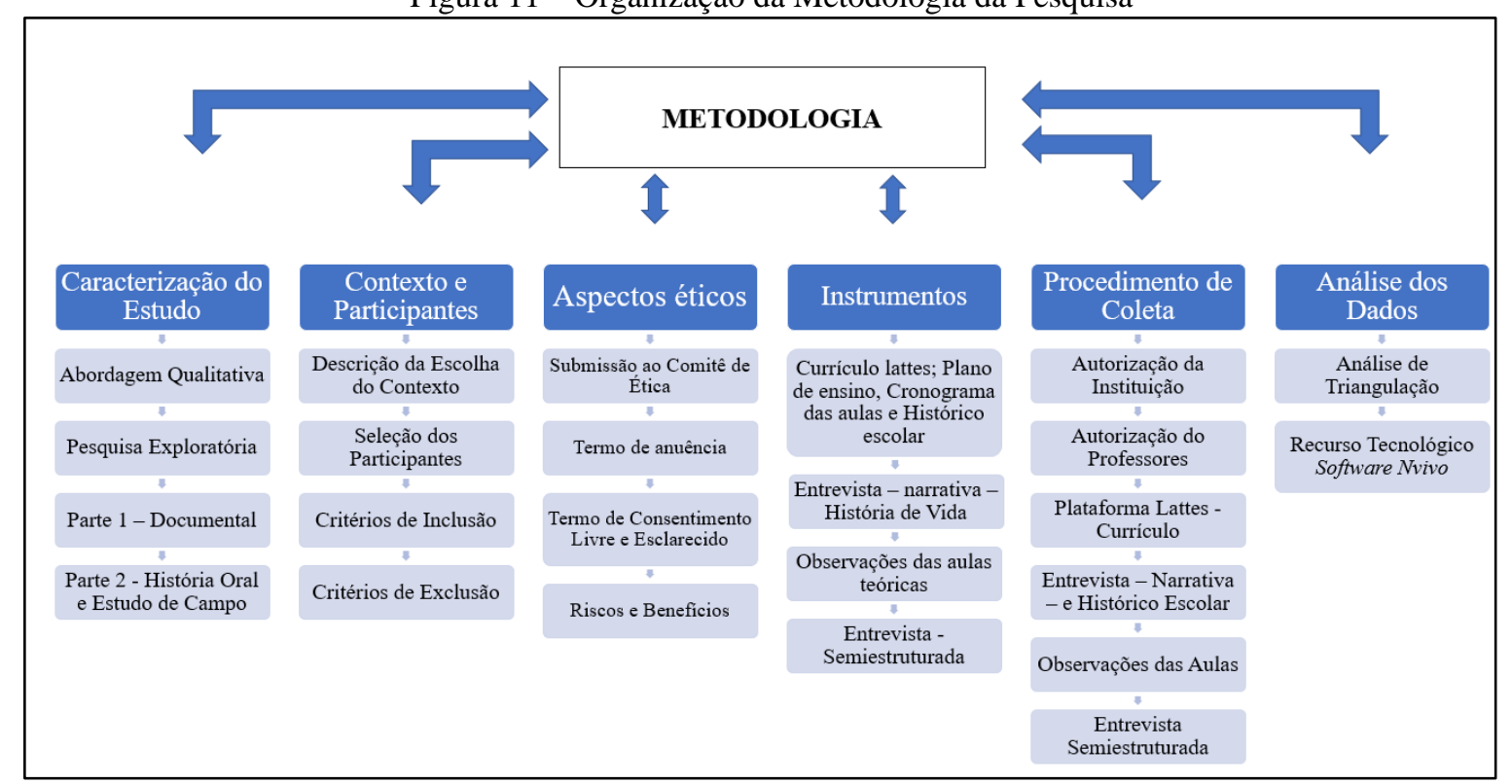

Fonte: Elaborado pela pesquisadora (2018) rever em procedimento de coleta: ‘dos' professores

\subsection{CARACTERIZAÇÃO DO ESTUDO}

A natureza desta pesquisa consiste num trabalho científico original com abordagem quantitativa e qualitativa. Quanto aos objetivos uma investigação exploratória, conforme Stebbins (2008), nas pesquisas sociais esse tipo de estudo caracteriza-se por haver pouco ou nenhum estudo científico sobre um grupo, processo, atividade ou até mesmo situações que almejam examinar. Assim levando a crer que há elementos interessantes a serem descobertos e investigados. Nesse caso, na presente pesquisa, já foi possível identificar a ausência de estudos que discutem a prática pedagógica dos professores de Educação Física universitários 
jovens doutores. A fim de justificar esse tipo de pesquisa, realizou-se um estudo da arte de dissertações e teses, assim possibilitando identificar as lacunas do objeto de investigação.

Os procedimentos técnicos consistem em: a) uma investigação documental que se utilizará do currículo vitae, plano de ensino e cronograma das aulas e histórico escolar dos professores; b) história oral, utilizando da narrativa para compreensão da história de vida do professor; e c) estudo de campo, a partir das observações das aulas teóricas; d) entrevista estruturada fundamentada pelas etapas anteriores.

É possível perceber que as etapas que contemplam o presente estudo estão relacionadas à concepção de Oliveira (2007) sobre a pesquisa qualitativa, pois se utiliza fundamentalmente de quatro procedimentos técnicos - análise documental, observação, entrevista e/ou questionário - esboçando uma figura representativa (Figura 12).

Figura 12 - Esquema conceitual para abordagem qualitativa

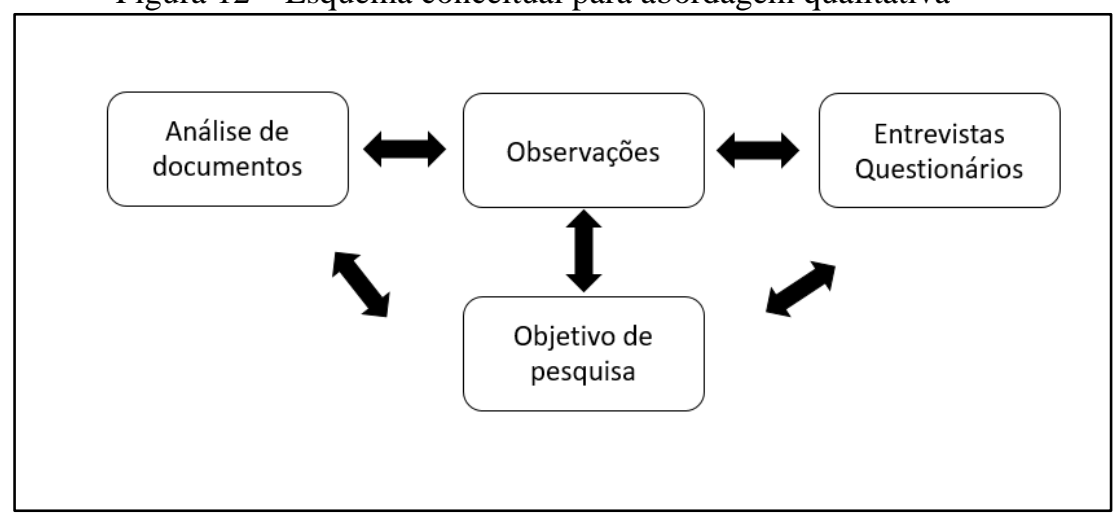

Fonte: Oliveira (2007, p. 38)

Quanto à pesquisa quantitativa, está relacionada às questões numéricas, a qual proporciona a quantificação dos dados coletados. A fim de contribuir com as informações qualitativas encontradas no presente estudo, utilizamos também as frequências dos dados abstraídos a partir da análise documental.

\subsection{CONTEXTO E PARTICIPANTES DO ESTUDO}

Os participantes deste estudo foram professores de Educação Física jovens doutores atuantes em uma universidade pública do estado de Santa Catarina. A escolha dessa universidade foi intencional, pois apresentaram 25 editais de concursos para a inserção de novos professores efetivos, contudo em apenas sete editais constavam vagas para os cursos de Educação Física de 2006 a 2016. Tal ação resultou na aprovação de 39 professores, 
considerando que o atual corpo docente dos cursos de Educação Física da instituição investigada é formado por 49 professores, dos quais 21 advindos desses últimos concursos (2006-2016) (COPERVE, 2017).

Essas informações são seguras e fidedignas, pois constam nos editais e na relação de candidatos nomeados, disponibilizada na Pró-reitora de Desenvolvimento e Gestão de Pessoas - PRODEGESP (2017), logo, o corte realizado a partir do ano de 2006 está associado à disponibilização dos editais no site da instituição. As informações que comprovam o número de docentes e identificação dos candidatos chamados para exercerem o cargo foram conseguidas no site do departamento de Educação Física da universidade pesquisada. Tais informações tiveram a veracidade confirmada a partir da disponibilização de uma lista de professores vinculados aos cursos pelo próprio órgão responsável. Também se destaca que a exigência dos editais analisados estabelecia que os professores deveriam ter pós-graduação - doutorado - concluída.

Essa primeira etapa de coleta de informações descrita se fez necessária para o reconhecimento do contexto de investigação, dessa forma justificamos a escolha pela universidade. Entretanto essa decisão se consolidou, pois a IES apresenta o conceito institucional (CI) quatro e índice geral de cursos (IGC) cinco (EMEC, 2017); oferece um dos três cursos mais antigos de Educação Física no estado de Santa Catarina; e dispõe de um programa de pós-graduação em Educação Física com conceito seis para mestrado e doutorado.

Consideramos a amostra desse estudo não-probabilística do tipo intencional, havendo a seleção dos participantes, a partir do acesso ao site do departamento dos cursos de Educação Física (Licenciatura e Bacharelado). Dessa forma identificamos 51 docentes efetivos, quatro contratados e dois voluntários. Então foram analisados os currículos lattes dos professores que constavam no item - corpo docente $(n=51)$ - o qual se encontrava atualizado conforme informações do próprio setor responsável. Utilizamos tal análise para coletar as informações sobre formação acadêmica (graduação e pós-graduação) e o ano de finalização, identificando: quatro professores mestres; um docente com doutorado em andamento; e 46 doutores. 


\subsubsection{Seleção dos participantes}

A partir dessa coleta de informações sobre os professores atuantes na universidade escolhida para investigação, foram aplicados os critérios de inclusão e exclusão aos professores que compõem o corpo docente dos Cursos de Educação Física. Essa etapa da pesquisa foi realizada em junho de 2018.

$1^{0}$ Critério de inclusão: professores que finalizaram a pós-graduação, stricto sensu doutorado - no início de 2012 até o final de 2016 (n=25), conforme distribuição na gráfico 5

Gráfico 5 - Distribuição do ano de Formação em Doutorado dos Professores de Educação Física do Ensino Superior da IES participante

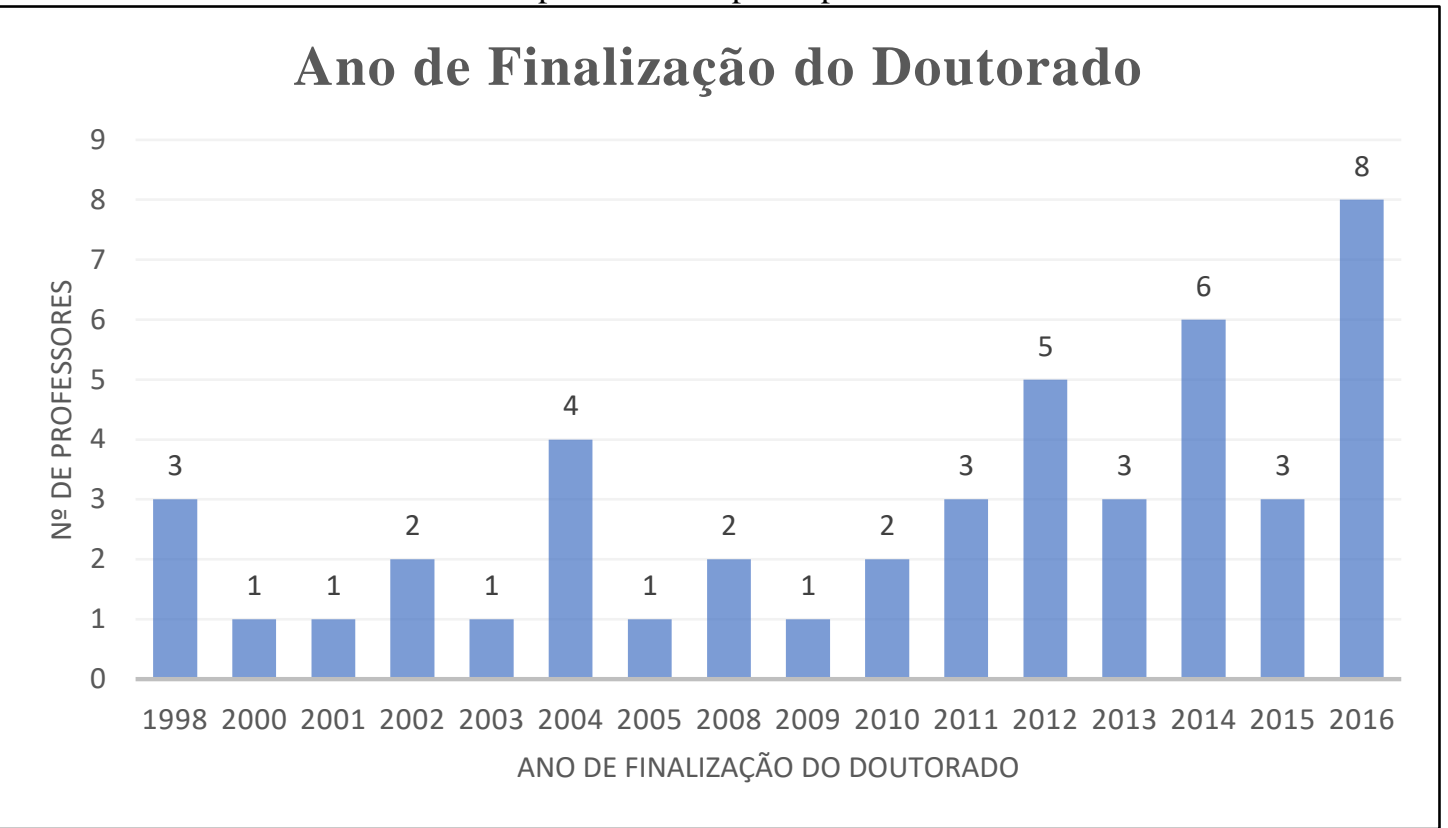

Fonte: Elaborado pela pesquisadora

$2^{\mathbf{o}}$ Critério de inclusão: professor com formação inicial em Educação Física (Licenciatura e/ou Bacharelado). Dos 25 docentes (2012 a 2016), 24 apresentaram formação em Educação Física, alcançando esse critério estabelecido; e um professor não se enquadrou, pois na formação inicial consta ciência do esporte.

$3^{\text {o }}$ Critério de inclusão: a fim de aproximar das concepções de modelos identitários descritos por Dubar (2005) e Alves et al. (2007), cujo profissional precisa ter aproximadamente quatro e cinco anos no local de trabalho, definiu-se que a inserção na universidade enquanto docente deve ter ocorrido até o ano 2014. Assim identificando 12 docentes dos anos de 1991 e 2014. Mencionar a tabela 
Tabela 11 - Ano de inserção na IES e número de doutores

\begin{tabular}{c|c|c|c|c|c|c|c|c|c}
\hline Ano & 1991 & 1997 & 1998 & 2012 & 2013 & 2014 & 2015 & 2016 & 2017 \\
\hline Doutores & 1 & 3 & 1 & 2 & 2 & 3 & 5 & 6 & 1 \\
\hline
\end{tabular}

$4^{0}$ Critério de Inclusão: o docente deverá finalizar o doutorado e inserir-se no intervalo de no máximo dois anos na instituição investigada. A partir disso, identificou-se que os docentes, em 2012, 2013 e 2014, realizaram esse processo subsequente, totalizando sete professores.

Utilizou-se como critério de exclusão: professores com contratados, visitantes, voluntários e/ou afastados por algum motivo; e atuar apenas nas disciplinas de estágio supervisionado ou da pós-graduação. Desses sete docentes selecionados, um atua na disciplina de estágio supervisionado da graduação e em disciplinas na pós-graduação, assim sendo excluído, pois tal situação dificulta análise da aula teórica, critério estabelecido na observação. A partir dos critérios estabelecidos, o resultado mostrou seis professores, dos quais dois iniciaram as atividades de docência na IES investigada em 2012, dois em 2013 e dois em 2014. No entanto quatro professores aceitaram fazer parte deste estudo.

\subsubsection{Perfil dos participantes}

Os professores participantes foram três homens e uma mulher, a fim de assegurar o sigilo das informações aqui discutidas, decidimos colocar nomes fictícios aos docentes: Larissa, Felipe, Abel e Eriberto. Todos atuam na mesma universidade pública do estado de Santa Catarina, cujo sigilo também iremos garantir, então a nomeamos Universidade Pública Catarinense - UPC.

\subsubsection{Professora Larissa}

A professora Larissa nasceu na cidade de Sarandi, no interior do estado Rio Grande do Sul, onde morou até seus dezesseis anos. Residiu até essa fase da vida com seus pais, seu irmão mais novo e sua tia. Nessa primeira fase de sua vida realizou sua formação escolar na Educação Básica em escola pública até o segundo ano do Ensino Médio. Relaciona essa permanência por ser a tia diretora de escola pública, entretanto considerou essa vivência muito boa. 
No ano de 2000 foi morar com uma tia em Florianópolis, estado de Santa Catarina, a fim de cursar o último ano do colégio em uma escola particular, que também lhe possibilitou realizar um curso de inglês. Inicialmente morou com a sua tia, em um período curto, em seguida foi residir sozinha.

Após finalizar o último ano do Ensino Médio, Larissa prestou vestibular e não obteve sucesso. A professora na época apresenta o desejo muito forte de iniciar o Ensino Superior, considerando que deveria isso aos seus pais, pois a estavam auxiliando de forma financeira suas despesas.

No ano seguinte Larissa realizou cursinho pré-vestibular e tentou novamente, inscrevendo-se no curso de Educação Física para a Universidade Pública Catarinense - UPC e no curso de Fisioterapia em uma IES privada localizada no Vale do Itajaí. Obteve aprovação nos dois processos, mas escolheu o curso de Licenciatura em Educação Física, por ser uma instituição pública e gratuita. Alega também que a escolha entre esses cursos está relacionada a questões biológicas e do corpo humano, pois esse assunto a encantava na época da escola. Ao longo da sua infância e adolescência obteve experiências esportivas, mas não foram consideradas marcantes para a escolha em cursar Educação Física, mas destaca que sempre gostou de esportes individuais, praticava natação e, às vezes, voleibol.

A professora, entre o ano de 2002 a 2006, cursou a graduação em Educação Física na UPC, com habilitação em Licenciatura, por isso apresentava currículo para atuar no contexto escolar e fora dele. Ao longo desse período se envolveu em atividades relacionadas ao ensino, pesquisa e extensão, as quais contribuíram, principalmente, para sua proximidade com o judô. Larissa nunca foi atleta dessa modalidade, a partir da monitoria no componente curricular Judô, em 2003, começou a praticar e se graduar no esporte.

Ao longo da graduação, a partir do histórico escolar, podemos observar que o índice de aproveitamento semestral (IA), o IA acumulado (IAA) e o índice das disciplinas aprovadas (IAP) ocorreu de forma crescente do primeiro ao último semestre, a professora Larissa aumentou todos esses índices ao compará-los com o semestre anterior. Iniciou o curso com $\mathrm{IA}=8,43, \mathrm{IAA}=8,43$ e IAP $=8,43$ e finalizou com $\mathrm{IA}=10, \mathrm{IAA}=8,85$ e IAP $=8,85$.

A partir do ano de 2004 começou a participar de eventos científicos de cunho regional, nacional e internacional e obteve publicações de trabalhos desse mesmo gênero, sendo artigo e resumo. Essas participações estiveram centradas mais na temática esportiva e na área de atividade física e saúde, as quais estavam associadas aos projetos de pesquisa e extensão com que a professora estava envolvida. 
No segundo semestre de 2007 realizou o processo seletivo para ingressar no mestrado, no programa de pós-graduação em Educação Física da UPC. Após aprovação, iniciou as aulas em março de 2008, sob a orientação da professora que já orientava os projetos com os quais Larissa estava envolvida desde 2004. Seu ingresso foi na área de concentração Cineantropometria e Desempenho Humano - e na linha de pesquisa - Interação Exercício Físico, Aptidão Física e Desempenho no Esporte e no Trabalho. Dessa forma, observamos que continuou o trabalho desenvolvido ao longo da graduação e do último ano enquanto pesquisadora.

Ainda em 2008, de março a julho, foi professora do projeto de extensão de iniciação ao judô vinculado à Fundação de Amparo à Pesquisa e Extensão Universitária - FAPEU. Além disso, também apresentou trabalhos relacionados à conferência e palestra sobre técnicas, formas de treinamento e arbitragem do judô.

No ano de 2010 realizou o processo seletivo para docente em uma universidade no Vale do Itajaí, em Santa Catarina, onde atuou por um ano e meio. Nessa instituição ministrou os componentes curriculares de Cineantropometria, Trabalho de Conclusão de Curso - TCC e Biomencânica.

Em 2011, ainda trabalhando na IES, foi aprovada no processo seletivo de doutorado na UPCC, área de concentração - Biodinâmica do Desempenho Humano - e linha de pesquisa - Exercício Físico e Desempenho no Esporte e no Trabalho.

No período de 2011 a agosto de 2013 recebeu bolsa de fomento da CAPES-DS, encerrada nesse último ano, pois foi aprovada em primeiro lugar no concurso para professora em uma universidade pública de Pernambuco. Larissa escolheu permanecer no mesmo estado em que residia - Santa Catarina. Defendeu a tese em fevereiro de 2014, relacionada ao judô, contemplando os efeitos agudos, sessão de treino e os indicadores de fadiga e dano muscular.

Nos três anos seguintes $(2015 ; 2016 ; 2017)$ recebeu prêmios, o primeiro ainda fruto do estudo desenvolvido no doutorado, que lhe possibilitou ganhar o Prêmio UPC de Tese 2015 - Categoria Destaque. Em 2016 e 2017 foram menções honrosas em eventos científicos: XVII Congresso Brasileiro de Biomecânica, Sociedade Brasileira de Biomecânica e VII Simpósio em Neuromecânica Aplicada, Pontifícia Universidade Católica do Paraná.

Além da formação acadêmica de graduação e pós-graduação, Larissa realizou cursos de curta duração entre 2004 a 2010, os quais desenvolvidos em congressos e na própria instituição em que estudava. Os cursos estiveram relacionados a sua área de pesquisa como judô, biomecânica e fisiologia do esporte, além de um curso da língua inglesa e arbitragem de triatlo. 
Atualmente, além da docência na graduação, é coordenadora de extensão dos cursos de Educação Física, também atua no programa de pós-graduação do centro a que está vinculada. Sua atuação está concentrada nas subáreas da Educação Física: biomecânica do esporte; cineantropometria; e desempenho humano, além disso é revisora de quatro periódicos de Qualis dois A2, depois um B1 e outro B2. Em virtude da docência também realiza(ou) orientações de iniciação científica, TCC, dissertações e teses e participa(ou) de bancas avaliadoras de graduação, pós-graduação stricto sensu e de concurso público

Em sua trajetória, enquanto pesquisadora na área da Educação Física, podemos considerar que essa etapa iniciou na graduação e permanece até hoje. Assim construímos uma tabela que nos permitirá identificar sua contribuição científica para a área em que está inserida, a qual foi categorizada a partir de triênio (iniciado em 2004, quando ocorreu a primeira publicação); artigos completos (AC) publicados em periódicos; capítulo de livro (CL), publicações em anais de eventos - trabalho completo (TC), resumo expandido (RE) e resumo (R); artigos aceitos (ACE) para publicação (Tabela 12).

Tabela 12 - Produção do conhecimento da Professora Larissa em sua trajetória acadêmica e profissional

\begin{tabular}{cccccccc}
\hline $\begin{array}{c}\text { Publicações } \\
\text { Triênio }\end{array}$ & AC & CL & TC & RE & R & ACE & TOTAL \\
\hline $\mathbf{2 0 0 4 - 2 0 0 6}$ & 1 & - & - & - & 8 & - & 9 \\
\hline $\mathbf{2 0 0 7 - 2 0 0 9}$ & 14 & - & 4 & - & 14 & - & 32 \\
\hline $\mathbf{2 0 1 0 - 2 0 1 2}$ & 13 & 2 & - & - & 7 & - & 22 \\
\hline $\mathbf{2 0 1 3 - 2 0 1 5}$ & 10 & - & - & 4 & 3 & - & 17 \\
\hline $\mathbf{2 0 1 6 - 2 0 1 8}$ & 20 & - & - & 3 & 9 & 1 & 33 \\
\hline $\mathbf{2 0 1 9 - a t u a l}$ & 1 & - & - & - & - & 3 & 4 \\
\hline Total & 59 & 2 & 4 & 7 & 41 & 4 & 117 \\
\hline
\end{tabular}

Fonte: Adaptado do currículo lattes da Professora Larissa

A partir da tabela podemos identificar que houve 117 produções científicas da Professora Larissa, sendo quatro aceitas, porém em aguardo para publicação. Observamos que a docente concentra seus trabalhos em artigos científicos publicados em periódicos $(n=59)$, seguindo para resumos publicados em anais de eventos $(n=41)$. No entanto trabalhos completos e os resumos publicados em anais estiveram mais presentes no período da graduação. Na pós-graduação e na docência universitária predominou o artigo. Ao longo do mestrado, em 2011, construiu dois capítulos de livro na disciplina de Metodologia de Pesquisa, o qual discute sobre essa questão em pesquisas quantitativas.

Desde o início de suas atividades científicas (2004) suas produções estiveram centradas à temática do esporte, mais especificamente envolvendo lutas, contemplando 
também a área de biomecânica e neuromuscular. Também identificamos, no período analisado 2004-2019, que a professora apresentou autoria primária $(n=33)$, mas se sobressaiu como coautora $(n=84)$.

Também foram identificados 27 trabalhos na Web of Science, os quais contêm 98 citações suas, e na Scielo há oito trabalhos com 10 citações realizadas de suas obras. Embora seja jovem doutora, a Professora Larissa apresenta experiência científica relevante, entretanto as experiências profissionais que ultrapassam as paredes da universidade não pareceram ao longo das entrevistas e no currículo lattes.

\subsubsection{Professor Felipe}

Ao longo das entrevistas o docente pouco relatou sobre seu contexto familiar, também, como Larissa, predominaram as experiências em ambientes esportivos, de formação desde a Educação Básica até o Ensino Superior. Quanto a sua trajetória pessoal, iremos narrar as informações que o próprio professor nos forneceu e que constam nos documentos analisados.

O Professor Felipe também é natural do Rio Grande do Sul, do município de Constantina, seus pais eram agricultores, produtores rurais. Seu convívio nesse contexto social foi até os dez anos de idade, após esse período Felipe e sua família se mudaram para a cidade de Santa Maria, hoje considerada a quinta cidade mais populosa do estado. Foi nessa cidade que passou o final de sua infância, adolescência e início da vida adulta, cursando a graduação, Licenciatura em Educação Física, e a pós-graduação lato sensu em Atividade Física, Desempenho Motor e Saúde.

Desde a época em que residia em Constantina, apresentou envolvimento significativo com o esporte. Revela que houve um Tenente da Polícia Militar, ex-brigadiano aposentado, que construiu uma escolinha de voleibol, da qual fazia parte, esse envolvimento o docente considera como fator influenciador na sua escolha pela formação profissional em Educação Física. Ao se mudar para Santa Maria continuou desenvolvendo a prática esportiva, participou de alguns campeonatos em equipes competitivas de alto nível.

Apesar de suas vivências com o esporte e a proximidade com a Educação Física antes de ingressar no Ensino Superior, Felipe ainda ficou na dúvida ao prestar o vestibular para a Universidade Pública do Rio Grande do Sul - UPRS (nome fictício). Inicialmente realizou um processo seletivo específico na instituição, que ocorria a cada ano do Ensino Médio, concorrendo para o curso de Engenharia Ambiente, mas não foi selecionado. Então ficou 
trabalhando, e no ano seguinte prestou vestibular normal para Educação Física, quando foi aprovado.

Felipe ingressou no curso de Licenciatura em Educação Física em 2002, sua formação ainda estava relacionada ao currículo que permitia atuar no contexto escolar e fora dele. Então as disciplinas realizadas nesse processo formativo passaram pelo universo de atividade física e saúde, treinamento esportivo, educação, isto é, apresentava um currículo generalizado.

Ao longo de sua formação proporcionou atividades de ensino, pesquisa e extensão, evidenciadas nos anos de 2004 e 2005 da graduação, havendo continuidade quando realizou a especialização, em 2006 e 2007. A primeira esteve relacionada à monitoria na disciplina atletismo, com a qual apresentava forte proximidade, assim participando também do núcleo de pesquisa do docente responsável. Realizou o estágio no Programa Segundo Tempo, nas modalidades de handebol e atletismo.

A partir desse envolvimento com o atletismo também participou do projeto de extensão nessa mesma modalidade, possibilitando o ensino e o desenvolvimento desse esporte em um bairro específico de Santa Maria. Além desses projetos de extensão, esteve participando no projeto UPRS em movimento como monitor de musculação e na organização e planejamento do $3^{\circ}$ Festival de Atletismo Escolar do Centro de Educação Física e Desportos da UPRS.

Quanto à pesquisa, teve envolvimento no laboratório de biomecânica, como estagiário de iniciação científica, o que lhe possibilitou se envolver em projetos de pesquisa. Ao analisar o currículo lattes do docente, identificamos que essa experiência com a produção do conhecimento esteve ao final do curso de graduação, no ano de 2005, apresentando dois trabalhos completos e sete resumos.

No ano de 2007, ainda cursando o segundo ano do curso de especialização, foi aprovado no programa de pós-graduação para cursar mestrado na UPC, no estado de Santa Catarina. Ingressou na área de concentração de Cineantropometria e Desenvolvimento Humano, a qual, atualmente, é titulada Biodinâmica do Movimento, cuja linha de pesquisa era Exercício Físico, Aptidão Física e Desempenho no Esporte e no Trabalho.

Ao ingressar no mestrado (2007), inseriu-se no Laboratório de Biomecânica, consequentemente, começou a participar de três projetos de pesquisa relacionados à área esportiva, dois especificamente na área do atletismo. No primeiro ano do mestrado (2007) realizou cinco formações complementares com a carga horária de 3 a 6 horas, nenhuma ocorreu na universidade vinculada, as quais foram: Iniciação Esportiva; Futsal; Controle de Carga; Atividade física para populações especiais; Planificação de treinamento no esporte. 
No segundo ano do mestrado recebeu bolsa da CAPES-DS, mas ficou pouco tempo, pois no ano de 2008 foi contratado como professor horista de uma faculdade privada na Grande Florianópolis. Tal experiência lhe possibilitou as primeiras orientações TCC e aferições como membro avaliativo de bancas desse trabalho acadêmico.

Finalizou o mestrado em fevereiro de 2009, defendendo sua dissertação sobre fisiologia do exercício e neuromusculares de velocistas em provas de atletismo. Quanto à experiência docente na instituição privada, Felipe possuía a carga horária de 15 horas semanais no curso de Graduação em Educação Física e ministrou os seguintes componentes curriculares: medidas e avaliação no esporte; voleibol; atletismo; e condicionamento físico I

No ano de 2011 recebeu bolsa da CAPES - DS até o final do doutoramento. Houve um período em que teve que aumentar seu envolvimento na construção do projeto da tese, optando por sair do trabalho para se dedicar apenas aos estudos. No penúltimo ano do doutorado realizou o curso de árbitro de atletismo pela Confederação Brasileira de Atletismo - CBAT (24 h). Em sua tese, entretanto, distanciou-se um pouco da modalidade de atletismo, a qual permanecia estudando. Assim deixou a especificidade do esporte individual e passou para a corrida no esporte coletivo, defendendo o estudo (2014).

No semestre em que finalizou o doutorado, realizou o processo seletivo para professor em uma universidade estadual, onde lecionou apenas um semestre (3/20147/2014), na disciplina de medidas e avaliação, pois ingressou como docente adjunto na instituição onde é vinculado.

Conforme seu currículo lattes, realizou formações complementares do período de 2004 a 2013, totalizando 29 cursos com curta duração relacionados à informática, línguas (curso de extensão de inglês - 2004-2005 - e de italiano -2006-2006) e da própria área da Educação Física. Essas formações ocorreram nas universidades em que esteve vinculado a eventos científicos e instituições isoladas. Nas temáticas dos cursos predominaram o esporte, a biomecânica e a atividade física e a saúde.

Atualmente (2019), ainda continua na área esportiva, leciona a disciplina de Teoria e Metodologia do Voleibol para o curso Bacharelado em Educação Física e para EFC, também está no componente curricular estágio em avaliação e prescrição de exercício. Na pósgraduação é subcoordenador do programa e atua como docente na disciplina de Biomecânica, em parceria com outros três professores. Também ministra um projeto de extensão em voleibol e atua na pesquisa na área de biodinâmica do movimento com estudos direcionados à avaliação neuromuscular de atletas, demandas físicas no esporte intermitente, um pouco 
mais para biomecânica musculoesquelética. Conforme seu currículo lattes, possui seis alunos concluintes de graduação e dois estudantes de mestrado na UPC.

Ainda, tal trajetória foi marcada em produções técnicas como: participação em uma mesa redonda, transmitido no programa de rádio/tv (2016) sobre os aspectos Fisiológicos e Neuromusculares no Exercício de Alta Intensidade: implicações para a saúde e desempenho. Também ministrou cursos de curta duração considerado ou não extensão universitária sobre: oficina de atletismo (2005); Eletromiografia aplicada ao Esporte (2008); Eletromiografia aplicada ao Esporte (2009); Princípios da Eletromiografia (2009); Avaliação de parâmetros neuromusculares com uso de plataforma de força e suas aplicações para o esporte (2010); Fundamentos da Eletromiografia (2010).

Quanto às produções do conhecimento identificamos que participou na construção de dois livros. O primeiro foi publicado em 2011, sobre metodologia de pesquisa quantitativa, contribuiu em dois capítulos. E o segundo foi sobre um capítulo que abordava os saltos verticais para avaliação da potência muscular, no livro de Biodinâmica do Movimento Humano, publicado em 2017.

Nas produções bibliográficas averiguamos que constam 66 trabalhos na Web of Science, totalizando 163 citações. No indexador Scielo possui quatro trabalhos e nenhuma citação, enquanto no Scorpus foram 26, com 172 citações. Ao longo da sua carreira acadêmica e profissional pudemos identificar a quantidade de produção de conhecimento que o professor Felipe possibilitou para o meio científico da área de Educação Física (Tabela 13). O docente iniciou sua publicação em 2005, mas organizamo-la por categorizada a partir de triênio, como fizemos com o material publicado da professora Larissa: artigos completos (AC) publicados em periódicos; capítulo de livro (CL), publicações em anais de eventos trabalho completo (TC), resumo expandido (RE) e resumo (R); artigos aceitos (ACE) para publicação

Tabela 13 - Produção do conhecimento do Professor Felipe em sua trajetória acadêmica e profissional

\begin{tabular}{|c|c|c|c|c|c|c|c|}
\hline $\begin{array}{ll} & \text { Publicações } \\
\text { Triênio } & \end{array}$ & $\mathbf{A C}$ & CL & $\mathbf{T C}$ & $\mathbf{R E}$ & $\mathbf{R}$ & $\mathrm{ACE}$ & TOTAL \\
\hline 2004-2006 & 1 & - & 2 & 1 & 10 & - & 14 \\
\hline 2007-2009 & 8 & - & 2 & - & 12 & - & 22 \\
\hline $2010-2012$ & 13 & 2 & 1 & - & 10 & - & 26 \\
\hline 2013-2015 & 13 & - & 2 & 2 & 1 & - & 18 \\
\hline 2016-2018 & 16 & 1 & - & - & 3 & - & 20 \\
\hline 2019-atual & 1 & - & - & - & - & 2 & 3 \\
\hline Total & 52 & 3 & 7 & 3 & 36 & 2 & 103 \\
\hline
\end{tabular}

Fonte: Adaptado do currículo lattes do Professor Felipe 
Identificamos que as experiências profissionais do Professor Felipe estiveram centradas ao universo universitário, não constando experiência em outros espaços de atuação do profissional de Educação Física. Verificamos a presença ao longo da sua carreira de produção científica nas diferentes modalidades e técnicas. Também realizou formações do tipo não formal da graduação até o penúltimo ano de doutorado.

\subsubsection{Professor Eriberto}

Professor Eriberto nasceu na cidade do Jaboticabal, interior do estado de São Paulo, onde residiu até seus 17 anos de idade. Possui dois irmãos, os quais são gêmeos, seus pais são divorciados, ambos veterinários e trabalhavam em universidades. Após o divórcio foi morar com sua mãe e seus irmãos. A infância e adolescência de Eriberto foi marcada por diferentes experiências esportivas, seja em esportes individuais e/ou coletivos, em um clube que frequentava em sua cidade. A prática esportiva foi de cunho recreacional e competitiva.

Para iniciar a faculdade, em 1994, teve que mudar de cidade, então passou a residir em Rio Claro, no estado de São Paulo. Ao ingressar no curso de Bacharelado em Educação Física, em uma universidade pública - Universidade Pública Rio Claro - UPRC (nome fictício), começou a fazer parte do laboratório de fisiologia do exercício. No segundo ano da graduação foi contemplado como bolsista do CNPq, em cujo currículo lattes apontam como palavras-chave a característica da bolsa lactato mínimo; ciclismo; avaliação; lactato. Nesse período continuou competindo e isso lhe possibilitou fazer uma relação teoria/prática, a qual o Eriberto considera uma de suas maiores riquezas da formação.

Conforme o currículo lattes e as entrevistas realizadas, não foram identificadas experiências profissionais e envolvimentos em atividade de extensão no período da graduação. Ao encerrar o Bacharelado em Educação Física (1997), no ano seguinte ingressou no mestrado (1998) na mesma instituição e com o mesmo orientador da graduação em ciências da motricidade como área em motricidade humana.

Durante o período em que esteve no mestrado também pôde auxiliar na formação de estudantes da graduação, contribuição com seu orientador de mestrado nas orientações de TCC dos alunos da graduação. Em 1999 foi convidado para lecionar a disciplina de Treinamento Desportivo (duas horas semanais) em uma universidade particular na cidade de Franca, a $250 \mathrm{~km}$ de distância da cidade de Rio Claro, onde residia. Essa foi sua rotina semanal até finalizar o mestrado. 
No período de graduação e mestrado que passou na cidade de Rio Claro (1994-2000), Eriberto permaneceu competindo no triatlo. Além disso, considerou uma fase muito produtiva, academicamente falando, pois se envolveu com pesquisas e publicações. Nessa época seu TCC foi publicado em uma revista australiana, considerada atualmente como uma das mais conceituadas.

Finalizou o mestrado com a dissertação sobre fisiologia do exercício e o ciclismo, quando se mudou para uma cidade próxima a Franca, com 6.000 habitantes, a qual faz divisa entre os estados de São Paulo e Minas Gerais, na região de Serra da Canastra. Sua carga horária aumentou na universidade em Franca, onde permanecia dois ou três dias, e o resto da semana ficava na cidade em que morava, onde tinha sociedade com um amigo em uma empresa de ecoturismo e esporte de aventura.

Permaneceu com vínculo nessa universidade, em Franca, entre 1999-2008, nesse período lecionou nos cursos de Bacharelado e Licenciatura em Educação Física as seguintes disciplinas: metodologia e técnicas de pesquisa (08/2000-12/2003); atividade física e promoção da saúde (02/2000-12/2004); fisiologia do exercício (02/2005-12/2005); metodologia do treinamento esportivo individual e coletivo (02/1999-12/2008); socorros de urgência (02/2002-12/2008); esportes e práticas corporais alternativas (02/2005-12/2008). Em 2007-2008 foi preparador físico na Associação Francana de Voleibol.

Ainda nesse período vivido junto à IES em Franca, obteve prêmios e menção honrosa. Nos anos de 2000, 2002 e 2003 recebeu o Prêmio Dr. Clovis Eduardo Pinto Ludovice como melhor orientador de TCC do curso de Bacharelado em Educação Física, e em 2003 também foi considerado no curso de Licenciatura em Educação Física. Nos anos de 2006 e 2008 recebeu menção honrosa em dois encontros científicos: primeiro foi no $5^{\circ}$ Encontro de Iniciação Científica e de Professores Pesquisadores; e o segundo foi $2^{\circ}$ Encontro de Pesquisadores da Pós-Graduação. No ano de 2007 recebeu o Prêmio de "Profissional de Educação do ano de 2006”.

Verificamos que em 2010 ministrou curso de curta duração e duas clínicas envolvendo o esporte de natação: avaliação aeróbica e prescrição de treinamento em nadadores e clínica de natação: gold medal alta performance. E no ano de 2011 proferiu uma palestra sobre esporte de endurance na natureza: caracterização fisiológica e aplicações para o treinamento.

No ano de 2009 o Professor Eriberto iniciou o doutorado no programa de pósgraduação em Educação Física na UPC, sob orientação do mesmo professor da UPRC. Ingressou na área de concentração em Biodinâmica do Desempenho Humano, na linha de 
pesquisa de Estudo de aptidão física, morfologia e função. Além disso, foi inserido como pesquisador no Laboratório de Esforço Físico (LAEF) na linha de avaliação e desempenho humano.

Nesse mesmo ano (2009) passou no processo seletivo para docente em outra universidade pública no estado, lecionando como professor substituto até 2014. Ao longo desse período lecionou no curso de graduação em Educação Física nas disciplinas de cineantropometria, medidas e avaliação em Educação Física, metodologia do atletismo e treinamento esportivo I.

Além do doutorado, no ano de 2010, realizou o curso de técnico de triatlo nível II com a carga horária de 40 horas. Percebemos que a presença esportiva do triatlo continuou presente em sua formação profissional como em suas investigações. Em sua tese, defendeu o teste máximo de três minutos em ciclo-ergômetro isocinético, que aborda em sua especificidade o ciclismo. No ano seguinte, em 2011, no período de 10 a 19 de julho, realizou o estágio científico na Universidade de Brighton, no Reino Unido.

Também identificamos em seu currículo lattes participações em projetos de pesquisa, registrados a partir da inserção no doutorado. Os temas relacionados à fisiologia do exercício contemplando o esporte, no total foram contabilizados quatro projetos, um deles associado à sua tese.

No ano seguinte, após o término do doutorado, recebeu bolsa pela CAPES para realizar o pós-doutorado na UPC, a área de formação escolhida foi na Educação Física com a subárea de performance humana e fisiologia do esforço. Encerrou esse processo em 2014, quando ingressou como professor na instituição pública onde leciona atualmente.

Hoje, é professor adjunto com dedicação exclusiva, ainda é pesquisador do LAEF e atua nas disciplinas de Teoria e Metodologia do Treinamento Esportivo e Adaptações Orgânicas ao Exercício, apenas para o curso de Bacharelado em Educação Física. Também é docente permanente no programa de pós-graduação em sua instituição, orientando estudantes de mestrado (M) e doutorado (D). Leciona as disciplinas de Bases Fisiológicas do Desempenho Humano (M/D), em colaboração com outros dois professores, e Métodos Avançados de Pesquisa em Biodinâmica do Desempenho Humano (D) como professor convidado nacional.

Ao longo da sua entrevista mencionou que é coordenador do projeto na sala de musculação para a comunidade com envolvimentos de estudantes bolsistas e quando a piscina está em funcionamento, também tem um projeto desenvolvido naquele espaço. 
Constatamos em seu currículo que, no ano de 2016, participou de uma mesa redonda em um programa de rádio ou tv, juntamente como professor Felipe e mais dois docentes. A discussão da mesa foi sobre aspectos fisiológicos e neuromusculares no exercício de alta intensidade: implicações para a saúde e desempenho.

Desde o ano de 2008 até hoje (2019) Eriberto é membro avaliativo de periódicos científicos na área da Educação Física e afins. Verificamos que participa como revisor de 12 periódicos nacionais e internacionais com os respectivos qualis A1 ( $n=3)$, A2 (n=1), B1 $(n=4), B 2(n=1), B 3(n=1)$ e B4 $(n=2)$.

Em 1998 realizou duas formações complementares, a primeira foi sobre Clínica de Triatlo, com 16 horas no serviço social do comércio - SESC de São Carlos; e a outra foi Atividade física para crianças e adolescentes, com 6 horas de carga horária no Centro de estudos do laboratório de aptidão física de São Caetano do Sul - CELAFISCS.

Enquanto cursava o mestrado, proferiu duas palestras em uma universidade privada em Franca, na qual acabou lecionando. A primeira foi sobre Perspectivas no Triatlo, em 1997; e a segunda em 1999, sobre o Ironman Triatlo: a superação do limite humano. No período de 2004 a 2007 ministrou cursos de curta duração, três deles categorizado como extensão universitária. As temáticas abordadas foram sobre: esportes de aventura (2004); trekking de altitude (2005); treinamento de triatlo em academias (2006); a prática do triatlo em academias (2006); fundamentos e prescrição do treinamento aeróbico (2007).

Quanto as suas publicações de trabalhos científicos, identificamos que iniciaram no terceiro ano da graduação (1996) a partir de resumo em anais de eventos. Atualmente, em seu currículo lattes, constatamos que há 65 resumos e um trabalho completo em anais de congressos; um texto em jornal de notícias (2016); dois livros; 66 artigos completos publicados em periódicos. Conforme a Tabela 14, foram organizadas suas produções científicas ao longo da sua trajetória profissional, tal qual apresentamos a da Professora Larissa e a do Felipe. 
Tabela 14 - Produção do conhecimento do Professor Eriberto em sua trajetória acadêmica e profissional

\begin{tabular}{|c|c|c|c|c|c|c|c|}
\hline $\begin{array}{ll}\text { Triênio } & \text { Publicações } \\
\end{array}$ & $\mathrm{AC}$ & CL & $\mathbf{T C}$ & $\mathbf{R E}$ & $\mathbf{R}$ & ACE & TOTAL \\
\hline 1995-1997 & - & - & 1 & - & 9 & - & 10 \\
\hline 1998-2000 & 3 & - & - & - & 15 & - & 18 \\
\hline 2001-2003 & 6 & - & - & - & 4 & - & 10 \\
\hline 2004-2006 & 1 & - & - & - & 4 & - & 5 \\
\hline 2007-2009 & 3 & - & - & - & 6 & - & 9 \\
\hline 2010-2012 & 13 & 2 & - & - & 15 & - & 30 \\
\hline 2013-2015 & 22 & - & - & - & 7 & - & 29 \\
\hline 2016-2018 & 17 & - & - & - & 5 & 2 & 24 \\
\hline 2019-atual & 1 & - & - & - & - & 1 & 2 \\
\hline Total & 66 & 2 & 1 & - & 65 & 3 & 137 \\
\hline
\end{tabular}

Fonte: Adaptado do currículo lattes da Professor Eriberto

Percebemos que, a partir das pesquisas realizadas no laboratório que resultou em alguns trabalhos acadêmicos e científicos, a formação formal de graduação e mestrado e a formação não-formal em cursos de curta duração, levaram Eriberto ao aperfeiçoamento nas modalidades esportivas que praticava. consequentemente foi reconhecido e convidado a explanar aos estudantes de Educação Física sobre a modalidade de Triatlo.

\subsubsection{Professor Abel}

Professor Abel nasceu em 1977, também é natural do Rio Grande do Sul, da cidade chamada Mata, que dista $100 \mathrm{~km}$ de Santa Maria. Sua família vem da cultura de agricultores, seus pais atuam nessa área. $\mathrm{O}$ casal teve nove filhos e Abel foi o oitavo, todos auxiliavam no trabalho agrícola. Aos sete anos de idade, aproximadamente, mudaram para a cidade de Santa Maria, mas continuaram com o mesmo trabalho, envolvidos em chácara.

Foi nesse período que Abel iniciou sua educação formal, juntamente com seus irmãos da mesma faixa etária. "No período de primeira à quarta série eu tinha uma professora, que atendia todas essas séries no mesmo local", mencionou Abel.

Sua formação escolar foi em escola pública, que tinha uma estrutura razoável, foi onde Abel conheceu o esporte e se aproximou da atividade física em geral, por volta da sétima série. Ele se recorda muito desse período e do professor de Educação Física, o único de quem lembra, pois foi esse docente que apresentou o handebol a Abel.

Iniciou a prática do handebol ainda quando era desenvolvido na grama, isto é, handebol de campo, além disso vivenciou outras modalidades como vôlei e futsal. Entretanto 
se direcionou mais ao handebol, participando de campeonatos escolares e depois ingressou em um clube em sua cidade, chamado Corinthians, onde competiu em nível estadual. Também jogou no Campeonato Gaúcho, Campeonato Brasileiro, Jogos Abertos Brasileiros, Jogos abertos do Rio Grande do Sul, dentre outros.

Sua adolescência foi fundamentada nos estudos e na prática esportiva. Com 18 anos ingressou no exército brasileiro, permanecendo em serviço obrigatório por um ano e com a prática esportiva. No ano em que esteve no exército, prestou o vestibular para o curso de Licenciatura em Educação Física, na Universidade Pública do Rio Grande do Sul - UPRS, a mesma em que o professor Felipe estudou.

A escolha pela Educação Física esteve atrelada ao próprio interesse, envolvimento com o esporte, conhecia profissionais da área e os colegas que jogavam handebol com ele também optaram pelo curso. Então ingressou, em 1998, no curso de Licenciatura em Educação Física, cujo currículo lhe possibilitava atuar dentro e fora da escola. Também permaneceu jogando handebol, em virtude disso, acabou tornando-se árbitro dessa modalidade e depois gestor na Federação Gaúcha.

Abel sempre teve um olhar mais voltado à prática profissional e não para a pesquisa propriamente dita, mas o ambiente da universidade que cursou apresentava fortemente a cultura investigativa. Em virtude disso, acabou se envolvendo em projetos de pesquisa, como voluntário, por três anos, isso o fez comparecer em eventos científicos. Ficou vinculado a um grupo de pesquisa de medidas e avaliação na Educação Física.

Quanto à extensão, também foi uma prática realizada ao longo da graduação. Abel foi contemplado com bolsas de estudos relacionadas à participação em projetos desse caráter. Participou de projetos de gestão esportiva até sobre iniciação esportiva, vinculado ao handebol.

Nesse período da graduação morou com seus pais, também realizou o curso de árbitro de futebol (2000-2001). Começou a atuar como árbitro nos finais de semana, o que contribuía em seu orçamento financeiro e onde permaneceu um bom tempo, até o mestrado, participando até do campeonato gaúcho.

Em 2002 finalizou o curso de Educação Física e ingressou na especialização em Fisiologia do Exercício. Entre 2003 e 2004 atuou como preparador físico da equipe adulta masculina de handebol da sua cidade. No final de 2003 realizou o processo seletivo ao curso de mestrado no programa de pós-graduação em Educação Física da UPC, onde ingressou, em 2004, na área de concentração atividade física relacionada à saúde e na linha de pesquisa de cineantropometria e desempenho humano. 
Ao encerrar o mestrado, em 2006, fez o processo seletivo para professor para os Cursos de Educação Física em uma universidade pública na região sul do estado do Paraná. Foi aprovado e assumiu 20 horas de aula de handebol. Conforme o currículo lattes de Abel, em agosto do mesmo ano ingressou em outra universidade pública no planalto norte do mesmo estado em que atuava como docente, ali permanecendo até o ano de 2013.

Nessa universidade do planalto norte no Paraná atuava nos cursos de Educação Física, regime de contratação de 40 horas semanais com dedicação exclusiva. No período em que lecionou nessa IES atuou na graduação, nas disciplinas: crescimento e desenvolvimento humano; orientação de trabalho de conclusão de curso. Na especialização atuou em bioestatística e atividade física e saúde. Também foi tutor do programa PET-Saúde (Programa de Educação pelo Trabalho para a Saúde) junto ao Núcleo de estudos em Saúde Coletiva.

Ainda lecionando, ingressou no doutorado em outra universidade pública no estado do Paraná (Universidade Pública do Paraná - UPP - nome fictício), a partir de uma vaga que correspondia a docente atuante no Ensino Superior público no estado. Seu doutoramento estava relacionado à área de concentração de exercício e esporte e linha de pesquisa de atividade física e saúde. Nesse período participou de um grupo de pesquisa em uma IES particular, também realizou o doutorado sanduíche em Portugal, na Universidade de Porto.

Encerrou o doutorado no primeiro semestre de 2013, com a tese relacionada à multidimensionalidade de atividade física de lazer em adultos. Nesse mesmo semestre realizou o concurso para docente nos cursos de Educação Física da UPC, onde foi aprovado e iniciou sua atuação em setembro de 2013.

Ao longo de sua trajetória profissional dentro da UPC foi se envolvendo com as ações desenvolvidas na IES, estreitou seu envolvimento institucional ultrapassando o departamento de Educação Física. Atualmente ministra disciplinas nos cursos de Educação Física e na Residência multiprofissional em Saúde da Família e no programa de pós-graduação em Educação Física (produção e veiculação do conhecimento em Educação Física). Possui funções de gestão relacionadas à residência multiprofissional, do centro, do departamento, dos cursos e da pós-graduação em Educação Física.

Além dessas funções, atualmente exerce o papel de professor orientador de iniciação científica $(n=1)$ e de mestrado $(n=3)$. Verificamos que orientou dois estudantes de mestrado, 11 de curso de aperfeiçoamento/especialização, 14 de graduação e oito de iniciação científica. Também participou como membro de bancas avaliativas de qualificação de trabalhos de pós-graduação $(n=22)$ e de defesa na graduação $(n=23)$, no 
aperfeiçoamento/especialização $(n=19)$ no mestrado $(n=19)$ e no doutorado $(n=19)$.

Também identificamos que, a partir da sua graduação (1998) até o ano de 2018, realizou cursos de curta duração, o que lhe possibilitou uma formação complementar. Totalizou aproximadamente 63 cursos nesse período, em sua maioria com a temática relacionada ao esporte e à atividade física e saúde. Houve também relacionadas às questões científicas, gestão e cursos de extensão de línguas.

Sua participação em projetos de pesquisa $(n=16)$ e extensão $(n=7)$ também fizeram parte de sua caminhada, desde o período em que estava na graduação até a docência. Nesses projetos obteve função de integrante pesquisador até como coordenador todos em sua área de atuação.

Também identificamos que é membro do corpo editorial e revisor de periódico brasileiro (qualis B2) e revisor de outros três (qualis B1 n=2 e qualis B3 n=1). Quanto aos seus trabalhos científicos, estão dispostos no Scielo $(n=27)$ com 67 citações realizadas; Scopus $(n=256)$ com 296 citações; e em outros $(n=140)$ com 1186 citações. Quanto à produção do conhecimento publicada, categorizamos conforme o currículo lattes, diferente dos demais entrevistados anteriormente mencionados, pois o professor Abel ainda menciona que foram publicados artigos em anais de eventos (AA), em virtude disso incluímos mais essa categoria (Tabela 15).

Tabela 15 - Produção do conhecimento do Professor Abel em sua trajetória acadêmica e profissional

\begin{tabular}{ccccccccc}
\hline \multirow{2}{*}{ Publicaçnióes } & AC & CL & TC & RE & R & AA & ACE & TOTAL \\
\hline $\mathbf{1 9 9 8 - 2 0 0 0}$ & - & - & - & - & 5 & - & - & 5 \\
\hline $\mathbf{2 0 0 1 - 2 0 0 3}$ & 4 & - & 10 & - & 25 & - & - & 39 \\
\hline $\mathbf{2 0 0 4 - 2 0 0 6}$ & 7 & 4 & 2 & - & 9 & 8 & - & 30 \\
\hline $\mathbf{2 0 0 7 - 2 0 0 9}$ & 13 & 3 & - & - & 16 & - & - & 32 \\
\hline $\mathbf{2 0 1 0 - 2 0 1 2}$ & 20 & - & - & - & 17 & - & - & 37 \\
\hline $\mathbf{2 0 1 3 - 2 0 1 5}$ & 20 & 1 & - & 1 & 18 & - & - & 40 \\
\hline $\mathbf{2 0 1 6 - 2 0 1 8}$ & 26 & - & - & - & 24 & - & 7 & 57 \\
\hline $\mathbf{2 0 1 9 - a t u a l}$ & 5 & - & - & - & 0 & - & 2 & 7 \\
\hline Total & 95 & 8 & 12 & 1 & 114 & 8 & 9 & 247 \\
\hline
\end{tabular}

Fonte: Adaptado do currículo lattes da Professor Abel

Percebemos que o Professor Abel apresenta trabalhos científicos publicados em anais de eventos, sejam em formato de resumo expandido, resumo e artigo. Além de publicações, participou como membro da organização de congressos, seminário, dentre outros eventos $(n=17)$. 
Sua trajetória pessoal e profissional foi marcada pelo envolvimento com o esporte e experiências acadêmicas. Suas experiências profissionais ultrapassaram as barreiras do ambiente universitário, apenas mencionadas em sua entrevista, mas não contidas em seu currículo lattes.

\subsection{ASPECTOS ÉTICOS}

O estudo foi submetido ao Comitê de Ética em Pesquisa com Seres Humanos da Associação Educacional Luterana - Bom Jesus/IELUSC, o qual é norteado pela Resolução 466/2012, do Conselho Nacional de Saúde, cumprindo todas as necessidades para garantir o sigilo e integridade dos participantes. Foi aprovado pelo parecer $n^{\circ} 2.275 .650$ (ANEXO B), bem como pela emenda realizada a partir do parecer $n^{\circ} 2.840 .269$ (ANEXO C). Todas as informações coletadas foram utilizadas para fins científicos, sob o domínio apenas da pesquisadora do estudo.

Para tal cumprimento, foi solicitada autorização da universidade, via departamento responsável, e foi entregue aos professores que aceitaram fazer parte do estudo o TCLE (APÊNDICE B), juntamente com informações explicativas sobre a pesquisa. Além disso, foi solicitado também o TCLE (APÊNDICE C) aos estudantes, pois foram gravadas as aulas de que participaram, assegurando que nenhuma imagem será divulgada.

A pesquisa não favoreceu financeiramente os participantes, mas também não os prejudicou, caso ocorresse desistência ao longo do processo de coleta de dados. A investigação respeitou a prática do professor, a partir do afastamento de sala de aula, devido a alguma ocorrência no ato da observação. Também não ocorreu interferência da pesquisadora na aula ministrada. No ato das entrevistas, o professor teve a liberdade de não responder perguntas para as quais não se sentisse confortável, ou que pudesse prejudicá-lo.

\subsection{INSTRUMENTOS E PROCEDIMENTOS DE COLETAS DE DADOS}

\subsubsection{Documentos}

Primeiramente, para identificarmos a trajetória profissional dos professores jovens doutores, analisamos o currículo lattes de cada docente. Nessa análise documental verificamos: formação acadêmica, experiências profissionais, produção do conhecimento, áreas de atuação e linhas de pesquisas em que atuam. Também utilizamos o histórico escolar 
das disciplinas cursadas no curso de graduação e pós-graduação (lato sensu e stricto sensu), a fim de compreender a contribuição curricular na prática pedagógica do docente. O plano de ensino e o cronograma das disciplinas também foram utilizados como subsídio para a observação das aulas e para construção da entrevista semiestruturada.

Justificamos a escolha do procedimento de análise de documento, pois, de acordo com Gil (2009a), essas fontes documentais auxiliam o pesquisador a resgatar informações qualitativas e quantitativas sem proporcionar falhas e equívocos na interpretação. Também se consideram importantes as informações retiradas de documentos, pois não receberam nenhum tratamento científico (OLIVEIRA, 2007). Além disso, as informações coletadas em documentos sofrem influência do pesquisador, apresentando um sentido único (CELLARD, 2008).

\subsubsection{Entrevista}

Foram realizados dois tipos entrevistas, primeiramente empregamos a metodologia de história oral, utilizamos as narrativas dos professores a fim de compreender sua história de vida. Justificamos a utilização dessa técnica, pois possibilita a associação entre acontecimentos da vida pública e da vida privada, além disso, recupera informações que não se encontram em documentos ou registros (DELGADO, 2006). Além de solicitarmos ao professor a narrativa sobre sua história de vida, também foi perguntado sobre a contribuição das disciplinas realizadas ao longo da sua trajetória enquanto estudante para sua atual prática pedagógica.

Em seguida aplicamos a entrevista estruturada, a última etapa realizada, cuja construção aconteceu a partir de perguntas direcionadas, norteadas pelos objetivos propostos no estudo, bem como autores que investigam a docência no Ensino Superior. Também utilizamos como aporte às informações coletadas a partir da análise documental (currículo lattes e plano de ensino), história de vida e observações das aulas (APÊNDICE A).

Dessa forma justificamos a necessidade desse tipo de entrevista ocorrer após as etapas de coleta, pois auxiliam na construção do roteiro da entrevista. Tal procedimento nos possibilitou compreensão de pontos incertos identificados ao longo dessas etapas.

A entrevista é considerada uma técnica de coleta de dados comumente utilizada para se obterem informações nas pesquisas do tipo qualitativa, principalmente quando a problemática contorna a área da psicologia, sociologia, pedagogia, ou seja, nas ciências sociais (THOMAS; NELSON, 2002; MOREIRA; CALEFFE, 2008; GIL, 2009a). Esse 
procedimento de coleta de informações busca averiguação de "fatos"; determinação das opiniões sobre os "fatos"; determinação de sentimentos; descoberta de planos de ação; conduta atual e/ou do passado; e motivos conscientes para opiniões, sentimentos, sistemas ou condutas (MARCONI; LAKATOS, 2010).

As entrevistas foram individuais e de forma presencial, utilizamos as dependências da Universidade participante, no horário e na data disponível pelo docente. Para análise, as entrevistas foram transcritas e enviada aos professores para validação das informações.

\subsubsection{Observação}

Essa etapa ocorreu a partir da observação das aulas, não havendo roteiro de observação a priori, e sim, a posteriori, a fim de organizarmos os dados coletados. Ao analisarmos as gravações dos vídeos e os áudios as informações foram dispostas da seguinte forma: a) parte inicial; b) desenvolvimento; c) avaliação; d) recursos didáticos; e) estratégias de ensino; f) comentários relevantes. Nas descrições foram pontuadas conforme os acontecimentos das aulas, quando necessário foram descritas na integra as falas do professor e/ou estudante, bem como retirada a imagem do vídeo para registro no documento. A preocupação nas descrições não foi no conteúdo abordado pelo docente, e sim, a organização de sua aula e seu desenvolvimento.

Foi utilizado o tipo de observação não participante, pois a pesquisadora atua como espectadora (RICHARDSON, 1999), isto é, neste estudo a pesquisadora apenas assistiu às aulas, sem interferências. Essa técnica de coleta de informação - observação - é utilizada com o objetivo de "[...] analisar, avaliar e examinar relações sociais e/ou interações entre pessoas de um determinado grupo, comunidade e sociedade (cultural, econômica e profissional)" (MATTOS; ROSSETTO JUNIOR; BLECHER, 2004, p. 43). Richardson (1999) sugere a utilização da observação em pesquisas sociais que busca estudar o comportamento de alunos em sala ou a atitude do professor/aluno ou relação professor/aluno, e procura utilizar juntamente com a aplicação de entrevista ou questionário. Assim, mostra-se a relevância desse processo de observação na pesquisa associado à próxima etapa que foi a entrevista.

É importante salientar, todavia, que as aulas observadas foram das disciplinas correspondentes ao documento analisado. A fim de apresentar um caráter homogêneo, as aulas que foram observadas ocorreram em sala de aula, denominadas aulas teóricas, excluindo as aulas práticas acontecidas em laboratórios e ambientes externos (ginásio desportivo, pista de atletismo, sala de dança, quadra, dentre outros). Foram observadas três 
aulas de cada professor, isto é, três períodos diferentes, correspondendo a duas aulas consecutivas. E o foco das filmagens foi apenas no professor, não focalizando os estudantes.

\subsection{PROCEDIMENTO DE COLETA DE DADOS}

Essa primeira parte da coleta da pesquisa foi a partir da análise documental, após a seleção dos participantes, no primeiro semestre de 2017 e atualizada em junho de 2018. Tal procedimento ocorreu a partir da coleta das informações retiradas dos currículos lattes dos docentes selecionados, disponibilizado na Plataforma Lattes do CNPq (http://lattes.cnpq.br/), composto por um sistema de armazenamento dos currículos dos professores e pesquisadores, diretório de instituições e diretório de grupo de pesquisa. Logo, o acesso a esses itens é de domínio público, permitindo a coleta sem solicitar autorização do professor. Esse passo possibilita coletas às informações necessárias para seleção dos participantes e informações sobre a trajetória profissional dos professores, quanto à formação acadêmica e experiência profissional.

Essa segunda etapa da coleta de dados aconteceu apenas no segundo semestre de 2018, pois o quadro de disciplinas se modifica a cada semestre. Entretanto aconteceram mediante aprovação da pesquisa pelo Comitê de Ética em pesquisa com Seres Humanos CEP, seguida da solicitação de autorização da Universidade (ANEXO A), a partir do setor responsável pelos professores de Educação Física investigados.

Após autorização, a pesquisadora entrou em contato com os docentes selecionados, a fim de convidá-los a participar da pesquisa, explicando todos os procedimentos que foram desenvolvidos, cuidados éticos, riscos mínimos e os benefícios. O contato foi, primeiramente, realizado via e-mail, em seguida foi marcada uma reunião individual com cada professor para explicar o funcionamento da pesquisa. Os docentes que aceitaram fazer parte do estudo assinaram o Termo de Consentimento Livre e Esclarecido - TCLE (APÊNDICE B) documento que continha todas as informações da pesquisa, confirmando os riscos e benefícios, além da utilização dos dados para fins científicos.

Depois que os docentes aceitaram fazer parte de forma voluntária e espontânea da pesquisa, foi marcada a primeira entrevista utilizando a metodologia da história oral, buscando compreender a história de vida, conforme a disponibilidade do docente. Nesse dia foi solicitado o envio dos planos de ensino das disciplinas ministradas e o histórico escolar da graduação e pós-graduação via e-mail. A partir desse procedimento, foi possível procederse à análise documental dos planos, permitindo identificar as aulas teóricas descritas no 
cronograma, para providenciar a próxima etapa de coleta. Após esse procedimento, foram marcados os dias e as aulas observadas.

Na primeira aula de observação foi conversado com os estudantes, explicando-se a proposta do estudo e todos os procedimentos que seriam realizados. Em seguida, foi entregue o TCLE (APÊNDICE C) aos estudantes, a fim de autorizar a gravação de vídeo e áudio das aulas.

Por fim, foi realizada a etapa da entrevista semiestrutura, que aconteceu individual e presencialmente, momento em que foi gravado o vídeo e o áudio do diálogo ocorrido entre o professor e a pesquisadora nas dependências da Universidade, no dia e horário de interesse do professor investigado.

\subsection{FORMA DE ANÁLISE DOS RESULTADOS}

A análise de todas as fontes coletadas, entrevista, observações e documentos, foi utilizada a triangulação das informações, uma abordagem multimétodos, que permite trabalhar uma variedade ou combinação de métodos de pesquisa. Normalmente, esse tipo de análise ocorre em combinação de pesquisa qualitativa e quantitativa, ou exclusivamente na qualitativa. Seu objetivo é identificar, explorar e compreender diferentes dimensões das unidades de estudo, contribuindo nas interpretações e conclusões (ROTHBAUER, 2008). Nesse estudo utilizamos análise de triangulação de fontes de dados (documentos, entrevistas e observações), pois auxiliaram na credibilidade dos resultados por evidenciar as informações em diferentes fontes.

Para auxiliar na organização dos resultados e no procedimento de análise dos vídeos e transcrições, foram utilizados os recursos disponibilizados pelo software Qualitative Solutions Research Nvivo 11 (QSR Nvivo). Esse instrumento tecnológico possibilitou o armazenamento das informações coletadas de forma geral, além de separar os dados de acordo com cada categoria e cruzamentos de informações. De acordo com Gil (2009a), programas como esse, Nvivo, não executam a análise, cuja função ainda cabe ao elemento humano, mas contribui na organização das informações, possibilitando maior clareza para tal função. 


\section{CAPíTULO 5 \\ HISTÓRIA DE VIDA DOS PROFESSORES UNIVERSITÁRIOS DE EDUCAÇÃO FÍSICA JOVENS DOUTORES: CONSTRUÇÃO DA IDENTIDADE}

Neste capítulo iremos abordar a história de vida dos professores universitários de Educação Física, que são jovens doutores, descrevendo as trajetórias pessoais e profissionais. A partir desse cenário discutiremos sobre a identidade real encontrada desses professores e sua identidade virtual, isto é, como a sociedade compreende os professores universitários jovens doutores e docentes de Educação Física.

\subsection{A TRAJETÓRIA PESSOAL E PROFISSIONAL}

Os professores universitários de Educação Física jovens doutores nos relataram, a partir de narrativas, sobre suas histórias de vida, nas quais pudemos identificar: a relação do contexto familiar, formação escolar da Educação Básica e no Ensino Superior, suas experiências esportivas dentre outras vivências que marcaram toda a trajetória pessoal. Além disso, também relataram sobre as experiências profissionais, a escolha pela formação inicial, a inserção e vivências na pós-graduação e as áreas de pesquisa atuantes.

A trajetória pessoal dos professores jovens doutores foi marcada por uma infância com vivências em cidades do interior do estado de São Paulo e do Rio Grande do Sul. Eriberto, nasceu na cidade de Jaboticabal, cuja principal economia é a agricultura. Entretanto, a partir da narrativa desse docente, sua identidade social herdada foi construída no espaço universitário, pois seus pais eram veterinários e docentes atuantes no Ensino Superior. Sua infância foi marcada pelas vivências em um clube, cujos docentes da universidade em que seus pais lecionavam eram associados. Assim compreendemos que sua socialização primária esteve marcada de forma significativa a partir do grupo social determinado de docentes universitários e suas famílias.

Tínhamos acesso nesse clube, então ficávamos o dia inteiro lá tinha muitos amigos da mesma idade. Só para entender o que era esse clube: era o clube dos professores da universidade, então "Quem eram sócios?" era os professores da [...] universidade [...], quem frequentava era os filhos dos professores, basicamente nosso ciclo de amizade era os filhos dos professores, quase tudo na mesma idade com a variação de uns cinco anos, uma montoeira de gente com a diferença do mais novo para o mais velho diferença de cinco anos (ERIBERTO). 
Os docentes Larissa, Abel e Felipe, em sua identidade social, estão marcados por um grupo social que carrega fortemente em sua história a disputa de território e de causas justas, principalmente a Revolução de Farroupilha. A base econômica é a agricultura, pecuária e a indústria, sendo que Abel e Felipe obtiveram sua primeira infância no primeiro contexto, pois suas famílias tinham como sustento tal produção, consequentemente, sua primeira identidade social foi sustentada pelas socializações estabelecidas nesse contexto. A cidade de onde advém Larissa está localizada em um polo industrial do estado, mas também não fez menção sobre as atribuições de seus pais e o contexto em que cresceu.

A identidade social herdada por esses três professores traz consigo estigmas referentes ao grupo social pertencente, associado a um estereótipo construído e nutrido pela mídia como: a utilização dos trajes típicos de vestidos longos de chita ou de algodão, bombachas, lenços; um linguajar com expressões grosseiras, duras e densas, mas repletas de singularidade, tornando-se um dialeto desse grupo (bah, tchê, guri, guria, tu etc.); o consumo habitual do chimarrão e suas rodas de conversa. Podemos compreender como um símbolo da população gaúcha, a qual está coberta de estigmatizações atribuídas pelos grupos sociais de diferentes estados brasileiros.

Depois do espaço familiar, a escola é outro espaço que contribui para a construção da identidade social dos indivíduos. Professor Eriberto não faz menção às experiências escolares, a partir de sua histórico escolar de graduação, conseguimos identificar o colégio que frequentava antes da formação inicial, o qual estava integrado à rede privada da cidade de Jaboticabal. Essa fase da Educação Básica vivenciada por Eriberto esteve ofuscada ao longo da sua narrativa, predominando nesse período o envolvimento com a prática esportiva e as experiências no clube de professores.

A Professora Larissa estudou em escola pública até o segundo ano do Ensino Médio, em sua cidade de origem. No último ano da Educação Básica, mudou de cidade e foi morar com sua tia no estado de Santa Catarina, onde realizou o terceiro ano em um colégio privado, na cidade de Florianópolis.

Os professores Felipe e Abel, apresentam uma trajetória pessoal muito semelhante, além dos pais serem agricultores e nasceram em municípios do interior do Rio Grande do Sul, também suas formações na Educação Básica ocorreram em instituições públicas. Ambos iniciaram nas cidades de origem e prosseguiram na cidade de Santa Maria. Entretanto Abel, de primeira a quarta série, estudou em uma escola onde havia apenas uma professora para todas as turmas. Conforme sua narrativa, compreendemos que foi um diferencial marcante na formação de Abel, sendo relevante na construção de sua identidade social e profissional 
Eu me lembro muito das aulas no a espaço escolar, que eu vivenciei muito na primeira série até a quarta série e que eu tinha apenas uma professora, que atendia de primeira à quarta série, mas a professora conseguia, mesmo tendo diferentes níveis de ensino dar aula para todos no mesmo local. Isso me chamava muita atenção. Então fui compreender um pouco melhor o sistema. Eu tento aplicar e eu trouxe de lá, e não sistematizar as coisas muito em caixa (ABEL).

A socialização primária dos professores também se deu a partir do envolvimento esportivo, evidenciado em suas narrativas. Assim identificamos a presença significativa da prática esportiva na construção da identidade social desses professores, consequentemente na identidade profissional.

Os professores Abel, Eriberto e Felipe iniciaram o envolvimento com o esporte na fase escolar, essa aproximação veio pela disciplina de Educação Física e outros espaços para a prática de lazer. Quanto à professora Larissa, ficou evidente em sua narrativa que apenas costumava jogar voleibol de vez em quando.

Eu conheci as práticas de atividade física nas aulas de Educação Física. Eu gostava muito de praticar esportes e durante as aulas de Educação Física eu lembro até hoje que eu tinha o professor dele. Eu recordo esse único professor de Educação Física - ele levou o handebol para nós experiência [...] durante a minha adolescência era o estudo e praticar esporte, fazia outras coisas da vida normal. Eu fiz só da minha Formação Escola Pública. Apesar disso qualidade da escola era razoável, existe uma estrutura para a prática de quadra, materiais... E os professores que tinham uma aproximação com os alunos [...] (ABEL).

[...] minha infância toda a minha adolescência foi sempre envolvida com muito esporte e diferentes esportes. Competitivamente alguns e outros não [...] (ERIBERTO)

Desde a minha infância eu sempre fui bastante ligado às práticas esportivas, movimento que acaba influenciando boa parte das pessoas que buscam a Educação Física. Porque o esporte é o chamariz principal (FELIPE).

A prática esportiva proporcionou aos professores se integrarem ao grupo social aos quais se sentiam pertencentes, incorporando para si uma identidade social no contexto esportivo. Essa identidade esteve relacionada desde atleta amador ao alto rendimento, bem como praticante por lazer. Essa construção ocorreu a partir da articulação entre a transição objetiva e a transição subjetiva, quando o professor praticava o esporte ao longo das aulas de Educação Física, passando como representantes da equipe da escola e equipes externas até atingir um nível mais elevado de desempenho físico. Esse processo fez com que suas identidades sociais construíssem e reconstruíssem a cada fase alcançada. O professor Felipe participou de competições, mas em equipes amadoras, enquanto os docentes Eriberto e Abel de competições estaduais e nacionais. 
Então eu nunca treinei como jogador, eu nunca passei por treinamento sistemático de equipes competitivas de alto nível ou nível... Eu participava de equipes que eventualmente se juntava para treinar e irem em competições. Tínhamos treino semanal e tinha um professor, basicamente, não tinha uma cobrança tão [...] Apesar de eu participar de equipes universitárias, municipais, escolares um pouco diferentes [...] (FELIPE)

Eu competi natação, eu competi... iniciei já perto dos 15 a 16 anos comecei a competir triathlon; pratiquei karatê por alguns anos; pratiquei capoeira. Andei de skate por muitos anos também nesse período da adolescência [...] E competitivamente natação, corrida e depois migrei para o triathlon [...] a minha prática mais voltada para competição foi com os esportes individuais. Recreacionalmente, obviamente joguei muito futebol, tinha um clube que eu frequentava de segunda a segunda que tinha timinhos de futebol e até torneiozinhos [...] É evidente que os [esportes] individuais tem um peso muito maior na minha formação, nos meus conhecimentos e vivências, pois foram neles que eu construir uma identidade de atleta nos esportes individuais. (ERIBERTO).

O handebol foi a minha entrada para o mundo esportivo, até para minha formação como professor de Educação Física. Então eu ingressei quando eu tinha uns 12 anos no handebol escolar, comecei a participar de jogos escolares e eu jogava muito na escola. Depois é ingressei no clube, que tem aqui em Santa Maria, o Clube esportivo chamado Corinthians[...] aonde eu comecei jogar handebol em nível de estado [...]. Eu cheguei a jogar Campeonato Gaúcho, Campeonato Brasileiro, Jogos abertos Brasileiro, Jogos abertos do Rio Grande do Sul... A minha vivência esportiva está muito atrelada a prática do handebol (ABEL).

O esporte é um fenômeno social-cultural que contribuiu para o desenvolvimento de crianças e jovens quanto aos aspectos biopsicossociais. Apesar de haver críticas sobre prática esportiva, principalmente nas aulas de Educação Física, consideramos que a questão problema não é o esporte, e sim a forma como está sendo trabalhado pelos profissionais juntos a essa população, bem como sua divulgação midiática. Em virtude disso, defendemos uma pedagogia esportiva fundamentada em situações problemas, de modo que auxiliem na formação integral das crianças e adolescentes, não apenas nas questões técnicas e táticas, visando à performance.

[...] precisam ultrapassar a esfera da prática motora, sendo parte de um processo de ensino, vivência e aprendizagem que privilegie o ensino de valores e comportamentos, questões históricas e culturais sobre o esporte e as modalidades aprendidas, a discussão sobre a ética no esporte, a influência da mídia, o respeito, entre outros conhecimentos que fazem parte do universo esportivo e contribuem para o aspecto educacional e social da prática esportiva (MACHADO; GALATTI; PAES, 2015, p. 406) .

O esporte proporciona espaços desafiadores às crianças e jovens a partir de diversas situações associadas às relações interpessoais como as intrapessoais. Também os aproximam de sujeitos que compõem diferentes grupos sociais. As experiências atribuídas pela prática 
esportiva contribuem “[...] no processo de socialização e na construção das identidades e das relações sociais, matizadas pelas condições de gênero, idade, etnia e cultura ou nível socioeconômico (GRAÇA, 2013, p. 80).

É perceptível a contribuição do esporte na construção da identidade social dos professores Abel, Felipe e Eriberto, pois essa prática foi a principal motivação para a escolha profissional na Educação Física. Quanto à professora Larissa, o esporte a impulsionou, mas não foi o principal motivo, a docente se interessa pela área biológica: "Eu sempre tive gosto pelo esporte, mas eu sempre gostei mais dessa parte do corpo humano, da ciência, essas disciplinas, como a biologia que me encantavam bastante no ensino médio. Eu sempre acreditei que isso seria importante para educação física não só esporte [...]” (LARISSA).

Quanto à narrativa de Felipe, verificamos que prestou vestibular para Engenharia Ambiental, mas não foi aprovado. Então resolveu tentar para o curso de Educação Física, devido a sua proximidade com a área. O professor alega que seus pais não tinham muito conhecimento, assim não conseguiram contribuir para sua escolha profissional, entretanto existia um ex-brigadiano aposentado que tinha uma escolinha de voleibol em Constantina, considerado um influenciador para realizar a formação inicial em Educação Física.

Nessa mesma perspectiva sobre ausência de conhecimento de seus pais, Larissa considera que a Tia, a qual atuava como professora, contribuiu para sua escolha profissional, entretanto não minimizou o incentivo e a contribuição de seus pais para estudar e buscar uma formação profissional.

a influência maior foi da minha tia que era professora eu morei com ela antes de vim para cá [...] mas principalmente ela, por ser professora e sempre me estimular. Meus pais têm até o ensino fundamental, então... Claro, que sempre falam: "minha filha você tem que estudar!", mas eles sabiam que tinham que estudar, mas não sabiam até onde tinha que estudar (LARISSA).

A partir desse contexto, identificamos que os motivos de escolha profissional dos professores jovens doutores não se distingue das motivações encontradas em estudos com docentes da Educação Básica (FOLLE; NASCIMENTO, 2008; HENRIQUE; COSTA, 2016; MOURA, 2015), treinadores (RODRIGUES, 2014; OLIVEIRA, 2017; BORGES, 2018), estudantes de Educação Física (RAZEIRA et al., 2014; SANTOS; SIMÕES; MOREIRA, 2018) e professores universitários (VARGAS; MOREIRA, 2011; BASEI, 2011; 2012; MOLETTA, 2013) que estão em diferentes fases da carreira. Nesse caso específico, a proximidade com o esporte e o interesse pela área biológica foram os principais chamarizes para a escolha dos professores jovens doutores. 
Encontramos relatos interessantes dos professores Felipe, Eriberto e Abel, nos quais conseguimos identificar a presença expressiva do esporte no sentimento de pertencimento para si, isto é, fazia parte de sua identidade social real. Dessa forma não se enxergando fora do contexto esportivo:

\footnotetext{
Então chegou no primeiro dia de aula, perguntaram: "o porquê você fez a Educação Física?" pessoal tentando explicar, então identificamos, como te falei, a maioria tinha procurado a Educação Física alguma aproximação com a prática esportiva. Eu praticava muito esporte, principalmente amador e competições, principalmente no voleibol. Participei no atletismo pela escola, também disputei bastante em campeonatos amadores de futebol de campo (FELIPE).
}

O curso de Educação Física, era a área que eu queria e tinha interesse, muito mais, por ter conhecido pessoas vinculadas ao esporte. Eu conhecia meus treinadores, meus colegas que jogavam comigo que faziam educação física, eu gostava muito [...] eu não tinha ideia do que eu iria fazer depois, eu não tinha essa ideia, mas fui fazer graduação em Educação Física [...] (ABEL).

E aí eu não tinha dúvida, a dúvida que eu tinha ali era a Educação Física ou Biologia, as duas coisas que me atraíam assim né?! O que eu entrar primeiro eu faço! Então como eu fiz Educação Física eu tenho totalmente certeza que a escolha foi certa, estou totalmente realizado com a profissão com as escolhas que eu fiz [...] opção de fazer bacharel foi consciente e certeira, não tinha dúvida [...] não fiz educação física para dar aula em escola, nunca tive intenção de dar aula na escola [... nunca senti vontade de dar aula de Educação Física na Escola - Zero. Não era isso, eu queria trabalhar com esporte, ser treinador, fisiologista, com esporte de competição ou ir para universidade [...] (ERIBERTO).

Antes da inserção na universidade, Felipe e Eriberto apresentaram experiências profissionais fora do contexto da Educação Física. O primeiro não fez menção às especificidades, enquanto o segundo docente aborda que ficou um ano de serviço obrigatório no exército, em cujo período continuou realizando a prática esportiva.

A trajetória acadêmica dos quatro professores jovens doutores foi alicerçada pela universidade pública de caráter federal e/ou estadual, desde a graduação à pós-graduação. Na graduação, Larissa e Eriberto saíram da sua cidade de origem para realizarem a formação inicial, enquanto Abel e Felipe permaneceram na cidade em que residiam juntamente com seus pais, além disso os dois realizaram o curso na mesma instituição.

Quanto à habilitação dos professores no curso de Educação Física, identificamos, a partir do currículo da graduação, que Eriberto obteve a formação em Bacharelado, Larissa em Licenciatura e Felipe e Abel em Licenciatura Plena. A composição dos componentes curriculares realizados por Eriberto não contempla aspectos pedagógicas a docências, a formação desses jovens doutores esteve centrada em diferentes campos de atuação do profissional, exceto escola. Enquanto dos outros três docentes seus currículos apresentaram disciplinas que abrangeram de forma generalizada os diferentes espaços profissionais na 
Educação Física, incluindo o da escola.

Os currículos da graduação dos docentes Felipe, Abel e Larissa foram analisados, embora neles não haja as ementas das disciplinas, isso nos impossibilitou uma análise mais fidedigna das proximidades com as questões pedagógicas do espaço da docência. Então, a partir da nomenclatura dos componentes curriculares analisados, categorizamo-los conforme o semestre realizado por docente (Quadro 8) e identificamos que, ao longo da formação inicial, obtiveram pelo menos uma disciplina com cunho pedagógico, exceto na última fase do curso. Outro ponto a destacar, os professores Abel e Felipe, além de terem cursado a mesma instituição em anos diferentes, a grade curricular permaneceu a mesma nos anos de 1998 e 2002.

Quadro 8 - Componentes curriculares que contemplam os conhecimentos pedagógicos ao longo da formação inicial dos professores de Educação Física jovens doutores

\begin{tabular}{|c|c|c|c|}
\hline $\begin{array}{l}\text { Docentes } \\
\text { Fases }\end{array}$ & Larissa & Abel & Felipe \\
\hline $1^{\mathrm{a}}$ & $\begin{array}{c}\text { Prática de ensino de } \\
\text { educação física; } \\
\text { Psicologia da Educação } \\
\text { I: O Desenvolvimento da } \\
\text { Criança e do Adolescente }\end{array}$ & $\begin{array}{l}\text { Fundamentos da } \\
\text { educação física I }\end{array}$ & $\begin{array}{l}\text { Fundamentos da } \\
\text { educação física I }\end{array}$ \\
\hline $2^{a}$ & $\begin{array}{l}\text { Psicologia da Educação } \\
\text { II: Aprendizagem }\end{array}$ & $\begin{array}{l}\text { Fundamentos da } \\
\text { educação física II }\end{array}$ & $\begin{array}{l}\text { Fundamentos da } \\
\text { educação física II }\end{array}$ \\
\hline $3^{\mathrm{a}}$ & $\begin{array}{c}\text { Sociologia da Educação } \\
\text { C }\end{array}$ & $\begin{array}{l}\text { Psicologia da educação: } \\
\text { educação física }\end{array}$ & $\begin{array}{c}\text { Psicologia da educação: } \\
\text { educação física }\end{array}$ \\
\hline $4^{a}$ & Didática Geral D & $\begin{array}{c}\text { Estrutura e } \\
\text { funcionamento da } \\
\text { educação básica }\end{array}$ & $\begin{array}{c}\text { Estrutura e } \\
\text { funcionamento da } \\
\text { educação básica }\end{array}$ \\
\hline $5^{\mathrm{a}}$ & $\begin{array}{c}\text { Teoria e Prática na } \\
\text { Educação Física; } \\
\text { Estrutura e } \\
\text { Funcionamento do } \\
\text { Ensino de } 1^{\circ} \text { e } 2^{\circ} \text { Graus I; } \\
\text { Filosofia da Educação }\end{array}$ & Didática & Didática \\
\hline $6^{\mathrm{a}}$ & $\begin{array}{l}\text { Educação Física } \\
\text { Especial; } \\
\text { Fundamentos } \\
\text { Humanísticos da } \\
\text { Educação Física } \\
\end{array}$ & $\begin{array}{l}\text { Didática especial de } \\
\text { educação física; } \\
\text { Organização escola }\end{array}$ & $\begin{array}{l}\text { Didática especial de } \\
\text { educação física; } \\
\text { Organização escola }\end{array}$ \\
\hline $7^{\mathrm{a}}$ & $\begin{array}{c}\text { Prática de Ensino de } \\
\text { Educação Física Escolar } \\
\text { I }\end{array}$ & $\begin{array}{c}\text { Currículo em educação } \\
\text { física; } \\
\text { Prática de ensino de } \\
\text { educação física }\end{array}$ & $\begin{array}{c}\text { Currículo em educação } \\
\text { física; } \\
\text { Prática de ensino de } \\
\text { educação física }\end{array}$ \\
\hline $8^{\mathrm{a}}$ & $\begin{array}{c}\text { Prática de Ensino de } \\
\text { Educação Física Escolar } \\
\text { II }\end{array}$ & - & - \\
\hline $9^{a}$ & - & - & - \\
\hline
\end{tabular}

Fonte: Adaptado do histórico escolar de graduação dos professores Larissa, Abel e Felipe (2019) 
Quanto ao desempenho ao longo dos componentes curriculares, também identificamos, a partir do histórico escolar da graduação, que os quatro jovens doutores apresentaram as seguintes médias finais entre 7,5 e 9,03. A professora Larissa apresentou a média geral mais alta com 9,03, destacando as médias mais altas $(10,0)$ nas disciplinas de Psicologia da Educação II: Aprendizagem; Rítmica; Ginástica Esportiva; Natação I, Natação II, Judô Misto. Estudos individuais em Esportes e na Monografia. O professor Felipe apresentou a média das disciplinas 8,71 e a maior média $(10,0)$ foi nos componentes de biologia e legislação e organização do sistema desportivo nacional. Abel, ao longo do curso, atingiu a média geral 8,36 e as disciplinas em específico foram 10 em fundamentos da Educação Física II e Psicologia da Educação: Educação Física. O professor Eriberto obteve a média de 7,53 e sua maior nota foi na disciplina denominada Trabalho de Formatura com 9,6 .

A partir das informações encontradas, verificamos que, apesar da proximidade que os professores Abel, Felipe e Eriberto apresentavam no esporte, suas maiores médias não foram em disciplinas de caráter esportivo. Já a professora Larissa apresentava uma participação mais restrita, como participação em lazer, apresentou um bom desempenho nas disciplinas esportivas de cunho pedagógico e científico. Além disso, a melhor média em natação I e II pode estar relacionada ao conhecimento adquirido na formação informal antes da inserção na faculdade: "[...] de modo geral eu sempre gostei muito de esporte mais os esportes individuais, às vezes, jogava um voleizinho, mas gostava mesmo era de nadar, era o esporte que eu mais gostava" (LARISSA).

Como sabemos as universidades são norteadas pelo tripé - pesquisa, ensino e extensão - considerando o caso das IES públicas o incentivo ao fomento à pesquisa e extensão é considerando mais evidente que as instituições particulares. Nessas universidades públicas apresentaram grupos de pesquisa de referência no país e no mundo, os quais proporcionam os estudantes da graduação essa experiência logo após ao seu ingresso no Ensino Superior.

A disponibilidade de bolsa de fomento à pesquisa, ensino e extensão também se sobressai, pois na universidade há estrutura para concorrer a subsídios financeiros aos órgãos de fomento, diferentemente das instituições particulares, faculdades e centros universitários. Esse contexto com diferentes oportunidades com espaço de formação contribui de forma significativa para a construção da identidade social e profissional dos estudantes. Os diferentes espaços de socialização podem ser desenvolvidos em laboratórios de pesquisas, projetos sociais junto à comunidade via ações de extensão e monitoria nos componentes 
curriculares da graduação, assim o aproximando à docência universitária.

Ao longo da trajetória da graduação, percebemos que as experiências com o tripé balizador da universidade se fizeram presentes na formação dos jovens doutores, bem como nas experiências fora da universidade na área da Educação Física e na prática esportiva. Além disso, identificamos uma influência significativa no profissional em que o docente se tornou hoje, compreendendo que essas experiências foram fundamentais para a construção da identidade profissional apresentada pelos professores jovens doutores. O Quadro 9 retrata as experiências dos professores nos contextos supracitados.

Quadro 9-Experiências em pesquisa, ensino, extensão e espaços fora da universidade ao longo da graduação

\begin{tabular}{|c|c|c|c|c|}
\hline $\begin{array}{l}\text { Professores } \\
\text { Categoria } \\
\end{array}$ & Abel & Larissa & Felipe & Eriberto \\
\hline Ensino & - & $\begin{array}{l}\text { Monitoria no C.C } \\
\text { Judô; } \\
\text { Monitoria no C.C } \\
\text { Teoria e } \\
\text { Metodologia do } \\
\text { Condicionamento } \\
\text { Físico }\end{array}$ & $\begin{array}{l}\text { Monitoria no C.C } \\
\text { Esporte Individual } \\
\text { II" (Atletismo). }\end{array}$ & - \\
\hline Pesquisa & $\begin{array}{l}\text { Iniciação científica } \\
\text { em um grupo de } \\
\text { medidas e } \\
\text { avaliação na } \\
\text { Educação Física }\end{array}$ & $\begin{array}{l}\text { Grupo de Estudos } \\
\text { Monitores } \\
\text { Associados } \\
\text { (Adaptações } \\
\text { Orgânicas ao } \\
\text { Exercício); } \\
\text { Integrante do } \\
\text { Projeto de Pesquisa } \\
\text { - A relação entre a } \\
\text { proporcionalidade } \\
\text { corporal do judoca } \\
\text { e a sua técnica de } \\
\text { preferência }\end{array}$ & $\begin{array}{l}\text { Estágio realizado no } \\
\text { Laboratório de } \\
\text { Biomecânica - } \\
\text { Iniciação Científica }\end{array}$ & $\begin{array}{c}\text { Iniciação } \\
\text { Científica no } \\
\text { laboratório de } \\
\text { Fisiologia do } \\
\text { Exercício }\end{array}$ \\
\hline Extensão & $\begin{array}{c}\text { Projeto de gestão } \\
\text { esportiva; } \\
\text { Projeto sobre a } \\
\text { iniciação esportiva }\end{array}$ & $\begin{array}{l}\text { Programa de } \\
\text { Prevenção e } \\
\text { Reabilitação } \\
\text { Cardio- } \\
\text { respiratório; } \\
\text { P.E de } \\
\text { Condicionamento } \\
\text { Físico }\end{array}$ & $\begin{array}{c}\text { P.E - "UPRS em } \\
\text { movimento - projeto } \\
\text { de musculação"; } \\
\text { P.E - "Atletismo na } \\
\text { Escola: Uma } \\
\text { Possibilidade de } \\
\text { Ensino"; } \\
\text { P.E - Atletismo no } \\
\text { bairro Perpétuo } \\
\text { Socorro }\end{array}$ & - \\
\hline $\begin{array}{c}\text { Demais } \\
\text { Experiências }\end{array}$ & $\begin{array}{c}\text { Árbitro de } \\
\text { handebol e futebol; } \\
\text { Trabalho na gestão } \\
\text { da federação } \\
\text { gaúcha de } \\
\text { handebol - FGHb; } \\
\text { Atleta de Handebol }\end{array}$ & Prática do Judô & $\begin{array}{c}\text { Bolsista do } \\
\text { programa "Segundo } \\
\text { Tempo"; } \\
\text { Atleta universitário } \\
\text { de Voleibol }\end{array}$ & Atleta Triátlon \\
\hline
\end{tabular}

Fonte: Elaborado pela pesquisadora a partir do Currículo Lattes e Entrevistas com os professores (2019)

C.C - Componente Curricular

P.E - Projeto de Extensão 
Ao analisarmos este quadro, identificamos que a socialização no contexto científico, a partir de grupos de pesquisa, bem como participações em congressos auxiliaram na constituição da identidade profissional dos professores jovens doutores. O esporte novamente se fez presente nesse processo, pois esteve atrelado aos projetos de pesquisa e extensão, monitorias e experiências externas a universidades vivenciados ao longo da graduação. Os professores Eriberto, Abel e Felipe já traziam em sua identidade uma estreita relação com o esporte, dando continuidade na graduação. No entanto foi na graduação que a professora Larissa apresentou essa proximidade com o esporte de forma significativa, a qual contribuiu para o caminho profissional seguido e pelo seu emprego de hoje.

\begin{abstract}
Então vou colocar algumas coisas da minha graduação que foram relevantes e que me ajudaram a passar no concurso e atuar como docente: foi fundamental talvez durante a graduação ter conhecido o judô. Apesar de não ter sido atleta. E não ter envolvimento no judô eu fui monitorada [...]. E isso no início foi bem difícil [...]. Fui me graduando de faixa, fui gostando do esporte então comecei a estudá-lo. Na graduação, eu fiz o meu TCC e no mestrado continuei trabalhando com o judô, mas relacionada à atividade física e biomecânica [...] mais relacionado ao desempenho. Eu também continuei no doutorado. E hoje eu continuo na pósgraduação e eu tenho alunos que estudam essa temática (LARISSA).
\end{abstract}

Os professores jovens doutores iniciaram suas participações em eventos científicos e produções acadêmicas a partir do segundo ano em diante da graduação. Identificamos que Abel participou de oito eventos no período de 1999-2002 e apresentou cinco resumos publicações em anais de congressos; Felipe também, oito participações, mas no período de 2002-2005 obteve 14 produções, dentre elas artigo $(n=1)$, trabalhos completos $(n=2)$, resumos expandidos $(n=2)$ e resumos publicações em anais de congressos $(n=10)$; Larissa participou de sete eventos entre 2004-2006 e obteve a produção de um artigo e oito resumos em anais de eventos, totalizando nove publicações; e Eriberto compareceu em um evento no ano de 1997, enquanto suas produções foram maiores, obteve um trabalho completo e nove resumos publicações em anais de eventos.

Também analisamos que Abel e Larissa se envolveram em participações de eventos como membros da organização. O primeiro docente colaborou em cinco eventos nas categorias de congressos e festivais (1999-2001), enquanto a segunda professora contribuiu no desenvolvimento de dois eventos da categoria festival (2003-2005).

Assim compreendemos que a identidade docente foi iniciada pelos professores Larissa, Felipe e Abel ao longo da graduação, considerando que os aspectos pedagógicos não eram conhecimentos novos quando assumiram o Ensino Superior. Quanto ao professor Eriberto, a docência foi despertada antes de ingressar na graduação, devido à socialização 
primária no contexto família, principalmente, em relação a sua mãe. Essa identificação já estava direcionada ao Ensino Superior, pois a rotina vivida pela sua mãe o encantou. Naquele período de escolha profissional reconhecia-se a docência universitária como espaço profissional, diferente da Educação Básica.

[...] fui fazer bacharel e não tinha dúvida do que eu queria, eu não queria dar aula e escola por exemplo. Não fiz educação física para dar aula em escola, nunca tive intenção de dar aula na escola. Na universidade sim, queria formar professor e não dar aula em escola [...] A minha opção era ir para universidade e isso despertou com a minha mãe, eu perguntava: "como tem profissionais de educação física? Se tem, tem gente que dá aula para eles? Existe isso? Mãe se tem isso na sua profissão tem na Educação Física?" E ela dizia que sim, eu lembro claramente dessa conversa com a minha mãe, era isso que eu quero fazer o que você faz, mas na Educação Física. E se não desse certo por algum motivo eu trabalharia com esporte certamente, preparador físico etc. Que foi uma área de atuação minha por algum tempo (ERIBERTO).

Também consideramos que os conhecimentos que contemplam a docência no Ensino Superior foram adquiridos em outras esferas, ao longo da graduação o envolvimento com a pesquisa, extensão e a monitoria dos componentes curriculares, até mesmo a organização de eventos acadêmicos-científicos. Nesse período predominaram as formações complementares em detrimento dos outros períodos como estudante e profissional, as quais também contribuíram para a construção de seus conhecimentos, consequentemente, da sua identidade profissional.

Os professores Abel e Felipe, ao finalizarem a graduação, iniciaram a pós-graduação lato sensu, na própria universidade em que fizeram na graduação. O primeiro docente desenvolveu, no ano de 2003 e 2004, o curso em Pesquisa e Ensino em Ciência do Movimento Humano. Nessa formação obteve conhecimento na área de estatística, introdução à ciência do movimento humano, computação, metodologia de pesquisa, introdução e pesquisa em fisiologia do exercício, teorias e métodos de ensino. Ao longo do curso alcançou nota máxima em todas as disciplinas, totalizando 420 horas de formação. Nesse período também atuou como preparador físico da equipe adulta na modalidade handebol em uma universidade luterana localizada no estado do Rio Grande do Sul.

O segundo professor realizou a especialização em Atividade Física e Desempenho Motor e Saúde entre 2006-2007. Seu curso foi de 360 horas com as disciplinas em avaliação do movimento humano, estudos dirigidos em atividade física, desempenho motor e saúde, estatística e metodologia da pesquisa e elaboração do artigo. Sua monografia esteve associada aos níveis de lactato sanguíneo e comportamento cinemático de crianças que realizaram provas de 50 e $100 \mathrm{~m}$ rasos. 
A pós-graduação stricto sensu de nível mestrado de Felipe, Abel e Larissa ocorreram na mesma instituição, na qual são concursados, UPC, e na área da Educação Física. Enquanto Quanto a Eriberto, ao terminar a graduação, ingressou no mestrado na mesma IES em que estudava no estado de São Paulo e seu curso estava relacionado a Ciências da Motricidade. Nesse período, o que se assemelha e difere entre os professores foi que Felipe e Abel mudaram de estado e cidade para realizar essa formação, mas Larissa e Eriberto deram continuidade na formação com seus mesmos orientadores da graduação.

Na época os programas [...] aqui em Florianópolis, estavam atraindo alguns alunos de lá para fazer mestrado aqui [...] em 2006 foram os primeiros ingressos no mestrado na área de biodinâmica, antes existia de atividade física e saúde e teoria e prática. Em 2006 abriram mais na área do esporte, e era o que eu me dedicava mais. E vieram alguns alunos para cá, abriram as portas, eu vim fazer a seleção e fui aprovado [...] época chamava cineantropometria e desenvolvimento humano, hoje se chama Biodinâmica do Movimento (FELIPE).

Esse período de mudança contribui para a (re)construção da identidade social e profissional do professor Eriberto, pois mudou para uma cidade em que não possuía amigos e não conhecia os docentes da instituição, ou seja, veio para um contexto totalmente novo. Assim o próprio docente reconhece sua "evolução" nessa mudança, principalmente em sua autonomia.

[...] final de 2003 eu passei no mestrado em Santa Catarina [...]. Não conhecia nada aqui e nem ninguém, então, tentei o processo seletivo, e passei na segunda tentativa. Tentei a primeira vez não passei, passei no segundo ano. Fiz meu mestrado na área de atividade física e saúde. Eu não conhecia muito sobre atividade física e saúde eu sempre trabalhei na área de esportes, mas por vivenciar o esporte eu entendia que o esporte era um meio muito difícil para implementar algumas coisas, pelos próprios interesses que existiam, me desiludi um pouco sobre essas questões do esporte, pois entendia como é que as coisas acontecem. foi um momento muito importante para mim, pois eu vi outras coisas, foi um outro ponto muito importante, eu sai do meu mundo comum, que eu estava acostumado: com os professores e colegas, se eu tivesse feito mestrado lá não teria evoluído "como eu acho que eu evolui" - saindo [...] (ABEL).

Além dessa mudança de espaços de convívio, Abel passou por uma transação subjetiva de ruptura, a identidade projetada estava mudando, devido a uma desilusão com o esporte. Apesar do reconhecimento adquirido enquanto profissional e seu desenvolvimento enquanto árbitro de futebol, sua identidade estava ameaçada, não conseguia mais se enxergar naquele espaço. Então, no mestrado, ingressou na área de concentração de Atividade Física Relacionada à Saúde, na linha de pesquisa Cineantropometria e Desempenho Humano, desvinculando-se à pesquisa na área esportiva. 
Quanto aos demais professores, apresentaram uma transação subjetiva de continuidade e transação objetiva de reconhecimento, ocorrendo uma progressão visada, reconhecida e estimulada. Os professores Eriberto e Larissa, permaneceram na mesma área de pesquisa que a da graduação e com o mesmo orientador, assim ocorrendo uma continuação da graduação. Felipe, apesar da mudança de cidade, permaneceu na área de pesquisa de interesse relacionada ao esporte.

Os docentes Felipe e Larissa apresentavam envolvimento em esportes diferentes, o primeiro, voleibol e atletismo, e o segundo judô, mas ingressaram no mestrado na mesma área de concentração, linha de pesquisa e professor orientador (área de concentração Cineantropometria e Desempenho Humano - e da linha de pesquisa - Interação Exercício Físico, Aptidão Física e Desempenho no Esporte). Já o professor Eriberto optou pela área de concentração de Motricidade Humana, permanecendo com estudos na área esportiva.

No período de mestrado, os professores Felipe, Larissa e Abel cursaram no mesmo programa de pós-graduação, assim obtiveram uma formação semelhante, principalmente nas disciplinas cursadas. Enquanto Eriberto, obteve um foco diferenciado, a instituição era diferente e o seu programa estava voltado à área de Motricidade Humana, diferente dos demais professores, cuja área estava diretamente ligada à Educação Física. Conforme mostra o Quadro 10, podemos identificar as disciplinas cursadas nesse período de formação.

Quadro 10 - Disciplinas realizadas ao longo do Mestrado

\begin{tabular}{|c|c|c|}
\hline Disciplinas & Docentes & Conceito \\
\hline \multirow{2}{*}{ Bioestatística } & Larissa & $\mathrm{A}$ \\
\cline { 2 - 3 } & Felipe & $\mathrm{A}$ \\
\cline { 2 - 3 } & Abel & $\mathrm{A}$ \\
\hline Tópicos Especiais: Estatística paramétrica aplicada à motricidade & Eriberto & $\mathrm{B}$ \\
\hline \multirow{2}{*}{ Seminário Avançado em Bioestatística } & Larissa & $\mathrm{A}$ \\
\cline { 2 - 3 } & Felipe & $\mathrm{A}$ \\
\hline Seminário Avançado em Bioestatística à Cineantropometria e & \multirow{2}{*}{ Felipe } & $\mathrm{A}$ \\
\hline \multirow{2}{*}{ Estudos Individuais e Prática de Pesquisa } & Larissa & $\mathrm{A}$ \\
\hline \multirow{2}{*}{ Metodologia da Pesquisa em Educação Física } & Felipe & $\mathrm{A}$ \\
\cline { 2 - 3 } & Abel & $\mathrm{A}$ \\
\hline \multirow{2}{*}{ Produção e Veiculação do Conhecimento em Educação Física } & Larissa & $\mathrm{A}$ \\
\cline { 2 - 3 } & Felipe & $\mathrm{A}$ \\
\cline { 2 - 3 } & Abel & $\mathrm{A}$ \\
\hline Seminário Avançado em Avaliação Fisiológica da Performance & Felipe & $\mathrm{A}$ \\
\cline { 2 - 3 } & Larissa & $\mathrm{B}$ \\
\hline Humana & Abel & $\mathrm{A}$ \\
\hline & Larissa & $\mathrm{A}$ \\
\hline
\end{tabular}




\begin{tabular}{|c|c|c|}
\hline Aspectos Fisiológicos da Motricidade Humana & Eriberto & A \\
\hline \multirow{2}{*}{ Seminário Avançado em Fisiologia e Bioquímica do Exercício } & Larissa & A \\
\cline { 2 - 3 } & Felipe & A \\
\hline Tópicos Especiais em Fisiologia Experimental & Eriberto & A \\
\hline Aspectos Fisiológicos da Nutrição no Exercício & Eriberto & A \\
\hline Aspectos Metabólicos do Diagnóstico do Rendimento Físico & Eriberto & A \\
\hline Seminário Avançado em Atividade Física e Saúde: Aspectos & \multirow{2}{*}{ Abel } & A \\
\hline \multirow{2}{*}{ Cineantropometria } & Felipe & A \\
\cline { 2 - 3 } Biomecânica Ocupacional & Abel & A \\
\hline \multirow{2}{*}{ Fundamentos da Motricidade Humana } & Larissa & A \\
\cline { 2 - 3 } & Felipe & \\
\hline Atividade Física, Saúde e Qualidade de Vida & Eriberto & A \\
\hline \multirow{2}{*}{ Didática no Ensino Superior } & Abel & A \\
\hline Formação e Desenvolvimento Profissional & Larissa & A \\
\cline { 2 - 3 } & Felipe & A \\
\cline { 2 - 3 } & Abel & A \\
\hline Bases Epistemológicas da Educação Física & Eriberto & A \\
\hline
\end{tabular}

Fonte: Adaptações do histórico escolar do mestrado dos professores de Educação Física jovens doutores (2019)

Ao analisarmos o quadro das disciplinas, identificamos que todos os professores realizaram disciplinas relacionadas à área de pesquisa quantitativa, pois foi evidente um ou mais componentes cursados na área da estatística. Ainda verificamos que produção do conhecimento, as questões científicas e as disciplinas específicas da área de concentração estiveram mais presentes em detrimento das disciplinas de cunho pedagógico. A importância desses componentes pedagógicos foi reconhecida pelos professores para sua formação enquanto docentes do Ensino Superior.

Também observamos que o professor Abel frequentou mais disciplinas que o aproximou dos conhecimentos pedagógicos ao longo do mestrado, pois cursou dois semestres de estágio de docência, considerando que Felipe e Larissa fizeram apenas um. Além disso, realizou a disciplina de Formação e Desenvolvimento Profissional, a qual contextualiza a docência como um todo e as funções atribuídas aos docentes do Ensino Superior. O componente Bases Epistemológicas da Educação Física certamente auxiliou a refletir sobre as questões das concepções atuais e organização disciplinar das principais abordagens da Educação Física. 
na escola: nas séries iniciais e ensino fundamental, para oitava série que eu fiz. Mas com crianças e jovens, na escola. Fora os projetos de extensão sobre ensino do esporte, mas no Ensino Superior foi o estágio de docência e foi bem importante também, pois isso me deu suporte bastante para prática docente depois (FELIPE).

Durante minha a pós-graduação, as disciplinas foram bem importantes, pois como eu entrei direto. Então, eu não fiz uma especialização. A Bioestatística foi muito importante; Metodologia de Pesquisa, ou seja, disciplinas mais básicas, na época [...] é o estágio de docência também foi importante no mestrado porque logo em seguida conseguir um emprego. Isso ajudou porque fato de dar aula (LARISSA)

A disciplina [...] fisiologia experimental [...] foi muito rica, em ponto de vista de conteúdo e de ver coisas que são muito abstratas, quando falamos de corpo humano e funções que não conseguimos ver [...] ajudou muito a construir um conhecimento, permitindo sair um pouco da teoria somente e pegar um pouco na prática [...] cursei uma disciplina que achei bem interessante, que era Didática no Ensino [...] no curso de Pedagogia, era optativa [...] mas eu quis fazer, realmente, achava que seria interessante na época, importante para minha formação. Foi uma disciplina muito interessante e muito boa, no ponto de vista de formação para o ensino superior, nos cursos de graduação de forma geral (ERIBERTO)

Os docentes, ao longo do mestrado, receberam bolsa de fomento à pesquisa pela Capes ou CNPq. Felipe e Eriberto iniciaram a docência nesse período em IES de cunho privado, ambos para atuar em disciplinas com contexto esportivo. "Eu tinha duas horas, eu acho, só duas horas aulas na disciplina de Treinamento esportivo. Então comecei dar aula ainda no mestrado [...]" (ERIBERTO).

Na metade do mestrado.... primeira parte do mestrado eu não tinha não tinha bolsa, então eu participei de alguns projetos para ganhar bolsa, então trabalhava em projetos de extensão aqui no centro. No segundo ano do mestrado ganhei bolsa do programa, naquela época era difícil porque eu tinha poucas [...] mas eu permaneci muito pouco com a bolsa, pois eu recebi uma proposta de emprego [...] eu tinha contato com atletismo e o professor de atletismo da UNISUL foi embora [...] então resolvi ir, e foi uma decisão bem acertada, pois eu permaneci mais quatro anos depois na instituição. Lá eu trabalhei com atletismo e voleibol [...] (FELIPE)

Ao longo desse período de mestrado os docentes também se envolveram com publicações, participações em eventos e formação complementar (Gráfico 6). A partir desse contexto podemos afirmar que os professores estiveram preocupados com a produção e construção de seu conhecimento, os quais transcenderam as obrigações curriculares do mestrado (disciplinas, estágio de docência e dissertação). As publicações em eventos e periódicos se destacaram em todos os docentes, mas Abel também apresentou preocupação com a formação complementar, em detrimento dos demais professores. 
Gráfico 6 - Construção e produção do conhecimento ao longo do mestrado

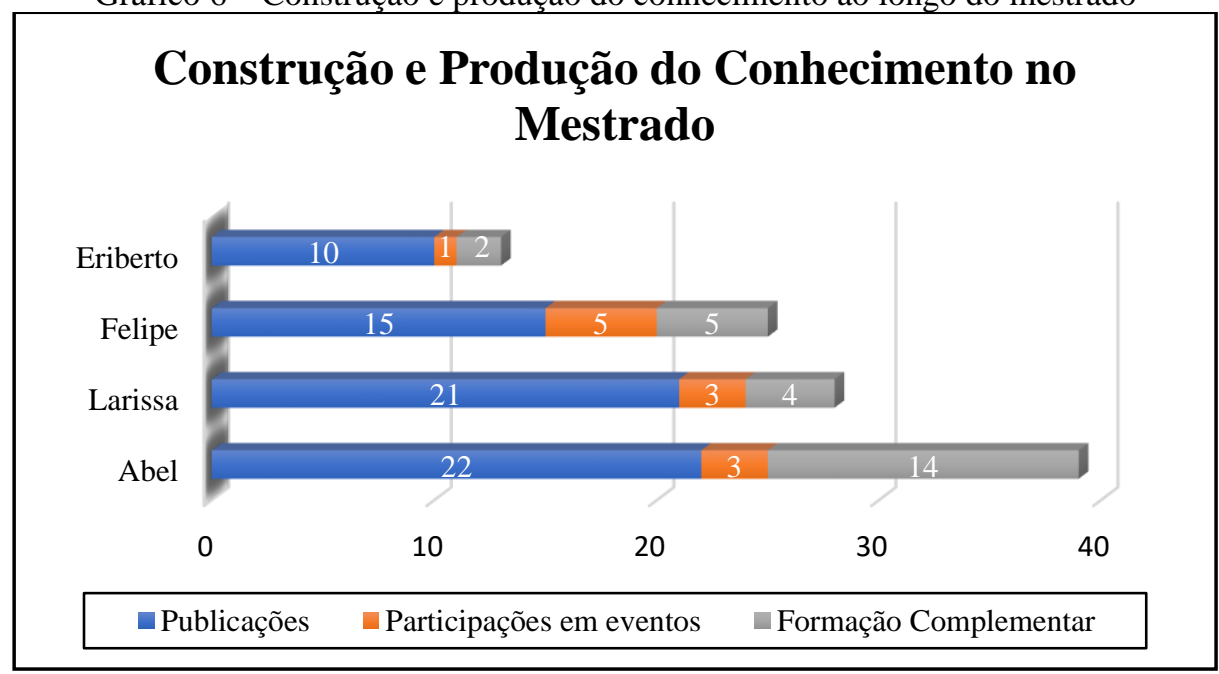

Fonte: Adaptações dos currículos lattes dos professores de Educação Física jovens doutores (2019)

A diferença de quantidade desses envolvimentos, do professor Eriberto para com os demais professores, consideramos que há relação com o período histórico em que foi realizado o mestrado. $\mathrm{O}$ distanciamento do ano de ingresso no mestrado de Eriberto para Abel foi menor, cinco anos, enquanto de Felipe foram oito anos e Larissa ocorreu uma década depois. Conforme evidenciado no capítulo 2, fundamentado em Kokubun (2006), os programas de pós-graduação em Educação Física no país se igualaram aos demais cursos no período de 1996-2000, período em que o professor Eriberto realizou seu mestrado (19982000).

Ao finalizarem o mestrado, todos os jovens doutores ingressaram e/ou permaneceram como professores do Ensino Superior, assim constando como primeira experiência na docência profissional universitária. Eriberto e Felipe permaneceram nas instituições particulares em que estavam atuando ao longo do mestrado, ampliando a carga horária, isto é, assumindo mais disciplinas para ministrarem. Larissa começou a atuar em uma universidade no Vale do Itajaí, Estado de Santa Catarina, permanecendo um ano e meio. Abel foi aprovado no processo seletivo para uma universidade pública no estado do Paraná, onde também permaneceu aproximadamente um ano e meio, mudando-se para outra IES pública no mesmo estado em que atuou nove anos.

Foi legal, foi minha primeira experiência na docência autônoma que eu tinha realmente. E foi muito bom porque era uma área que eu dominava, principalmente as questões técnicas, era mais tranquilo, eu só tinha que me preocupar com as questões pedagógicas, para organizar tudo isso (ABEL).

A primeira experiência docente de Abel também esteve relacionada à prática 
esportiva, ao ingressar como professor da instituição e assumir 20 horas de handebol. Assim voltou a se aproximar do contexto esportivo, motivo que o afastou do mestrado. Em contrapartida, a professora Larissa se afastou um pouco do esporte ao assumir a docência, pois as disciplinas em que atuou estiveram relacionadas à cineantropometria, trabalho de conclusão de curso e biomecânica. Logicamente, não se afastou da área de pesquisa na qual atuava, apenas descentralizou-se do esporte.

O professor Abel, ao mudar de instituição, acabou se afastando novamente do esporte, pois o processo seletivo estava relacionado à área de formação do mestrado - Atividade Física e Saúde - mas acabou assumindo outras disciplinas de diferentes áreas de conhecimento. $\mathrm{O}$ docente alega que essa transição entre os componentes curriculares estava imbricada na política do curso, não queria professores especialistas, e sim generalistas. Entretanto reconhece que esse envolvimento em diferentes disciplinas contribuiu para a construção do seu conhecimento e para sua prática profissional.

Segundo narra o professor Abel, a instituição apresentava uma história relativamente longa, estava centrada ao ensino, ainda se estruturando a pesquisa e extensão. Os estudantes, em geral, apresentavam uma perspectiva de formação técnica, voltada para atuação profissional, e não intelectual, visando a uma pós-graduação. Esse contexto levou o docente ao "choque com a realidade", pois as instituições em que transitou apresentavam essas questões consolidadas. Dessa forma Abel precisou se adequar à realidade vivida e iniciou aplicação dos conhecimentos e experiências adquiridas até o momento naquela instituição que carecia de um espaço em pesquisa e extensão, mas respeitando as necessidades e interesses do local.

Para mim foi um choque, eu saí de nível de excelência [...], que tinha um nível de pós-graduação bom. E fui para um nível que não tinha nada, pode ser os professores não queiram isso, tudo o que você inventava, por exemplo, criar um grupo de estudo, as pessoas não entendiam direito: para que um grupo de estudos? Você vem dá aula e depois vai para casa [...] esse choque foi muito grande para mim. Eu tive que aos poucos montando um grupo de estudos, fui me organizando a partir do interesse dos alunos tinham, não os meus interesses, pois os meus interesses estavam meio distantes da realidade que tinha lá. Eles estavam interessados em obesidade, tinham interesse mais locais [...] (ABEL).

O professor Eriberto, após o término do mestrado, mudou-se para o interior de Minas Gerais e expandiu sua atuação profissional, fez sociedade com seu colega de empresa de ecoturismo, promovendo esportes de aventura. O docente viajava semanalmente para Franca, onde lecionava na IES em que já atuava anteriormente. Entre 2007 e 2008 também atuou como preparador físico da Associação Franca de Voleibol. Nesse período iniciou a 
inquietação para continuar sua formação acadêmica, então entrou em contato com seu orientador do mestrado, o qual estava se credenciando no programa de pós-graduação da UPC.

\begin{abstract}
por volta de 2005/2006 eu comecei a sentir vontade de fazer o doutorado, realmente a carreira acadêmica. Procurei meu orientador né?! ele estava no processo ali descredenciado o programa que estava em Rio Claro e em 2007 ele falou que possivelmente ele iria se credenciar aqui [UPC], e se eu tinha interesse em fazer o doutorado aqui. Isso foi em 2007 ou 2008! Eu já estava um pouco saturado da vida que eu tinha lá na universidade particular e sociedade que eu tinha já tinha sido desfeita. Eu estava trabalhando sozinho lá na empresa, eu resolvi vim realmente. Não falei nada que me segurava (ERIBERTO).
\end{abstract}

Percebemos que, embora transite em outros espaços de atuação na área da Educação Física, Eriberto apresentou uma forte relação com o contexto acadêmico, pois viajava toda semana para ministrar aulas na outra cidade e nutria-se de ações de cunho científico e acadêmico: orientação e membro de banca de trabalho de conclusão de curso; realizou pesquisa e publicações; ministrou cursos de curta duração; participou de eventos científicos; elaborou artigos para internet, dentre outras atribuições. Assim compreendemos a relação de pertencimento ao espaço acadêmico, evidenciando que sua identidade profissional está diretamente ligada à docência do Ensino Superior e à pesquisa.

A inserção de Abel e Eriberto no doutorado ocorreu a partir de período mais extenso de atuação profissional, respectivamente quatro e nove anos. Também mudaram de instituição, Abel ingressou em um programa do estado do Paraná e Eriberto com o mesmo orientador do mestrado na UPC. Assim, realizou o doutorado na mesma instituição de Larissa e Felipe, os quais ingressaram no ano seguinte ao finalizar o mestrado, continuando com a mesma orientadora do mestrado e instituição.

Abel relata que ingressou no doutorado via bolsa que o estado do Paraná fornecia aos docentes atuantes em universidades estudais - Fundação Araucária (FA). O professor, egresso do programa de pós-graduação da UPC, estava com vaga e o convidou a realizar o processo seletivo partir desse incentivo. O docente menciona que essa experiência foi importante em sua trajetória profissional, contribuiu na sua formação, além da relação estabelecida com o orientador e seu grupo de pesquisa, também realizou uma parte do doutorado em Portugal, conhecendo outra cultura.

foi muito bom, porque foi outra experiência em outro grupo. Então a diversidade de experiências que eu tive foi a grande riqueza da minha formação. Esse professor tinha uma inserção internacional de pesquisa, era um pesquisador internacional de destaque no Brasil. Tem um grupo de pesquisa muito forte, numa área 
específica de atividade física. Isso me fez avançar bastante, principalmente, na parte técnica área que eu escolhi. Fiquei quatro anos fazendo Doutorado, fiz um período de estágio do doutorado em Portugal, na Universidade do Porto, com as questões de ambiente urbano e saúde, que é o que eu trabalho, políticas públicas de espaço na promoção de atividade física (ABEL).

Nesse período de doutorado, Abel permaneceu com vínculo na universidade em que lecionava, a qual oportunizou o envolvimento na implementação da residência multiprofissional. Também foi outro momento que contribuiu na formação do professor, pois iniciou o trabalho com metodologias ativas, algo novo em sua carreira. "Eu não sabia nada de metodologias ativas, só conhecia por nome, então o processo de saber como que é etc. Então eu tive que ver como é que é coloca na prática do dia a dia dos alunos, foi uma experiência muito rica também” (ABEL).

O professor Eriberto mudou de cidade para cursar o doutorado e realizou o processo seletivo em outra instituição pública no estado de Santa Catarina, onde permaneceu durante toda essa formação e o pós-doutorado (2009-2014). Felipe também atuou como docente enquanto fez o doutorado, aproximadamente dois anos, realizou as disciplinas e pouco se envolveu com o projeto da tese. Após esse período, viu a necessidade de se envolver mais com sua pesquisa, então se desligou da universidade em que lecionava e ficou apenas se dedicando aos seus estudos, recebendo bolsa de estudos. Também reconhece a importância desse período em que esteve atuando como professor para sua formação profissional.

[...] fiquei trabalhando mais dois anos. Nesse período estava muito cheio, então, fiz só as disciplinas básicas do doutorado e não me envolvendo com o projeto. Foi bastante corrido, mas rico, em termos que aprendi bastante coisas e experiências enfim... Passou esse período de dois anos, precisei me envolver mais com o projeto doutorado, pois fui para uma linha mais da biomecânica mais básica, assim... Então, resolvi largar [instituição], foi uma decisão pouco difícil, pois consegui uma bolsa no doutorado, mas eu tinha um emprego. E você sabe, que emprego não temos em qualquer lugar, mas larguei (FELIPE).

A professora Larissa tem uma situação inusitada ao longo do seu doutorado, ingressou em 2011 e no ano de 2013 deparou-se com o edital que abriu para docente na área do judô na UPC, instituição em que estava cursando a pós-graduação. Naquela época surgiu uma lei que possibilitava mestres assumirem disciplinas em instituições pública, essa resolução permaneceu apenas seis meses, e foi nesse período que Larissa entrou como docente com dedicação exclusiva na UPC. A docente considera que foi um período conturbado, pois tinha que escrever sua tese e preparar as aulas, entretanto reconhece a importância do judô nesse processo. Apesar da garantia de emprego, relata que precisou finalizar o doutorado em três 
anos, o que também a impediu de realizar o almejado doutorado sanduíche, e explorar melhor as disciplinas ofertadas pelo programa.

Eu passei em primeiro lugar aqui na [UPC] em 2013. Eu não tinha nem terminado o doutorado ainda. Foi uma loucura, então eu tinha que planejar aula e realizar a minha coleta de dados do doutorado para fazer. Foi o ano mais louco da minha vida. Passou... E graças a esse ano eu tenho emprego hoje [...] algumas coisas da minha graduação que foram relevantes e que me ajudaram a passar no concurso e atuar como docente: foi fundamental talvez durante a graduação ter conhecido o judô (LARISSA).

Durante o doutorado os professores Eriberto, Abel e Larissa não indicaram disciplina que houvesse impactados de forma efetiva na consolidação das práticas pedagógica. A contribuição dessa formação para Larissa foi a partir das discussões com convidados internacionais; Eriberto mudança de instituição, envolvendo outros profissionais e sistema de ensino que o marcou nesse período; e Abel considera que o estágio de docência o auxiliou, mas como possuía experiência como professor não foi tão impactante, porém no doutorado centralizou os conhecimentos associados à pesquisa e métodos científicos.

\footnotetext{
Durante o doutorado, como eu fiz mestrado e doutorado aqui algumas disciplinas eram muito parecidas. Não aproveitei muito, não me recordo de nenhuma disciplina do doutorado que tenha chamado atenção. Talvez aquelas disciplinas de Convidados internacionais (LARISSA)

No Doutorado, te confesso, que não tive nenhuma disciplina que foi voltada... que eu não tenha feito, poderia ter no programa, mas não tenha feito. Fiz o estágio de docência, acho que ajudou bastante, mas [...] eu tinha uma noção do que era dar aula e como era a aula. Então não tive um doutorado com aulas ou formação para dar aula, foi mais focado mais na pesquisa e nos métodos científicos (ABEL).

Aqui no doutorado, não tenho a lembrança de uma disciplina, eu estava numa realidade diferente, foram pessoas diferentes. A graduação e o mestrado eu fiz no mesmo local, então, eu conhecia muito da estrutura, dos professores e dos laboratórios e tudo mais. Quando eu vim para cá era tudo novo, tanto na estrutura física como professores, por si só isso foi interessante, conhecer uma outra realidade, outras pessoas, outras vivências, mas não teria uma disciplina específica que me marcou (ERIBERTO).
}

O professor Felipe apresentou uma perspectiva diferenciada sobre o doutorado, destaca que houve uma disciplina que refletia sobre a prática docente na área do esporte, saúde e na Educação Física, a qual era ministrada por três docentes das respectivas áreas. Também relata que realizou disciplinas de cunho mais técnico e o estágio de docência, essa segunda experiência lhe possibilitou aprofundar os conhecimentos didáticos na área de biomecânica, na qual não estava acostumado a atuar. Ao longo do doutorado se aproximou 
de treinadores e atletas com quem discutia questões pedagógicas, as quais foram identificadas como aspectos que contribuíram para sua formação.

\begin{abstract}
Nesse período do doutorado eu fiz algumas disciplinas bem importante também, por exemplo: disciplina que é obrigatória no doutorado [...] me fazia discutir e refletir bastante sobre a prática docente, como o nome próprio diz: "qual a contribuição de cada área para o esporte, saúde e na Educação Física, qual é a formação do doutor, qual o conhecimento que ele precisa ter, mais específico? Mais geral? qual o Equilibrio?”. Essa disciplina foi importante nesse sentido. Eu fiz disciplinas mais técnicas também. Eu fiz de novo o estágio de docência, que era obrigado a fazer, na disciplina de biomecânica, como estava estudando mais para biomecânica, também foi importante. Pude aprofundar mais os conhecimentos e procedimentos didáticos numa disciplina que não estava tão acostumado, pois estava lidando mais com esporte mesmo [...] (FELIPE).
\end{abstract}

Ao analisarmos o histórico escolar do doutorado dos professores, identificamos que houve disciplinas validadas no período do mestrado, assim o número de componentes cursado foi menor que da formação anterior e o desempenho de todos os professores foi de conceito máximo (Quadro 11). Verificamos também que, os professores Eriberto, Felipe e Larissa, por cursarem a mesma instituição, realizaram as mesmas disciplinas, isso significa que o impacto da disciplina mencionada por Felipe "Educação e Saúde: Contributo da Educação Física" não contribuiu ou até mesmo não foi enxergada da mesma forma por Larissa e Eriberto. No caso do professor Abel, que cursou a disciplina de "Prática Docente no Ensino Superior", como não fez menção sobre ela, consideramos que tal componente esteja relacionado ao estágio de docência, caso contrário também não foi marcante em sua formação.

Quadro 11 - Disciplinas cursadas ao longo do doutorado

\begin{tabular}{|c|c|c|}
\hline Disciplinas & Docentes & Conceito \\
\hline \multirow{3}{*}{ Tópicos Especiais em Cineantropometria e Performance Humana } & Larissa & $\mathrm{A}$ \\
\cline { 2 - 3 } & Felipe & $\mathrm{A}$ \\
\cline { 2 - 3 } & Eriberto & $\mathrm{A}$ \\
\hline Práticas Laboratoriais em Fisiologia do Exercício & $\mathrm{Abel}$ & $\mathrm{A}$ \\
\hline \multirow{3}{*}{ Educação e Saúde: Contributo da Educação Física } & Eriberto & $\mathrm{A}$ \\
\cline { 2 - 3 } & Larissa & $\mathrm{A}$ \\
\cline { 2 - 3 } & Felipe & $\mathrm{A}$ \\
\hline Epidemiologia da Atividade Física & Abel & $\mathrm{A}$ \\
\hline \multirow{3}{*}{ Estudos Individuais e Prática de Pesquisa } & Larissa & $\mathrm{A}$ \\
\cline { 2 - 3 } & Felipe & $\mathrm{A}$ \\
\cline { 2 - 3 } & Eriberto & $\mathrm{A}$ \\
\hline Ritmos Biológicos & Abel & $\mathrm{A}$ \\
\hline \multirow{2}{*}{ Tópicos Especiais em Cineantropometria e Desempenho Humano } & Larissa & $\mathrm{A}$ \\
\cline { 2 - 3 } & Felipe & $\mathrm{A}$ \\
\cline { 2 - 3 } & Eriberto & $\mathrm{A}$ \\
\hline
\end{tabular}




\begin{tabular}{|c|c|c|}
\hline \multirow{2}{*}{ Estágio de Docência } & Felipe & A \\
\cline { 2 - 3 } & Larissa & A \\
\cline { 2 - 3 } & Eriberto & A \\
\hline Prática Docente no Ensino Superior & Abel & A \\
\hline Metodologia da Pesquisa em Educação Física & Eriberto & $\mathrm{A}$ \\
\hline Metodologia da Pesquisa Científica & Abel & $\mathrm{A}$ \\
\hline Tópicos Especiais em Bioestatística & Eriberto & $\mathrm{A}$ \\
\hline Bioestatística & Eriberto & $\mathrm{A}$ \\
\hline Exercício e Esporte na Infância e Adolescência & Abel & $\mathrm{A}$ \\
\hline Treinamento em Competências Psicológicas & Abel & $\mathrm{A}$ \\
\hline Produção de Artigo Científico & Abel & $\mathrm{A}$ \\
\hline
\end{tabular}

Fonte: Adaptação do histórico escolar do doutorado dos professores de Educação Física jovens doutores (2019)

O estágio de docência dos professores Larissa, Felipe e Eriberto foram realizados no curso de Bacharelado em Educação Física na UPC, cuja identificação fizemos a partir do histórico escolar, respectivamente foram: Teoria e Metodologia do Judô no curso de Bacharelado em Educação Física; Biomecânica e Teoria e Metodologia do Treinamento Esportivo; Teoria e Metodologia do Treinamento Esportivo

Se observarmos os quadros de disciplinas realizadas ao longo do mestrado e doutorado, podemos afirmar que os docentes, durante a pós-graduação stricto sensu, apresentaram uma formação acadêmica semelhante. Isso se justifica, pois todos os professores em algum momento da sua trajetória formativa passaram pelo programa da UPC. Ainda vamos além, Abel e Felipe apresentaram aproximações desde a graduação, pois realizaram a formação inicial na mesma instituição. Observamos que, de alguma forma, suas trajetórias se entrelaçam, assim como com a universidade em que atualmente (2019) estão atuando.

A produção do conhecimento entre os docentes Larissa e Felipe iniciou na proximidade do mestrado, em virtude da orientadora ser a mesma e ambos participarem do mesmo grupo de pesquisa. Também identificamos que Abel contribuiu para a formação profissional da professora Larissa, pois foi banca avaliadora do TCC. No doutorado também fizemos o levantamento da construção do conhecimento e das produções intelectuais dos professores (Gráfico 7). 
Gráfico 7 - Construção e Produção do conhecimento ao longo do doutorado

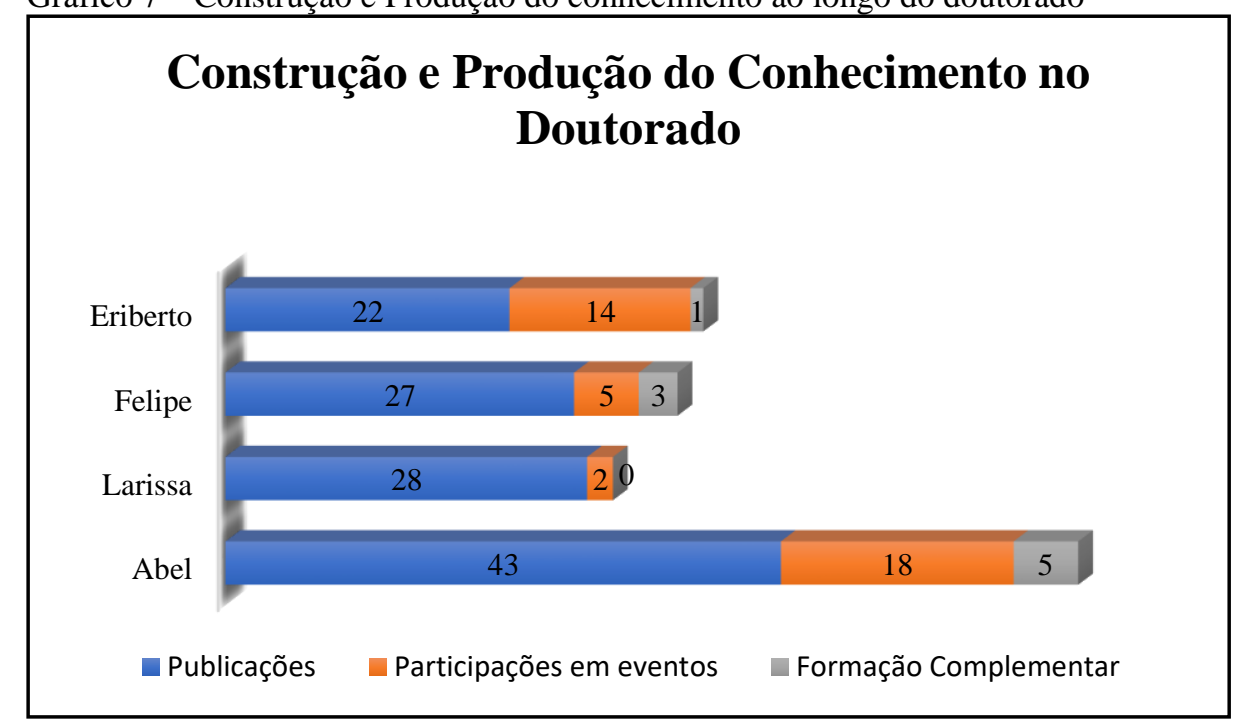

Fonte: Adaptações dos currículos lattes dos professores de Educação Física jovens doutores (2019)

A construção do conhecimento a partir das participações em evento e formação complementar continuam apresentando um olhar secundário em detrimento das publicações intelectuais. Novamente, Abel está mais envolvido nas três categorias analisadas, assim compreendemos que, a partir desse quadro, no doutorado continuou com a busca da construção do conhecimento além das possibilidades dessa formação. Essa perspectiva também apareceu em Eriberto ao participar de 14 eventos. Larissa e Felipe apresentaram uma preocupação mais restrita com a construção do conhecimento, a qual foi centralizada apenas no doutorado.

Como mencionado, Larissa ingressou como docente na UPC enquanto estava cursando o doutorado e permaneceu após seu término. Enquanto os professores Eriberto, Felipe e Abel continuaram lecionando, aproximadamente seis meses a um ano, até ingressarem como professor efetivo da UPC. Eriberto, nesse período, realizou o pósdoutorado na mesma instituição (2013-2014); Abel ficou na mesma instituição no estado do Paraná; e Felipe foi aprovado no processo seletivo na mesma IES em que Eriberto atuava. A partir desse momento as trajetórias dos professores se entrelaçaram (2013-2014).

Sobre o concurso, Felipe relata em sua entrevista que ficou na dúvida para que vaga iria se candidatar, acabou escolhendo a que acreditava ter mais chance de aprovação. Considerou também que as experiências anteriores com o esporte contribuíram para sua aprovação no concurso, perspectiva com que corrobora Larissa ao exaltar a importância do conhecimento sobre o judô para sua aprovação no concurso. 
saiu o concurso aqui na [...] com duas vagas e eu fiquei na dúvida em qual fazer [...] eu fui, talvez, mais pela possibilidade de ser aprovado no concurso mesmo (risadas). E talvez que também pesou mais o tempo de experiência de didática nos esportes. Então fui fazer de esportes, mas o concurso em esporte pegava mais pontos técnicos - de treinamento físico, treinamento técnico-tático, pegava mais pontos elementares sobre formação didática de ensino e pedagogia do esporte, apesar de trabalhar com isso, mas eu não estudava e discutia isso (FELIPE).

Identificamos, a partir da entrevista de história de vida de Abel, dois motivos importantes que o motivou a realizar o concurso para UPC: primeiro relacionado à família e o segundo por reconhecer a qualidade da instituição, almejando como um local que apresentava sua linha de pesquisa e conhecia o grupo de professores. Dessa forma compreendemos que essa escolha esteve relacionada a uma identidade visada, o professor se identificava com o grupo ao qual gostaria de ser pertencente.

Terminei meu doutorado em 2013 no primeiro semestre e abriu concurso na [UPC]. E a escolha de ter vindo para [UPC] foram vários fatores: primeiro, porque universidade é muito boa e tinha estrutura muito boa; segundo, porque eu me casei em 2010 e a minha esposa é daqui de Florianópolis e a família toda dela é daqui, pesou um pouco. Até porque, nós estávamos viajando toda semana para cá, então era o lugar que eu gostaria de trabalhar tinha várias pessoas que eu conhecia, a linha de pesquisa da boa (ABEL).

A trajetória de formação acadêmica dos professores até o momento da efetivação docente na UPC ocorreu em tempos diferentes, o mais próximo foi de Felipe e Larissa no doutorado. As universidades onde se desenvolveram enquanto profissionais em algum momento foram as mesmas. Conforme a Figura 13, identificamos que a formação inicial e a pós-graduação lato sensu de Abel e Felipe ocorreram na mesma instituição (UPRS); ambos foram fazer mestrado na UPC, onde Larissa cursou a graduação e o mestrado; no doutorado Felipe e Larissa permaneceram na UPC e o professor Eriberto também vai realizá-lo no mesmo programa; por fim, todos acabam se encontrando na UPC entre os anos 2013 e 2014, quando são aprovados como professores efetivos nos cursos de Educação Física. 
Figura 13 - Trajetória acadêmica dos professores jovens doutores até efetivação docente

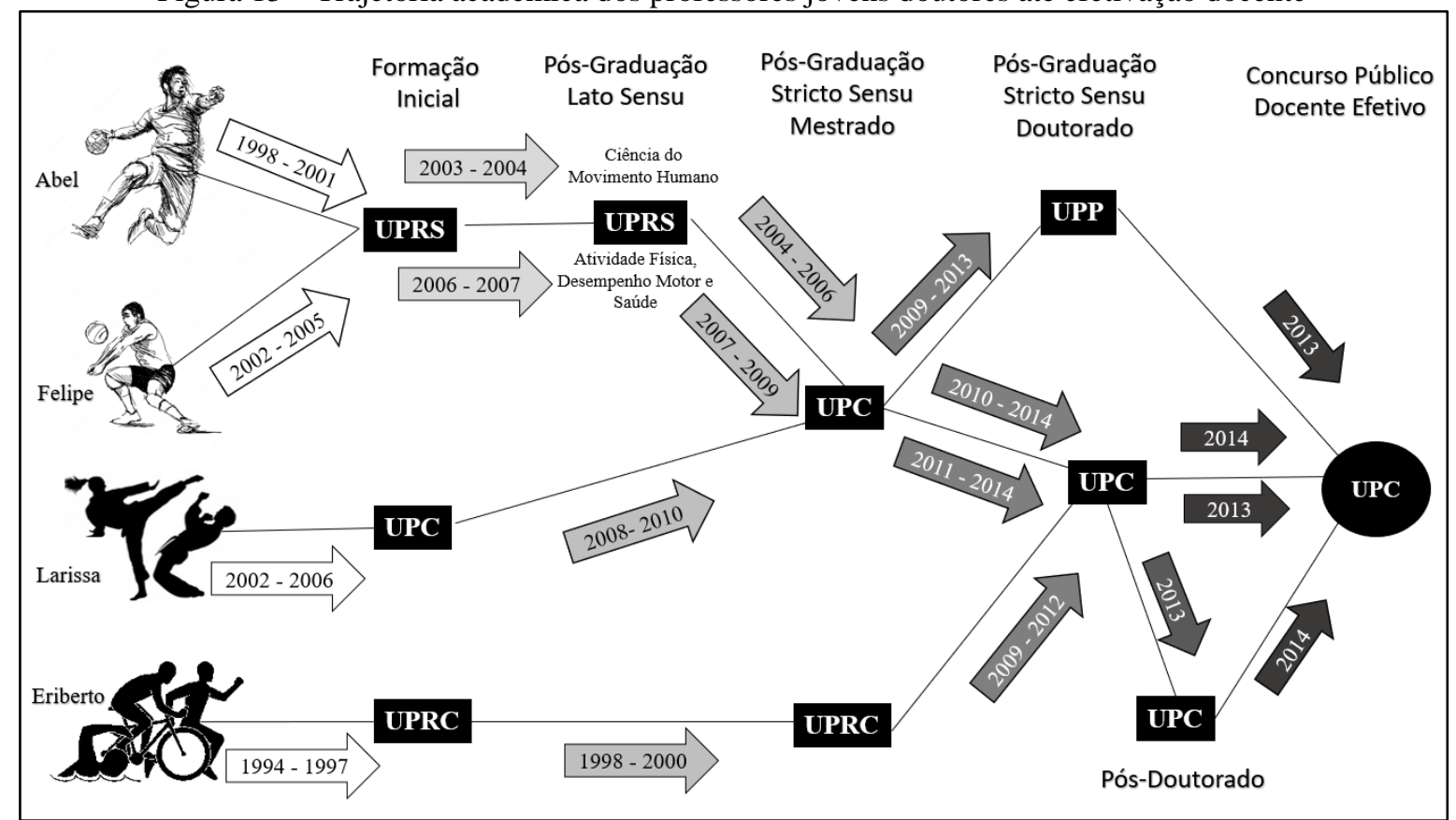

Fonte: Adaptações dos currículos lattes dos professores de Educação Física jovens doutores (2019)

Ao ingressar como docente, Felipe assumiu as disciplinas relacionadas ao esporte, mesmo assim precisou estudar muito, mas ao analisarmos o currículo lattes consta apenas as disciplinas atuais (2019). Abel começou atuar nos componentes de crescimento e desenvolvimento humano e no estágio em atividade física e saúde, conforme a entrevista, mas de acordo com seu lattes podemos acrescentar a disciplina de métodos de pesquisa em Educação Física.

E fui aprovado no concurso, então comecei dar aula, como era um concurso específico de esporte eu só dava aula de esporte. [...] dava aula de futebol e de voleibol para os cursos de Educação Física Licenciatura e Bacharelado. Também dei aula para EFC - Educação Física Curricular - e Fundamentos DidáticosPedagógicos do Esporte [...] A disciplina de fundamentos didáticos-pedagógicos foi bastante importante, porque no primeiro semestre eu tive que estudar bastante para conseguir discutir um pouco mais com isso com os alunos, as metodologias, as possibilidades e métodos de ensino [...] (FELIPE).

Enquanto Eriberto e Larissa não fizeram menção sobre as disciplinas que iniciaram ao ingressar como docentes efetivos. No currículo lattes e nas entrevistas identificamos as disciplinas que os jovens doutores lecionaram e/ou lecionam na graduação e no programa de pós-graduação da UPC (Quadro 12). 
Quadro 12 - Disciplinas lecionadas como professor efetivo da UPC

\begin{tabular}{|c|c|c|c|}
\hline Professor & Ano & Nível do Curso & Disciplina \\
\hline \multirow{3}{*}{ Larissa } & \multirow{2}{*}{ 08/2014- atual } & \multirow{2}{*}{ Graduação } & Metodologia do Judô \\
\hline & & & Biomecânica \\
\hline & N.I & $\begin{array}{l}\text { Pós-Graduação } \\
\text { M/D }\end{array}$ & $\begin{array}{c}\text { Bases Biodinâmicas do Movimento } \\
\text { Humano }\end{array}$ \\
\hline \multirow{3}{*}{ Felipe } & \multirow[b]{2}{*}{ 08/2014-atual } & \multirow[b]{2}{*}{ Graduação } & Teoria e Metodologia do Voleibol \\
\hline & & & $\begin{array}{l}\text { Estágio Supervisionado em Avaliação e } \\
\text { Prescrição de Exercícios }\end{array}$ \\
\hline & 03/2015-atual & $\begin{array}{l}\text { Pós-Graduação } \\
\text { M/D }\end{array}$ & $\begin{array}{c}\text { Bases Biodinâmicas do Movimento } \\
\text { Humano }\end{array}$ \\
\hline \multirow{4}{*}{ Eriberto } & \multirow{4}{*}{ N.I } & \multirow[t]{2}{*}{ Graduação } & $\begin{array}{c}\text { Teoria E Metodologia Do Treinamento } \\
\text { Esportivo }\end{array}$ \\
\hline & & & Adaptações Orgânicas Ao Exercício A \\
\hline & & $\begin{array}{l}\text { Pós-Graduação } \\
\text { M/D }\end{array}$ & $\begin{array}{c}\text { Bases Fisiológicas do Desempenho } \\
\text { Humano }\end{array}$ \\
\hline & & $\begin{array}{l}\text { Pós-Graduação } \\
\text { D }\end{array}$ & $\begin{array}{l}\text { Métodos Avançados de Pesquisa em } \\
\text { Biodinâmica do Desempenho Humano }\end{array}$ \\
\hline \multirow{5}{*}{ Abel } & \multirow[t]{2}{*}{ 09/2003-atual } & \multirow{3}{*}{ Graduação } & $\begin{array}{l}\text { Crescimento e desenvolvimento } \\
\text { humano }\end{array}$ \\
\hline & & & Estágio em atividade física e saúde \\
\hline & $\begin{array}{r}09 / 2003- \\
01 / 2004 \\
\end{array}$ & & $\begin{array}{c}\text { Métodos de pesquisa em Educação } \\
\text { Física }\end{array}$ \\
\hline & 01/2014-atual & $\begin{array}{l}\text { Aperfeiçoament } \\
\text { o Residência } \\
\text { multiprofissional } \\
\text { em Saúde da } \\
\text { Família }\end{array}$ & $\begin{array}{c}\text { Orientação atividades Serviço em } \\
\text { Saúde }\end{array}$ \\
\hline & 01/2015-atual & $\begin{array}{l}\text { Pós-Graduação } \\
\text { M/D }\end{array}$ & $\begin{array}{l}\text { Produção e veiculação do } \\
\text { conhecimento em Educação Física }\end{array}$ \\
\hline
\end{tabular}

Fonte: Adaptações dos currículos lattes e entrevistas dos professores de Educação Física jovens doutores (2019) N.I - Data não identificada;

M/D - Mestrado/doutorado; D - Doutorado.

A partir das informações expostas no Quadro 6, verifica-se que os docentes lecionam em disciplinas de sua área de formação do mestrado e doutorado. Eriberto, Larissa e Felipe na área esportiva relacionada à fisiologia e biomecânica do exercício. E Abel na área de atividade física e saúde, continuando afastado do esporte que inicialmente foi seu fator de impulsão à Educação Física.

O currículo lattes não categoriza se as disciplinas são do curso de Licenciatura ou Bacharelado em Educação Física, mas ao longo da entrevista apenas a professora Larissa aborda que a disciplina de teoria e metodologia do judô se alterna nos semestres entre esses cursos. Quanto aos demais, percebemos que as disciplinas estão relacionadas apenas ao curso 
de Bacharelado.

A atuação na pós-graduação em mestrado e doutorado faz parte da vivência docente de todos os professores. As disciplinas também estão associadas às experiências e área de pesquisa em que os professores atuam, além disso identificamos que houve compatibilidade nas disciplinas realizadas durante os estágios de docência por Larissa e Eriberto. Ao longo do mestrado e doutorado Larissa e Felipe faziam parte do mesmo grupo de pesquisa e estavam sempre desenvolvendo trabalhos juntos, e ao ingressarem como docentes permanecem nessa união, pois na pós-graduação compartilham a disciplina de Bases Biodinâmicas do Movimento Humano.

O professor atua na pós-graduação em uma disciplina que realizou enquanto mestrando. Além disso, permaneceu na área de residência multiprofissional, a qual iniciou na instituição em que lecionava no estado do Paraná, e auxilia nas atividades de serviço em saúde. Atualmente, também possui o cargo de gestor (coordenador) desse aperfeiçoamento, bem como transita em funções administrativas relacionadas à área de Educação Física dentro da IES. Além disso, também se envolveu como investigador ou coordenador de projetos de pesquisa (PP) e extensão (PE), atualmente está vinculado a quatro PP e um de PE.

Como sabemos, a docência universitária ultrapassa a barreira do ensino, o professor precisa estar munido de habilidades e competências para pesquisa e extensão. Com o tempo as demandas foram ultrapassando essas dimensões, integrando funções administrativas mais associadas à gestão (ZABALZA, 2004). Tal perspectiva foi evidenciada com os jovens doutores, embora a inserção na instituição seja recente, aproximadamente cinco e seis anos, estão assumindo todas essas funções.

Identificamos que a professora Larissa atua como coordenadora de extensão dos cursos de Educação Física e está vinculada a um projeto de PP. O docente Eriberto coordena um PE na sala de musculação e está filiado a três PE, sendo coordenador de dois destes.

O docente Felipe, atualmente (2019), é subcoordenador do programa de pósgraduação em Educação Física da UPC, quanto aos projetos, está associado a um de PP e um de PE. Na entrevista relata brevemente sobre sua atual situação quanto a orientações e expectativas futuras na docência e na pesquisa.

Atualmente, eu estou com três alunos de mestrado, um aluno de PIBIC e dois alunos de TCC, totalizando seis alunos. Não oriento no doutorado, vou me credenciar mais para frente. Meus alunos de mestrado, um está no segundo ano e os outros dois no primeiro ano, os projetos deles estão ligados a estas temáticas que te falei. [...] não tenho num projeto maior, encerramos um projeto maior algum tempo atrás que era um projeto guarda-chuva que os alunos estavam 
alocados mais ou menos. Atualmente não temos nenhum projeto maior, mas a nossa intenção é tentar elaborar um projeto maior para que conseguirmos realizar subprojetos, dentro desse maior, a fim de facilitar e direcionar um ou outro e assim por diante (FELIPE)

A orientação de estudantes na iniciação científica e na pós-graduação também se faz presente entre os docentes jovens doutores. Tal função não foi iniciada nessa instituição, mas enquanto estavam lecionando em outra IES e até mesmo quando eram estudantes de pósgraduação, puderem vivenciar essa atribuição que está associada à docência do ensino superior (Gráfico 8).

Gráfico 8- Orientações acadêmicas realizadas pelos jovens docentes

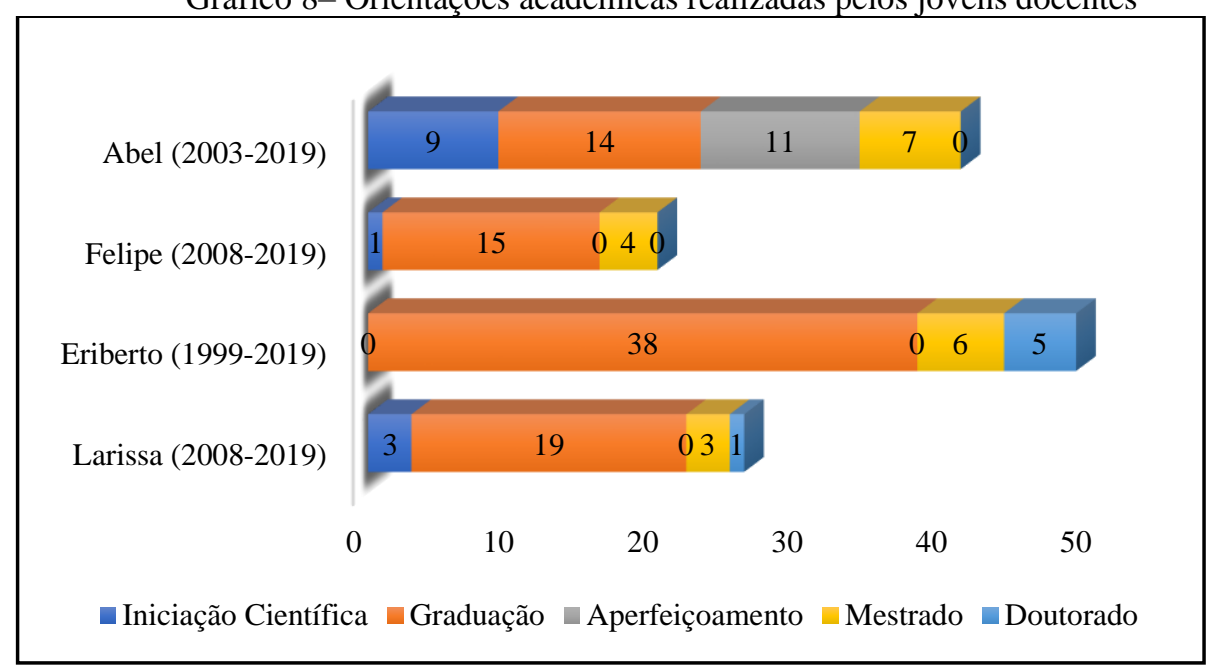

Fonte: Adaptações dos currículos lattes e entrevistas dos professores de Educação Física jovens doutores (2019)

As participações em bancas de avaliações desses tipos de trabalhos que orientam também fizeram parte de suas experiências no espaço universitário da instituição em que lecionam assim como em outras. Podemos destacar a professora Larissa, que participou como banca de avaliação em um processo seletivo e concurso público para professor de Ensino Superior em duas universidades públicas, uma em Santa Catarina e outra na Paraíba.

Com o envolvimento e experiência na pesquisa, normalmente, os professores atuantes no Ensino Superior são convidados para compor equipes de avaliação em periódicos de sua área correspondente, levando-os até a função de editores. Tal experiência também identificamos nos currículos lattes dos quatro professores, iniciada antes da inserção da UPC, exceto de Larissa, que corresponde a 2013, mas não especifica o ano, dificultando nossa interpretação. Entretanto todos apresentavam o mestrado concluído e experiência na área da docência no Ensino Superior. Atualmente (2019) todos os jovens doutores atuam em periódicos nacionais e internacionais, em virtude disso firmamos a ideia de que apresentam 
reconhecimento científico no Brasil e em outros países.

Devido à curiosidade pelo número de produções científicas que foram realizadas no período da graduação até hoje (2019), construímos individualmente uma tabela (disponível no cap. 4) que contempla a categoria da publicação e o período em que foram divulgadas na descrição de cada professor. A título de comparação, contudo, construímos um gráfico para que possamos analisar em qual categoria de trabalho científico os docentes se debruçaram intelectualmente (Gráfico 9).

Gráfico 9 - Produção do conhecimento dos professores jovens ao longo da trajetória acadêmica e profissional

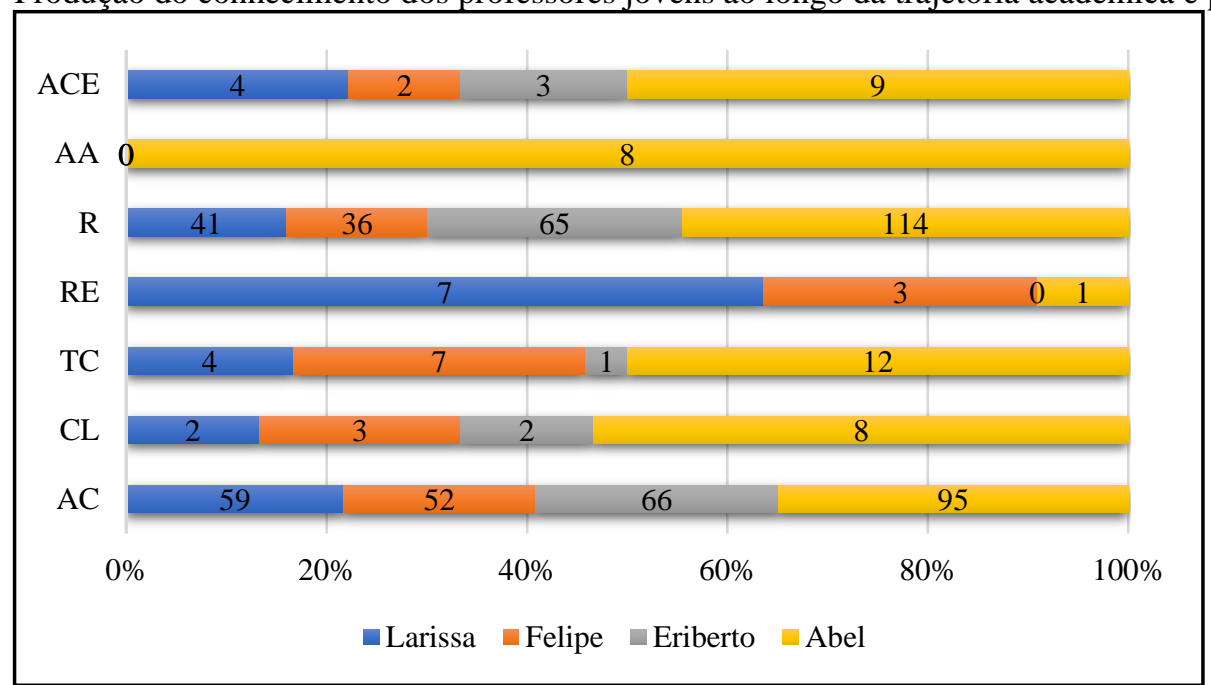

Fonte: Adaptações dos currículos lattes dos professores de Educação Física jovens doutores (2019)

ACE - Artigos aceitos;

AA - Artigos em anais de eventos;

$\mathrm{R}$ - Resumo - publicações em anais de eventos;

RE - Resumo expandido - publicações em anais de eventos;

TC - Trabalho completo - publicações em anais de eventos;

CL - Capítulo de livro;

AC - Artigos completos publicados em periódicos.

Identificamos que as produções dos jovens doutores estiveram centradas em artigos completos publicados em periódicos ( $\mathrm{AC} \mathrm{n}=272$; $\mathrm{ACE} \mathrm{n}=18$ ) e resumos publicados em anais de eventos ( $\mathrm{R} n=256)$. Dentre os professores, Abel apresentou mais produções em detrimento dos demais professores, exceto em resumo expandido publicado em anais de evento, que Larissa apresentou mais trabalhos $(\mathrm{RE} n=07)$.

No Gráfico 9 separamos os artigos publicados e os artigos aceitos (que estão em processo de publicação) então constatamos que todos os docentes estão com trabalhos nesse processo. Ao analisarmos as tabelas sobre as publicações mencionadas no capítulo 4 entre 2016 até 2019, identificamos de forma crescente o número de artigos publicados e/ou aceitos dos jovens doutores: Felipe com 18 ( $\mathrm{AC} n=16$; $\mathrm{ACE} n=02)$; Eriberto $\operatorname{com} 21$ (AC n=18; ACE $\mathrm{n}=03$ ); Larissa com 24 (AC $\mathrm{n}=21$; ACE $n=04)$; e Abel com 40 (AC $n=21$; ACE $n=09)$. 
Quanto à formação complementar e participações em eventos, não apresentam a mesma frequência no currículo lattes como essas publicações, pois Abel foi o único docente a mencionar que em 2018 realizou essas duas formações. Larissa também cita que participou em um evento em 2018, enquanto a outra formação, a última, ocorreu em 2010. Felipe - 2013 e 2016 - e Eriberto - 2010 e 2015 - não citam participações recentes, mas isso não significa que não realizaram. Compreendemos, entretanto, que há uma importância diferenciada entre a menção no currículo lattes sobre as publicações e demais formações.

Durante a trajetória profissional Abel, Larissa e Eriberto receberam algum tipo de prêmio ou homenagem: o primeiro professor, em 2010 foi paraninfo da turma para a qual lecionava; a segunda professora recebeu prêmio de melhor tese na UPC (2015) e menções honrosas em dois eventos científicos nacionais (2016; 2017); e o terceiro docente recebeu o prêmio de melhor orientador nos cursos de Educação Física quando atuava em Franca (2000; 2002; 2003; 2004) e duas menções honrosas em eventos científicos $(2006 ; 2008)$.

Ao analisarmos a história de vida e a entrevista estruturada com a Professora Larissa, percebemos que as experiências acadêmicas foram marcantes em sua trajetória pessoal e profissional, pois tal fato é notório em seu discurso. As vivências que antecederam à inserção na graduação pouco aparecem, consideramos que sua timidez, aborda isso em uma das entrevistas, pode ter influenciado nesse olhar ao falar sobre sua história de vida.

O professor Felipe apresentou experiências esportivas significativas ao longo da sua trajetória pessoal e profissional a partir das práticas propriamente ditas, participações em projetos de pesquisa e extensão. Observamos que enfatizou ao longo da sua história de vida mais essas vivências com o esporte, a formação de graduação e pós-graduação stricto sensu, ofuscando detalhes da trajetória familiar e da pós-graduação lato sensu. Também identificamos que suas experiências profissionais estiveram centradas no universo universitário, não constando experiência em outros espaços de atuação desse profissional de Educação Física.

Percebemos que o Professor Eriberto traz para sua vida pessoal e profissional as vivências que o esporte lhe proporcionou e o quanto estreitaram a sua relação com os irmãos. Também verificamos a presença significativa do referencial de seus pais, principalmente de sua mãe, na escolha profissional, por isso entendemos que esses foram os pontos marcantes ao longo de sua trajetória. Hoje, as disciplinas que leciona e as pesquisas que desenvolve estão relacionadas às experiências esportivas na condição de atleta e da formação que buscou ao longo de sua trajetória profissional. Suas experiências enquanto profissional externo ao ambiente acadêmico ocorreram em dois momentos, mas ambas foram desenvolvidas 
concomitantemente com a docência universitária, a qual predominou em sua trajetória profissional.

O professor Abel nos mostrou que o esporte marcou sua vida pessoal e profissional, ao mesmo tempo que o aproximou da Educação Física e o levou a explorar outros caminhos nessa área. Percebemos que houve uma mudança de perspectiva ao ingressar no mestrado e mudar de cidade, levando-o ao amadurecimento tanto pessoal quanto profissional. Traz consigo as vivências marcantes de quando era estudante da Educação Básica no interior do estado do Rio Grande do Sul para a atuação docente hoje. Ao longo da entrevista menciona que a condição de se tornar pai fê-lo olhar o trabalho de outra forma, administrar melhor seu tempo e suas demandas de trabalho. Também identificamos que Abel preocupa-se com sua formação continuada, está em constante busca pelo conhecimento. Sua experiência profissional, no início da carreira, esteve centrada no esporte, enquanto árbitro e preparador físico, depois voltou-se para as questões acadêmicas.

\subsection{A CONSTRUÇÃO DAS IDENTIDADES DOS PROFESSORES JOVENS DOUTORES}

A partir desse cenário encontrado conseguimos identificar a trajetória pessoal e profissional dos professores jovens doutores, a qual também contribui para verificarmos a construção identitária. Em virtude disso, fundamentadas em Goffman (1988), Dubar (2005) e Alves et al. (2007) alinharemos a construção da identidade docente dos professores de Educação Física jovens doutores que atuam em uma universidade pública de Santa Catarina. Para que possamos realizar essa análise, identificamos, a partir trajetória pessoal e profissional, os espaços da socialização primária e secundária dos professores, as quais se originam desde seu nascimento até a constituição familiar e o espaço de atuação profissional UPC (Figura 14).

Reconhecemos que cada indivíduo é único, apesar da existência de algumas vivências serem identificadas de forma semelhante, aproximando uns dos outros, mas os impactos das socializações reagem de formas diferentes entre os docentes. Também consideramos que a identidade docente não se constitui sozinha, mas a partir do processo relacional e biográfico. 
Figura 14 - Socialização primária e secundária dos professores de Educação Física jovens doutores

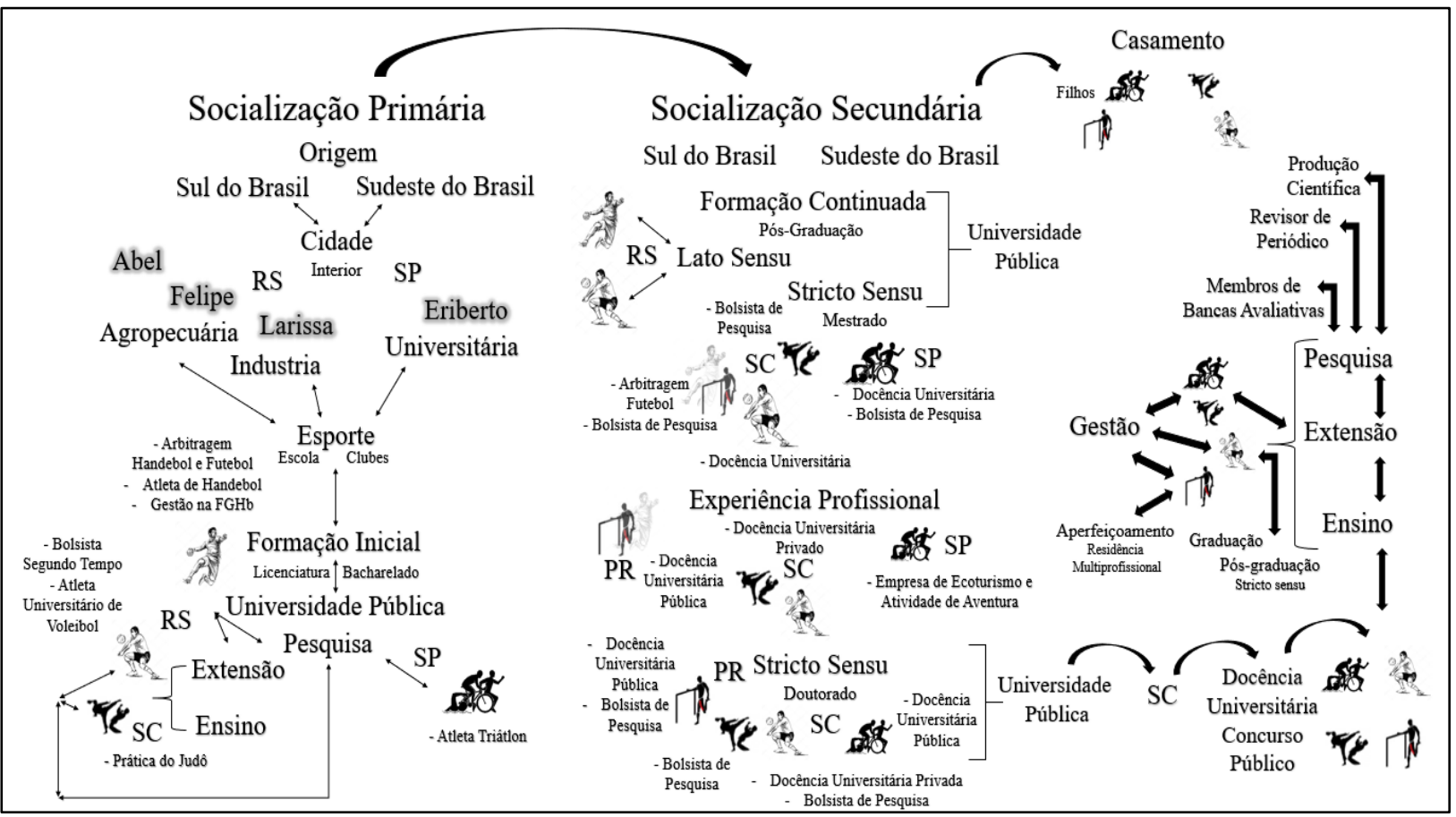

Fonte: Adaptações dos currículos lattes e das entrevistas dos professores de Educação Física jovens doutores (2019)

Para discutirmos a configuração identitária dos professores, primeiramente precisamos olhar para seus primeiros espaços de socialização. Na construção da identidade docente do professor Eriberto compreendemos que foi importante a presença de pais professores de Ensino Superior, a vivência no espaço universitário e a relação social com pessoas que o frequentam. O próprio professor reconhece que os seus irmãos vivenciaram as mesmas experiências que ele, mas esse olhar para a universidade despertou apenas nele. " $E u$ tenho dois irmãos que são gêmeos, entre eles, não é nenhum dos dois seguiu carreira acadêmica, para ver que todo mundo estava sobre a mesma influência, mas para mim despertou de uma forma diferente essa vontade de seguir carreira acadêmica" (ERIBERTO).

Ao contrário dos professores Abel e Felipe, cujo contexto familiar estava relacionado aos conhecimentos e vivências agropecuárias, os quais marcaram suas primeiras experiências infantis. Quanto a Larissa não menciona sua infância, mas percebemos que seus pais não apresentavam conhecimento acadêmico, assim percebemos que a experiência mais próxima sobre a docência era de sua tia, que atuava como professora.

Outros dois espaços que marcaram a socialização primária dos professores jovens doutores foram a escola e clubes (locais em que praticavam atividade esportiva). Esses dois espaços os aproximaram do esporte, da Educação Física e da docência, consequentemente, possibilitaram experiências que contribuíram para a construção de sua identidade social. 
Fundamentamos tal concepção a partir da perspectiva de Dubar (2005, p. 147):

Contudo, é nas e pelas categorias dos outros - e principalmente dos parceiros de
escola (seus "professores" e seus "colegas") - que a criança vive a experiência de
sua primeira identidade social. Esta não é escolhida, mas conferida pelas
instituições e pelos próximos com base, não somente nos pertencimentos étnicos,
políticos, religiosos, profissionais e culturais de seus pais, mas também em seu
desempenho escolar [...] Dessa dualidade entre identidade para o outro conferida e
identidade para si construída, mas também entre identidade social herdada e
identidade social visada, se origina um campo do possível no qual se desenvolver
já a infância, na adolescência, e no decorrer da vida, todo as estratégias identitárias.

Além disso, nos relatos dos professores identificamos a contribuição de professores, treinadores e da prática esportiva em si para a escolha profissional, que os levaram à formação inicial em Educação Física. Verificamos que no processo biográfico a transação subjetiva à identidade herdada pelo espaço profissional dos pais ocorreu de forma contínua para Eriberto, enquanto a formação inicial de seus pais, que eram médicos veterinários, passou por uma ruptura, deixando de escolher biologia (área profissional mais próxima de seus pais) e apresentando uma identidade visada no contexto esportivo. A vivência com o esporte, em diferentes espaços de socialização em sua infância e adolescência, possibilitou a incorporação e o sentimento de pertencimento àquela área de atuação, mas identificamos ao longo do discurso de Eriberto que a identidade constituída no espaço universitário ainda o marcava, tornando-se visada. Assim, no longo prazo, a transação objetiva passou a uma identidade incorporada quando se tornou professor universitário, como seus pais.

O processo biográfico, no primeiro momento, foi semelhante entre Abel, Felipe e Larissa quanto à identidade herdada atrelada ao espaço de atuação profissional de seus pais, pois identificamos a primeira ruptura em suas identidades, a herdada e a visada, sendo essa segunda atribuída a partir dos espaços escolar e clubes em que praticavam esporte. A socialização primária nesses contextos permitiu que os docentes começassem a se sentir pertencentes a um grupo de trabalho diferente daqueles que seus pais os aproximaram agricultura e indústria. Além disso, constatamos nas entrevistas que seus pais não apresentavam conhecimento da área da Educação Física e a escolaridade era até a Educação Básica, assim identificando que visavam à formação com diploma associada ao esporte, grupo de reconhecimento e pertencimento.

A partir dessa contextualização sobre a socialização primária verificamos que se encaminhou a escolha profissional dos professores quanto a profissionais de Educação Física. Ao ingressarem na graduação, iniciaram a construção da identidade profissional, a qual foi alicerçada pelas práticas esportivas, principalmente os professores Eriberto (triatlo), Abel 
(handebol) e Felipe (voleibol). A professora Larissa não apresentava um esporte que a representasse, mas foi na graduação que se aproximou do judô, tornando-se parte fundamental na sua identidade profissional.

A formação inicial dos professores foi marcada pelo contexto de universidade pública, na qual predominava o ensino, pesquisa e extensão. Identificamos nesses três espaços que a pesquisa apresentou papel significativo em suas trajetórias profissionais como um todo, passando os docentes a incorporarem uma identidade de pesquisadores na área da Educação Física. Isso se torna evidente a partir do envolvimento quantitativo em projetos de pesquisa e publicações encontrados em seus currículos lattes, em detrimento das experiências profissionais que não contemplam o espaço acadêmico. As experiências enquanto profissionais fora do espaço universitário foram restritas a Abel e Eriberto, mas logo esses professores se afastaram para centralizarem profissionalmente nas atribuições da docência do Ensino Superior.

É importante salientar que não estamos minimizando a contribuição das outras vivências dos professores ao longo de sua trajetória profissional para a construção de sua identidade, entretanto as marcas encontradas, relacionadas à pesquisa e ao esporte, foram significativas para os docentes universitários que encontramos nas entrevistas. Para complementar tal afirmação, também identificamos que a docência na Educação Básica pouco se fez reconhecida entre os professores investigados, apesar de Abel, Felipe e Larissa apresentarem uma formação que propiciou tal conhecimento.

A identidade para si de Eriberto, na condição de professor universitário, estava visada antes de ingressar na graduação em Educação Física, mas para Abel foi nessa época que ocorreu a transição subjetiva dessa identidade. A partir das vivências ocorridas na graduação, a instituição que estudava apresentava uma relação estreita entre a formação inicial e a pósgraduação, proporcionado aos alunos experiências na pesquisa e com professor com vivências internacionais, conduziram o jovem doutor à docência universitária.

Algumas coisas me marcaram muito na minha formação que me levaram a ser professor universitário hoje. Primeiro a estar naquele momento na universidade, naquele estágio, poder conviver com os mestrandos e doutorandos, coisas que se não tivesse o programa eu não teria vivenciaria isto e não tivesse me influenciado. Segundo foi conhecer alguns professores que fizeram o mestrado e doutorado fora do país. Eles traziam uma experiência de quanto era interessante essa formação de nível continuado de mestrado e doutorado, e as possibilidades que existiam. Então eu tive um professor de medidas e avaliação que influenciou bastante. Foi o primeiro profissional que me abriu as portas para fazer iniciação científica $(A B E L)$. 
O esporte continuou inserido no contexto profissional dos docentes, mas relacionado ao âmbito investigativo, exceto para Abel, cujas vivências no ambiente esportivo enquanto profissional fez com que não se reconhecesse mais nesse grupo. Dessa forma procurou o mestrado na área de atividade física e saúde e, aos poucos, foi se distanciando do esporte, caminhando para outra especificidade dentro da Educação Física.

Embora todos os professores tenham realizado suas formações em universidade pública, em algum momento da trajetória acadêmica mudaram de cidade, estado e de instituição. Em especial Eriberto, Abel e Felipe, que realizaram a graduação em locais diferentes da pós-graduação. Tal transição lhes permitiu a socialização com diferentes pessoas, hábitos regionais e uma nova política institucional, assim possibilitando uma (re)construção na identidade profissional.

Com a professora Larissa consideramos que os momentos em que mudou de cidade, com dezesseis anos e depois morar sozinha, foram considerados importantes na construção de sua identidade pessoal e social. Em consequência, consideramos que essa permanência na UPC da graduação até hoje, enquanto docente, está relacionada a uma identidade profissional reconhecida e pertencente, isto é, assumida junto a essa instituição. Ao longo da sua trajetória profissional, aproximadamente um ano e meio atuou em outra instituição de ensino, mas havia ainda o vínculo com o grupo de pesquisa e projetos desenvolvidos na UPC. A identidade profissional da professora foi constituída juntamente com as relações, hábitos, política institucional, comunidade acadêmica dentre outros aspectos que incorporam a UPC, logo, assumiu para si tal identidade.

O professor Abel relata sobre o seu desenvolvimento enquanto pessoa, profissional e pesquisador. Também reconhece a importância do envolvimento com outras pessoas que apresentavam conhecimento científico no âmbito nacional e internacional como professores nas instituições e grupos de pesquisa que participou no Brasil e em Portugal. Diferentemente de Larissa, a construção da identidade docente de Abel ocorreu em diferentes espaços de socialização, mas ao longo de suas falas declarava o reconhecimento pela UPC como uma instituição de qualidade. Em virtude disso, compreendemos que retornar à instituição como docente foi além das questões familiares, o professor sentia-se pertencente àquela instituição com a qual compartilhava as mesmas concepções.

Quanto a Eriberto, mudou de cidade, estado e instituição, mas o professor orientador permaneceu até o pós-doutorado. A partir desse aspecto entendemos que houve uma transição objetiva assumida que o leva ao reconhecimento pelo orientador. Isso possibilitou que o docente continuasse buscando o que visava. O sentimento de pertencimento ao que estava 
vivenciando na UPC o fez realizar o concurso para essa instituição, ao contrário do que estava vivenciando em São Paulo, pois enfatiza na entrevista que nada o prendia naquela vida, por isso se mudou para cursar o doutorado.

A mudança de Felipe para Santa Catarina existiu, mas não foi mencionado de forma marcante ao longo da pesquisa. Entretanto a permanência do professor na instituição (UPC) nos leva ao entendimento de que também se sentiu reconhecido pela sua orientadora, pois realizou o mestrado e doutorado com ela, além da sensação de pertencimento. $\mathrm{O}$ envolvimento do professor em grupos de estudos, projetos de pesquisa e extensão e a relação com a comunidade universitária contribuíram para a permanência na instituição como docente.

A identidade social virtual do professor do Ensino Superior está relacionada a profissionais e/ou pesquisadores que ingressam na docência por distintos motivos, os quais apresentam conhecimento e experiência técnico-científica, mas pouco ou nada sobre conhecimentos pedagógicos e os atributos relacionados à docência (PIMENTA; ANASTASIOU, 2010; PEREIRA; MENDEIROS, 2011; ALMEIDA, 2012; THERRIEN; DIAS; LEITINHO, 2016) - “[...] esse ponto que mais carente de nossos professores universitários quando se fala em profissionalismo na docência” (MASETTO, 2015a, p. 32). Em virtude dessa percepção sobre esse docente, espera-se que os professores que atuam no Ensino Superior apresentem domínio dos conhecimentos básicos da sua área específica, experiências profissionais de campo, conhecimentos e práticas profissionais atualizadas, conhecimento de pesquisa relacionada a sua área de formação e domínio na área pedagógica (MASETTO, 2015a).

Nesses aspectos verificamos que os professores jovens doutores apresentaram uma experiência profissional restrita da área específica de formação, mas isso não significa que não apresentaram um domínio de conhecimento básico sobre a Educação Física. A formação acadêmica e complementar, bem como as participações em eventos, revelara-nos que apresentam conhecimento na área e de certo modo atualizadas, ainda que apenas Abel e Larissa tenham se envolvido em atualizações no último ano, segundo seus currículos lattes.

Ao olharmos a produção do conhecimento dos professores, ficou evidenciado o conhecimento e o envolvimento na área da pesquisa. No entanto essa grande demanda nos remete a duas reflexões: a primeira está associada a exigências dos programas de pósgraduação referente à publicação dos seus professores, consequentemente de seus orientandos. O Sistema Nacional de Pós-Graduação (SNPG) da Capes utiliza como um dos critérios para qualificá-los a quantidade de produções existentes. Em virtude disso, 
compreendemos que esse seja o motivo da predominância de publicações em periódicos nacionais e internacionais em relação a participações em eventos e formação complementar. Tal condição faz com que o docente se adapte às exigências do espaço formativo, consequentemente, para ser reconhecido enquanto profissional associado à pesquisa e docente do Ensino Superior.

Ao longo de nossas leituras identificamos a reflexão de Silva et al. (2017) sobre esse cenário de publicações do professores universitários que atuam nos programas de pósgraduação, a qual parte da seguinte percepção: os docentes para se credenciarem nos programas precisam atingir uma pontuação referente à produção científica, consequência disso, ao ingressarem conseguem realizar suas pesquisas, bem como aumentar sua produtividade, principalmente em periódicos de fator de impacto. Esse processo, segundo esses autores, é considerado capital simbólico, relacionado a hierarquias de poder no interior do campo, devido à posição de prestígio no âmbito universitário pelo vínculo com o programa de pós-graduação.

Há outros fatores que contribuem para esse cenário de prestígio e aceleração da produtividade, que Silva et al. (2017) consideram o capital social, quais sejam: o sistema de coautorias, a institucionalização de grupos de pesquisa e a efetivação de amplas redes de parceria nacionais e internacionais. Além disso, contribui para o capital científico e cultura do professor.

A partir desse reconhecimento dá-se nossa segunda reflexão, pois a necessidade de se sentir pertencente ao grupo em que está inserido pode levar os docentes a essa maior preocupação com a produção intelectual. Associado a isso há questionamentos sobre até que ponto o conhecimento está sendo produzido de uma forma válida para que possa contribuir de forma significativa para o desenvolvimento científico, social e para a área profissional. $\mathrm{O}$ interesse de produção acaba sendo questionado e criticado, por isso corroboramos que devemos repensar essa perspectiva de produção acelerada e exacerbada que ocorre na Educação Física.

[...] a produtividade e o fetiche do conhecimento-mercadoria se institui como uma moeda no "mercado" acadêmico: gera status ao pesquisador que o detém, produz benefícios como acesso a financiamentos, fortalecimento dos laboratórios, convite para consultorias remuneradas, poder nos departamentos e programas de pósgraduação, enfim, gera um capital acadêmico simbólico e material [...] (PIRES; POFFO, 2017, p. 05).

Essa questão de reconhecimento no espaço universitário pode ser identificada pelas 
produtividades e envolvimento que o docente apresenta nesse contexto, os quais resultam no recebimento de premiações e cargos de gestão, ambos encontrados entre nossos jovens doutores. Certamente, isso permite que o professor se sinta valorizado pelo trabalho desenvolvido e prestígio profissional perante seus pares, superiores e alunos.

Quanto ao conhecimento pedagógico dos jovens doutores, verificamos que esteve próximo de suas trajetórias formativas. Percebemos que Abel apresentou mais envolvimento com disciplinas de cunho pedagógico referentes à Educação Básica e ao Ensino Superior, mas também realizou estágio de docência no mestrado e doutorado. A formação inicial do professor Eriberto não apresentou disciplinas de cunho pedagógico, mas no mestrado e no doutorado realizou uma disciplina que abordava esse conhecimento especificamente ao Ensino Superior, bem como estágio de docência.

Para Felipe e Larissa as disciplinas desse caráter ocorreram mais na graduação, entretanto a monitoria, ao longo da graduação, os aproximou da docência universitária, além dos estágios realizados na pós-graduação e uma disciplina no doutorado. Nesse contexto Larissa reconhece a contribuição do estágio, mas a pós-graduação esteve mais focada à área da pesquisa.

\footnotetext{
acredito que a pós-graduação contribuiu de uma maneira mais específica para pesquisa. Eu sempre tive um gosto para pesquisa, na pós tive isso mais forte e as disciplinas estão voltada mais para a pesquisa [...] o próprio estágio de docência que faz nos expor perante os alunos e sermos avaliados por eles e pelos professores, mas na após a pesquisa predominou mais do que à docência. Ajudou, logicamente ajudou, mas não foi o principal (LARISSA).

Eu tenho as experiências das aulas da graduação que tinha uns professores que faziam de um jeito, que eu via que esse não dá certo, mas esse outro jeito é legal. Essas são as experiências da graduação, mas isso a gente acaba descobrindo só mais tarde [...] E talvez na formação da pós-graduação o mais determinante foi você conseguir fazer esse julgamento das melhores estratégias e metodologias mais adequadas para determinados momentos. Essa reflexão ocorreu na pósgraduação, nas disciplinas no doutorado [...] esse momento foi o mais importante para essa formação de pensar mais críticos para pensar suas metodologias e atuações docentes
}

Além disso, consideramos outros fatores que contribuíram para a formação docente dos jovens doutores, os quais foram: a vivência com professores que apresentavam domínio pedagógico e os auxiliaram nessa formação; também as experiências como professores do Ensino Superior antes de assumir a função na UPC. O primeiro ficou evidente no relato de Abel, Larissa e Felipe sobre a importância de alguns professores da graduação e da pósgraduação para um olhar pedagógico que os auxilia até hoje em suas práticas pedagógicas. O segundo aspecto proporcionou autonomia docente e autorreflexão sobre suas práticas. 
E quando eu vim para cá eu fui supervisionado pela professora, que não está mais aqui, mas fez a diferença no meu mestrado em termos didáticos e aprendizagem, que foi a Professora [Nome]. Ela me orientou no meu mestrado, porque o meu professor estava viajando, no pós-doutorado. Então, eu fiquei por um ano e meia sob a supervisão dela e foi muito interessante, principalmente nas questões pedagógicas, aprendi várias coisas como dar aula, de como tratar o alunos, eu aprendi muito com ela, coisas que era muito importante e interessante que ela fazia e que eu tento fazer como: retomar aula do ponto da aula anterior, fazer uma revisão, e fazer com que os alunos participantes dessa revisão, ver o que eles lembram daquilo. E parece que os alunos gostam de fazer isso e a motivação para eles de lembrar do que foi trabalhado. Isso aprendi com ela, além disso, a valorização do ensino básico para formação básica mesmo. E não a especialização na formação básica (ABEL).

Ao analisarmos a trajetória pessoal e profissional dos jovens doutores, podemos assegurar que a identidade real desses docentes está mais próxima do que se almeja para um professor universitário, tal qual menciona Masetto (2015a) sobre a identidade virtual que lhes é atribuída. Além disso, podemos constatar que a identidade desses docentes se constitui e reconstitui a partir dos dilemas mencionados por Zabalza (2004) quanto ao: individualismo/coordenação; investigação/docência; generalista/especialista; ensino/aprendizagem.

Quanto aos modelos identitários atribuídos por Dubar (2005) e Alves et al. (2007) identificamos que a configuração identitária que mais se enquadrou entre os docentes jovens doutores foi a identidade de responsável em promoção interna, atrelado do modelo "carreirista" ao processo de mobilização. Conforme a Figura 15 podemos verificar as três perspectivas expostas sobre a configuração identitária dos jovens doutores.

Figura 15 - Configuração identitária dos professores de Educação Física jovens doutores

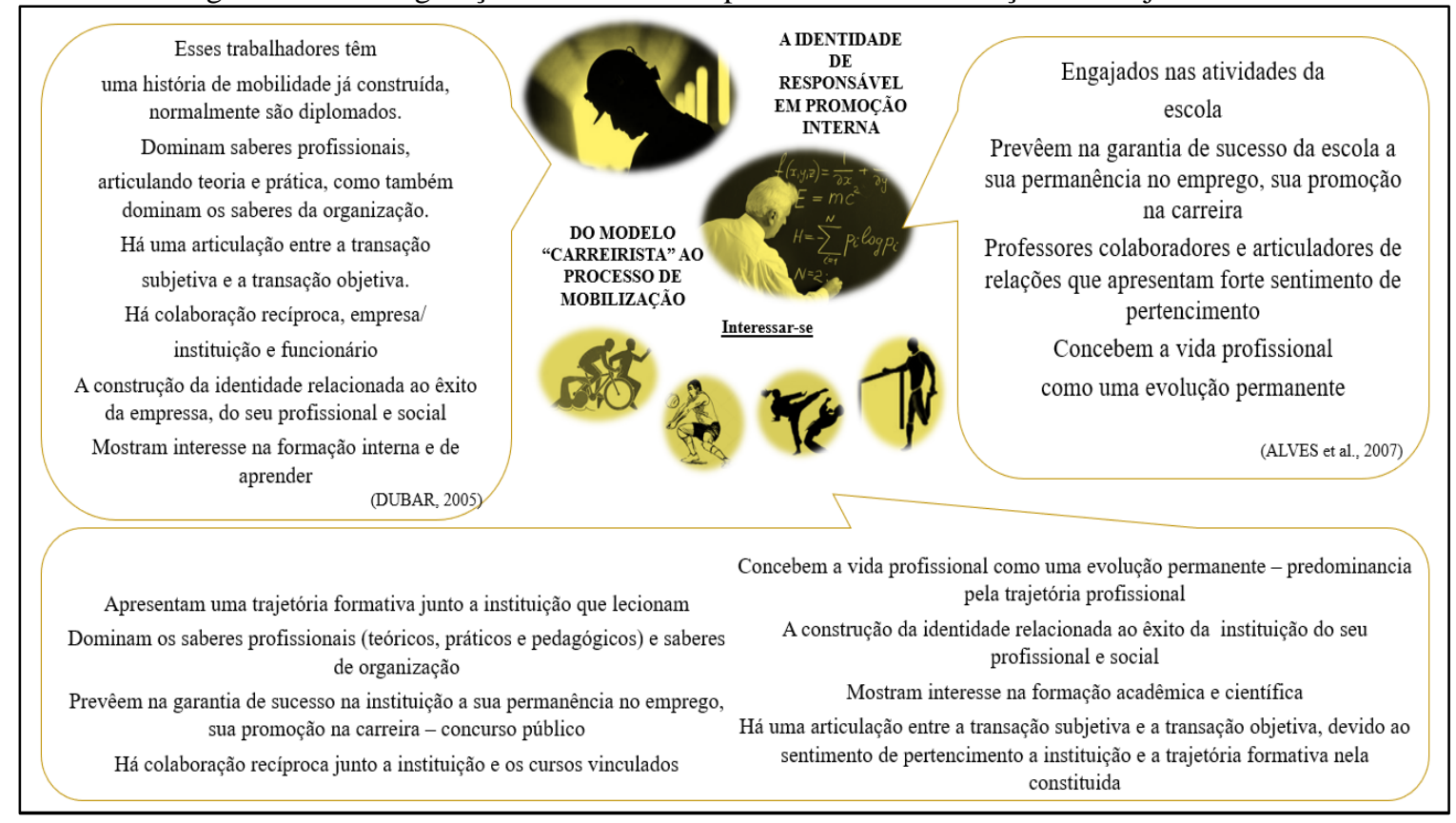

Fonte: Elaborada pela pesquisadora (2019) 
Essa configuração revela que os trabalhadores apresentaram uma história de mobilidade junto à empresa, nesse caso, os docentes também que iniciaram na condição de estudantes, graduação (Larissa), mestrado (Larissa, Felipe e Abel), doutorado (Larissa, Felipe e Eriberto) e pós-doutorado (Eriberto) até se tornarem docentes efetivos. Após assumirem a docência também assumem papéis de gestores dentro do centro vinculado, ainda Abel transita para outro relacionado à residência multiprofissional. Nesse cenário de envolvimento compreendemos que há uma relação recíproca com a instituição e comunidade universitária, caso contrário não estariam integrados a comissões, gestões e projetos, além da docência em si. Além disso, revela-nos que se importam com o desenvolvimento da instituição, articulando com seu próprio êxito, buscam contribuir para a melhoria da qualidade de ensino, pesquisa e extensão da universidade, consequentemente, são reconhecidos pela instituição e como profissionais.

Esse cenário de envolvimento em diferentes espaços dentro da universidade, em um período de cinco e seis anos como professores efetivos, revela-nos que os jovens doutores podem apresentar características profissionais polivalentes, descritas no modelo do operário ao "novo profissional". Como apresentaram essa característica de recém-doutores, apresentam um conhecimento atualizado, às vezes, inovador para a instituição, dessa forma podemos entender essa aproximação com tanto envolvimento em diferentes espaços na instituição. Essa é a única configuração com que reconhecemos o outro modelo, pois está associado ao novo profissional.

Os saberes profissionais e de organização também são relacionados à função exercida, ao compararmos um professor universitário e outro profissional que atuam em uma empresa, no que diz respeito à especificidade da função. Como são professores concursados, possuem cargo efetivo, relacionado a um plano de carreira.

No discurso sobre história de vida dos professores enfatizam mais a trajetória profissional em detrimento das questões pessoais, é o caso de Abel e Eriberto que apresentaram apontamentos mais pessoais. Também identificamos que há preocupação com a formação profissional, mas centrado às questões acadêmico-científicas, pois a formação complementar, participação em eventos científicos, envolvimento em grupos e projeto de pesquisa e a demanda de publicações científicas nos revelam essa preocupação ocorrendo dentro ou fora da instituição. Em nenhum momento foi relatado pelos jovens doutores que buscaram uma formação que não estivesse relacionada à área profissional. 
Ao longo da trajetória acadêmica dos professores identificamos que todos apresentaram uma sensação de pertencimento e reconhecimento frente à instituição em que lecionam (UPC), e isso fazendo com ingressassem como docentes. Para a construção da identidade profissional dos jovens doutores houve contribuição da comunidade universitária e das políticas das instituições da UPC antes de se tornarem professores efetivos da instituição, o que contribuiu para tais sensações e retorno.

A construção das identidades dos professores jovens doutores foi marcada por diferentes espaços de socialização ao longo das trajetórias pessoal e profissional, cuja contribuição significativa nesse processo foi dada pelo esporte. Também afirmamos que a UPC favoreceu e representa parte da identidade profissional desses docentes, fazendo com que se sentissem pertencentes e reconhecidos pela IES. Apesar de serem jovens doutores, nos revelaram que a identidade social virtual dos professores universitários não condiz com sua identidade real, embora a experiência no campo da Educação Física seja reduzida, os docentes buscam se atualizar e estarem próximos do desenvolvimento da profissão.

A partir desse cenário podemos afirmar que os jovens doutores apresentam uma identidade responsável em promoção interna, associada à identidade da instituição. A “transação objetiva a transação subjetiva se fortalecem e se confirmam mutuamente na construção de uma identidade tanto reconhecida na empresa quanto socialmente legitimável" (DUBAR, 2005, p. 293). 


\section{CAPÍTULO 6 \\ A CONSTRUÇÃo dA PRÁTICA PEDAGÓGICA DOS PROFESSORES DE EDUCAÇÃO FÍSICA JOVENS DOUTORES}

No presente capítulo discutimos sobre a construção da prática pedagógica dos professores de Educação Física jovens doutores a partir da forma como se organizaram, se desenvolveram e as contribuições da trajetória pessoal e profissional dos docentes. Utilizamos como subsídio as informações coletadas nas entrevistas (história de vida e estruturada), observações de aulas e plano de ensino das disciplinas que os professores lecionam.

\subsection{ORGANIZAÇÃO E DESENVOLVIMENTO DAS PRÁTICAS PEDAGÓGICAS}

Para discutirmos sobre as práticas pedagógicas dos professores jovens doutores, decidimos iniciar pela análise do plano de ensino da disciplina que lecionam no qual também observamos aulas, pois iniciam a organização de suas disciplinas, como pretendem desenvolvê-la e o que almejam alcançar. Desta forma, pudemos entender que esse documento sistematiza as ações educativas desenvolvidas pelo professor e seus estudantes, cujos objetivos o norteiam. Além disso é flexível, possibilitando a integração de novas demandas que vão surgindo ao longo da formação (GIL, 2009b; MASETTO, 2015a)

O planejamento da disciplina por muito tempo foi identificado como um procedimento burocrático, exigido pela secretaria acadêmica. Os docentes o reaplicavam e as alterações realizadas condiziam apenas com as datas referentes ao semestre letivo. Essa perspectiva vem se modificando, mas ainda presente entre alguns professores (MASETTO, 2015a; 2015b). Tal mudança está atribuída a um planejamento que contribui na formação profissional dos estudantes a partir do desenvolvimento dos conhecimentos, de habilidades e de atitudes; e proporcione a organização de conteúdos atualizados, os quais instiguem o interesse dos alunos, bem como lhes possibilitem a identificação do seu significado e associação à prática profissional (MASETTO 2015b).

Analisamos e observamos uma disciplina dos seguintes professores: Abel (Crescimento e Desenvolvimento Humano), Felipe (Teoria e Metodologia do Voleibol) e Larissa (Teoria e Metodologia do Judô). De Eriberto foram duas disciplinas Adaptações Orgânicas ao Exercício e Teoria e Metodologia do Treinamento Esportivo. Nos planejamentos das disciplinas, quanto à estruturação do documento, encontramos uma forma 
padrão, consideramos que esteja relacionada à formatação institucional (Figura 16). Além disso Todos os componentes que contemplavam o planejamento apresentavam descrições específicas de cada componente curricular

Figura 16 - Componentes do plano de ensino dos professores de Educação Física jovens doutores

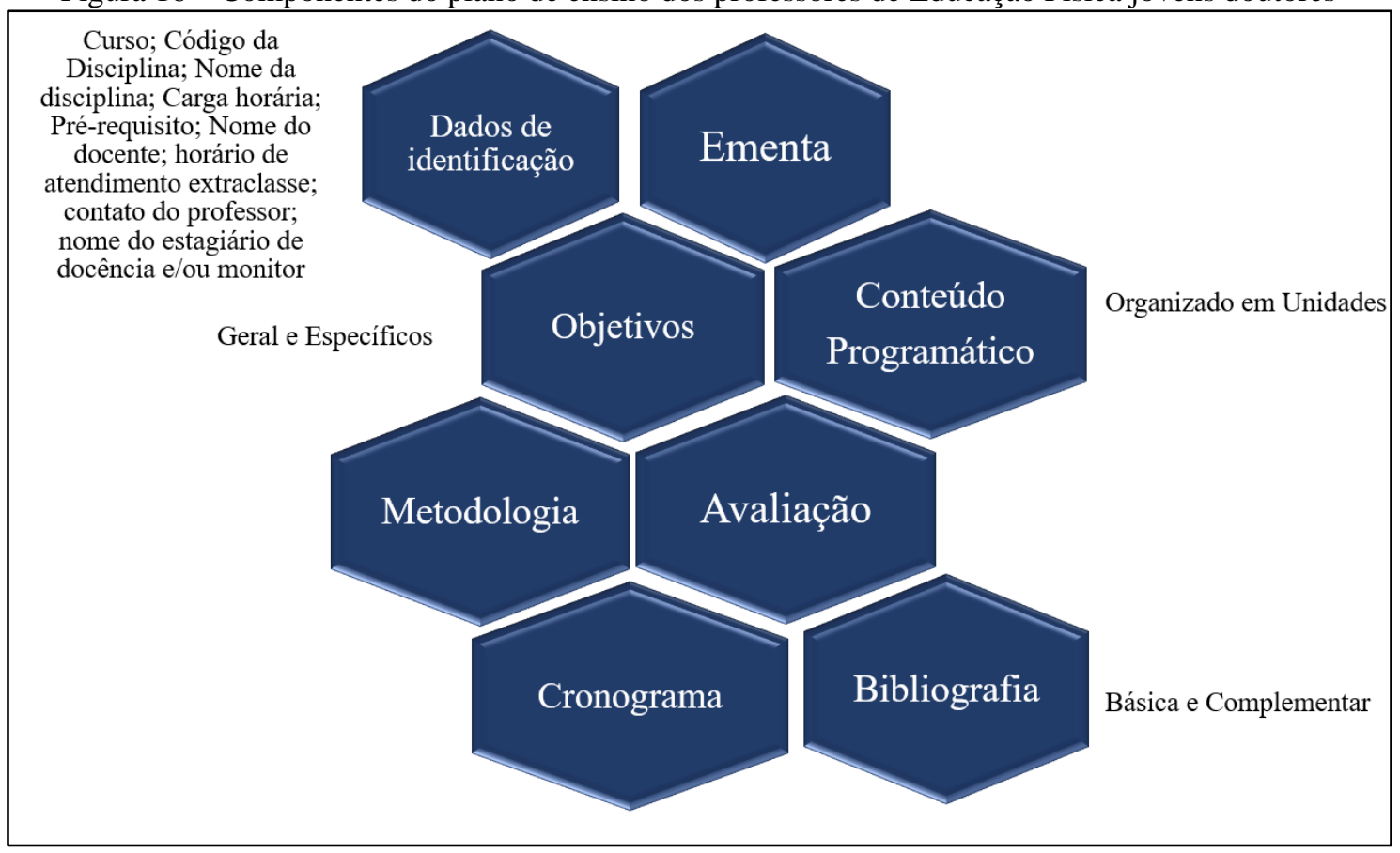

Fonte: Adaptação dos planejamentos das disciplinas dos professores de Educação Física jovens doutores (2018)

Os componentes identificados se assemelham aos apontados por Gil (2009b) e Masetto (2015a). O primeiro autor não menciona sobre ementa, enquanto o segundo alega que não há necessidade desse elemento se os objetivos estiverem bem definidos, mas muitos planos exigem todos os componentes referidos. O que se distingue, entretanto, é a nomenclatura utilizada para: metodologia (planejamento da UPC); estratégias de aprendizagem (GIL. 2009b) e técnicas (MASETTO, 2015a), mas o que é descrito refere-se à mesma abordagem: esclarecer quais são as técnicas e estratégias utilizadas pelo professor para o desenvolvimento do processo de aprendizagem. Outro componente que foi diferenciado nesse quesito de termo utilizado foi de Gil (2009b) sobre avaliação, o autor aponta como estratégias de avaliação, a fim de alcançar os objetivos propostos no planejamento.

Todos os componentes curriculares apresentavam a carga horária semestral de 72h/a correspondendo a quatro horas/aula semanais, subdividas em 54 h/a teórico-práticas e $18 \mathrm{~h} / \mathrm{a}$ de prática pedagógica como componente curricular (PPCC). Outro elemento importante para salientar nessa parte de identificação do plano foi que os professores disponibilizaram, 
aproximadamente, entre uma a quatro horas de atendimento aos estudantes extraclasse para esclarecer dúvidas. Conforme Masetto (2015a), esse tipo de atendimento auxilia na aprendizagem dos estudantes, bem como o auxilia a obter iniciativa, criatividade, curiosidade etc.

Nas disciplinas lecionadas por Eriberto (Adaptações Orgânicas ao exercício), Larissa, Felipe e Abel havia um estudante da pós-graduação (mestrado) realizando o estágio de docência. Nas aulas observadas identificamos a presença ativa do estagiário da professora Larissa nas discussões em sala e contribuições nas orientações dos trabalhos desenvolvidos em sala. Esse auxílio nas atividades desenvolvidas observamos na estagiária do componente curricular do professor Abel, mas nas discussões ocorridas em sala não realizou manifestações.

A ementa e os objetivos corresponderam às especificidades de cada disciplina, que direcionavam aos conteúdos programáticos. Todos os professores organizaram seus conteúdos em unidades, também contemplando a proposta para a PPCC, exceto Eriberto que não aponta em um dos componentes sobre essa prática. "PPCC - experiências de ensino na própria turma elou equipes de aplicação” (FELIPE); “ PPCC - ministrar uma sessão de treino com ênfase no ensino de uma técnica específica; discussão de artigos científicos (LARISSA)”; PPCC - compreende atividades de observação dirigidas e experiências de ensino fora da sala de aula - que serão distribuídas durante o semestre - leitura e redação de trabalhos científicos e reconhecimento da realidade" (ABEL); "As atividades de Prática Pedagógica como Componente Curricular - PPCC serão desenvolvidas com a ministração de aulas práticas sobre os métodos de treinamento e acompanhamento de atleta/equipe de modalidade a definir"(ERIBERTO.).

A PPCC no curso de Bacharelado em Educação Física está norteada a partir da Resolução 07/2004 (BRASIL, 2004), mas no curso de Licenciatura, além dessa normativa específica, também é norteada pela Resolução 02/2015 (BRASIL, 2015). Conforme o inciso 1 do artigo 10 da resolução específica aponta: "§1 A prática como componente curricular deverá ser contemplada no projeto pedagógico, sendo vivenciada em diferentes contextos de aplicação acadêmico-profissional, desde o início do curso" (BRASIL, 2004, p. 05). Em virtude disso, identificamos que os professores jovens doutores propõem essa prática ao longo de suas aulas, desse modo seguindo a normativa vigente.

Quanto às descrições no item metodologia nos planos de ensino, identificamos que não apresentam todas as informações que ocorrem ao longo das aulas. Na Figura 17, 
organizamo-las conforme encontramos nos planos (preto e tons de cinza) e nas aulas observadas e/ou na entrevista estruturada (branco com azul).

Figura 17 - Metodologia desenvolvida pelos professores de Educação Física jovens doutores

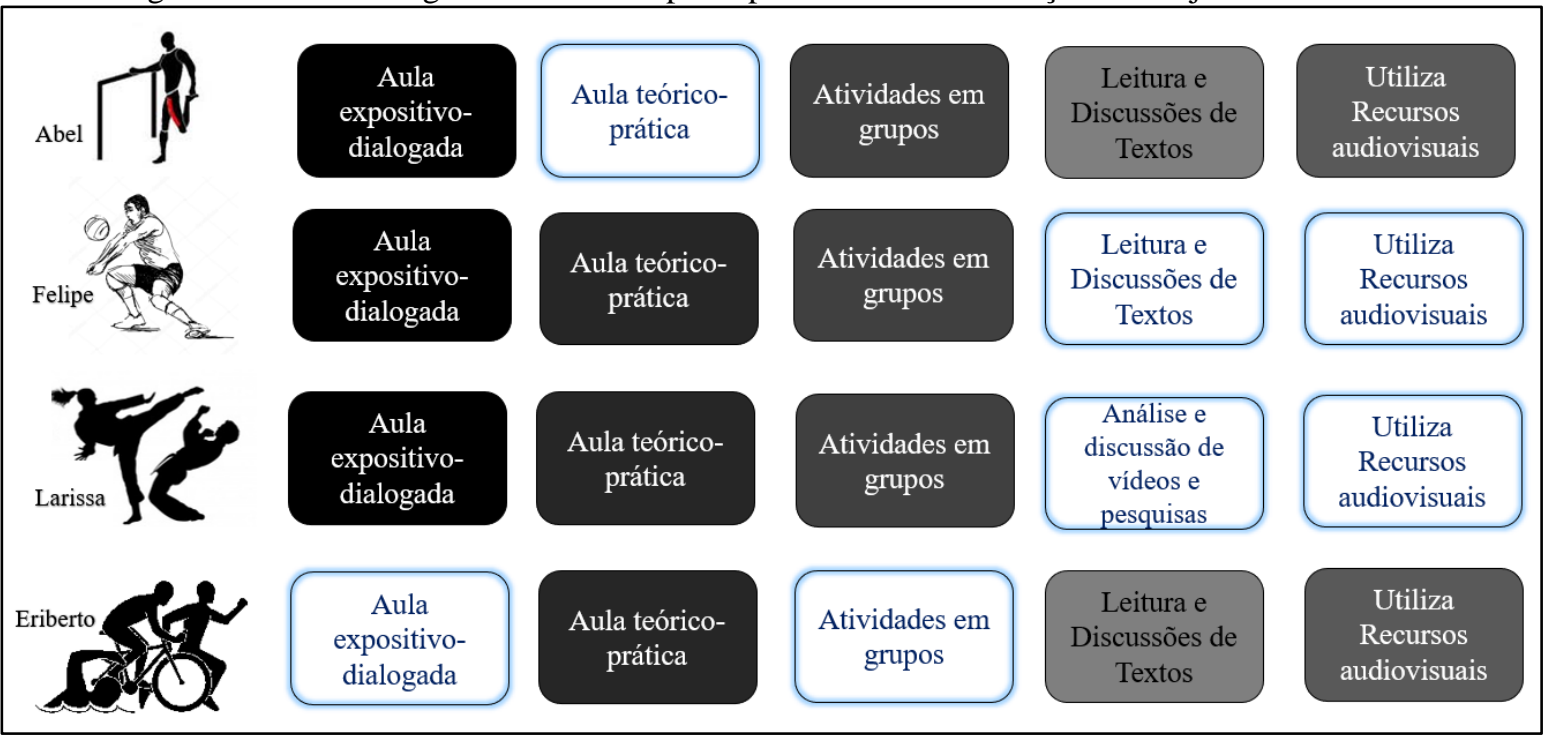

Fonte: Planos de Ensino e aulas observadas dos professores de Educação Física jovens doutores (2018)

Todos os professores desenvolvem aulas expositivo-dialogadas e teórico-práticas, entretanto Eriberto, em seu plano, aponta que ela é expositiva, mas ao longo das aulas observamos que procurou realizar o diálogo entre os estudantes a partir de colocações de perguntas e aproximações com a prática, instigando a discussão em sala. Os jovens doutores utilizavam em todas as aulas observadas questões ao longo de suas falas, as quais instigavam os estudantes a refletir sobre assunto, relacionando-o com os conhecimentos já adquiridos. "[...] Para isso tem aulas mais diretivas, aquelas que faço os questionamentos ou simplesmente deixo espaço para os comentários. Enfim, que eles se sintam livres para participação ou atividades que eles são induzidos a participação” (FELIPE).

Muitas dessas perguntas elas saem meio aleatórias, mas elas foram construídas em todo esse período [20 anos] e baseado nas expectativas que eu tenho que eles trazem de conhecimento. As perguntas ou a dosagem da pergunta está nesse conhecimento prévio que de certa forma vou detectando nos alunos. E são a partir dessas perguntas eu retroalimento naquele semestre, para eu conseguir devo aprofundar ou não. Quanto eu preciso detalhar mais ou menos determinado assunto, dar mais ou menos exemplos. Então, diria que é naquele período de aula mesmo, quando eu jogo a pergunta para eles e vou detectando as respostas naquela aula eu já consigo me trabalhar e saber se vou aprofundar mais ou menos, vou dar mais ou menos exemplos, estender mais ou menos o assunto, se já avanço mais rápido ou mais lento (ERIBERTO). 
O professor Abel não menciona sobre aula de cunho teórico-prática, mas na entrevista relata que os estudantes realizam avaliações no colégio de aplicação ou clubes de handebol, que procura aproximar os estudantes da prática à parte do PPCC. A partir de sua narrativa, identificamos que o docente encontra dificuldade em aproximar as questões teóricas e as práticas, causadas pela grade curricular fechada; estudantes que cursam componentes em diferentes fases; e o curso poderia proporcionar mais vivências práticas. Também relata que os estudantes precisam se aproximar das práticas para melhorar a sua atuação profissional.

\begin{abstract}
[...] curso poderia evoluir bastante se nós proporcionássemos que os alunos estivessem mais na vivência prática de todos os campos. E eles teriam mais para dialogar com a gente. Tem a questão teórica, mas tem a questão prática também que é importante. Antigamente tínhamos muitas vivencias práticas e poucas teorias e agora a gente inverteu um pouco isso, está com muita teórica e deixando as questões práticas de lado. Então nós vamos para um lado que também não é interessante, que tem professores bons que não vivenciaram nada. Não estou dizendo que eles têm que jogar, ser tecnicamente perfeito, mas eles precisam conhecer os ambientes, pois o ambiente do voleibol é diferente do ambiente do basquete, diferente do handebol [...] (ABEL)
\end{abstract}

A professora relata que para alguns conteúdos das aulas práticas não consegue encontrar uma estratégia diferente da tradicional, pois ela preza pela segurança do aluno. Tal situação não a deixa confortável, reconhece essa dificuldade de mudança, mas quando consegue realizar algo diferente há uma boa receptividade perante os estudantes.

\footnotetext{
Tem alguns momentos que sou bem diretiva e tradicional, porque tem técnicas que requerem bastante segurança, então acima de tudo estou ali para garantir a segurança dos alunos [...] então tem momentos que sou bem tradicional mesmo, mas não gosto, para mim são as piores atividades. Por exemplo, quando eu ensino quedas, eu acho que fica muito repetitivo, mas também garante a segurança e isso vem acima. Mas quanto mais eu consigo diversificar as atividades eu percebo que há um envolvimento maior, mais interesse, é difícil seguir um método. Eu acredito que depende do que vai ensinar tentar uma maneira ou outra [...] (LARISSA).
}

Ao longo das aulas observadas, até mesmo nas entrevistas, identificamos que os professores buscam aproximar a teoria da prática em suas discussões. $\mathrm{O}$ resgate das experiências esportivas, profissionais até mesmo familiares foram citadas pelos docentes. Também verificamos que utilizam dos recursos tecnológicos para essa aproximação, a partir de vídeos e figuras. A professora Larissa menciona que trouxe um especialista em defesa pessoal para conversar sobre esse assunto e trazer algumas questões da prática aos estudantes. 
acadêmico, ele é mestre em Defesa Pessoal [...] foi uma experiência bem interessante, mas foi uma experiência mais para vida do que para parte acadêmica. Mas acho que os alunos gostaram, foi uma coisa diferente. A violência está em qualquer lugar, não está só nos lugares mais pobres ela pode acontecer em qualquer lugar (LARISSA).

tem muitas coisas que eu consigo ver na prática, até eu levo os exemplos da minha filha para a aula. A curva de crescimento, até porque é real, eu consigo explicaro que aconteceu os reflexos e isso é interessante. Tem coisas que não estão escritas nos livros, isso todos sabem. [...] Às vezes, nós damos um diagnóstico de crescimento que nem sempre é tão alarmante, então comecei a trabalhar na disciplina que eu vivencio (ABEL).

Então a gente tentar pegar o que a gente discutiu em texto e chega no ginásio tento colocar em situação. A dificuldade maior de associar a teoria e a prática, às vezes, você não tem a condição prática da mesma realidade (FELIPE).

Ao analisarmos as doze aulas, identificamos que, habitualmente, os professores realizam a chamada no início da aula e ao final conversam com os estudantes esclarecendo algumas dúvidas sobre o conteúdo abordado na aula e/ou atividade a ser realizada. Todas as aulas dos jovens doutores foram organizadas no mínimo em duas partes e no máximo quatro. O resgate da aula anterior e a explicação da próxima aula foram identificadas ao menos uma vez em cada professor, a professora Larissa o realiza ao longo do seu diálogo durante as aulas. A participação efetiva dos estudantes durante as aulas foi também identificada a partir das discussões dos trabalhos desenvolvidos e/ou questões propostas pelo docente, além disso os professores solicitaram tarefas para desenvolverem em casa. Também o feedback após as perguntas realizadas pelos estudantes aos professores proporcionava um feedback positivo, ficando mais evidenciado nas aulas de Abel e Felipe. Na figura 18 sintetizamos a organização das três aulas observadas dos jovens doutores.

Eu penso que em uma continuidade a forma que eu construo o conhecimento que eu quero transmitir ele é sequencial e continuo. Então assim, mais do que simplesmente dar uma palestra, não necessariamente elas se relacionem a tendência é essa: quando eu termino uma aula, se eu pudesse eu ficava dando a aula as quatro seguidas ali para dar essa continuidade, mas é obviamente não seria bom para ninguém (ERIBERTO)

Eu procuro sempre montar as aulas de uma maneira que os alunos possam participar sempre, esse é o principal pontos das minhas aulas. Em alguns conteúdos isso acontecem mais outros acontecem menos, em função do que está sendo dada. Eu sempre procuro pensar em formatação de aula que o aluno o direito e oportunidade de opinar, parte dele passar suas experiências $e$ contribuição (FELIPE).

o primeiro momento eu penso dar conteúdos mais básicos, de certa maneira, mas eu vou inserindo nesses conteúdos mais básicos informações mais específicas, conteúdos práticos. Exemplo: vou trabalhar iniciação esportiva, mas já começa inserir os movimentos da iniciação esportiva. Então eu tento mesclar sempre uma aula teórica e uma aula prática, tentar puxar o que dei na aula teórica na aula 
prática, assim não fica aquele bloco de aula teórica, aquele bloco de aula prática e que não se conectam.

Agora é intencional o feedback, antes não. Eu via muito a professora [nome] fazer isso, porque o aluno se sente importante, quando você dá um feedback positivo. Depois eu comecei a perceber que funcionava, principalmente para as pessoas tímidas. Tem pessoas que tem dificuldades para perguntar na sala, então quando essas pessoas perguntam, procuro dar um feedback mais positivo, reforçar aquela colocação para e se sinta bem [...] aro que as vezes eu faço um reforço negativo também, mas de forma sutil, faço, normalmente, naqueles alunos que querem falar sempre e acham que podem falar tudo. Não filtram, mas hoje eu faço mais intencionalmente essas coisas (ABEL).

Figura 18 - Organização das aulas observadas dos professores de Educação Física jovens doutores

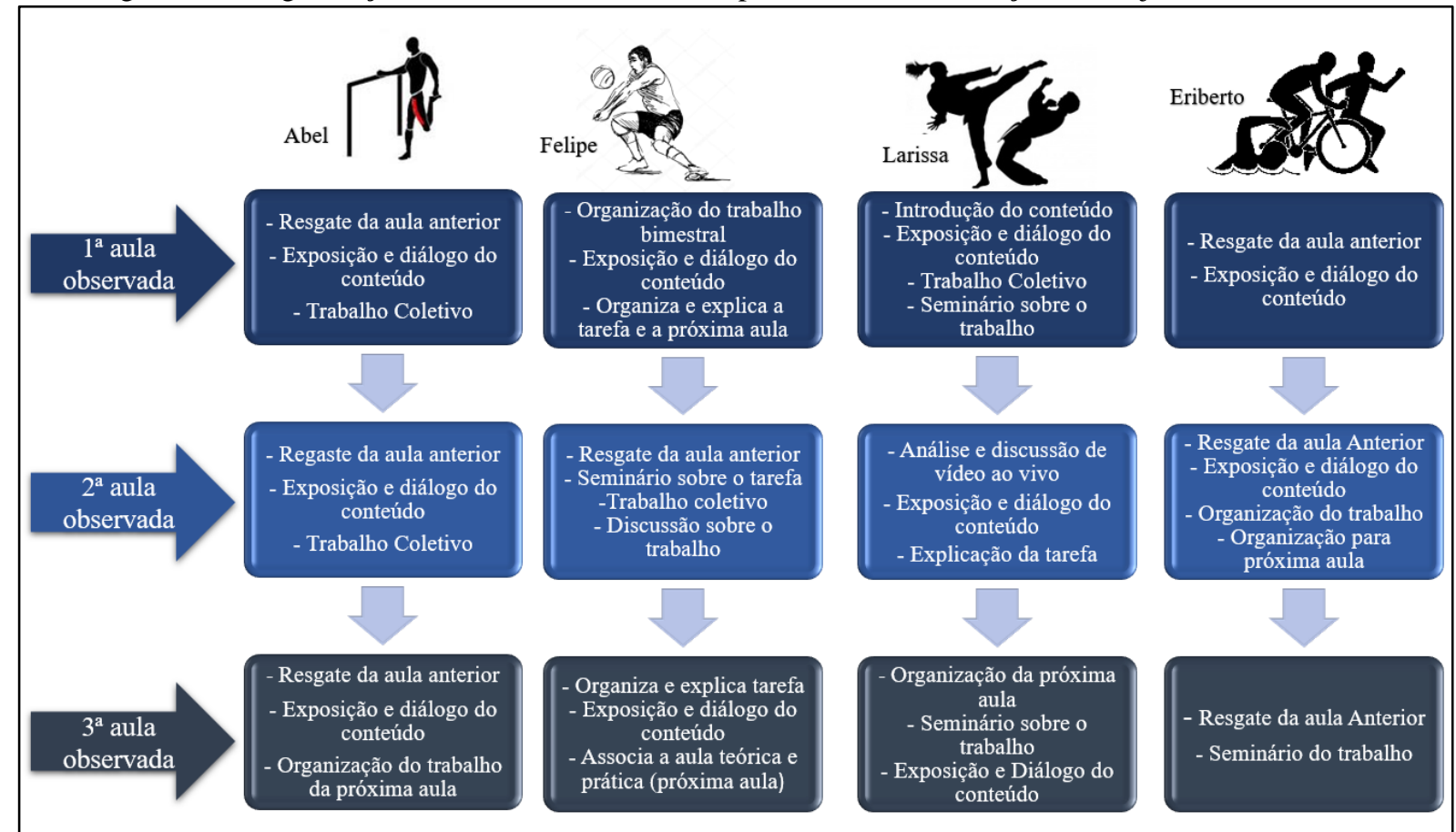

Fonte: Aulas observadas (2018)

As atividades em grupo foram mencionadas no plano de ensino de Abel, Felipe e Larissa, enquanto Eriberto não fez esse apontamento. A mesma situação foi encontrada na descrição sobre atividades relacionadas à leitura e discussões de texto, citadas apenas por Abel e Eriberto, mas observamos que ocorreu na aula de Felipe. Nas aulas observadas identificamos que os trabalhos coletivos foram desenvolvidos por todos os jovens doutores, os quais considerados como avaliação do conteúdo abordado. As atividades proporcionaram aos estudantes o resgate dos conhecimentos desenvolvidos nas aulas anteriores, naquela aula e/ou conhecimentos já adquiridos ao longo das suas trajetórias formativas.

Entre as aulas observadas de Abel, identificamos que o docente realizou duas atividades dentro da sala referentes ao conteúdo abordado. Na primeira aula observada, separou a turma em trios, os quais deveriam fazer uma síntese do que foi discutido durante a 
aula, o professor estipula o tempo de 20 minutos. aponta que podem colocar o que quiserem e não precisa fazer rascunho. Enquanto isso o docente e a estagiária mestranda foram passando nos trios, tirando algumas dúvidas pontuais. Quando deram 20 minutos, o professor pediu para os estudantes pararem o que estavam fazendo, apontando que esse foi o tempo combinado. Pede para os estudantes colocarem o nome na folha, rodarem a folha à direita, e o grupo que recebeu colocar o nome e colocar que receberam. Explica como procederá a próxima aula: "aquele grupo que recebeu o trabalho terá 10 minutos para analisar e acrescentar as informações que acreditam estar faltando, depois irão discutir" (ABEL).

Na segunda aula observada: conforme o que foi explicado na aula anterior, o Professor separa em duplas e, a partir da tabela exposta, teriam que desenhar um gráfico utilizando a idade cronológica em que vai acontecer o pico de crescimento. Ao longo da atividade, o professor foi passando nas carteiras para auxiliar os estudantes a construírem os gráficos. Os estudantes apresentaram algumas dificuldades, pois se depararam com alguns problemas, o professor aponta: "Pessoal, preciso que vocês parem e reflitam para solucionar o problema, se eu falar, fica muito fácil, mas irei explicar mais algumas coisas!" (ABEL). O docente fez novamente a explicação e disse que teriam que procurar a resposta do problema, mas continuou passando nos grupos. O professor aponta que essa atividade será utilizada na próxima aula e deveriam terminar em casa no Excel. O exemplo da atividade estava disponibilizado no sistema Moodle, e mencionou que no começo da próxima aula iria sortear alguns dos estudantes para apresentar. Por fim, perguntou se ainda tinham mais alguma dúvida.

E na terceira aula observada, novamente resgatou a discussão da aula anterior, prosseguido na exposição e diálogo do conteúdo, proporcionando questionamento aos estudantes. Ao final da aula organizou o trabalho para apresentação na aula seguinte.

Quanto às leituras, Abel, na primeira aula observada, relata sobre a importância de os estudantes lerem o material disponível no sistema Moodle antes de virem à aula, pois auxilia na compreensão do assunto que está sendo abordado e desenvolvido das atividades propostas. Na entrevista menciona que, ao longo da docência, identifica que esse procedimento auxilia na aprendizagem dos estudantes, mesmo que não tenha ocorrido $100 \%$ e/ou realizado anotações. $\mathrm{O}$ docente reconhece que muitos estudantes não realizam as leituras por diferentes motivos, mesmo que o material esteja disponível em tempo hábil e que ocorra diversificação de material sobre a temática da disciplina desde cunho científico como reportagens, textos de blogs dentre outros. Na perspectiva de Abel, para que essa estratégia dê certo, a avaliação precisa detectar aquele aluno que lê ou não entendeu o assunto, mas isso não aconteceu. $\mathrm{Na}$ 
entrevista, o docente faz uma relação sobre as atividades em grupo, as dificuldades dos estudantes e a importância da leitura.

\begin{abstract}
Eles vêm com dificuldade de entendimento, não seria dificuldade, mas eles não querem pensam muito sobre a resposta. Eles querem que eu de a resposta diretamente para eles das perguntas que eu faço. Eu instigo eles, olha: pensa e desenvolve seu raciocínio. Acho que o material didático se fosse lido antes poderia tirar uma boa parte dessas dúvidas que eles têm. Além disso, eu procuro colocar os slides das minhas aulas no moodle, para que consigam seguir o que estou abordando ao longo das aulas, isso é bom e ruim. Às vezes, eles só seguem os slides e deixam de ler o conteúdo, isso eu tenho reavaliado, sobre a importância disso. Retornar o conteúdo e explicar de uma outra forma é uma coisa que tenho feito. E eu tenho feito algumas estratégias quando eu vejo que a turma não entendeu: é no final das aulas eu peço para eles fazerem um texto ou gráfico sobre aquele conteúdo, e tenho identificado quem consegue fazer e replicar, colocar no papel o que eu expliquei o que a gente estava discutindo na aula. Se eu vejo que não conseguiram entender, eu volto na aula outra aula, porque eu vi que a maioria não entendeu $(A B E L)$.
\end{abstract}

Também identificamos que na primeira aula observada o professor Felipe aborda sobre a realização das leituras solicitadas e que naquela disciplina ele não solicitava muitas, mas as sugeridas deveriam ser lidas. Naquele momento os estudantes questionaram o professor, pois ele tinha disponibilizado pouco tempo para leitura. O docente fez sua contraposição sobre a dedicação aos estudos e colocar algumas prioridades em sua rotina. Apesar desse posicionamento, o docente alega que, embora as aulas dele apresentem um número elevado de práticas, os estudantes conseguem entender a importância da leitura e não tem um pré-julgamento sobre isso. A mobilização de Felipe por tal insistência com estudantes está relacionada a uma base na formação profissional.

\footnotetext{
[...] não basta pensar só no específico do objetivo da disciplina. Tem que ter algo em geral que acaba refletindo em tudo. Se você faz uma casa e não faz uma base bem-feita ela vai cair. Então as competências básicas têm que vir [...] estava até discutindo com os professores no almoço: "alguns alunos vem dizendo que já sabem isso que não tem muito o que aprender!" E esses alunos que vem com esse pensamento será uma pessoa limitada. Não estará disposto sempre aprender, significa trocar ideias (FELIPE).
}

As leituras solicitadas por Felipe foram um artigo científico e um capítulo de livro, os estudantes deveriam realizá-las em casa e responder três questões referentes ao primeiro texto. Na segunda aula observada, o professor resgatou as perguntas que deveriam ser respondidas a partir do texto lido e fez uma relação com o assunto abordado na aula anterior. Em seguida perguntou quem tinha lido os textos e poucos se manifestaram, então expôs a primeira pergunta no retroprojetor e questionou novamente os estudantes para iniciar a 
discussão. Assim seguiu essa primeira parte da aula e ao final recolheu as questões respondidas. No segundo momento da aula disponibilizou mais três questões sobre o capítulo do livro, em duplas os estudantes deveriam escolher uma das perguntas para responderem em sala e o resto poderia ser desenvolvida em casa. O professor estipulou o tempo de 20-25 minutos para responderem, enquanto isso foi passando nas duplas e esclarecendo as dúvidas. Após encerrar o período estipulado, Felipe discutiu um pouco sobre o texto, depois sorteou um número da chamada e perguntou sobre o que foi discutido na dupla e assim por diante. Os estudantes puderam levar as questões para cara e arrumá-las para entregar na próxima aula (tarefa 1$)$.

Na terceira aula observada de Felipe, identificamos, sobre a tarefa 1 as correções e lançamento de notas. Em seguida, explica sobre a tarefa 2, que deveria ser realizada em trios, os estudantes teriam que fazer uma pesquisa nas bases de dados, nem todos os estudantes sabiam como fazê-la, o professor explicou o que são bases e como buscar. A atividade deveria ser realizada a partir de palavras-chaves: o mínimo será voleibol, mas como aparecerá muita coisa, as demais ficarão a critério de interesse dos estudantes. Depois da pesquisa poderia conversar com o Monitor da disciplina, ele ajudaria na organização e seleção dos artigos, os quais deveriam ler e depois apresentar. O professor perguntou aos alunos: vocês conhecem o que é artigo científico? (FELIPE), em seguida, explica o que seria. O docente relata sobre a importância da interpretação de texto e a necessidade de uma análise crítica, mas de forma cortês.

As avaliações realizadas por Felipe são diversas, procura desenvolvê-las de modo que o estudante que não participe sinta falta desse envolvimento. Também considera que a prova ainda é uma avaliação que reflete mais a participação do aluno, em virtude disso, busca construir questões que façam o estudante pensar e refletir.

Eu tenho avaliações bem variadas, se você for olhar os planos de ensino lá. [...] a prova teórica ainda acaba sendo que reflete mais a participação do aluno, apesar de ser uma prova. Eu tento fazer perguntas mais elaboradas que eles têm de pensar, refletir, tento conduzir dessa forma. Por outro lado, tem avaliações diretamente relacionada a participação, exemplos: leitura de texto e discussão em sala - eles têm que ler aquilo e escrever uma resposta e será trabalhado em cima daquilo [...] Não costumo mudar o que vou avaliar, o que vejo que as avaliações nem sempre saem como desejadas conforme a turma. Obviamente algumas adaptações acabamos fazer, nas discussões que não aprofunda tanto, acaba limitando. Adaptações faço, mas mudança não (FELIPE).

O professor Eriberto menciona sobre o trabalho em grupo, leituras de textos e discussões, mas identificamos, ao longo das aulas observadas, apenas a primeira forma de 
avaliação. Na primeira aula não identificamos uma avaliação a partir de atividades, realizou uma aula expositivo-dialogada realizando questionamento aos estudantes a fim de estimular a participação e reflexão. Na segunda aula identificamo-lo explicando uma atividade aos estudantes, os quais deveriam construir, em duplas, uma sessão de treinamento intervalado como se fosse na prática. O docente colocou toda explicação da atividade no slide e fez a seguinte pergunta:" vocês conseguem se organizar amigavelmente pelos objetivos de treino?” (ERIBERTO). Os estudantes dizem: "não" (ESTUDANTES). Então realizam um sorteio e o professor foi organizando em uma planilha no computador onde foi colocando os nomes das duplas. O prazo de entrega do treino seria na próxima aula, a qual também observamos. Na terceira aula de observação o professor perguntou se os alunos apresentavam alguma dúvida sobre a construção do treino, em seguida, abriu uma planilha, a mesma em que organizou as duplas. Conforme os estudantes foram discutindo os treinos construídos, Eriberto foi inserindo as informações do treinamento na planilha. Ao longo das discussões o docente realizava questionamentos aos estudantes que construíram o treino e aos demais alunos ouvintes, a fim de proporcionar uma reflexão e construção crítica sobre o material elaborado. Ao encarrar a atividade, apresentavam 10 variações de treino intervalados e o docente alega: "hoje vocês fizeram 10 tipos de treinos intervalados, não precisam ficar centrados naqueles treinos que colocam nas paredes de academia etc." (ERIBERTO).

A professora Larissa não faz menção sobre atividade de leitura, mas realiza análise de vídeos e dados de pesquisa de dados e, em seguida, discute com os estudantes, além disso usufrui da tecnologia para o desenvolvimento dessas atividades. Na primeira aula observada, a docente divide em equipes de quatro os estudantes para realizarem atividades sobre judô para adultos iniciantes. A professora estipulou 10 minutos para o desenvolvimento da atividade, também auxilia os estudantes a se organizarem, pois estavam meio confusos. Uma equipe formou-se com sete estudantes, a professora abordou a equipe e disse que poderiam ficar, mas iriam fazer duas atividades. Ainda a professora deu mais alguns exemplos e iniciaram a atividade. Após o esgotamento do tempo estipulado, a professora solicitou-lhes que se organizassem em círculo para discussão das atividades desenvolvidas. A primeira equipe iniciou a explicação, justificando que utilizou como base para construção da atividade as aulas práticas desenvolvidas até o momento. A professora realiza algumas perguntas, por exemplo, como poderia ser a execução etc., se a turma concorda sobre o que foi dito pela equipe e professora, assim prosseguiu a atividade. Larissa sempre escutava a explicação dos estudantes, depois complementava e fazia alguma pergunta para auxiliar na 
reflexão sobre a atividade desenvolvida, estimulando a discussão e participação de todos os estudantes.

$\mathrm{Na}$ programação da segunda aula observada, a professora realizou algumas adaptações do que estava previsto para discussão, pois no horário da aula estava ocorrendo um campeonato internacional de judô e transmitido pelo YouTube. Então colocou a luta da judoca brasileira para os estudantes assistirem ao vivo, e questionava as posições das atletas e decisões do árbitro com os estudantes. Os alunos interagiram e gostaram do que estava acontecendo quando a professora analisou outras lutas que estavam ocorrendo. Depois realizou a atividade que estava programada, para finalizar a aula a professora deixa uma tarefa para ser realizada em casa: uma atividade sobre cada unidade funcional discutida na aula. Na entrevista questionamos a docente sobre essa estratégia utilizada:

Foi bem ao acaso, que naquele momento iria passar no YouTube, pois eu queria mostrar um vídeo o que eu queria explicar [na aula]. Mas vamos ver o vídeo, já que tinha brasileira. Eu quero acreditar que eles queriam assistir um vídeo porque eles estavam gostando. Então, aquilo de alguma maneira estava instigando o gosto pelo esporte, de ver como é o esporte competitivo de alto nível. Eu quero acreditar que essa foi a razão, não que eles queriam matar aula. Eles ficaram bem animados, faziam perguntas, estavam interessados. Foi mais válido que o que vídeo, e foi até para mim, pois não fazia ideia do que iria acontecer. Na primeira luta foi muito chata, não acontecia nada, a outra luta foi mais interessante. Mas de ver isso na hora e poder analisar achei bem interessante, para mim e para eles. Também considero que chamou mais atenção que um vídeo (LARISSA).

Na terceira aula observada, a professora Larissa foi sorteando os alunos conforme a chamada e eles teriam que apresentar a atividade construída em casa referente à unidade funcional. Dessa forma a docente foi questionando a turma, instigando a discussão e a reflexão da atividade que propusera. Encerrou a discussões e iniciou um novo assunto sobre o treinamento físico do judô, utilizando slides, faz uma pergunta sobre: "quais são as lutas de média distância?" (LARISSA). Ao longo da aula coloca situações problemas da prática, utiliza também um programa de como analisar a luta e como devem analisá-la. A professora apresenta estudos que discutem sobre questões físicas no judô, e passa alguns dados encontrados em seu estudo desenvolvido no mestrado sobre potência do chute do membro inferior, também utilizou dados de outros estudos publicados em artigos científicos.

Ao explanar sobre avaliação dos atletas, Larissa colocou uma pergunta no slide: Por que avaliar os atletas? Houve um aluno que respondeu, mas logo a professora iniciou a explicação. Depois outros alunos foram perguntando e tirando dúvidas. O monitor da disciplina também complementou os exemplos juntamente com a professora. Foram mostrados alguns testes que são utilizados, apresentados a partir de vídeos, apontando a 
frequência utilizada e reconhecimento. Nessa parte os alunos discutem bastante, junto com a professora, como analisar o movimento etc.

Os recursos audiovisuais que identificamos ao longo das aulas foram: o computador e o datashow em todas as aulas, mas usufrui da lousa e caneta para auxiliá-los a explicar o assunto abordado. Todos os jovens doutores projetaram slides, utilizando o programa Powerpoint da Microsoft, neles continham figuras, texto, esquemas e pequenos vídeos. $\mathrm{O}$ programa word da Microsoft também foi encontrado, com menor frequência, apenas para mostrar a organização de alguma atividade proposta. $\mathrm{O}$ professor Eriberto utilizou o programa excel para construção do plano de treinamento intervalado desenvolvido pelos estudantes. Larissa reproduziu vídeo ao vivo de um campeonato de judô. Organizamos alguns exemplos que identificados durante as aulas a partir das Figuras 19 a 22. Além desses recursos audiovisuais também identificamos outros recursos como o sistema moodle, disponibilizado pela instituição, capítulos de livros, artigos científicos, base de dados, papel, caneta e régua.

Figura 19 - Utilização de recursos audiovisuais por Abel

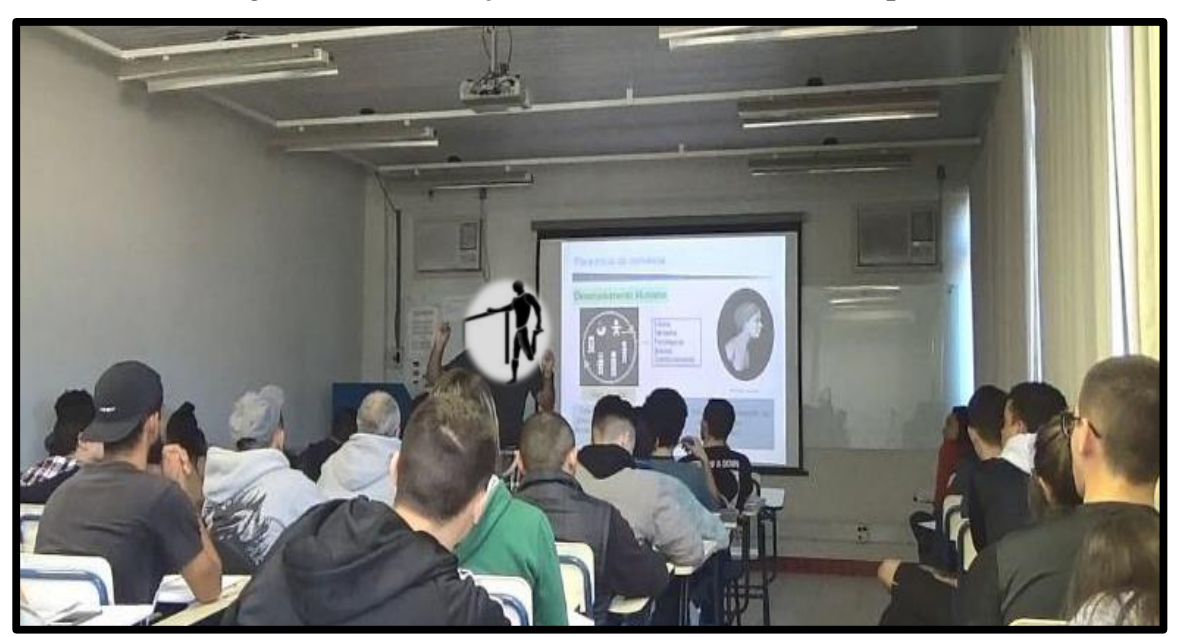

Fonte: Aula observada de Abel (2018) 
Figura 20 - Utilização de recursos audiovisuais por Larissa

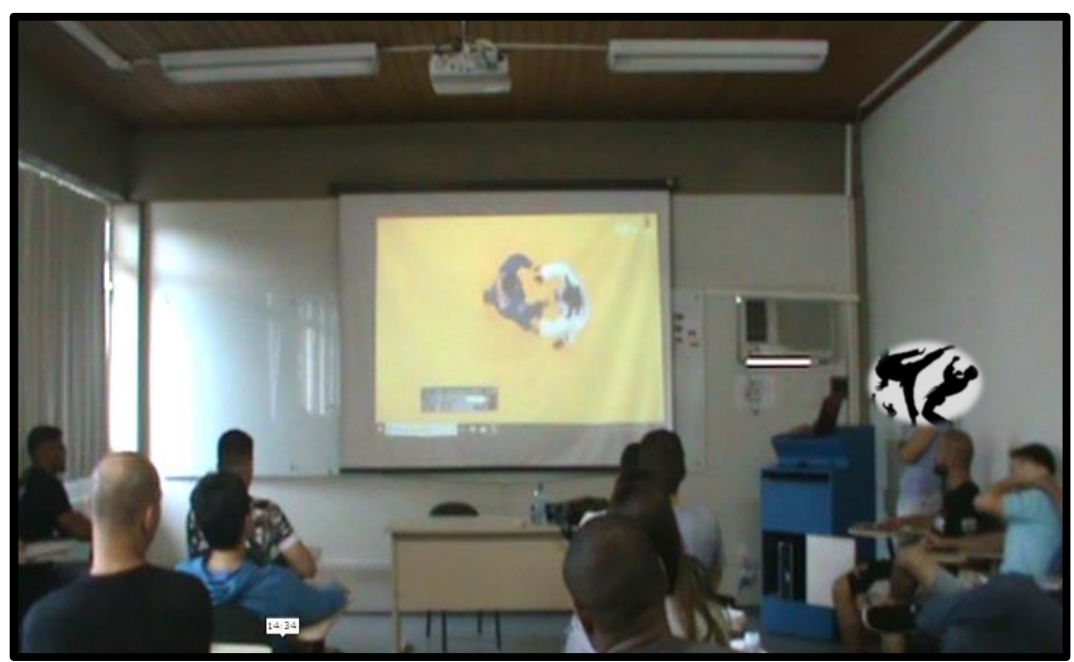

Fonte: Aula observada de Larissa (2018)

Figura 21 - Utilização de recursos audiovisuais por Eriberto

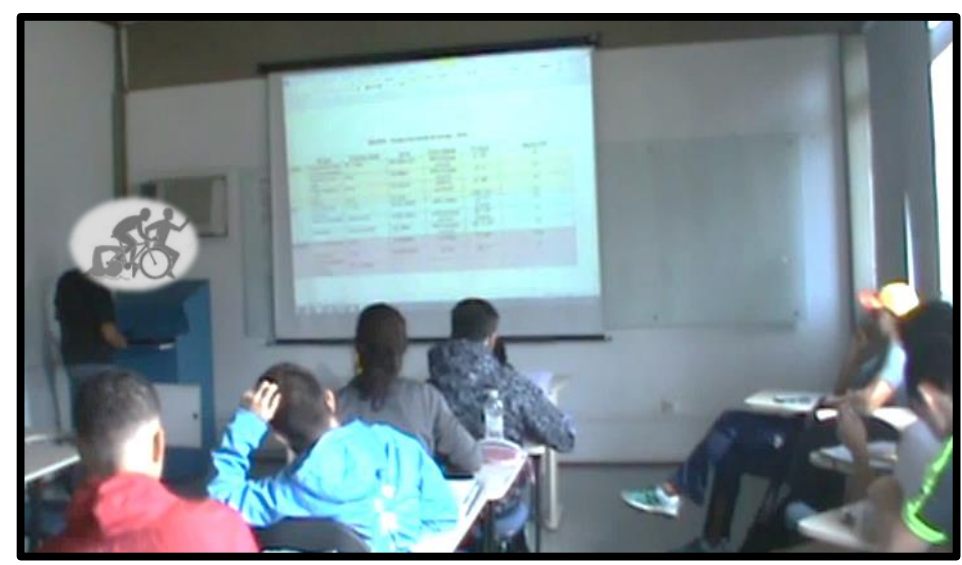

Fonte: Aula observada de Eriberto (2018)

Figura 22 - Utilização de recursos audiovisuais e lousa por Felipe

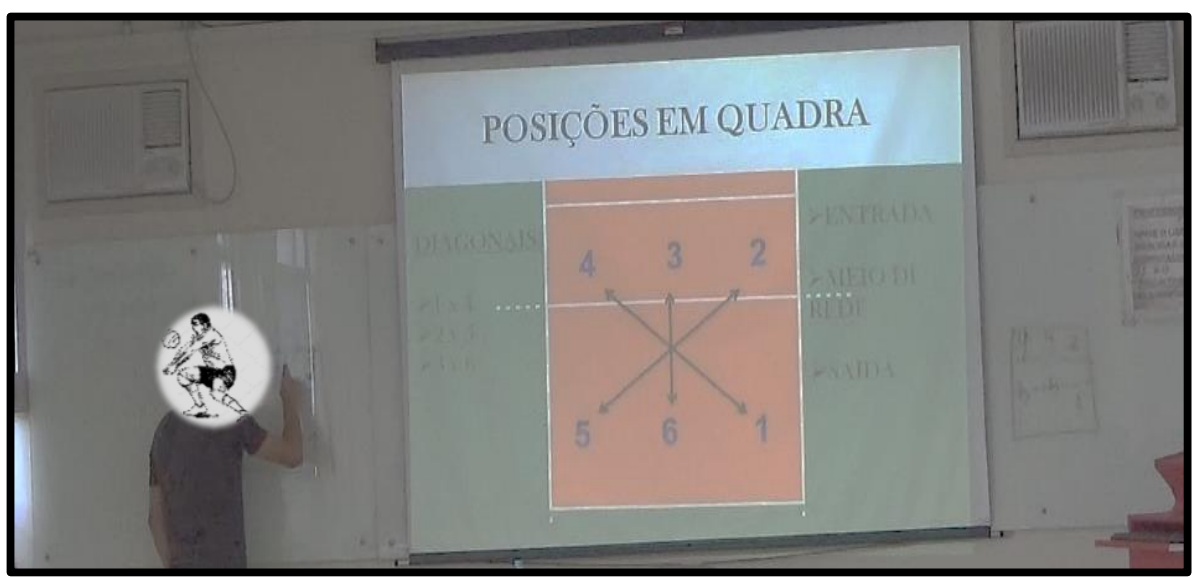

Fonte: Aula observada de Felipe (2018)

A partir disso verificamos a presença significativa da tecnologia digital nas aulas dos jovens doutores. Sobre essa questão os professores abordam mais sobre esse uso em suas 
aulas e a contribuição para a prática pedagógica. O professor Eriberto, embora seja um jovem doutor, ainda apresentou ao longo da sua trajetória docente a vivência da fase que habitualmente os professores mais velhos utilizavam durante as aulas: o quadro, retroprojetor, a transparência e o datashow. Alega que, sem dúvida, a tecnologia atual e a facilidade de acesso às informações contribui muito na prática pedagógica, possibilitando a proximidade com a prática. Além disso, a instituição proporciona equipamentos de última geração em seus laboratórios, possibilitando o processo de aprendizagem e a relação teoriaprática.

Eu tenho usado muito moodle e tenho me dado bem, o que uso lá: Uso vídeos, tenho preferido usar mais vídeos do que textos, porque, por exemplo: tenho um vídeo que eu trabalho com um documentário - muito além do peso - trabalha a questão da indústria alimentícia e a obesidade e no final dele tem uma questão, tem uma criança para gastar mil calorias precisa nadar duas horas e meia [...] os fóruns, eu trabalho, eu coloco uma reportagem e falo para colocarem sua opinião sobre o que você pensa sobre isso. Assim vai seguindo e vai discutindo e eu vou interagindo. Todas essas atividades eu pontuo, se não eles não fazem. Mas as novas tecnologias que temos são muito importantes, elas vão ajudar significativamente, considerando que os alunos que temos hoje quer isso, ele não quer ficar lendo (ABEL)

Elas são importantes, hoje em dia não conseguimos mais viver sem eles. $O$ importante que eu comecei usar a pouco tempo... o moodle tem várias ferramentas e pouca gente usa, pois nós não temos conhecimento. Não é por falta de curso, sempre tem curso. Uma coisa que aprendi lá: os alunos têm que controlar suas faltas no moodle, parece bem bobo, mas eles têm que ter responsabilidade além de ir para aula e levar seu caderno e seu lápis [...] Quando você coloca no meio digital, está publicado lá e você tira sua responsabilidade [...] tem outras coisas também, mas tenho que pensar melhor para elaborar: o chat, por exemplo, acho que é interessante, mas tenho que ver como vou adequar na disciplina (LARISSA).

[...] tudo que é coisa nova é bem-vindo. Eu sou muito dos dois lados, tem gente que não sabe dá aula sem o powerpoint, tem gente que diz: "Professor bom é aquele que dá aula no quadro com giz!". Acho que tudo que você possa utilizar que seja proveitoso para sua aula ser melhor, escrevendo em um quadro, se for um vídeo ... Eu não tenho resistência para coisas novas, bem como não acho o novo ou o melhor o velho. Mas o que eu uso não tem muita novidade: vídeos, hoje não precisa mais de tv, faz projeção no próprio projetor do Datashow. Então tem a internet se você quiser baixar um vídeo no YouTube e mostrar metade de uma partida você baixa, temos a internet conectada e isso facilita bastante (FELIPE).

[...] essa perspectiva desse período que eu dou aula sem dúvida os recursos tecnológicos agregaram muito e facilitaram muito, principalmente a forma de acessar a informação hoje. Hoje na disciplina fisiologia que eu consigo carregar vídeos de reações celulares no slide que eu tenho mesmo consigo executar um vídeo que poderia ser inimaginável até uns 15 anos atrás para mim. Eu não tinha acesso essa tecnologia, hoje sim, qualquer coisa acesso os diferentes vídeos possíveis e escolho que é mais didático e adequado. Enquanto recursos didáticos áudio visuais eu diria que eu estou muito bem servido, sabendo usar você tem muita possibilidade de dinamizar até e não ficar lá no slide com texto texto texto [...] Como no laboratório hoje nós temos equipamentos de tecnologia avançada onde a gente faz aula, conseguimos medir o consumo de oxigênio, lactato, até a própria bicicleta que a gente usa que me torque, são recursos bem avançados eu 
diria [...] temos os mesmos equipamentos que qualquer laboratório no mundo tem. Nesse lado prático consigo trazer para os alunos.

$\mathrm{Na}$ entrevista estruturada, questionamos os professores se o plano de ensino é construído de forma individualizada ou juntamente com seus pares, além disso se buscam realizar atividades junto com outros componentes curriculares. Todos os jovens doutores relatam que realizaram conversas entre docentes de outras disciplinas que apresentam conteúdos próximos e complementaras para organização dos conteúdos abordados; durante as aulas procuram realizar aproximações com assuntos de outras disciplinas e reconhecem a importância de realizarem trabalho em conjunto. No entanto Larissa e Abel apontam que a ementa vem pronta, então seus conteúdos estão organizados a partir dela, havendo poucas alterações. Os docentes Larissa e Felipe apontam, nesse período que estão lecionando na UPC, já realizaram atividades em conjunto com outros componentes, mas no momento não realizaram.

\footnotetext{
Varia bastante, semestre passado tem a disciplina de primeiros socorros [...] que fizemos uma atividade em conjunto, tem a parte de avaliação física no voleibol. Essas demandas de jogos e lesões no voleibol. A Professora [nome] quis dar aula de como proceder em caso de lesões: torce o tornozelo por exemplo etc. Às vezes, também nas aulas de biomecânica, trazendo exemplos de situações que eu trabalho. Da disciplina de fundamentos didáticos também. São práticas que já ocorreram, mas não ocorrem sistematicamente (FELIPE).
}

Plano de ensino eu construí baseado na ementa, mas já tivemos cooperações. Por exemplo, na disciplina de Emergência - Primeiros Socorros - a Professora [nome], ela tinha uma atividade que cada grupo tinha que apontar as principais lesões em cada esporte. Então tinha um grupo das lutas, eles fizeram uns folders com as principais lesões que ocorriam no judô, quais as causas, quais medidas tomar na hora do acidente. Eles também vieram conversa com a turma, reservei meia hora para eles falarem com os alunos. Achei bem interessante, não era um conteúdo da ementa da disciplina, mas estava relacionado. Também fizemos alguma coisa, mas ficou mais na base da conversa sobre o judô para cego, paraolímpico. Eu quero ver se trago algo mais sobre isso, pois meu aluno está estudando. Eu sei que tem uma disciplina específica para esporte adaptado [...] considerando que eles já conhecem a olímpica, discutir o que muda para paraolímpica. Acho que é uma coisa que poderia explorar mais (LARISSA).

Quanto às condições de os estudantes correlacionarem o conteúdo das suas disciplinas com outro componente curricular foi unânime entre os jovens doutores, há dificuldade, mas ao longo das aulas procuram auxiliá-los. O professor Eriberto menciona, na disciplina que leciona os estudantes sem experiência esportiva apresentam dificuldade e os que têm vivência na musculação e modalidades de acadêmica obtêm algumas limitações na compreensão. Abel enfatiza que essa relação não depende apenas dos estudantes, os docentes precisam auxiliar nesse processo. 
As avaliações dos professores descritas no plano de ensino permearam em realizações de: prova, relatórios, trabalhos desenvolvidos em sala, tarefas, participação das aulas práticas, prova prática e avaliação didática. Os docentes distribuíram a nota final em pesos diferentes e realizaram no mínimo duas atividades avaliativa e no máximo quatro. Os professores Abel, Felipe e Larissa, ao final das descrições dos tipos de avaliações, colocaram como será realizado o cálculo da nota final (Figura 23).

Figura 23 - Avaliações as atividades desenvolvidas nas aulas dos jovens doutores

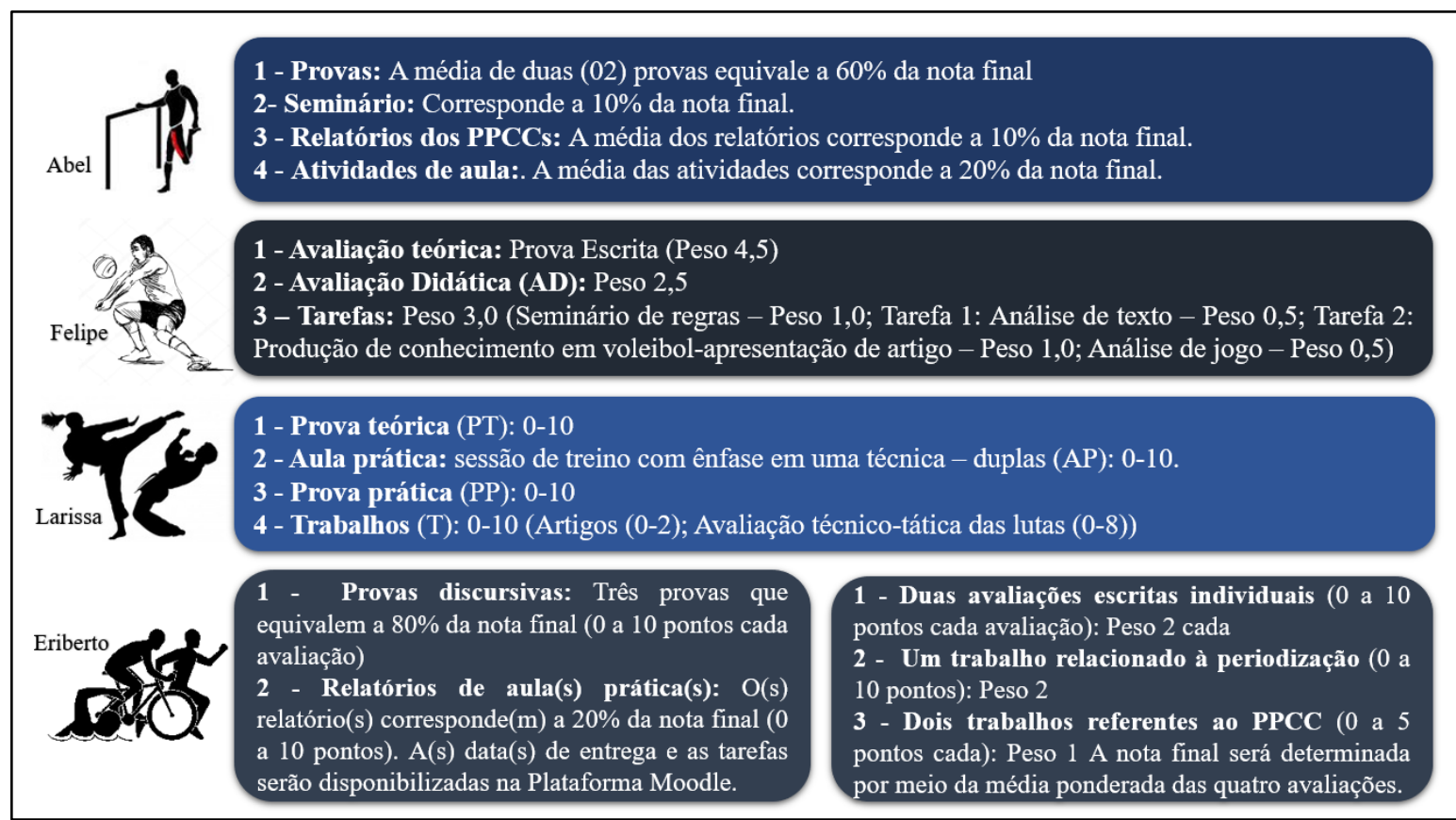

Fonte: Plano de Ensino dos Professores de Educação Física jovens doutores (2018)

Os cronogramas dos professores apresentaram duas formas de organização: os períodos em que seria desenvolvida a unidade do conteúdo programático; as datas específicas das aulas e o conteúdo que seria trabalho em cada uma delas. O importante que essa organização dos conteúdos ao longo do semestre ou ano letivo seja realizada, dessa forma evita o professor tenha problemas no desenvolvimento das aulas, porém a estrutura fica a critério de cada um, desde que tenha data e/ou período e o conteúdo abordado (MASETTO, 2015a).

As bibliografias básicas e complementares são organizadas a partir do material disponibilizado na biblioteca. A primeira bibliografia foi encontrada em todos os planos com no mínimo três (Eriberto) e máximo oito (Larissa), a mais antiga foi de 1975 (Abel) e a mais recente foi em 2015 (Larissa). A segunda foi encontrada nos planos de Abel (n=2), Eriberto $(n=2)$ e Larissa $(n=5)$. Essas bibliografias estiveram centralizadas em livros, a professora Larissa também cita como básica um artigo e na complementar quatro, Eriberto coloca esse 
material em um item separado. A análise do ano de publicação das obras de referência dos professores nos chamou atenção, pois houve prevalência de obras com mais de dez anos de existência (n=26 obras) entre 1975-2008. Conforme apresentado no Gráfico 10, o período de 2006-2010 apresentou 16 obras, entre elas sete ocorreram entre 2006-2008. No período de 2009-2015 identificamos 12 obras, de 38 no total, entre bibliografias básicas e complementares

Gráfico 10 - Bibliografias Básicas e Complementares utilizadas pelos professores de Educação Física jovens doutores

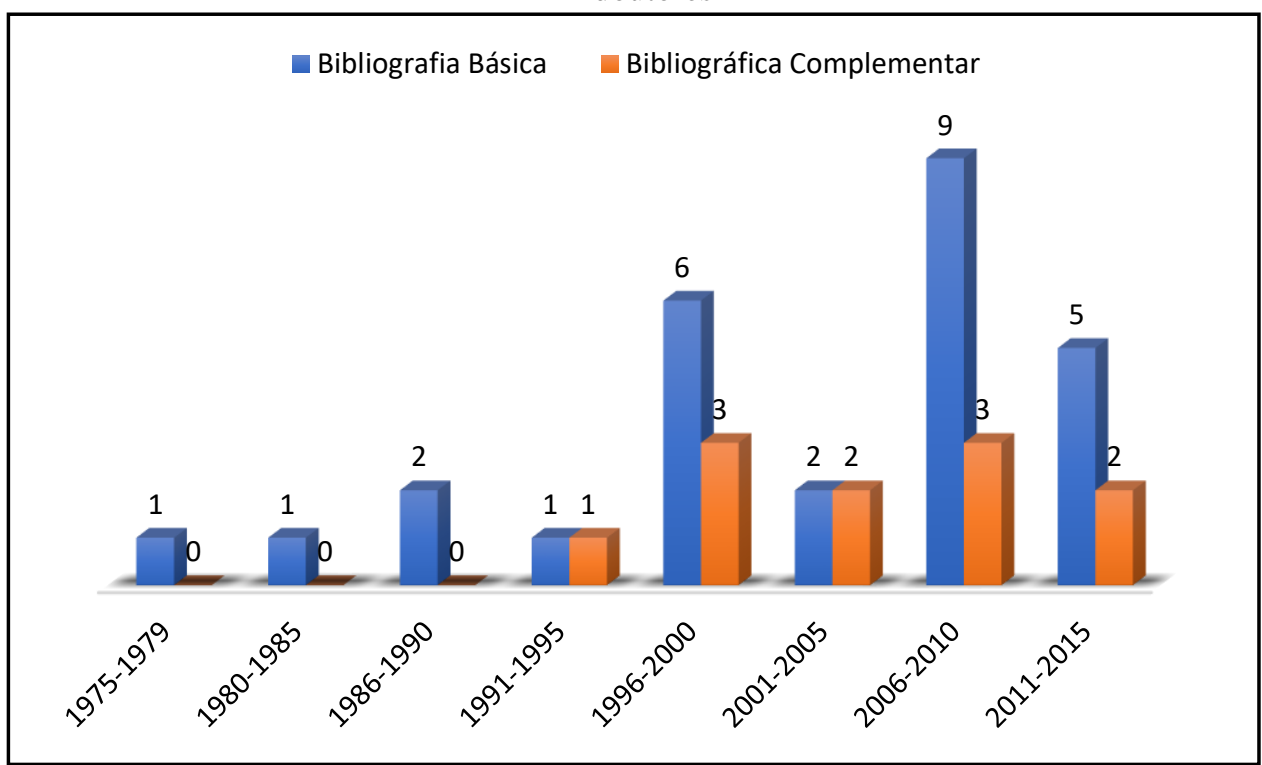

Fonte: Plano de Ensino dos Professores de Educação Física jovens doutores (2018)

Ao longo do nosso trabalho enfatizamos e corroboramos a perspectiva de que ensino, pesquisa e extensão são indissociáveis. Em virtude disso, na entrevista com os professores, procuramos identificar como são trabalhadas a pesquisa e extensão em suas aulas, considerando o fato que atuam em uma universidade norteada por esse tripé. Então verificamos que o docente Felipe envolve os estudantes nas questões científicas a partir de trabalhos em busca de dados, leituras em artigos científicos e discussões de investigações sobre o tema que está abordando em sala.

O professor Abel enfatiza que essa relação do tripé ensino, pesquisa e extensão é muito difícil de realizar, mas todos deveriam fazer, reconhecendo ainda como uma problemática de hoje. O jovem doutor compreende a extensão como algo inovador que precisa de recurso, mas é a última prioridade da universidade. "[...] precisa de recurso, e a gente não tem, e não vamos ter, porque a prioridade é dada para pesquisa e para ensino graduação e pós-graduação - administração e por último a extensão. Então para mim são 
os quatros eixos juntos que tenho feito pior" (ABEL). Não identificamos essa relação na disciplina enquanto observamos as aulas, apenas nas atividades desenvolvidas na residência multiprofissional, em que o docente também atua e nos relatou na entrevista.

A docente Larissa também busca aproximar a pesquisa a partir das discussões em sala, os resultados publicados em artigos científicos possibilitam o estudante a compreender a realidade prática do judô. Relata que tem um projeto de judô e jiu-jitsu na comunidade, tem um bolsista de Educação Física atuando e gosta de aproximar os estudantes da graduação dele, mas encontra dificuldade nessa articulação devido às aulas e o projeto ocorrerem em períodos diferentes do dia.

\begin{abstract}
Então quando eu mostro que diminuiu tanto porcentagem, a intensidade é alta etc. Eu estou mostrando evidências daquilo. Porque eles nunca fizeram uma luta de judô de quatro minutos. E nem vão fazer nas disciplinas, mas eu preciso levar evidências para que eles consigam visualizar isso né? Não simples falar: " a luta de judô é bem intensa né pessoal?" Então trazer estudo corroboram com isso [...] enquanto a parte de extensão, a gente tem um projeto de judô e jiu-jitsu para comunidade [...]. Eu gostaria aproximar mais a graduação desse projeto, mas o meu problema é a questão de horário, não é de manhã, eu não posso exigir que o acadêmico venha em um horário extraclasse, mas seria muito importante se os alunos pudessem ao invés de observar vídeos de lutas, observar lutas em treinamento, pois sempre acontece nos treinos. Isso seria muito interessante se pudessem vivenciar isso, ou fazer arbitragem também (LARISSA).
\end{abstract}

Nessa perspectiva, Eriberto também sente dificuldade de relacionar a pesquisa e a extensão em uma sala com 30 alunos. Tal aproximação ocorre de forma mais individualizada quando os estudantes são bolsistas de seus projetos de extensão sobre natação e musculação e essa mesma realidade ocorre no envolvimento nos laboratórios de pesquisa onde desenvolve seus projetos.

\begin{abstract}
Mas na sala com uma disciplina com 30 alunos, não é tão presente assim, não é tão fácil relacionar, fazer essa relação. Levar esses alunos para realidade da extensão, fato é: tem muitos projetos aqui no nosso centro, muitos projetos de extensão têm... vou chutar um percentual, 50-60\% dos alunos que rodam nas disciplinas comigo semestralmente estão inseridos em algum projeto, principalmente, eles trazem demandas dos projetos relacionados as disciplinas. Eventualmente, quando eles buscam essa relação e quando eles me questionam sobre as situações e possibilidade que eu acabo fazendo. Porque eu não consigo fazer essa relação para sala toda, levar para extensão, nas dinâmicas das duas disciplinas que dou, não consigo pensar nessa relação direta. E é a mesma coisa que acontece com a pesquisa (ERIBERTO).
\end{abstract}

A partir dos relatos desses professores, identificamos a presença de ensino, pesquisa e extensão na instituição onde os jovens doutores atuam e todos eles estão vinculados a esse tripé, mas a relação dentro da sala de aula com os estudantes de graduação é difícil de 
acontecer e quando ocorre é de forma limitada. Ao olharmos esses dados, levantamos os seguintes questionamentos: se os professores de universidades públicas que têm dedicação exclusiva apresentam tal dificuldade, como os docentes de instituições privadas que tem o regime contratual horista conseguem desenvolver essa articulação? Como esses professores jovens doutores realizarão a curricularização da extensão junto aos seus componentes curriculares conforme previsto na Resolução nº 07, de dezembro de 2018 ?

Art. $2^{\circ}$ As Diretrizes para a Extensão na Educação Superior Brasileira regulamentam as atividades acadêmicas de extensão dos cursos de graduação, na forma de componentes curriculares para os cursos, considerando-os em seus aspectos que se vinculam à formação dos estudantes, conforme previstos nos Planos de Desenvolvimento Institucionais (PDIs), e nos Projetos Políticos Institucionais (PPIs) das entidades educacionais, de acordo com o perfil do egresso, estabelecido nos Projetos Pedagógicos dos Cursos (PPCs) e nos demais documentos normativos próprios[...] Art. $4^{\circ}$ As atividades de extensão devem compor, no mínimo, $10 \%$ (dez por cento) do total da carga horária curricular estudantil dos cursos de graduação, as quais deverão fazer parte da matriz curricular dos cursos [...] Art. 19 As instituições de ensino superior terão o prazo de até 3 (três) anos, a contar da data de sua homologação, para a implantação do disposto nestas Diretrizes (BRASIL, 2018b, p. 01-04).

A extensão dentro das instituições de Ensino Superior brasileira apresentará um novo olhar, esse tipo de atividade envolverá todos os estudantes no momento em que realizar articulação com os componentes curriculares. Consideramos que essa proposta contribuirá na aproximação da teoria e da prática dos assuntos discutidos em sala de aula, diminuindo o distanciamento do espaço acadêmico e do profissional. Além disso, na contribuição para a sociedade e para a formação social do estudante.

Consideramos que a sala de aula é um ambiente de aprendizagem, mas também de trabalho profissional, onde há um grupo de pessoas que buscam um objetivo comum de aprendizagem, convivência humana e de relações pedagógicas (MASETTO, 2015a), e para tornar esse espaço Masetto (2015a) relata que precisamos repensar alguns pontos da aula convencional como:

- Espaço físico: mudanças na organização das cadeiras, por exemplo, colocá-las em círculo; deslocamento e mudanças de lugares, possibilitando a movimentação corporal; utilizar outros espaços na instituição para o desenvolvimento das aulas.

- Redefinição dos objetivos da própria aula: tornar-se um espaço de troca de conhecimentos, possibilitando ao professor e aos estudantes se encontrem para debaterem e analisarem o material organizado, estudado, lido, pesquisado e até trazido pelos alunos; elaborar atividades individuais e em grupos para melhor 
compreensão do assunto; que ocorra o planejamento coletivo para o direcionamento do que será realizado, discutido etc.

- Implantação de técnica participativa: repensar e refletir sobre o momento da utilização das aulas expositivas; o aluno deixa de ser passivo e o professor o centro do processo, passando a trabalhar juntos; o uso de diferentes técnicas nas aulas - seminários; debates de oposições; projeto de pesquisa; dramatização etc.

- O processo de avaliação: precisa ser pensado, planejado e realizado de forma integrada à aprendizagem, e modo contínuo, seja nos momentos positivos e negativos. Importante que ocorra o feedback, uma retroalimentação por todos os envolvidos.

Nessa proposta de repensar a aula, Masetto (2015a) corrobora essa percepção de extensão junto aos componentes curriculares, isto é, não precisamos fazer mais em nossas aulas, mas sim fazê-las diferente. Entretanto Anastasiou (2003) faz uma reflexão importante: antes de o professor atuar com uma nova visão sobre o processo de ensino-aprendizagem, ele precisa compreender essa ruptura do tradicional para o novo, a mudança sempre gera desconforto. Em virtude desse contexto, identificamos que já existe um movimento dos professores jovens doutores para que suas aulas se tornem um ambiente de aprendizagem:

- Espaço físico: as aulas ocorreram na sala tradicional, mas houve movimentação do professor na sala, apesar de ficarem "presos" perto do computador para mudança de slides, mas nas atividades em grupos circulavam pela sala. Os estudantes ficavam uma parte da sala em fileira, mas também existiram alterações de lugares e movimentos corporais nas atividades propostas. A professora Larissa realizou a discussão do seminário em formato de círculo.

- Redefinição dos objetivos da própria aula: ocorreram atividades desenvolvidas em sala, organizações de trabalhos de forma coletiva e discussão de materiais lidos, exercícios realizados e materiais construídos.

- Implantação de técnica participativa: a aula expositiva existiu, mas procuravam realizar o diálogo com os alunos, realizaram perguntas e aproximavam da realizada prática instigando a discussão e reflexão. Em uma aula conseguiam aplicar no mínimo duas técnicas diferentes, evidenciadas mais pelos professores Abel e Larissa. 
- O processo de avaliação: os estudantes foram avaliados no mínimo de duas formas por cada professor ao longo do processo de aprendizagem do semestre, mas sua maioria foram três ou quatro formas de avaliação.

O conceito de aula universitária apresenta uma perspectiva que ultrapassa as barreiras da própria sala de aula, ela é importante, sim, mas precisamos olhá-la em outros espaços, como no exemplo da Educação Física: nas escola, nas acadêmica, nos clubes, nos hospitais e postos de saúde, nos locais de lazer, em congressos, seminários, oficinas, dentre outros. Essa perspectiva de realizarmos as aulas em outros ambientes possibilita ao estudante aprender o exercício competente e cidadão da profissão (MASETTO, 2015a).

Reconhecemos que para muitos essa proposta é um desafio, como a construção de um planejamento coletivo com seus pares. Para esses dois desafios, identificamos entre os jovens doutores que, pensar seu plano de ensino e a construção de atividades conjuntas com outros componentes curriculares, é um processo mais difícil do que pensar a aula fora da sala de aula. Identificamos que os professores utilizam outros espaços para atuação conforme identificamos seus planos de ensino e os relatos nas entrevistas como: laboratório, clubes, escolas, quadra, tatame, conversa com especialistas, dentre outras atividades. Quanto o planejamento coletivo houve limitações: existiu o diálogo para articulação dos conteúdos e encerrou ali; e quando ocorreu atividade em conjunto, como menciona Larissa e Felipe, não foram propostas deles, e sim de outro professor. A docente relata que realizava um festival de judô e articulava com a organização de eventos, mas pelo comportamento inadequado dos estudantes decidiu encerrá-lo.

Os professores universitários iniciantes apresentam dificuldades no contexto de sala de aula, mas também as questões administrativas e burocráticas. A primeira está atrelada a seleção de conteúdo, avaliação, relacionamento com os alunos e trabalhar com diferentes perfis de estudantes. Enquanto a segunda está associada a infraestrutura deficitária; estrutura acadêmica, como preenchimento de documentos; forma de gestão; e diversidade de grande número de aulas (ZANCHET et al., 2014).

Masetto (2015b) nos ajuda a pensar para que essa proposta se desenvolva com menos dificuldades e mais eficácia: a) elaboração por equipes de professores do mesmo semestre e com a mesma turma; b) analisar os objetivos educacionais iguais, semelhantes e/ou integrados, assim auxiliar na relação estabelecida. A partir disso os docentes poderão: 
diferentes áreas, mas que se complementam; estudar casos à luz de conceitos de duas ou mais disciplinas; realizar debates entre professores com seus alunos; solicitar trabalhos e /ou monografias produzidas com apoio das diferentes disciplinas [...] (MASETTO, 2015b, p. 89-90)

Ações como essas contribuem para a prática pedagógica do professor, deixando de reproduzir os conteúdos da forma como aprendeu, adequando a realidade na qual se encontra; proporciona a construção de uma nova proposta em sua prática; (re)constrói seu conhecimento e identidade a partir da relação com seus pares, proporciona uma relação de pertencimento ao grupo de professores com quem trabalham, pois buscam os mesmo objetivos.

A partir dos estudos analisados para construção do estado da arte sobre a prática pedagógica de professores universitários, identificamos algumas semelhanças e distanciamentos na organização e desenvolvimento com a prática dos jovens doutores. Importante salientar que o diálogo entre seus pares na instituição é necessário para sua prática pedagógica, mas a relação com profissionais que atuam nas diferentes áreas da Educação Física também é um fator relevante. O professor universitário com dedicação exclusiva acaba se voltando mais para a pesquisa e se distanciando da prática profissional em si e, com o passar do tempo, muitas situações vão mudando, precisa-se de uma rede de relações que contribuam para que ocorra essa "atualização".

A professora Larissa, ao chamar o mestre especialista em Defesa Pessoal, possibilita essa proximidade, também como participação recente em congressos, como o professor Abel. Conforme os docentes universitários, entrevistados por Fernandez (2007), da área de administração e empreendedorismo alegam, precisam do diálogo com o docente que trabalha consigo na IES, mas também com os empresários e funcionários das empresas para os auxiliarem numa boa relação entre a teoria e a prática.

A proximidade existente com os pares contribui para o desenvolvimento da prática pedagógica do professor universitário, além de aproximá-los enquanto profissionais e pessoas. Essa relação auxilia para um ambiente colaborativo entre os professores, consequentemente, facilita o surgimento de atividades entre componentes curriculares e propostas inovadoras (RAMOS, 2014). Esse autor ainda revela que as ações inovadoras proporcionaram aos docentes uma perspectiva diferente do processo avaliativo, o qual era considerado um dos elementos mais complexos de sua prática.

Na percepção de professores enfermeiros universitários, as práticas inovadoras são difíceis de aplicá-las devido à ausência de infraestrutura, conteúdo mínimo das disciplinas e 
capacitação docente nas tecnologias de informação e comunicação, mas reconhecem que há necessidade de mudanças de estratégias de ensino, principalmente porque o estudante precisa ser mais participativo e precisa explorar outros espaços além da sala de aula (GUARESCHI, 2015). Os professores universitários de Educação Física de universidades públicas apontam que 38,03 (n=89) sempre e 49,15\% (n=115) quase sempre conhecem e utilizam recursos diversificados e inovadores no processo de ensino-aprendizagem.

O estudo de Matias (2013) com professores universitários de odontologia aponta que as aulas são tradicionais, basicamente teóricas, e as exposições dos conteúdos são via slides. Entretanto os estudantes reconhecem os benefícios das metodologias ativas, mas para formação de cirurgiões dentistas preferem aulas de cunho tradicional. Enfatizam também, para que as metodologias ativas sejam aplicadas, é preciso a capacitação dos professores e o projeto político pedagógico do curso precisa se articular com a prática pedagógica do professor. Sobre essa questão de metodologias ativas, professor Abel revela ter conhecimento, pois trabalha na residência multiprofissional e o questionamos sobre a aplicabilidade no curso de Educação Física.

\begin{abstract}
Então, hoje eu consigo fazer em algumas aulas e algumas coisas, não digo que são metodologias ativas porque para trabalhar com metodologia ativa não pode ser uma disciplina, tem que ter um curso que trabalhe com essa lógica. $O$ aluno precisa entender e aceitar também que ele não será só espectador naquela disciplina que ele também irá produzir. E produzir implica ele ter tempo disponível e estar disposto a fazer isso. Muitas vezes eu observo os alunos com proponho alguma metodologia que é mais ativa que eles têm que trabalhar, eles gostam muito, porque é um momento que eles param para estudar que eles têm que discutir entre o grupo $(A B E L)$.
\end{abstract}

Identificamos em outros estudos que os professores universitários também utilizam: trabalho em grupo e individual, dinâmicas, usufruem das tecnologias de comunicação e informação, apoio de recursos audiovisuais, leituras, dentre outros (FERNANDEZ, 2007; MOLETTA, 2013; GUARESCHI, 2015). O estudo de Nunes (2016) com professores universitários de Educação Física que atuam em instituições públicas com formação da graduação ao doutorado e com diferentes tempos de carreira docente revela que: 51,28 \% $(n=120)$ dos professores sempre utilizam e conhecem diferentes instrumentos de avaliação; $14,96 \%(n=35)$ quase sempre; $14,10 \%(n=33)$ raramente; $2,99 \%$ quase nunca $(n=7)$; e 16,67\% (n=36) não conhecem e não utilizam. Esse estudo não aponta quais são os instrumentos.

A prática pedagógica dos professores universitários no curso de administração e empreendedorismo (FERNANDEZ, 2007) e de Educação Física Licenciatura e Bacharelado 
(MOLETTA, 2013) apresentam preocupação com a proximidade da realidade profissional. Os jovens doutores apresentam tal preocupação em realizar atividades práticas, trazendo situações reais, construção de treinamento dentre outros, isto é, utilizam-se de estratégias e instrumentos para que isso aconteça.

Os desafios enfrentados pela docência universitária, bem como para a construção da sua prática pedagógica foram superados pelos jovens doutores investigados, como por exemplo: a superação de uma aula apenas expositiva, já se utilizam de aulas expositivodialogadas. Usufruem de diferentes estratégias de ensino e de recursos materiais, compreendem a avaliação como um todo a partir do uso de instrumentos e realizada em diferentes períodos. Ainda carecem de um trabalho coletivo com outros professores e aproximar a extensão universitária de suas práticas, considerando que a pesquisa timidamente encontra-se presente. "O grande desafio do [professor] iniciante é perceber o caráter de totalidade exigido para o exercício de uma docência que rompa com essa fragmentação" (ZANCHET et al., 2014, p. 190). Além disso, esse contexto possibilita compreender também a construção da identidade profissional do docente, que ainda há de enfrentar algumas rupturas de concepções, e serem desafiados a realizarem práticas pedagógicas diferentes para alcançar o que se espera do professor universitário.

\subsection{CONTRIBUIÇÕES DA SOCIALIZAÇÃO PRIMÁRIA E SECUNDÁRIA PARA AS PRÁTICAS PEDAGÓGICAS}

Ao longo da fundamentação teórica compreendemos que o docente do Ensino Superior a partir da dimensão profissional, pessoal e laboral (ZABALZA, 2004; ISAIA, 2006). E que as atribuições da docência exigem do professor o conhecimento do conteúdo específico do seu componente curricular, mas também o conhecimento didático-pedagógico os quais contemplem: identificar e solucionar problemas, selecionar assuntos a serem abordados, verificar quais as melhores estratégias metodológicas para a turma, trazer bem claros os objetivos que desejam alcançar, comunicar-se com os estudantes individualmente, bem como em grupo, proporcionar um espaço de aprendizagem que o aluno se estimule para o desenvolvimento nesse processo (ZABALZA, 2004; PEREIRA; MEDEIROS, 2011; THERRIEN; DIAS; LEITINHO, 2016).

Conforme a literatura vem abordando a formação pedagógica para atuar no Ensino Superior ainda está restrita na trajetória acadêmica dos professores centralizada apenas nas disciplinas e estágio de docência na pós-graduação (PACHANE, 2006; ALMEIDA, 2012; 
MASETTO, 2015a). O conhecimento sobre propostas curriculares e processos de ensinoaprendizagem é escasso, por muitos docentes. Nosso estudo revelou: os jovens doutores apresentam uma formação de cunho pedagógico, mas referente ao ensino na Educação Superior ficou restrita em uma ou duas disciplinas realizadas no mestrado e/ou doutorado e nos estágios de docência. Também não identificamos cursos ou formações complementares que contribuísse nesse quesito, muito menos, relatos sobre oportunidades propiciadas pela instituição que lecionam. Em virtude, dessa realidade, decidimos organizar as contribuições proporcionadas a partir da socialização primária e secundária (Figura 24).

Figura 24 - As contribuições das socializações primária e secundária para as práticas pedagógicas

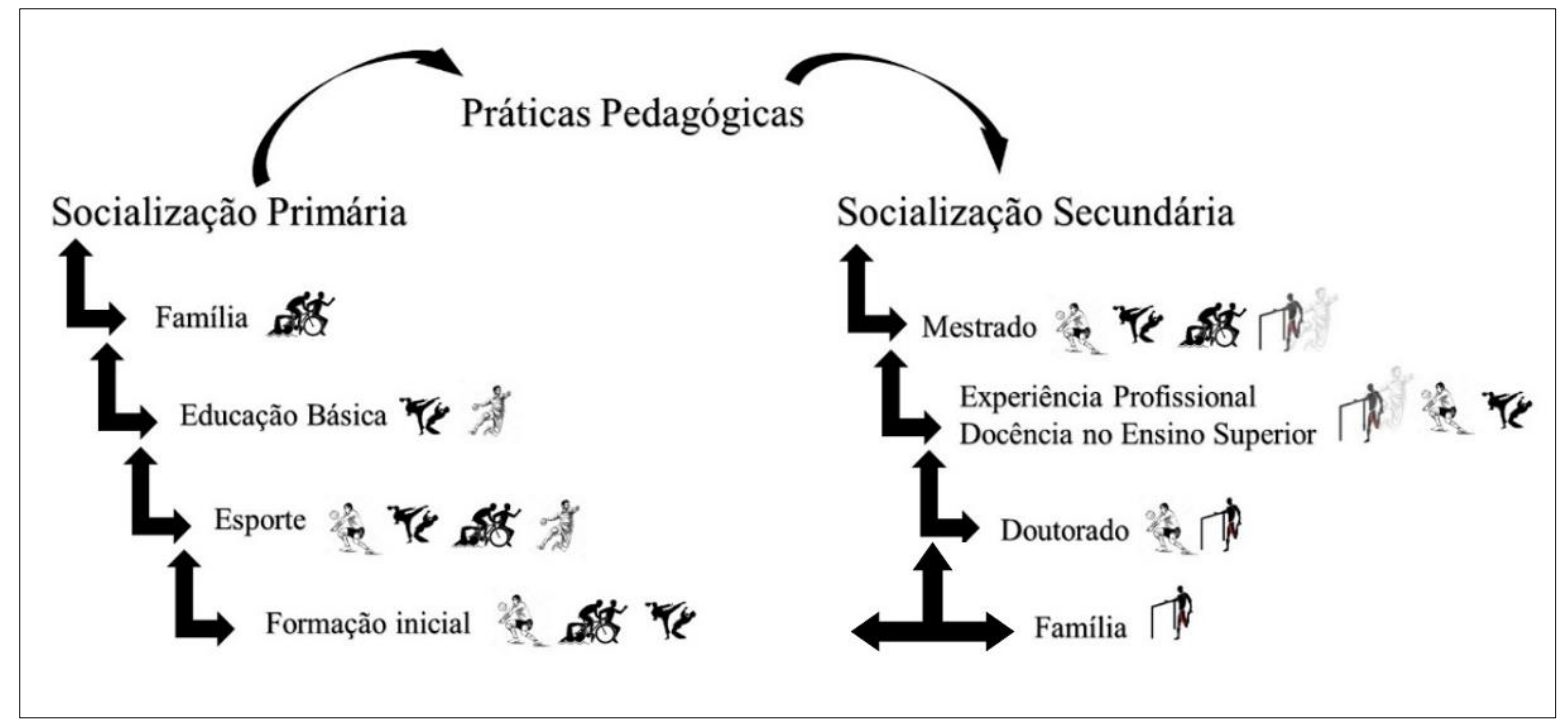

Fonte: Entrevistas estruturada e sobre a história de vida realizadas com os Professores de Educação Física jovens doutores (2018)

As contribuições advindas da socialização primária foram organizadas a partir dos contextos familiar, da Educação Básica, do Esporte e da Formação Inicial, sendo os três primeiros os quais também nortearam a escolha profissional dos jovens doutores. Entretanto, é importante salientar que essas categorias não foram atribuídas a todos os docentes, pois cada um apresentou especificidades em sua trajetória pessoal e profissional.

Os docentes Eriberto e Abel apresentaram contribuições familiares em períodos diferentes de sua vida. O primeiro professor ocorreu ao longo da socialização primária, isto é, ocorreu na infância e adolescência, antes de ingressar na faculdade, a partir das vivências que obteve no ambiente de trabalho onde sua mãe atuava - universidade pública contribuíram para escolha profissional, mas também para sua prática pedagógica na questão relação professor-aluno. 
Eu acredito que principalmente a relação com os alunos, eu sempre ouvia os alunos falando bem dela. Que ela tinha uma boa relação, no sentido professor e aluno. De se preocupar com os alunos e as demandas que os alunos vêm trazendo da universidade. Acredito que seja isso, porque o que eu vivi com a minha mãe, foram as falas delas, são essas as lembranças que eu tenho (ERIBERTO).

Enquanto Abel a vivência familiar, quanto as relações com seus pais e irmãos, não houve contribuições, mas a experiência de tornar-se pai possibilitou um repensar na sua carreira enquanto docente e na sua prática pedagógica. E essa ruptura ocorreu na socialização secundária, certamente também contribuindo na sua (re)construção identitária social e profissional. Na entrevista revela que com o nascimento de sua filha mudou sua organização, pois antes levava trabalhos para serem desenvolvidos em casa, a partir desse momento precisou realizar algumas modificações e selecionando algumas atribuições dentro da área acadêmica. Destacou um ponto interessante com essa nova atitude: percebeu que seus pares compreendem melhor alguma negação de tarefa e/ou qualquer outra demanda quando relaciona a questão familiar, assim compreendemos que a identidade virtual de professorespais é diferente daqueles que não possuem filhos:

A questão de quando nasceu minha filha eu comecei a identificar que fazia algumas coisas que não eram tão importantes para o que eu quero na minha formação. Tem algumas coisas que eu poderia deixar de fazer que não iria deixar de ser menos ou mais importante na área acadêmica, selecionar mais as coisas. Isso me ajudou. Antes eu tinha receio de fazer, hoje consigo fazer mais tranquilo, até porque eu tenho uma desculpa né? Socialmente, não posso porque estou com a minha família etc. Parece que as pessoas aceitam mais, eu tenho essa impressão. Acho que foi mais nesse sentido na relação com meu trabalho [...] (ABEL)

Quanto a questão da contribuição em sua prática pedagógica em si, Abel, aponta que pôde repensar alguns pontos discutidos em sala, até mesmo os exemplos passados aos estudantes depois que teve sua filha. E isso esteve mais impacto, pois o docente leciona a disciplina de crescimento e desenvolvimento humano, assim identificando que os livros e artigos não contam tudo que acontece na vida da criança, por exemplo. A vivência prática do crescimento e desenvolvimento da sua filha, possibilita o docente refletir sobre as formas que os conteúdos são abordados.

Tem muitas coisas que eu consigo ver na prática, até eu levo os exemplos da minha filha para a aula. A curva de crescimento, até porque é real, eu consigo explicar o que aconteceu os reflexos e isso é interessante. Tem coisas que não estão escritas nos livros, isso todos sabem. Mas dificilmente falam. Por exemplo: processo de adaptação escolar, a gente fala: " a criança vai crescer assim de Zero a Dois anos", mas entre esse período acontece várias coisas com ela que não está escrito nos livros e nos artigos científicos, que impacta de forma significativa de como vai trabalhar com essas crianças. Essa experiência de inserção escola, só quem viveu isso sabe como isso altera a alimentação, sono, comportamento etc. tira totalmente 
da curva de crescimento normal de uma criança. Tem crianças que rapidamente de adaptam e tem crianças que levam meses para se adaptação. E o estresse para o pai e para família é grande. Só que isso não tinha prestado atenção, percebi que tinha algo padrão que acontecendo. Às vezes, nós damos um diagnóstico de crescimento que nem sempre é tão alarmante, então comecei a trabalhar na disciplina que eu vivencio (ABEL).

O contexto esportivo foi marcante na socialização primária de todos os jovens docentes sendo antes da inserção na graduação e após dela, desta forma trazem consigo as experiências com o esporte para sua vida social e profissional. Identificamos nas narrativas dos professores essas contribuições, mas foram reafirmadas ao longo das aulas observadas, pois conseguiram aproximar o conteúdo abordado com exemplos na área esportiva até mesmo de suas vivências na modalidade.

\begin{abstract}
A vivência no ambiente esportivo me fez compreender como funciona o esporte, não o esporte apenas de rendimento, mas os diferentes níveis de esporte: de participação, de educação... até mesmo por que eu participei de todos eles né? Então, quando eu dou aula hoje eu procuro pensar: "a onde esse aluno está pensando em trabalhar? Está pensando em trabalhar no esporte de rendimento?". Então que e quais conceitos que minha disciplina tende a trabalhar e consiga entrar e compreender um pouco nessa parte de rendimento ou não ele quer trabalho no esporte social... Ou seja, são nicho diferentes que tem que se formar para todos, tem que ter noção de todos, e isso o esporte me deu esse entendimento [...] ]eu migrei da área de esporte para área da saúde, depois da graduação. $\mathrm{Na}$ pós-graduação [...] o esporte me levou entender a importância do esporte em outros contextos [...] então nas minhas aulas eu procuro trabalhar esses dois lados dessas facetas do esporte, da atividade física, das práticas corporais independe do nome que dá. Essa experiência o esporte me deu, quem sabe isso eu poderia interagir com o aluno sem essas vivências e experiências de estar naqueles momentos (ABEL).
\end{abstract}

O docente Eriberto nos aponta que a experiência esportiva o proporcionou olhar e discutir os conteúdos abordados em sala para além dos livros, ainda mais, identificou o funcionamento e alterações fisiológicas do corpo humano a partir da prática de exercício físico. "Quando você vivência consegue explicar de uma forma diferente, você tem algo a mais para dar argumentos, nesse ponto de vista didático conseguir se armar mais e ter mais fundamentação por ter experimentado e vivenciado diferentes intensidades de diferentes esportes" (ERIBERTO). Além dessa perspectiva didático-pedagógica fez o apontamento sobre algumas questões subjetivas que o esporte proporcionou a ele enquanto professor e profissional de Educação Física, como lealdade e respeito ao próximo. Além disso, menciona que continua praticando os esportes individuais e consumindo os esportes coletivos a fim de discutir as questões de treinamento em diferentes modalidades com os estudantes em sua disciplina. 
[...] quando falamos em lealdade, respeito ao próximo eles me ajudaram muito. Talvez essa é uma das características minhas psicológicas e emocionais [...] então eu diria que eu sou um consumidor dos esportes coletivos que me agregam à docência, principalmente na disciplina de treinamento, essa possibilidade de conversar com os alunos de outras modalidades e que tem interesse em outra modalidades, assim até que consiga integrar o conhecimento que eu tenho do treinamento com aquela modalidade (ABEL).

O esporte na socialização primária de Felipe e Larissa apareceu em momentos diferentes, mas permanecem até hoje levando à docência específica da modalidade que praticavam. O primeiro professor vivenciou o voleibol ao longo da sua infância e adolescência e a segunda docente o judô começou fazer parte da sua vida ao longo da graduação. Os dois professores ao longo da prática profissional conseguem discutir com propriedade o assunto, Larissa em alguns momentos se faz como exemplo quando da prática esportiva tardia.

Em virtude disso, aguçou nossa curiosidade e realizamos algumas perguntas específicas identificadas ao longo das aulas observadas. A professora Larissa afirma que traz o exemplo da sua vivência tardia no judô a fim de os estudantes compreendam que realmente acontece, não fica da abstração

[...] às vezes você fala citando autores e acaba com que os alunos pensam que nunca irá acontecer. E quando você dar um exemplo próximo de você, por simples que aconteça, mostra que isso é possível acontecer e faz com que os alunos pensem diferente. E se perguntem: será posso aprender um esporte na vida adulto? ou melhor ainda será, será que eu posso estimular outras pessoas praticarem o esporte na vida adulta? Considerando que essa é a minha fundação enquanto professora. Eu acho que talvez me colocando como exemplo os alunos consigam ver que isso não é algo tão longe e que isso é possível. E tem um milhão de exemplos, é naquele momento eu me coloco como exemplo porque eu passei por aquele processo. Eu acho que ajuda, não sei! (LARISSA)

O professor Felipe faz uma consideração importante sobre a necessidade do professor que atua na área esportiva vivenciar a prática, mas também continuar acompanhando os acontecimentos, isto é, se atualizando do que vem ocorrendo nesse contexto. Além disso, hoje consegue ser crítico sobre a prática que ele realizava também favorecendo dar exemplos positivos e negativos, bem como realizar apontamentos de experiências de sucesso e/ou não.

[...] se você não tem uma formação, você não tem um olhar mais crítico sobre aquilo que está fazendo. A partir do momento que você tem formação obviamente você remeter fatos ocorridos e experiências, com certeza ajudam. [...] consigo fazer uma reflexão daquela prática que eu tive também. Quando você recebeu um treinamento uma aula você não jogava, você fazia. "Tal legal!" Mas não faz uma análise crítica sobre a metodologia do professor. Mas então a partir que você tem 
formação você faz e utiliza para dar exemplo positivos e negativos, se funcionava se não funcionada etc. E na área esportiva também se você não tem experiência fica é muito complicado em falar sobre isso. Tem um comentário, se você se afastar um pouco do cenário fica falando uma coisa que não está acompanhando que na prática está acontecendo. E as coisas vão mudando, e você fica falando coisa que está passada. O convívio da experiência prática que eu tive foi muito importante (FELIPE).

O contexto escolar apareceu na proximidade com a Educação Física e o esporte na narrativa dos jovens doutores, mas quanto ao reconhecimento de suas contribuições para sua prática docente foram evidentes para o professor Abel e Larissa. O primeiro aponta que chamava atenção a organização de sua escola, pois a mesma sala era composta por alunos de primeira e quarta série com apenas uma professora, e se questionava como conseguia lecionar para crianças de diferentes períodos escolar. E a partir dessa vivência obtém a concepção que não podemos pensar o ensino dentro de uma caixa, isto é, os estudantes precisam pensar além da sua área, é importante que transitem em outras áreas do conhecimento e o que está sendo discutido sobre os assuntos em comuns.

\begin{abstract}
Eu comentei no histórico de vida. Eu me lembro muito das aulas no a espaço escolar, que eu vivenciei muito na primeira série até a quarta série e que eu tinha apenas uma professora, que atendia de primeira à quarta série, mas a professora conseguia, mesmo tendo diferentes níveis de ensino dar aula para todos no mesmo local. Isso me chamava muita atenção. Então fui compreender um pouco melhor o sistema. Eu tento aplicar e eu trouxe de lá, e não sistematizar as coisas muito em caixa. Por exemplo, eu estou trabalho com uma turma do primeiro ano da graduação [...], mas que eles tenham noção no universo que eles estão, muitas vezes, o aluno não entendi. Então tem questões pedagógicas que tento trabalhar bastante, na disciplina que eu ministro que é crescimento e desenvolvimento [...], mas com o contexto que eles estão dentro da universidade. Eles têm que entender o que acontece dentro da medicina, o que os pediatras estão trabalhando, tipo inter-relacionar isso quem eles vão atender. São crianças que estão indo para pediatras, adolescentes que estão em fase de maturação ou psicólogos o que está acontecendo... Então isso eu trouxe de lá de trabalhar junto com outras profissões que desde de lá me chamava muito atenção, pois a professor de lá ao mesmo tempo ela era educadora, ela cuidava da merenda, ela cuidava da chamada, ela era diretora da escola, era um pouco diferente, mas era algo muito interessante (ABEL).
\end{abstract}

A professora Larissa relata que ser aluna de escola pública na Educação Básica, contribui para seus exemplos quando leciona no curso de Licenciatura. “[...] essa história de estudar em escola pública [...] tenho muito presente. Eu tenho essas lembranças, das dificuldades que tinham, da falta de dinheiro. E aqui continua [...] e me ajuda a discutir com os alunos, mas pode me auxiliar de uma forma mais direta do que indireta” (LARISSA).

$\mathrm{Na}$ graduação todos os jovens doutores apontaram que houve contribuição para sua prática pedagógica atual, mas cada um com sua especificidade. Vejamos Abel e Felipe 
realizaram a graduação na mesma universidade, ou seja, apresentaram o mesmo contexto institucional na socialização primária quanto a formação inicial, mas as marcadas na sua formação pedagógica para atuar no Ensino Superior foram distintas: o primeiro menciona que as vivências em grupos de pesquisa, envolvimento em projetos de pesquisa e extensão, participações em eventos científicos e as proximidades com o contexto da pós-graduação auxiliam nas suas atribuições como docente na universidade em si. E o segundo elucida que aprendeu que a aula atrativa aos estudantes nem sempre proporciona subsídios necessários para formação profissional, além disso, aponta que estágio obrigatório realizado na Educação Básica contribuiu para sua prática para as discussões sobre iniciação esportiva.

[...] o pessoal falava o tempo todo em publicação científica, em buscar artigos, a importância de participar dos eventos científicos. Então esse convívio, mesmo que muitas vezes não entendesse muitas coisas, não participasse a fundo, mas eu vivenciava e estava ajudando, mas não importava, porque depois ajudou muito na pós-graduação [...] além disso, me permitiu vivenciar de diferentes reuniões, grupos, quando estava no laboratório. A dinâmica de responsabilidade, de ter tarefas para comprimir, ter pessoas que estão esperando que você cumpra aquela tarefa, isso eu aprendi nos grupos, gestão de grupo. E isso com o tempo me ajuda na minha carreira profissional, porque, querendo ou não, quando eu virei professor eu tive que fazer tudo isso. De outra forma, fazendo a gestão disso, mas tem que estar na pesquisa, ensino e extensão e como faz isso. Se você não tem a questão de gerência muito boa, acaba te sobrecarregando muito (ABEL).

O currículo obrigatório na educação básica... Eu gostei bastante da experiência que eu tive, apesar de não atuar mais na área. A experiência, eu tive um semestre como estagiário, mas ministrava boa parte das aulas, na Educação Básica, terceiro ano... A gente trabalhava basicamente com estimulação motora, algo do gênero [...] Foi bastante importante, hoje temos propriedade para acertar algumas coisas, por exemplo: quando vamos trabalhar a iniciação esportiva e encontra uma situação com crianças, quais são os desafios e diversidades, quais são as respostas lá dentro [...] eu vejo o que eu vivenciei no meu estágio da graduação foi importante paras aulas que dou hoje para falar melhor sobre os assuntos, você tem vivências, pode falar com mais propriedades e enxergar coisas diferentes. Enfim...foi bom e importante [...] (FELIPE)

aula dele era tão atrativa para quem estava fazendo, que ninguém questionava, pois ele se preocupada com o aprendizado do aluno. Mas isso não é o suficiente, pois ele não discutia muito o método de utilizar [...], mas isso também foi um aprendizado, a aula tem que ser atrativa, mas de alguma forma faltava um pouco mais discussão e reflexão em cima daquilo (FELIPE).

As contribuições para professora Larissa estiveram relacionadas às ações de dois docentes que ela conviveu na graduação a partir das estratégias de ensino que carecia os alunos estudarem e se aprofundarem do conteúdo abordado. Além do próprio judô, que mencionamos na categoria esporte, e as experiências no projeto de extensão também foram marcantes para sua formação docente. 
Eu tive algumas disciplinas que me auxiliam até hoje. Uma delas foi com a Professora [nome] de Adaptações orgânicas, foi muito bom! a Professora agregava muito, como fazer nós trabalharmos em grupo. Obrigava nós estudarmos, como todo aluno (risadas), nós estudávamos, mas já sabe... Foi muito importante ter essa disciplina. A disciplina do Professor [nome] [...] trabalhava com a formação profissional a base dos treinadores [...] me ajudou se realmente queria dar aula. Outro professor que me ajudou muito foi o professor [nome]. Fui monitora do projeto de extensão dele por vários anos [...], mas foi um professor que me acolheu no início e fizemos várias coisas juntos também (LARISSA).

O professor Eriberto aponta que na fase da graduação, bem como no mestrado, a riqueza dessas formações foi vivenciar a iniciação científica e a prática como atleta ao mesmo tempo, pois proporcionaram a associação da teoria e da prática. Essas duas experiências de forma simultâneas o auxiliaram na compreensão da fisiologia nesses dois contextos (teóricoprático). Outro de aporte ao longo do mestrado foi a convivência com estudantes de graduação e orientações com TCC e a disciplina de Didática no Ensino Superior e de Fisiologia Experimental.

[...] foi na graduação que eu comecei a ter essa relação com o laboratório e isso foi durando no meu mestrado. Então foram cinco anos contínuo que eu tive essa relação direta de praticar e pesquisar, ao mesmo tempo eu praticava e fazia pesquisa sobre aquilo que eu praticava. Acho que esse é a maior riqueza que eu trago hoje, desde sempre, pois estou falando antes dos anos 2000 foi... Então, mais de 20 anos atrás praticamente que eu iniciei esse processo em relação - com o que eu praticava e fazia pesquisa daquilo que eu estava praticando. De lá para cá eu continuo praticando, competindo e pesquisando também (ERIBERTO).

As contribuições da socialização secundária para as práticas pedagógicas dos docentes foram encontradas na pós-graduação stricto sensu (mestrado e doutorado) e nas experiências enquanto professores no Ensino Superior antes de ingressar na UPC. O curso de mestrado os professores Abel, Felipe e Larissa realizaram na mesma instituição - UPC mas suas contribuições também ocorreram de formas diferenciadas. Os dois primeiros professores para as relacionaram com as práticas pedagógicas de seus professores e a outra docente direciona as questões das disciplinas vivenciadas e o estágio de docência. Destacamos dois pontos interessantes: $1^{\circ}$ ) O professor Abel aborda sobre as estratégias de ensino utilizadas por sua professora supervisora do mestrado, as quais foram identificamos ao longo de suas aulas observadas nessa pesquisa. Além disso, essa mesma professora contribuiu para prática da professora Larissa na graduação; $2^{\circ}$ ) Felipe reconhece que os contatos realizados com treinadores de atletismo devido sua pesquisa foi de grande valia.

quando eu vim para cá eu fui supervisionado pela professora, que não está mais aqui, mas fez a diferença no meu mestrado em termos didáticos e aprendizagem, que foi a Professora [nome]. [...] aprendi várias coisas como dar aula, de como 
tratar o alunos, eu aprendi muito com ela, coisas que era muito importante e interessante que ela fazia e que eu tento fazer como: retomar aula do ponto da aula anterior, fazer uma revisão, e fazer com que os alunos participantes dessa revisão, ver o que eles lembram daquilo, [...] a valorização do ensino básico para formação básica mesmo. E não a especialização na formação básica. [...] e isso me chamava muita atenção quando ela trabalhava e como isso se desenvolvia (ABEL).

Tive contato com treinadores de atletismo, dessa época do mestrado a que eu tirei como principal aprendizado foi: conhecimentos novos, conteúdos que não tinha visto, equipamentos novos, puxamos a frente na instalação de equipamento, mexer em equipamento, enfim foi bem interessante (FELIPE).

No doutorado Felipe refere-se sobre uma disciplina realizada nesse período que contribuiu para sua reflexão das metodologias e estratégias utilizadas ao longo de suas aulas, conforme apontamos anteriormente no capítulo 5. Enquanto Abel menciona os conhecimentos e aproximações com as metodologias ativas contribuíram de forma positiva para sua prática, e a sua vivência em Portugal possibilitou identificar que os professores brasileiros são muito paternalistas, pois lá o estudante precisa ir em busca do que almeja, contrário da nossa realidade.

As experiências enquanto docente do Ensino Superior contribuíram para as práticas de Larissa quanto a solucionar problemas que aparecem no cotidiano do professor como: falta de material e dividir os espaços e materiais. Para professor colaborou para proximidade com a prática em si e a questão ser mais flexível em suas percepções.

\footnotetext{
A experiência docente na [nome da instituição] foi muito importante para agora eu conseguir enriquecer melhor a minha prática. Então a gente acaba sempre se permitindo crescer e modificar quando precisar. Como diz o professor Kunz: "hoje eu posso dizer que é certo, amanhã eu posso dizer que está errado”. [...] A gente percebe que as vezes se enraíza muito numa coisa, naquele momento que você está vendo parece é bom, depois não é mais. Nessa questão da prática docente precisamos ser bastante flexíveis para podermos sobreviver (FELIPE).
}

E para Abel foi a possibilidade de lecionar em diferentes disciplinas que o possibilitou estudar e aprofundar diferentes conhecimentos, os quais ele consegue articulálos em suas aulas. Além disso, releva que a estratégia que ele utiliza de construção de uma resenha no final da aula, foi uma adaptação de uma atividade que o professor de basquetebol que trabalhava com ele fazia, a qual achou interessante e começou usá-la conforme as adequações necessárias para o seu componente curricular. "Essa questão de fazer a resenha no final da aula ... eu tinha um professor fazia na [instituição que lecionada], era um professor de basquetebol das aulas práticas. No final da aula ele pedia para que todos os alunos desenharem todos os exercícios que tinha feito em quadra [...]” (ABEL). 
A partir dessa análise compreendemos que os componentes curriculares que realizaram ao longo de sua formação acadêmica auxiliam para sua prática docente atual, mas ficou evidente que houve outras contribuições atribuídas a partir da socialização primária e secundária. Tais quais também marcam a identidade docente dos jovens doutores.

Ao longo das narrativas dos professores não foi mencionado que a própria instituição UPC contribuiu para sua prática pedagógica depois que se tornaram docentes, nem mesmo nas instituições que lecionaram. A vivência de metodologias ativas apontada por Abel, foi o mais próximo de uma formação pedagógica que contribuiria para sua prática.

As IES ainda carecem de uma formação continuada de qualidade aos docentes, há poucas que apresentam ações de reflexão teórica mais concisa sobre as questões pedagógicas, ainda predomina-se uma perspectiva racionalista entre as universidades. A autora Cunha (2012; 2014) organiza essas propostas de formação em três modelos em ordem descrente de centralização.

Quadro 13 - Modelos, características e pressupostos da formação docente conforme Cunha (2012; 2014).

\begin{tabular}{|c|c|c|c|c|}
\hline MODELO & $\begin{array}{c}\text { PROCESSO E } \\
\text { CARACTERÍSTICAS }\end{array}$ & $\begin{array}{l}\text { COMPREENSÃO } \\
\text { DA FORMAÇÃO }\end{array}$ & $\begin{array}{l}\text { ESTRATÉGIAS } \\
\text { DE FORMAÇÃO }\end{array}$ & $\begin{array}{l}\text { FORMAS DE } \\
\text { AVALIAÇÃO }\end{array}$ \\
\hline Centralizado & $\begin{array}{l}\text { Oferecida a todos os } \\
\text { docentes; } \\
\text { Decisões pelo órgão } \\
\text { gestor; } \\
\text { Eventos episódicos; } \\
\text { Resultados não } \\
\text { controláveis; } \\
\text { Descrição quantidade } \\
\text { dos participantes }\end{array}$ & $\begin{array}{c}\text { A formação é um } \\
\text { processo } \\
\text { individual. } \\
\text { Cada docente é } \\
\text { capaz de processar } \\
\text { as informações e } \\
\text { conhecimentos e } \\
\text { melhorar. } \\
\text { Vê a docência } \\
\text { como uma ação } \\
\text { individual }\end{array}$ & $\begin{array}{c}\text { Realização de } \\
\text { cursos, oficinas e } \\
\text { palestras } \\
\text { oferecidos para } \\
\text { todos os } \\
\text { professores. } \\
\text { Escolha de temas e } \\
\text { docentes realizada } \\
\text { pelo órgão gestor } \\
\text { ou eleita dentro de } \\
\text { uma diversidade } \\
\text { de alternativas. }\end{array}$ & $\begin{array}{l}\text { Avalição por } \\
\text { indicadores de } \\
\text { presença e } \\
\text { controle das } \\
\text { ações, sem } \\
\text { discussão de } \\
\text { resultados. } \\
\text { Registros } \\
\text { quantitativos. } \\
\text { Visibilidade } \\
\text { institucional }\end{array}$ \\
\hline $\begin{array}{c}\text { Parcial de } \\
\text { centralização }\end{array}$ & $\begin{array}{c}\text { Diversificado conforme } \\
\text { interesse e } \\
\text { necessidades. } \\
\text { Decisões pelo órgão } \\
\text { gestor, ouvindo os } \\
\text { interessados. } \\
\text { Atividades e darás } \\
\text { definidas no calendário. } \\
\text { Acompanhamento por } \\
\text { meio de alcance de } \\
\text { metas } \\
\text { Descrição de } \\
\text { quantidade e } \\
\text { qualitativa. }\end{array}$ & $\begin{array}{l}\text { A formação decorre } \\
\text { das trajetórias e da } \\
\text { reflexão do } \\
\text { docente. } \\
\text { Reconhece que os } \\
\text { professores são } \\
\text { portadores de } \\
\text { saberes e é sobre } \\
\text { ele que o } \\
\text { desenvolvimento } \\
\text { profissional se } \\
\text { alicerça. } \\
\text { Vê a docência } \\
\text { como ação } \\
\text { compartilhada, } \\
\text { sujeita às culturas } \\
\text { do campo e } \\
\text { contextos onde } \\
\text { acontecem. }\end{array}$ & $\begin{array}{l}\text { Desenvolvimento } \\
\text { de projeto } \\
\text { diferenciados } \\
\text { atendendo } \\
\text { particularidades e } \\
\text { interesse de grupos } \\
\text { e institucionais. } \\
\text { Equipes } \\
\text { institucionais } \\
\text { organizadas pelas } \\
\text { demandas (de } \\
\text { Cursos, de Projeto, } \\
\text { de Grupos etc.) }\end{array}$ & $\begin{array}{c}\text { Avalição de nível } \\
\text { de satisfação dos } \\
\text { envolvidos. Uso } \\
\text { dos dados } \\
\text { qualitativos. } \\
\text { Preocupação com } \\
\text { o tratamento e } \\
\text { socialização dos } \\
\text { dados referentes a } \\
\text { experiência. } \\
\text { Visibilidade } \\
\text { institucional }\end{array}$ \\
\hline
\end{tabular}




\begin{tabular}{|c|c|c|c|c|}
\hline Descentralizado & $\begin{array}{l}\text { Desencadeados pelos } \\
\text { grupos propositores. } \\
\text { Decisões a cargos dos } \\
\text { executores. } \\
\text { Autonomia na definição } \\
\text { de periodicidade e } \\
\text { formas de } \\
\text { acompanhamento. } \\
\text { Descrição dependente } \\
\text { dos modelos gestados } \\
\text { pelos participantes. }\end{array}$ & $\begin{array}{l}\text { A formação é auto- } \\
\text { formação e as } \\
\text { aprendizagens estão } \\
\text { situadas num tempo } \\
\text { e lugar a partir da } \\
\text { iniciativa dos } \\
\text { docentes. Envolve } \\
\text { autogestão. Aposta } \\
\text { nas iniciativas de } \\
\text { grupos mobilizados } \\
\text { por algum projeto } \\
\text { acadêmico ou } \\
\text { político. }\end{array}$ & $\begin{array}{c}\text { Estratégias } \\
\text { dependem da } \\
\text { demanda dos } \\
\text { grupos } \\
\text { Cursos pontuai, } \\
\text { sessões de estudo, } \\
\text { discussão de } \\
\text { resultados, registro } \\
\text { de campo, } \\
\text { pesquisas e } \\
\text { resolução e } \\
\text { problemas. }\end{array}$ & $\begin{array}{l}\text { Acompanhamento } \\
\text { e avaliação inter } \\
\text { pares, através de } \\
\text { meio virtuais. } \\
\text { Uso de dados } \\
\text { quanti e } \\
\text { qualitativos e } \\
\text { visibilidade para } \\
\text { os pares e grupo } \\
\text { envolvido. }\end{array}$ \\
\hline
\end{tabular}

Fonte: Volpato et al. (2014, p. 219-220).

Ao analisarmos esses modelos nos possibilitam compreender os valores e perspectivas dos gestores e grupos de assessoria pedagógicas responsáveis pela formação continuada dos professores. Nesse setor de assessoria dentro do espaço do Ensino Superior ainda há pouco reconhecimento pela comunidade acadêmica, fazendo-nos reafirmar da importância da pesquisa em detrimento do ensino. No momento que a instituição assume uma formação continuada preocupada com as questões pedagógicas, revela a preocupação com a qualidade do ensino (CUNHA, 2014), assim contribuindo para um docente que:

[...] transforma e articula os saberes dos educandos com os saberes produzidos social e culturalmente pela humanidade, para que eles se desenvolvam no mundo do trabalho, enfrentando as múltiplas demandas e transformações sociais. $\mathrm{O}$ trabalho do professor é fundamental enquanto mediador do processo de ensino e do processo de aprendizagem de seus educandos (TRERRIEN; DIAS; LEITINHO, 2016, p. 23).

As universidades têm recebido cada vez mais professores jovens e com pouca experiência profissional e conhecimento pedagógico, no entanto, expressivo conhecimento específico (CUNHA, 2014; TRERRIEN; DIAS; LEITINHO, 2016). No Entanto, na perspectiva de Soares e Cunha (2010, p. 34) a formação dos professores universitários iniciantes ocorre aproximadamente entre três e sete anos e consideram que:

não deve concebê-los como sujeitos passivos, acríticos e destituídos de conhecimentos e crenças a respeito desse nível de ensino. Eles construíram uma representação acerca da docência durante os anos em que foram estudantes universitários com base na observação sobre a forma de seus professores ensinarem e envolverem ou não os estudantes no processo de aprendizagem, na participação em projetos de pesquisa, na experiência como representante estudantil nas atividades do departamento etc. Essas e outras vivências possibilitaram ao futuro professor universitário reproduzir estilos de ser professor, mas podem ter contribuído, também, graças ao processo de reflexão, para aprender o que não deve fazer como professor em razão dos efeitos negativos da sua experiência acadêmica. 
Essa identidade virtual apresentada por Cunha (2014) e Trerrien, Dias e Leitinho (2016) se distancia da realidade encontrada, pois os professores jovens doutores investigados apresentam um conhecimento pedagógico atribuído ao longo das socializações primária e secundária, conseguindo superar alguns desafios da docência universitária, assim, se aproximando da identidade atribuída por Soares e Cunha (2010).

No entanto, essa identidade virtual discorrida por Cunha (2014) e Trerrien, Dias e Leitinho (2016) se estreita com a identidade encontrada se olharmos para o aspecto de pouca experiência profissional, pois os nossos jovens doutores apresentam de forma mais efetiva as vivências acadêmicas e de práticas esportivas. Além disso, também apresentaram um conhecimento específico expressivo, os quais foram constatados a partir currículo lattes revelando também o envolvimento e reconhecimento no contexto científico.

As pesquisas realizadas pelos jovens doutores ao longo de sua trajetória enquanto estudante e profissional, timidamente, evidenciadas como fator contribuinte em suas práticas pedagógicas. A experiência mais próxima dessa realidade foi de Felipe ao salientar sobre a contribuição da vivência com treinadores e atletas proporcionada pela pesquisa ao longo do mestrado. E a experiência de Eriberto na época da graduação e mestrado que conseguiu realizar a práticas esportivas e estudá-las no laboratório. Além disso, quando observamos as aulas dos professores não evidenciamos apontamentos sobre as pesquisas que realizam. A docente Larissa na terceira aula estava falando sobre o resultado de algumas pesquisas e mencionou uma realizada por ela, mas de forma complementar ao assunto abordado.

Esse cenário nos releva que a identidade virtual dos professores do Ensino Superior que utilizam de suas aulas para abordarem sobre seus estudos, ofuscando outros conteúdos (SOUZA; CUNHA, 2010; CUNHA, 2014; ZANCHET et al., 2014) se difere da identidade real encontrada pelos jovens doutores. Além da proximidade com a pesquisa ser restrita, e quando utilizada é de forma complementar ao que está sendo abordado.

A contribuição dos pares na sua prática pedagógica ficou evidente quando Abel faz a releitura da atividade desenvolvida por um colega em sua disciplina, para os demais, não ficou evidente essa cooperação. E isso, corrobora com as lacunas encontradas sobre o desenvolvimento das aulas com outros professores e a troca de conhecimentos entre docentes da mesma área foi limitada.

O processo reflexivo de suas aulas contribui para construção da identidade docente, pois reelabora seus saberes. Podemos considerar que isso ocorre a partir de uma discussão coletiva, a qual não é prática da docência universitária, pois se caracteriza como uma prática individual (ANASTASIOU; PIMENTA, 2010). Nesse quesito identificamos certa 
fragilidade na prática pedagógica dos jovens doutores, a construção de um planejamento individualizado ainda se faz presente.

[...] o ensino na educação superior, implica o desafio da articulação entre os saberes e os conhecimentos oriundos da produção científica na pesquisa - função constituidora da instituição de ensino superior - e a transformação desses saberes e conhecimentos em aprendizagem significativa pela mediação pedagógica no ensino - função que igualmente a constitui. Essa articulação é necessária à emancipação profissional e humana dos sujeitos na vida no mundo (TRERRIEN; DIAS; LEITINHO, 2016, p. 23).

A partir desse contexto entendemos que a formação de professor universitário dos jovens doutores ultrapassou as barreiras da pós-graduação. Entretanto, corroboramos com a perspectiva de Bolzan et al. (2013) que essa formação se desenvolve ao longo de um processo contínuo e sistemático que se utiliza das exigências sociais, psicológicas, pessoais, contextuais e profissionais como parte do desenvolvimento profissional docente. Além disso, a aprendizagem docente pode se iniciar antes da entrada da formação inicial, nas relações que estabelecemos com diferentes sujeitos e contextos (FERENC; SARAIVA, 2010).

A fim de entender a prática do professor do Ensino Superior é importante que consideremos a subjetividade da pessoa e do profissional (VEIGA, 2014). Na análise da prática pedagógica e nas narrativas dos docentes essas questões encontram-se fragilizadas em alguns pontos, pois os docentes centralizavam mais aos aspectos objetivos. Eriberto nos indicou pontos subjetivos como: a colaboração e respeito ao próximo, os quais foram considerados atributos que contribuem para sua prática atual. Outro ponto de subjetividade foi a partir das narrativas de Abel quanto seu desenvolvimento enquanto pessoa e profissional quando mudou de cidade para realizar o mestrado, e quando tornou-se pai passou a repensar sua carreira e organização profissional em detrimento de sua família.

A partir dessa discussão sobre a prática pedagógica dos jovens doutores nos reafirmam que sua configuração identitária se encontra na identidade carreirista, a qual foi construída a partir dos processos de socializações ocorridos o longo de sua trajetória pessoal e profissional. Desta forma, estreitando a concepção de Dubar (2005) sobre as identidades profissionais e sociais aos docentes universitários de Educação Física que recém finalizaram o doutorado. Além disso, os conceitos de identidade virtual e real trazidos por Goffman (1988) são identificados nesse contexto, principalmente quanto a formação pedagógica dos professores e suas práticas pedagógicas. 


\section{CONSIDERAÇÕES FINAIS}

Ao longo desta tese nos propusemos discutir a construção e desenvolvimento das práticas pedagógicas de professores universitários de Educação Física jovens doutores a partir dos processos subjetivos e objetivos da formação pessoal e profissional. Em virtude disso, utilizamos como subsídios as narrativas sobre suas histórias de vida, observações das aulas teóricas ministradas, entrevistas estruturadas, currículo lattes e planos de ensino das disciplinas que lecionam.

Cada sujeito apresenta uma trajetória pessoal e profissional com suas particularidades, pois compreendemos que cada pessoa é única e contemplada por uma identidade singular. As reações e impactos a partir do processo de socialização se desenvolvem de formas diferentes em cada um de nós. Dessa forma, respeitamos as individualidades dos professores jovens doutores, mas identificamos pontos congruentes em suas trajetórias que os conduziram para os profissionais que são hoje, como: as estreitas relações com o esporte ocorridas na socialização primária; a formação inicial e pósgraduação realizadas em instituições públicas, as quais lhes proporcionaram a participação efetiva em grupos de estudos, projetos de pesquisa e extensão.

Identificamos que o contexto familiar contribuiu para a escolha e condução profissional, mas consideramos que não foi determinante como o envolvimento com o esporte e a pesquisa científica. Assim, podemos afirmar que a construção das identidades dos professores jovens doutores foi marcada por esses dois elementos - ESPORTE E PESQUISA.

A identidade virtual que envolve os jovens doutores e os profissionais de Educação Física distinguiram, de certo modo, a identidade real dos professores investigados. No momento em que as pesquisas científicas e estudiosos criticam os motivos de ingresso para a docência universitária e sua formação pedagógica, os docentes nos revelaram: a inserção como professor no Ensino Superior não aconteceu de forma imediata, houve uma construção gradativa.

Quanto às questões pedagógicas, a literatura aborda que os docentes apresentam conhecimentos técnico-científicos e que a formação para a docência no Ensino Superior está restrita às disciplinas realizadas na pós-graduação e no estágio de docência, bem como costumam reproduzir o que vivenciaram enquanto alunos. Nesses aspectos os jovens doutores nos mostraram que a identidade real está próxima da identidade virtual, entretanto, nos relatos dos professores e nas aulas observadas, houve uma consciência de suas práticas 
e conhecimentos pedagógicos. Assim, podemos afirmar que, nesse caso, há um distanciamento entre a identidade real e virtual, pois os docentes compreendem e buscam estratégias para melhoria de suas práticas pedagógicas a partir dos conhecimentos adquiridos ao longo das socializações primária e secundária, não sustentados apenas nas disciplinas realizadas e na reprodução do que viveram como estudantes.

Há outros pontos que precisamos refletir sobre essas identidades: primeiro, os professores continuam em um processo de construção do conhecimento técnico-científico, revelando-nos que o comodismo que caracteriza os profissionais de Educação Física não se fez evidente. Enquanto estudiosos esperam que, além desses conhecimentos, os docentes universitários tenham experiências profissionais na área específica, os jovens doutores nos relevaram que o envolvimento no campo de atuação na Educação Física ficou restrito às vivências acadêmicas.

Conforme os modelos e configurações identitárias, constatamos que os jovens doutores apresentam uma identidade de responsável em promoção interna, a qual está associada de um modelo "carreirista" ao processo de mobilização. Tal perspectiva foi constatada por apresentarem uma trajetória formativa junto à instituição que lecionam; dominarem os saberes profissionais (teóricos, práticos e pedagógicos) e saberes de organização; preveem na garantia de sucesso na instituição a sua permanência no emprego, sua promoção na carreira - concurso público; há colaboração recíproca junto à instituição e aos cursos vinculados; concebem a vida profissional como uma evolução permanente predominância pela trajetória profissional; a construção da identidade relacionada ao êxito da instituição do seu profissional e social; mostram interesse na formação acadêmica e científica; há uma articulação entre a transação subjetiva e a transação objetiva, devido ao sentimento de pertencimento à instituição e à trajetória formativa nela constituída.

A configuração identitária dos jovens doutores está marcada pelas socializações primárias relacionadas ao esporte e à formação inicial, e as demais socializações secundárias associadas ao espaço formativo e profissional. Os professores Abel e Eriberto fazem uma relação das questões familiares com sua prática pedagógica, ainda, nos mostraram que há uma fragilidade na relação subjetiva, envolvendo o docente enquanto pessoa. Também identificamos que as trajetórias pessoais e profissionais dos professores se entrelaçaram não apenas em contextos institucionais, mas nos aspectos pessoais, no entanto, em nenhum momento fizeram menção a isso. Por exemplo, dois professores apresentaram convívio no espaço de grupo de pesquisa e da pós-graduação, levando-os a casarem, e nenhum dos dois fez menção ao longo da sua história de vida. 
As práticas pedagógicas dos jovens doutores nos apresentaram uma intencionalidade, a qual proporciona ao estudante uma reflexão do conteúdo abordado e aproximações com a prática. No entanto identificamos lacunas que poderão melhorá-las quanto: à construção de atividades com demais componentes curriculares e demais cursos, a fim de articular os conhecimentos e o desenvolvimento crítico dos estudantes; à proximidade com a comunidade e a prática a partir da curricularização da extensão; e usufruir e explorar as tecnologias disponíveis na instituição.

A partir das perspectivas expostas e das discussões realizadas, defendemos a tese de que os professores jovens doutores de Educação Física construíram suas práticas pedagógicas a partir das experiências e conhecimentos adquiridos ao longo das socializações primária e secundária, as quais contribuíram para a construção de suas identidades. Além disso, o esporte foi um elemento fundante em suas identidades - pessoal, social e profissional revelando que as práticas esportivas contribuíram para uma formação cidadã, mas também direciona a uma prática profissional. A experiência com a pesquisa, produções e eventos científicos são fatores que aproximam os estudantes para a pós-graduação, em consequência, da docência universitária. Assim, compreendemos que essa escolha está mais atrelada às questões científicas em relação à prática docente em si, embora o sistema universitário não contribua para uma percepção diferente devido às atribuições demasiadas à pesquisa e publicações. Também as socializações primária e secundária podem ocorrer no mesmo contexto e período, mas impactaram de forma distinta para as práticas pedagógicas dos professores jovens doutores, devido às subjetividades de cada docente.

Embora tenhamos identificado que a preocupação da universidade com as questões técnico-científicas foi mais evidente que as pedagógicas, ficamos satisfeitas com os resultados encontrados e as vivências desses profissionais, os quais mostraram ser docentes dedicados e preocupados com a formação pessoal e profissional dos acadêmicos. A cordialidade e a humildade acadêmica desses jovens doutores contribuíram para a efetivação desse estudo e somos gratas a isso, além da contribuição para nossas práticas pedagógicas.

As limitações desse estudo foram a escassez de jovens doutores em outras universidades públicas que contemplassem os critérios de inclusão desse estudo. Recomendamos para futuros estudos que se identifique a construção da prática pedagógica de professores em diferentes ciclos da carreira docente em diferentes áreas do conhecimento, não apenas na Educação Física. Além disso, buscar como se efetiva a contribuição do esporte na construção das identidades dos professores de Educação Física como de seus estudantes, considerando que é um fenômeno social. 


\section{REFERÊNCIAS}

AFONSO, Mariângela da Rosa; NOCCHI, Nice; OST, Mariana Afonso. A prática pedagógica como componente curricular: contextos e processos. In: NASCMENTO, Juarez Vieira; FARIAS, Gelcemar de Oliveira. Construção da identidade profissional em educação física: da formação à intervenção. Florianópolis: UDESC, 2012. p.305-322.

ALMEIDA, Maria Isabel de. Formação do professor do Ensino Superior: desafios e políticas institucionais. São Paulo: Cortez, 2012.

ALMEIDA, Maria Isabel; PIMENTA, Selma Garrido. A construção da pedagogia universitária no âmbito da Universidade de São Paulo. In: PIMENTA, Selma Garrido; ALMEIDA, Maria Isabel (Org.). Pedagogia Universitária: caminhos para a formação de professores. São Paulo: Cortez, 2011. p.19-43.

ALVES, Cristovan da Silva et al. Identidade profissional de professores: um referencial para pesquisa. Educação \& linguagem, São Paulo, ano 10, n. 15, p. 269-283, jan.-jun., 2007. Disponível em: < https://www.metodista.br/revistas/revistasims/index.php/EL/article/download/166/176.>. Acesso em: 08 jul. 2019.

ALVINO JUNIOR, Wilson. Formação inicial em Educação Física: análises de uma construção curricular. 2011. 272f. Tese (Doutorado em Educação) - Programa de PósGraduação em Educação, Faculdade de Educação, Universidade de São Paulo, 2011.

Formação inicial em Educação Física: análises de uma construção curricular. In: NEIRA, Marcos Garcia; NUNES, Mário Luiz Ferrati (Org.). Monstros ou heróis? Os currículos que formam professores de Educação Física. São Paulo: Phorte, 2016. p.153170.

ALVARENGA, Ana Maria. Prefácio. In: FARIAS, Gelcemar Oliveira; NASCIMENTO, Juarez Vieira de (Org.). Educação, Saúde e Esporte: novos desafios à Educação Física. Ilhéus: Editus, 2016. p.3-8

ALVINO JÚNIOR, Wilson; NEIRA, Marcos Garcia. Formação inicial em educação física e currículo: uma proposta sob a ótica de seus autores. Revista Mackenzie de Educação Física e Esporte, São Paulo, v. 12, n. 1, p. 117-138, 2013. Disponível em: <http://editorarevistas.mackenzie.br/index.php/remef/article/view/4667>. Acesso em 10 jul. 2019.ANASTASIOU, Léa das Graças Camargos. Ensinar, Aprender, Apreendr e processos de ensiagem. In: ANASTASIOU, Léa das Graças Camargos; ALVES, Leonir Pessate (Org.). Processos de ensinagem na universidade: pressupostos para as estratégias de trabalho em aula. Joinville: Ed. Univille, 2003. p.11-38.

ANGELO, Luciana Ferreira História oral e história da memória: tecendo relações. In: RUBIO, Katia (Org.). Narrativas biografias: da busca à construção de um método. São Paulo: Képos, 2016. p.91-104

AQUINO, Orlando Fernández; PUENTES, Roberto Valdés. Trabalho didático na universidade: estratégias de formação. Campinas: Editora Alínea, 2011. 
AZEVEDO, Mário Luiz Neves de; OLIVEIRA, João Ferreira de; CATANI; Afrânio Mendes. Sistema Nacional de Pós-graduação (SNPG) e o Plano Nacional de Educação (PNE 2014-2024): regulação, avaliação e financiamento. RBPAE, Goiânia, v. 32, n. 3, p. 783 - 803 set./dez. 2016. Disponível em:

<http://seer.ufrgs.br/index.php/rbpae/article/view/68576>. Acesso em: 25 jun. 2017.

BAHIA, Cristiano de Sant Anna. Formação continuada em exercício de professores de Educação Física escolar: contribuições para a prática pedagógica. 2016, 194f. Tese (doutorado) - Universidade Federal de Santa Catarina, Centro de Desportos. Programa de Pós-Graduação em Educação Física, Florianópolis, 2016. Disponível em: <https://repositorio.ufsc.br/handle/123456789/174907>. Acesso em: 12 jul. 2017.

BAIBICH-FARIA, Tânia Maria et al. O espaço da pós-graduação em educação: uma possibilidade de formação do docente da Educação Superior: cultura e compreensões dos programas de pós-graduação em Educação. In: CUNHA, Maria Isabel. Trajetórias e lugares de formação da docência universitária: da perspectiva individual ao espaço institucional. Araraquara: Junqueira e Marin, 2010. p.209-222.

BALBACHEVSKY, Elizabeth. A pós-graduação no Brasil: novos desafios para uma política bem-sucedida. In: BROCK. Colin; SCHWARTZMAN, Simon. Os desafios da educação no Brasil. Rio de Janeiro: Nova Fronteira, 2009. Disponível em: $<$ https://www.researchgate.net/profile/Elizabeth_Balbachevsky/publication/237073967_A_ pos-graduacao_no_Brasil_novos_desafios_para_uma_politica_bem_sucedida/links/0f31753835b0e7fad0000000.pdf>. Acesso em: 15 maio 2017.

BASEI, Andréia Paula. O desenvolvimento profissional e a construção da identidade do professor de Educação Física do ensino superior. Revista Mackenzie de Educação Física e Esporte, São Paulo, v. 11, n. 1, p. 44-60, 2012. Disponível em:

<http://editorarevistas.mackenzie.br/index.php/remef/article/view/2603/3463>. Acesso em: 02 jun. 2019.

. As ações pedagógicas do professor de educação física do ensino superior:

analogias com a trajetória formativa. Acta Scientiarum Education, Maringá, v. 33, n. 1, p. 37-47, 2011. Disponível em:

<http://periodicos.uem.br/ojs/index.php/ActaSciEduc/article/view/11169/11169>. Acesso em: 02 jun. 2019.

BELÃO, Mariana; MACHADO, Livia Philadelpho; MORI, Patricia Maria Martins. A formação profissional das técnicas de ginástica rítmica. Motriz, Rio Claro, v.15 n.1 p.6168, jan./mar. 2009. Disponível em: <

http://www.periodicos.rc.biblioteca.unesp.br/index.php/motriz/article/view/2139/2284>. Acesso em: 11 jul. 2017.

BENEDITO, Viceç; FERRER; Virginia.; FERRERES, Vicent. La formación universitária a debate. Barcelona: Universitat de Barcelona, 1995.

BENITES, Larissa Cerignoni; SOUZA NETO, Samuel; HUNGER, Dagmar. O processo de constituição histórica das diretrizes curriculares na formação de professores de Educação Física. Educação e Pesquisa, São Paulo, v.34, n.2, p. 343-360, maio/ago. 2008. Disponível em: 〈http://www.scielo.br/pdf/ep/v34n2/09.pdf>. Acesso em: 22 maio 2017. 
BOLZAN, Doris Pires Vargas et al. Formação de professores: a construção da docência e da atividade pedagógica na Educação Superior. Rev. Diálogo Educ., Curitiba, v. 13, n. 38, p. 49-68, jan./abr. 2013. Disponível em:

<https://periodicos.pucpr.br/index.php/dialogoeducacional/article/view/7817>. Acesso em: 08 jul. 2019.

BORGES, Luciana de Angeloni. A construção da identidade pessoal e profissional dos treinadores de basquetebol do estado de Santa Catarina. Trabalho de Conclusão de Curso (Graduação em Educação Física) - Faculdade IELUSC, Joinville, 2018

BRACHT, Valter et al. A prática pedagógica em Educação Física: a mudança a partir da pesquisa-ação. Rev. Bras. Cienc. Esporte, Campinas, v. 23, n. 2, p. 9-29, jan. 2002. Disponível em< http://www.revista.cbce.org.br/index.php/RBCE/article/view/267>. Acesso em: 10 jul. 2017.

BRAGA, Maria Margarete Sampaio de Carvalho; FAGUNDES, Maurício Cesar Vitória. Por Uma Didática Humanizadora À Luz De Paulo Freire. In: Reunião da Associação Nacional de Pós-Graduação e Pesquisa em Educação, 37, 2015. Anais eletrônicos... Florianópolis, p.1-18, 2015. Disponível em: <http://37reuniao.anped.org.br/wpcontent/uploads/2015/02/Trabalho-GT04-4613.pdf>. Acesso em: 20 dez. 2015.

BRASIL, Conselho Federal de Educação. Resolução CFE 14/1977. Diário Oficial, Brasília, 23 de novembro de 1977.

, Conselho Federal de Educação. Resolução 03/CFE/87. Brasília, 11 de março de 1987. Disponível em: <https://cref1.org.br/media/uploads/2017/05/resolucao-cfe-no03.pdf>. Acesso: 18 jul. 2018.

, Conselho Federal de Educação. Resolução no 05 de março de 1983. Fixa normas de funcionamento e credenciamento dos cursos de pós-graduação stricto sensu. Disponível em:

<http://www.capes.gov.br/images/stories/download/legislacao/Resolucao_CFE_05_1983.p df>. Acesso em: 22 maio 2017.

Conselho Federal e Conselhos Regionais de Educação Física. Lei n⿳0 9.696, de 1 de setembro de 1998. Brasília, 1 de setembro de 1998. Disponível em:

<http://www.planalto.gov.br/ccivil_03/leis/19696.htm>. Acesso em: 18 jul. 2018.

, Conselho Nacional de Saúde. Resolução n. ${ }^{\circ}$ 218, de 06 de março de 1997. Brasília, de 06 de março de 1997. Disponível em:

<http://www.crefrs.org.br/legislacao/pdf/res_cns_218_1997.pdf>. Acesso 18 jul. 2018.

Conselho Nacional de Educação - Conselho Pleno, Resolução CNE/CP no 7, de 18 de Março de 2004

Conselho Nacional de Educação - Conselho Pleno, Resolução CNE/CP no 1, de 18 de Fevereiro de 2002. Disponível em:

<http://portal.mec.gov.br/cne/arquivos/pdf/rcp01_02.pdf>. Acesso em: 17 jul. 2018 
, Conselho Nacional de Educação. Câmara de Ensino Superior. Resolução

CNE/CES 1/2001, Diário Oficial, Brasília, 3 de abril de 2001a. Disponível em: <http://portal.mec.gov.br/seed/arquivos/pdf/tvescola/leis/CES0101.pdf>. Acesso em: 18 jul. 2018.

Conselho Nacional de Educação. Plano Nacional de Educação. Lei no 10.172, de 9 de janeiro de 2001b. Disponível em:

<http://www.planalto.gov.br/ccivil_03/leis/leis_2001/110172.htm>. Acesso em: 08 jul. 2019.

, Conselho Nacional de Educação. Câmara de Ensino Superior. Parecer $\mathbf{n}^{\mathbf{0}}$ CNE/CP 28/2001, Diário Oficial, Brasília, 2 de outubro de 2001c. Disponível em: <http://portal.mec.gov.br/cne/arquivos/pdf/028.pdf>. Acesso em: 18 jul. 2018.

, Conselho Nacional de Educação. Câmara de Ensino Superior. Resolução CNE/CES 1/2007. Diário Oficial, Brasília, 8 de julho de 2007. Disponível em: <http://portal.mec.gov.br/cne/arquivos/pdf/rces001_07.pdf>. Acesso em: 26 jun. 2017.

, Conselho Nacional de Educação. Câmara de Ensino Superior. Resolução no 2, de $1^{\circ}$ de julho de 2015. Disponível em: < http://portal.mec.gov.br/docman/agosto-2017pdf/70431-res-cne-cp-002-03072015-pdf/file>. Acesso em 08 jul. 2019

Conselho Nacional de Educação. Câmara de Ensino Superior. Parecer 584/2018 de 03 de outubro de 2018a. Disponível em:

<http://www.abmes.org.br/arquivos/legislacoes/Parecer-cne-ces-584-2018-10-03.pdf >. Acesso em: 09 jul. 2019.

, Conselho Nacional de Educação. Câmara de Ensino Superior. Resolução no 7, de 18 de dezembro de 2018b. Disponível em:

$<$ http://portal.mec.gov.br/index.php?option=com_docman\&view=download\&alias $=104251$ -rces007-18\&category_slug=dezembro-2018-pdf\&Itemid=30192>. Acesso em 08 jul. 2019

, Decreto 5.800 de 8 de junho de 2006. Dispõe sobre o Sistema Universidade

Aberta do Brasil - UAB. Disponível em:

<http://www.planalto.gov.br/ccivil_03/_Ato2004-2006/2006/Decreto/D5800.htm>. Acesso em: 08 jul. 2019.

Decreto $\mathrm{n}^{\circ} 6.755$, de 29 de janeiro de 2009. Institui a Política Nacional de Formação de Profissionais do Magistério da Educação Básica, disciplina a atuação da Coordenação de Aperfeiçoamento de Pessoal de Nível Superior - CAPES no fomento a programas de formação inicial e continuada, e dá outras providências. Brasília: Casa Civil da Presidência da República Federativa do Brasil/Subsecretaria para Assuntos Jurídicos, 2009. Disponível em: <https://www.capes.gov.br/images/stories/download/legislacao/Decreto-6755-2009.pdf>. Acesso em: 17 jun. 2017.

, Decreto $n^{\circ} 67.348$, de 6 de outubro de 1970. Institui o Programa Intensivo de pós-graduação, nas áreas ligadas ao Desenvolvimento Tecnológico do País, e dá outras providências. Disponível em: <http://www2.camara.leg.br/legin/fed/decret/1970- 
1979/decreto-67348-6-outubro-1970-408882-publicacaooriginal-1-pe.html>. Acesso em: 15 maio 2017.

Decreto no 69.450, de $1^{\text {o }}$ de novembro 1971. Brasília, 1 de novembro de 1971. Disponível em: <http://www2.camara.leg.br/legin/fed/decret/1970-1979/decreto-69450-1novembro-1971-418208-publicacaooriginal-1-pe.html>. Acesso em: 18 jul. 2018.

Escola Nacional de Educação Física e Desportos. Decreto-Lei no 1.212 de 17 de abril de 1939. Diário Oficial, Rio de Janeiro, 17 de abril de 1939. Disponível em: < http://www2.camara.leg.br/legin/fed/declei/1930-1939/decreto-lei-1212-17-abril-1939349332-publicacaooriginal-1-pe.html>. Acesso em: 18 jul. 2018.

Escola Nacional de Educação Física e Desportos. Decreto-Lei n8.270 de 3 de dezembro de 1945. Diário Oficial, Rio de Janeiro, 3 de dezembro de 1945. Disponível em: <http://www2.camara.leg.br/legin/fed/declei/1940-1949/decreto-lei-8270-3-dezembro1945-457382-publicacaooriginal-1-pe.html>. Acesso em: 18 jul. 2018.

LDB: Lei de Diretrizes e Bases da Educação Nacional. Lei nº4.024/1961, fixa as diretrizes e bases da educação nacional. Brasília, de 20 de dezembro de 1961. Disponível em: <http://www.planalto.gov.br/ccivil_03/leis/L4024.htm>. Acesso em: 12 jul. 2017.

LDB: Lei de Diretrizes e Bases da Educação Nacional. Lei no 9.394, de 20 de dezembro de 1996, que estabelece as diretrizes e bases da educação nacional. Brasília: Câmara dos Deputados, Coordenação Edições Câmara, 2017. Disponível em: <http://www.planalto.gov.br/ccivil_03/Leis/L9394compilado.htm>. Acesso em: 09 ago. 2017.

Ministério da Educação. Coordenação de Aperfeiçoamento de Pessoal de Nível Superior. Plano Nacional de Pós-Graduação - PNPG 2011-2020. Brasília: CAPES, 2010. Disponível em: < http://www.capes.gov.br/plano-nacional-de-pos-graduacao>. Acesso em: 23 jun. 2017. v.1.

Parecer $n^{\circ} 977$ de 03 de dezembro de 1965. Definição dos Cursos de PósGraduação. Documenta, nº 44 do Conselho Federal de Educação, Brasília, DF, 1965. Disponível em:

<https://www.capes.gov.br/images/stories/download/legislacao/Parecer_CESU_977_1965. pdf $>$. Acesso em 15 maio 2017.

BRASILEIRO, Lívia Tenorio; AMARAL, Manoel Francisco do; PAIVA, Andrea Carla de. Producción científica en el área de educación física en Brasil: análisis de la producción de los maestros en las instituciones de formación en los estados de Paraíba y Pernambuco.

Praxis \& Saber, Tuja, v. 5, n. 10, p. 141-150, jul.-dic. 2014. Disponível em: <http://revistas.uptc.edu.co/index.php/praxis_saber/article/view/3026>. Acesso em: 10 jul. 2017.

BRUGNEROTTO, Fábio; SIMÕES, Regina. Caracterização dos currículos de formação profissional em Educação Física: um enfoque sobre saúde. Physis Revista de Saúde Coletiva, Rio de Janeiro, v.19, n. 1, p.149-172, 2009. Disponível em:

<http://www.scielo.br/scielo.php?pid=S0103-

73312009000100008\&script=sci_abstract\&tlng=pt >. Acesso em: 08 jul. 2019 
CASTELLANI FILHO, Lino. Educação Física no Brasil: a história que não se conta. 6ed. Campinas: Papirus, 2001.

CELLARD, André. A análise documental. In: POUPART, Jean et al. (Orgs.). A pesquisa qualitativa: enfoques epistemológicos e metodológicos. Petrópolis: Vozes, 2008.

COLLET, Carine et al. Formação Inicial em Educação Física no Brasil: trajetória dos cursos presenciais de 2000 a 2006. Motriz, Rio Claro, v.15, n.3, p.493-502, jul./set. 2009. Disponível em: <http://pesquisa.bvsalud.org/portal/resource/pt/lil-535196>. Acesso em: 07 abr. 2017.

COLOMBO, Bruno Dandolini; CARDOSO, Ana Lúcia Cardoso. Formação inicial em educação física e atuação na escola: a hora da verdade. Motrivivência, Florianópolis, ano 20, n. 30, p.111-127, jun. 2008

COPERVE, Comissão Permanente do Vestibular. Concurso Público para Professores. Disponível em: <https://php.coperve.ufsc.br/cpdo/editais.php>. Acesso em: 28 fev. 2017.

CORRÊA, Evandro Antonio et al. A constituição dos cursos de formação inicial em Educação Física no Brasil. R. bras. Ci. e Mov, Brasília, v. 24, n. 1, p.27-42, 2016.

CRUZ JUNIOR, Antônio Fernandes da. A produção acadêmica sobre a formação continuada de professores de Educação Física. 2010, 189 f. Dissertação (Mestrado em Educação Física) - Universidade Federal do Espírito Santos - UFES, Centro de Educação Física e Desportos, Programa de Pós-Graduação em Educação Física, Vitória, 2010. Disponível em:

<http://bdtd.ibict.br/vufind/Record/UFES_0de2dc7c7aec49b1c81053e52a4ac729>. Acesso em: 12 jul. 2017.

CRUZ, Amália dos Santos. O embate de projetos na formação de professores de Educação Física: além da dualidade licenciatura - bacharelado. Motrivivência, Florianópolis, ano. 13, n.36, p.26-44, jun. 2011. Disponível em:

$<$ https://periodicos.ufsc.br/index.php/motrivivencia/article/view/21758042.2011v23n36p26/19634>. Acesso em: 22 maio 2017.

CUNHA, Maria Isabel da (Org.). Qualidade da graduação: a relação entre ensino, pesquisa e extensão e o desenvolvimento profissional docente. Araraquara: Junqueira e Marin, 2012.

CUNHA, Maria Isabel. Bom professor e sua prática. 22. ed. Campinas: Papirus, 2010.

CUNHA, Maria Isabel. Pressupostos do desenvolvimento profissional docente e a assessoramento pedagógico na universidade em exame. In: CUNHA, Maria Isabel (Org.) Estratégias institucionais para o desenvolvimento profissional docente e as assessorias pedagógicas universitárias: memórias, experiências, desafio e possibilidades. Araraquara: Junqueira e Marin, 2014. p.27-57.

DANTAS, Flávio. Responsabilidade social e pós-graduação no Brasil: idéias para (avali)ação. R B P G, Brasília, v. 1, n. 2, p. 141-159, nov. 2004. Disponível em: 
<http://ojs.rbpg.capes.gov.br/index.php/rbpg/article/viewFile/46/43>. Acesso em: 26 jun. 2017.

DARIDO, Suraya Cristina; SANCHES NETO, Luiz. O contexto da Educação Física na Escola. In: DARIDO, Suraya Cristina; RANGEL, Irene Conceição Andrade (Org.). Educação Física na Escola: implicações para a prática pedagógica. Rio de Janeiro: Guanabara Koogan, 2005. p.1-24

DAVIS, Claudia L. F. et al. Formação continuada de professores: uma análise das modalidades e das práticas em estados e municípios brasileiros. São Paulo: FCC/DPE, 2012. Disponível em:

<http://publicacoes.fcc.org.br/ojs/index.php/textosfcc/article/view/2452/2407>. Acesso em: 10 jul. 2017.

DELGADO, Lucilia de Almeida Neves. História oral: memória, tempo, identidades. Belo Horizonte: Autêntica, 2006.

DORIGON, Thaisa Camargo; ROMANOWSKI, Joana Paulin. A reflexão em Dewey e Schön. Revista Intersaberes, Curitiba, ano 3, n. 5, p. 8 - 22, jan/jul., 2008. Disponível em: <https://www.uninter.com/intersaberes/index.php/revista/article/view/123/96>. Acesso em: 05 ago. 2017.

DORNELES, Cléia Inês Rigon; SHIGUNOV, Viktor; NASCIMENTO, Juarez Veira do. Relação teoria e prática da Educação Física no Ensino Fundamental. In: FOLLE, Alexandra; FARIAS, Gelcemar Oliveira (Orgs.). Educação Física: prática pedagógica e trabalho docente. Florianópolis: Ed. da UDESC, 2012. p.171-194.

DUBAR, Claude. A construção de Si pela atividade de trabalho: a socialização profissional. Cadernos de Pesquisa, São Paulo, v.42 n.146 p.351-367, maio/ago., 2012. Disponível em: $<$ http://www.scielo.br/scielo.php?pid=S010015742012000200003\&script=sci_abstract\&tlng=pt >. Acesso em: 10 jul. 2019.

A socialização: construção de identidades sociais e profissionais. Portugal: Porto Editora, 2005.

EMEC, Ministério da Educação. Base de dados oficial e única de informações relativas às Instituições de Educação Superior - IES e cursos de graduação do Sistema Federal de Ensino. 2017. Disponível em: <http://emec.mec.gov.br/emec/consultacadastro/detalhamento/d96957f455f6405d14c6542552b0f6eb/NTg1>. Acesso em: 28 fev. 2017.

FARIAS, Gelcemar Oliveira de et al. Preocupações pedagógicas de estudantes-estagiários na formação inicial em Educação Física. Motriz, Rio Claro, v.14, n.3, p.310-319, jul./set. 2008. Disponível em:

<http://www.periodicos.rc.biblioteca.unesp.br/index.php/motriz/article/view/2124>. Acesso em: 19 jun. 2017. 
FARIAS, Gelcemar Oliveira; SHIGUNOV, Vitor; NASCIMENTO, Juarez Vieira do. Formação e desenvolvimento profissional dos professores de Educação Física. In: SHIGUNOV, Vitor; SHIGUNOV NETO, Alexandre (Org.). A formação Profissional e a Prática Pedagógica. Londrina: O Autor, 2001. p.19-53

FERENC, Alvanize Valente Fernandes; SARAIVA, Ana Claúdia Lopes Chequer. Os professores universitários, sua formação pedagógica e suas necessidades formativas. In: DALBEN, Ângela Imaculada Loureiro de Freitas (Org.). Convergências e tensões no campo da formação e do trabalho docente. Belo Horizonte: Autêntico, 2010. p.573-589.

FERNANDES, Francisco das Chagas. Educação brasileira: indicadores e desafios: documentos de consulta. Brasília: Ministério da Educação, Secretaria Executiva, Secretaria Executiva Adjunta, 2013. Disponível em:

<http://conae2014.mec.gov.br/images/pdf/educacaobrasileiraindicadoresedesafios.pdf > Acesso em: 22 jul. 2017.

FERNANDEZ, Alzira Buse. Professores bem sucedidos no ensino superior: um estudo sobre professores sem formação pedagógica forma. 2007. 132f. Dissertação (Mestrado em Psicologia Educacional) - Pontifícia Universidade Católica de São Paulo, São Paulo, 2007.

FOLLE, Alexandra; NASCIMENTO, Juarez Vieira do. Estudos sobre desenvolvimento profissional: da escolha à ruptura da carreira docente. Revista da Educação Física/UEM, n.19, v.4, p.605-618, 4.Trim. 2008. Disponível em:

<http://www.periodicos.uem.br/ojs/index.php/RevEducFis/article/view/3521 >. Acesso em: 28 mar. 2011.

FONSECA, Dirce Mendes de. Contribuições ao debate da pós-graduação lato-sensu. R B P G, Brasília, v. 1, n. 2, p. 173-182, nov. 2004. Disponível em:

<http://ojs.rbpg.capes.gov.br/index.php/rbpg/article/view/47>. Acesso em: 26 jun. 2017.

FORMAÇÃO Continuada Para Professores. Formação continuada para professores. Disponível em: <http://portal.mec.gov.br/formacao>. Acesso em: 12 jul. 2017.

FRANCO, Maria Amélia do Rosario Santoro. Prática pedagógica e docência: um olhar a partir da epistemologia do conceito. Rev. bras. Estud. Pedagog., Brasília, v. 97, n. 247, p. 534-551, set./dez., 2016. Disponível em: <http://dx.doi.org/10.1590/S21766681/288236353>. Acesso em: 22 jul. 2017.

FRANCO, Maria Amélia Santo. Práticas Pedagógicas nas múltiplas redes educativas. In: LIBÂNEO, José Carlos; ALVEZ, Nilda. (Org.). Temas de Pedagogia - diálogos entre didática e currículo. São Paulo: Ed. Cortez, 2012. p. 169-188.

FRANCO, Maria Amélia Santoro. Prática docente universitária e a construção coletiva de conhecimentos: possibilidades de transformações no ensino-aprendizagem. IN: PIMENTA, Selma Garrido; ALMEIDA, Maria Isabel (Orgs). Pedagogia Universitária - caminhos para a formação de professores. São Paulo: Cortez, 2011, p. 159-187

FRANCO, Maria Estela Dal Pai; GENTIL, Heloisa Salles. Identidade do professor de ensino superior: questões no entrecruzar de caminhos. In: FRANCO, Maria Estela Dal Pai; 
KRAKE, Elizabeth Diefenthaeler Krahe (Org.) Pedagogia universitária e áreas de conhecimento. Porto Alegre: EdiPucrs, 2007. p.39-55.

FREIRE, Paulo. O Professor Universitário Como Educador. Revista História de la Educación, Boyacá, n. 10, p. 139-144, 2008. Disponível:

<http://www.redalyc.org/articulo.oa?id=86901009>. Acesso em: 1 dez.2015.

Pedagogia da Autonomia: saberes necessários à prática educativa. 51ed. Rio de Janeiro: Paz e Terra, 2015.

, Pedagogia da Tolerância. 2 ed. Rio de Janeiro: Paz \& Terra, 2014.

GAETA, Cecília; MASETTO, Marcos T. O professor iniciante no ensino superior: aprender, atuar e inovar. São Paulo, SENAC, 2013.

GATTI, Bernadete Angelina. Análise das políticas públicas para formação continuada no Brasil, na última década. Revista Brasileira de Educação, Rio de Janeiro, v. 13, n. 37 , p.57-70, jan./abr., 2008. Disponível em: < http://www.unitau.br/files/arquivos/category_1/GATTI__polit_pub_form_continua_1386 178939.pdf>. Acesso em: 10 jul. 2017.

GATTI, Bernadete Angelina; BARRETO, Elba Siqueira de Sá. Professores do Brasil: impasses e desafios. Brasília: UNESCO, 2009.

GATTI, Bernadete Angelina; BARRETO, Elba Siqueira de Sá; ANDRÉ, Marli Eliza Dalmazo de Afonso. Políticas docentes no Brasil: um estado da arte. Brasília: UNESCO, 2011.

GEOPCAPES, Sistema de Informações Georreferenciadas da CAPES. Distribuição de Programa de pós-graduação no Brasil em 1998, 2002, 2006, 2010 e 2014. 2016. Disponível em: <http:/geocapes.capes.gov.br/geocapes2/>. Acesso em: 04 jun. 2017.

Sistema de Informações Georreferenciadas da CAPES. Distribuição de Programa de pós-graduação no Brasil em 2017. 2018. Disponível em: <https://geocapes.capes.gov.br/geocapes/> Acesso em: 27 dez. 2018.

GIL, Antônio Carlos. Métodos e Técnicas de Pesquisa Social. 6. ed. São Paulo: Atlas, 2009a.

Metodologia do Ensino Superior. 4. ed. São Paulo: Atlas, 2009b.

GOFFMAN, Erving. Estigma: notas sobre a manipulação da identidade deteriorada. 4 ed. Rio Janeiro: LTC, 1988.

GONÇALVES, José Alberto. A carreira das professoras do ensino primário. In: NÓVOA, Antonio (Org.). Vidas de professores. 2.ed. Porto: Porto Editora, 2000. p. 141-170.

GONÇALVES, Nezilda Leci Godoy. Metodologia do Ensino da Educação Física. Curitiba: Ibpex, 2006. 
GRAÇA, Amândio. Os contextos sociais do ensino e aprendizagem dos jogos desportivos coletivos. In: NASCIMENTO, Juarez Vieira; RAMOS, Valmor; TAVARES, Fernando (Org.). Jogos desportivos: formação e investigação. Florianópolis: UDESC, 2013. p.79101.

GUARESHI, Ana Paula Dias França. Avaliação da formação e das práticas pedagógicas do docente em enfermagem. 2015. 142f. Tese (Doutorado em Gerenciamento em Enfermagem) - Escola de Enfermagem da Universidade de São Paulo, Universidade de São Paulo, São Paulo, 2015.

HENRIQUE, José; COSTA, Bruno. A escolha profissional e a indução na carreira do professor de educação física. In: HENRIQUE, J.; ANACLETO, F. N. de A.; PEREIRA, S. A. M. (Org). Desenvolvimento Profissional de Professores de Educação Física: reflexões sobre a formação e socialização docente. Curitiba: CRV, 2016. p.17-44

HUNGER, Dagmar et al. Educação Física. In: HADDAD, Ana Estela et al. (Org.). A trajetória dos cursos de graduação na área da saúde: 1991-2004. Brasília: Instituto Nacional de Estudos e Pesquisas Educacionais Anísio Teixeira, 2006. p.87-140. Disponível em: <http://www.publicacoes.inep.gov.br/portal/download/455>. Acesso em: 02 abr. 2017.

INEP - Instituto Nacional de Estudos e Pesquisas Educacionais Anísio Teixeira. Sinopse Estatística da Educação Superior 2007. Brasília: Inep, 2008. Disponível em: <http://portal.inep.gov.br/web/guest/microdados>. Acesso em: 08 jul. 2019.

. Instituto Nacional de Estudos e Pesquisas Educacionais Anísio Teixeira. Sinopse Estatística da Educação Superior 2008. Brasília: Inep, 2009. Disponível em: <http://portal.inep.gov.br/web/guest/microdados>. Acesso em: 08 jul. 2019.

. Instituto Nacional de Estudos e Pesquisas Educacionais Anísio Teixeira. Sinopse Estatística da Educação Superior 2009. Brasília: Inep, 2010. Disponível em: <http://portal.inep.gov.br/web/guest/microdados>. Acesso em: 08 jul. 2019.

. Instituto Nacional de Estudos e Pesquisas Educacionais Anísio Teixeira. Sinopse Estatística da Educação Superior 2010. Brasília: Inep, 2011. Disponível em: <http://portal.inep.gov.br/web/guest/microdados>. Acesso em: 08 jul. 2019.

. Instituto Nacional de Estudos e Pesquisas Educacionais Anísio Teixeira. Sinopse Estatística da Educação Superior 2011. Brasília: Inep, 2012 Disponível em: <http://portal.inep.gov.br/web/guest/microdados>. Acesso em: 08 jul. 2019.

. Instituto Nacional de Estudos e Pesquisas Educacionais Anísio Teixeira. Sinopse Estatística da Educação Superior 2012. Brasília: Inep, 2013 Disponível em: <http://portal.inep.gov.br/web/guest/microdados>. Acesso em: 08 jul. 2019.

. Instituto Nacional de Estudos e Pesquisas Educacionais Anísio Teixeira. Sinopse Estatística da Educação Superior 2013. Brasília: Inep, 2014 Disponível em: <http://portal.inep.gov.br/web/guest/microdados>. Acesso em: 08 jul. 2019. 
Estatística da Educação Superior 2014. Brasília: Inep, 2015. Disponível em: <http://portal.inep.gov.br/web/guest/microdados>. Acesso em: 22 maio 2017.

. Sinopse Estatística da Educação Superior 2015. Brasília: Inep, 2016. Disponível em: <http://portal.inep.gov.br/web/guest/microdados〉. Acesso em: 22 maio 2017.

Instituto Nacional de Estudos e Pesquisas Educacionais Anísio Teixeira. Sinopse

Estatística da Educação Superior 2016. Brasília: Inep, 2017 Disponível em:

<http://portal.inep.gov.br/web/guest/microdados>. Acesso em: 08 jul. 2019.

. Sinopse Estatística da Educação Superior 2017. Brasília: Inep, 2018. Disponível em: <http://portal.inep.gov.br/web/guest/sinopses-estatisticas-da-educacao-superior>. Acesso em: 27 dez. 2018.

ISAIA, Silvia Maria Aguiar. Desafios à docência superior: pressupostos a considerar. In: RISTOFF, Dilvo; SEVEGNANI, Palmira (Orgs.). Docência na educação superior. Instituto Nacional de Estudos e Pesquisas Anísio Teixeira: Brasília, 2006. p.63-84.

Professor universitário no contexto de suas trajetórias como pessoa e profissional. In: MOROSINI, Marília Costa (Org.). Professor do ensino superior: identidade, docência e formação (Org.). 2 ed. Brasília: Plano Editora, 2001.p.21-34

ISAIA, Silvia Maria Aguiar; BOLZAN, Doris Pires de Vargas. Construção da profissão docente: possibilidades e desafio para a formação. ISAIA, Silvia Maria Aguiar; BOLZAN, Doris Pires de Vargas. Pedagogia universitária e desenvolvimento profissional docente. Porto Alegre: EDIPUCRS, 2009. p.119-143.

JOAQUIM, Nathália de Fátima; BOAS, Ana Alice Vilas; CARRIERI, Alexandre de Pádua. Estágio docente: formação profissional, preparação para o ensino ou docência em caráter precário? Educ. Pesqui., São Paulo, v. 39, n. 2, p. 351-365, abr./jun., 2013. Disponível em: <http://www.scielo.br/scielo.php?script=sci_arttext\&pid=S1517-

$97022013000200005>$. Acesso em: 26 jun. 2017.

KOKUBUN, Eduardo. Pós-Graduação em Educação Física. Rev. bras. Educ. Fís. Esp., São Paulo, v.20, p.31-33, set., 2006. Suplemento n.5. Disponível em: <http://citrus.uspnet.usp.br/eef/uploads/arquivo/9_Anais_p31.pdf>. Acesso em: 25 abr. 2017.

LIBÂNEO, José Carlos. Conteúdos, formação de competências cognitivas e ensino com pesquisa: unindo ensino e modos de investigação. In: BOLZAN, Doris Pires Vargas; MACIEL, Adriana Moreira da Rocha (Orgs.). Pedagogia Universitária: tecendo redes sobre a educação superior. Santa Maria: Ed. da UFSM, 2009. p. 188-212.

LIMA, Suely Sousa. As representações sociais da identidade docente: com a palavra os professores do PROFEBPAR/UFAM. 2016. 131f. Dissertação (Mestrado em Educação) Programa de Pós-Graduação em Educação, Universidade Federal do Maranhão, São Luís, 2016. 
MACHADO, Gisele Viola; GALATTI, Larissa Rafaela; PAES, Rodrigo Rodrigues. Pedagogia do esporte e projetos sociais: interlocuções sobre a prática pedagógica. Movimento, Porto Alegre, v. 21, n. 2., p. 405-418, abr./jun. de 2015. Disponível em: <http://www.redalyc.org/pdf/1153/115339561009.pdf>. Acesso em: 08 jul. 2019.

MARCONI, Marina de Andrade; LAKATOS, Eva Maria. Fundamentos de metodologia científica. 7 ed. São Paulo: Atlas, 2010.

MARTINS, Carlos Benedito. A reforma universitária de 1968 e a abertura para o ensino superior privado no Brasil. Educ. Soc., Campinas, v. 30, n.106, p. 15-35, jan./abr. 2009. Acesso em: <http://www.scielo.br/pdf/es/v30n106/v30n106a02>. Disponível em: 05 set. 2019.

MARTINS, Nathalia; MORAES, Dirce Aparecida Foletto de; SANTOS, Adriana Regina de Jesus. Concepção Docente: a prática pedagógica em questão. In: JORNADA DE DIDÁTICA: desafios para a docência, 3, 2014. Anais... Londrina: UEL, p.190-204, 2014. Disponível em: <encurtador.com.br/hnO67 >. Acesso em: 10 jul. 2019.

MASETTO, Marcos Tarciso. Desafios para a docência no ensino superior na contemporaneidade. In: ENCONTRO NACIONAL DE PRÁTICA DE ENSINO ENDIPE, 17., 2014. E-book... Fortaleza, 2014, livro 4, p.779-795. Disponível em: <encurtador.com.br/bsvDW >. Acesso em: 25 jul. 2017

, Marcos Tarciso. Competência pedagógica do professor universitário. 3 ed. São Paulo: Summus, 2015a.

, Marcos Tarciso. Desafios para a docência universitária na contemporaneidade. São Paulo: Avercamp, 2015b.

MATIAS, Karolina Kellen. Metodologias de ensino e práticas pedagógicas em um curso de graduação em odontologia. 2013. 131f. Tese (Doutorado em Ciências da Saúde) Programa de Pós-Graduação em Ciências da Saúde, Universidade Federal de Goiás, Goiânia, 2013.

MATTOS, Mauro Gomes; ROSSETO JÚNIOR, Adriano José.; BLECHER, Shely. Teoria e Prática da Metodologia em Educação Física: construindo sua monografia, artigo e projeto de ação. São Paulo: Phorte, 2004.

MEDEIROS, Carlos Augusto de. Política de Pós-graduação Lato sensu no Brasil: configuração no período de 1964 a 1985. 2010, 210f. Tese (Doutorado em Educação) Faculdade de Educação, Universidade de São Paulo, São Paulo, 2010. Disponível em: <doi:10.11606/T.48.2010.tde-16092010-135926>. Acesso em: 14 jul. 2017.

MELO, Gislane Ferreira et al. Estereótipos aplicados aos estudantes e profissionais de Educação Física. Pensar a Prática, Goiânia, v. 21, n. 3, p. 683-689, jul./set. 2018. Disponível em: <https://www.revistas.ufg.br/fef/article/view/50466>. Acesso em: 01 jun. 2019. 
MENDES, Alessandra Dias. Atuação profissional e condições de trabalho do Educador Físico em academias de atividades física. 2010. 235f. Dissertação (Mestrado em Educação Física) - Programa de Pós-Graduação da Faculdade de Educação Física, Universidade de Brasília, 2010. Disponível em:

<http://repositorio.unb.br/handle/10482/8095>. Acesso em: 22 maio 2019.

MIRANDA, Simone. Desenvolvimento dos professores universitários de Educação Física e os ciclos de vida profissional: três estudos de caso. 455f. Tese (Doutorado em Educação Física, Lazer e Recreação) - Universidade do Minho, Instituto de Educação, Minho, 2010.

. Formação inicial do professor de Educação Física. In: Congresso Nacional de Educação, 11, 2013. Anais eletrônicos... Curitiba, p.24824-24837, 2013. Disponível em: <http://educere.bruc.com.br/arquivo/pdf2013/14122_6483.pdf >. Acesso em: 07 abr. 2017.

MOLETTA, Andréia Fernanda. A socialização profissional de professores de Educação Física do Ensino Superior. 169f (Tese). Universidade Federal de Santa Catarina - UFSC, Programa de Pós-graduação em Educação Física - PPGEF, 2013. Disponível em: <https://repositorio.ufsc.br/handle/123456789/107469?show=full>. Acesso em: 22 maio 2017.

MOREIRA, Herivelto; CALEFFE, Luiz Gonzaga. Metodologia de pesquisa para o professor pesquisador. 2. ed. Rio de Janeiro: Lamparina, 2008.

MOROSINI, Marilia Costa. (Org.) Professor do ensino superior: identidade, docência e formação. 2. ed. Brasília: Plano, 2001.

MOURA, Marla Maria Moraes. Construção Da Identidade Profissional Do Professor De Educação Física: Elementos Biográficos E Relacionais. 2015.243f. Dissertação (Mestrado em Educação) - Programa de PósGraduação em Educação, da Universidade Federal de Pernambuco - UFPE, Recife, 2015.

NASCIMENTO, Ivany Pinto; RODRIGUES, Sônia Eli Cabral. Representações sociais sobre a permanência na docência: o que dizem docentes do ensino fundamental? Educ. Pesqui., São Paulo, v. 44, p.1-16, 2018. Disponível em:

$<$ http://www.scielo.br/scielo.php?pid=S151797022018000100425\&script=sci_abstract\&tln $\mathrm{g}=\mathrm{pt}>$. Acesso em 08 jul. 2019.

NASCIMENTO, Juarez Vieira do; FARIAS, Gelcemar Oliveira (Orgs.). Construção da identidade profissional em Educação Física: a formação à intervenção. Florianópolis: Ed. da UDESC, 2012.

NEIRA, Marcos Garcia. Desvelando Frankensteins: interpretações dos currículos de Licenciatura em Educação Física. Rev. Int. de Form. de Professores (RIFP), Itapetininga, v. 2, n.2, p. 189-211, 2017. Disponível em: <https://periodicos.itp.ifsp.edu.br/index.php/RIFP/articleview/752 >. Acesso em: 10 jul. 2019. 
Os currículos que formam professores de Educação Física: a paixão pelo inimigo. In: NEIRA, Marcos Garcia; NUNES, Mário Luiz Ferrati (Org.). Monstros ou heróis? Os currículos que formam professores de Educação Física. São Paulo: Phorte, 2016. p.153170.

. Os currículos que formam professores de Educação Física e a síndrome do Estocolmo: explicações para o choque com a realidade. Educación Física y Deporte, Medellín, v. 33, n. 1, p.51-71, jul., 2014. Disponível em:

<http://www.gpef.fe.usp.br/teses/marcos_32.pdf>. Acesso em: 19 jun. 2017.

. Desvelando Frankensteins: Interpretações Dos Currículos De Licenciatura Em Educação Física. Revista Brasileira de Docência, Ensino e Pesquisa em Educação Física, Cristalina, v. 1, n. 1, p.118-140, ago., 2009. Disponível em: <http://www.gpef.fe.usp.br/teses/marcos_13.pdf>. Acesso em: 08 jul. 2019.

NOVAES, Amanda Leite. Panorama e perspectivas da/para formação continuada em Educação Física: caminhos da pós-graduação Lato Sensu na Bahia. 2009, 116 f. Dissertação (Mestrado em Educação) - Universidade Federal da Bahia - UFBA, Programa de Pós-Graduação em Educação (PPGE), Salvador, 2009.

NUNES, Marcello Pereira; VOTRE, Sebastião Josué; SANTOS; Wagner dos. O profissional em educação física no Brasil: Desafios e perspectivas no mundo do trabalho. Motriz, Rio Claro, v.18, n.2, p.280-290, abr./jun. 2012. Disponível em:

<http://www.scielo.br/pdf/motriz/v18n2/v18n2a08.pdf>. Acesso em: 22 maio 2017.

NUNES, Mário Luiz Ferrari. Frankenstein, monstros e o Ben 10: fragmentos da formação inicial em Educação Física. 2011. 287f. Tese (Doutorado em Educação) Programa de Pós-Graduação em Educação, Faculdade de Educação, Universidade de São Paulo, 2011.

. O mapa do território do Ensino Superior e da formação em Educação Física: emerge o criador. In: NEIRA, Marcos Garcia; NUNES, Mário Luiz Ferrari (Org.). Monstros ou heróis? Os currículos que formam professores de Educação Física. São Paulo: Phorte, 2016. p.17-46.

OLIVEIRA, Fátima Bayma de. Origem e evolução dos cursos de pós-graduação lato-sensu no Brasil. RAP, Rio De Janeiro, v.29, n.1, p.19·33, jan/mar., 1995. Disponível em:<http://bibliotecadigital.fgv.br/ojs/index.php/rap/article/view/8285 >. Acesso em: 17 jul. 2017.

OLIVEIRA, Jéssica Cristina Toni. A Construção Da Identidade Profissional Dos Treinadores De Voleibol De Santa Catarina: a luz dos motivos de escolha e satisfação profissional. Trabalho de Conclusão de Curso (Graduação em Educação Física) Faculdade IELUSC, Joinville, 2017

OLIVEIRA, Maria Marly. Como fazer pesquisa qualitativa. Petrópolis: Vozes, 2007. p.17-44. 
PACHANE, Graziela Giusti. Teoria e prática na formação de professores universitários: elementos para discussão. In. RISTOF, Dilvo.; SEVEGNANI, Palmira (Orgs.). Docência na educação superior. Brasília: Instituto Nacional de Pesquisas Educacionais Anísio Teixeira, 2006. p.97-145.

Formação de docentes universitários frente a um mundo em transformação. In: ISAIA, Silvia Maria de Aguiar; BOLZAN, Doris Pires de Vargas. Pedagogia Universitária e Desenvolvimento Profissional Docente. Porto Alegre: EDIPUCRS, 2009. p. 249-266. v.4.

PAGNEZ, Karina Soledad Maldonado Molina. O ser professor do Ensino Superior na área da Saúde. 2007. 192f. Tese (Doutorado em Educação) - Pontifícia Universidade Católica de São Paulo; Programa de Pós-graduação em Educação, São Paulo, 2007.

PATRIARCA, Amanda Corrêa; ONOFRE, Tiago; MASCARENHAS, Fernando. "Especialização em escolar" formação continuada de professores de educação física na Universidade Federal de Goiás: um estudo de caso. Pensar a Prática, Goiânia, v. 11, n. 3, p. 1-14, set./dez. 2008. Disponível em: <http://www.revistas.ufg.br/index.php/fef/article/view/5167/4969>. Acesso em: 12 jul. 2017.

PEREIRA, Éric Felden; MEDEIROS, Cristina Carta Cardoso de. Metodologia do ensino superior nos programas de pós-graduação Stricto Sensu em Educação Física no Brasil: a formação docente em questão. Movimento, Porto Alegre, v. 17, n. 04, p. 165-183, out/dez de 2011. Disponível em:

<http://www.seer.ufrgs.br/Movimento/article/viewFile/17806/14887>. Acesso em: 12 mar. 2017.

PIMENTA, Selma Garrido; ANASTASIOU, Léa das Graças Camargo. Docência em formação. 4. ed. São Paulo: Cortez, 2010.

PINTO, Carmem Lúcia Lascano; BARREIRO, Cristhianny Bento Barreiro; SILVEIRA, Denise do Nascimento. Formação Continuada de Professores: ampliando a compreensão acerca deste conceito. Revista Thema, Pelotas, v.7, n. 1, p.1-14, 2010. Disponível em: < http://revistathema.ifsul.edu.br/index.php/thema/article/view/19>. Acesso em: 10 jul. 2017.

PIRES, Giovani de Lorenzi; POFFO, Biana Natália. Avaliação da pós-graduação em educação física e suas implicações para os periódicos da área: "publicar ou perecer" vale também para os editores. Revista de Educação Física/IPA, v. 1, n. 1., p.03-21, 2017. Disponível em: <https://www.metodista.br/revistas/revistasipa/index.php/educacaofisica/article/view/471>. Acesso em: 08 jul. 2019.

PIRES, Veruska et al. Identidade docente e educação física: um estudo de revisão sistemática. Revista Portuguesa de Educação Física, Braga, n...30, v. 1, p. 35-60, 2017. Disponível em:

<http://www.scielo.mec.pt/scielo.php?script=sci_arttext\&pid=S087191872017000100003> . Acesso em: 08 jul. 2019.

PIZANI, Juliana; BARBOSA-RINALDI, Ieda Parra. Identidade dos cursos de licenciatura e bacharelado em Educação Física no Paraná: uma análise das áreas do conhecimento. Rev 
Bras Educ Fís Esporte, São Paulo, v.28, n. 4. p. 671-682, out-dez, 2014. Disponível em: $<$ http://www.scielo.br/scielo.php?pid=S1807-

55092014000400671\&script=sci_abstract\&tlng=pt $>$. Acesso em: 08 jul. 2019

PLATAFORMA SUCUPIRA. Cursos Avaliados e Reconhecidos - Região. 2018a.

Disponível em:

$<$ https://sucupira.capes.gov.br/sucupira/public/consultas/coleta/programa/quantitativos/qua ntitativoRegiao.jsf;jsessionid=s4pjF+rTGGF+Swt5IqlBN9cq.sucupira-204>. Acesso em: 19 dez. 2018.

Cursos Avaliados e Reconhecidos - área do conhecimento de Educação Física.

2018b. Disponível em:

<https://sucupira.capes.gov.br/sucupira/public/consultas/coleta/programa/quantitativos/qua ntitativoAreaConhecimento.jsf?areaAvaliacao=21>. Acesso em: 19 dez. 2018

PRODEGESP, Pró-reitora de Desenvolvimento e Gestão de Pessoas. Concursos Públicos - Docente Magistério Superior. Disponível em: <http://prodegesp.ufsc.br/concursospublicos-em-andamento-docente-magisterio-superior/>. Acesso em: 03 mar. 2017.

PROINFO INTEGRADO, Programa Nacional de Formação Continuada em Tecnologia Educacional. O que é. Disponível em: <http://portal.mec.gov.br/escola-degestores-da-educacao-basica/271-programas-e-acoes-1921564125/seed-

1182001145/13156-proinfo-integrado>. Acesso em: 15 jul. 2017.

RAMOS, Evódio Maurício Oliveira. Formação pedagógica de professores de uma universidade pública baiana: teares, linhas e tessituras. 2014. 172f. Dissertação (Mestrado em Educação) - Programa de Pós-Graduação em Educação, Universidade Estadual de Feira de Santana, Feira de Santana, 2014.

RAZEIRA, Maurício Berndt et al. Os motivos que levam à escolha do curso de licenciatura em educação física e as pretensas áreas de atuação. Revista Mackenzie de Educação Física e Esporte, São Paulo, v. 13, n. 2, p. 124-136, jul./dez., 2014. Disponível em: <http://editorarevistas.mackenzie.br/index.php/remef/article/view/4797>. Acesso em: 01 jun. 2019.

REDE Nacional De Formação Continuada De Professores. Apresentação. Disponível em: $<$ http://portal.mec.gov.br/rede-nacional-de-formacao-de-professores/rede-nacional-deformacao-de-professores>. Acesso em: 15 jul. 2017.

REUNI, Programa de Apoio a Planos de Reestruturação e Expansão das Universidades Federais. O que é o Reuni?. 2010. Disponível em: <http://reuni.mec.gov.br/o-que-e-oreuni>. Acesso: 22 maio 2017.

RICHARDSON, Roberto Jarry. Pesquisa social: métodos e técnicas. 3.ed. São Paulo: Atlas, 1999.

RODRIGUES, Heitor de Andrade. Formação e desenvolvimento profissional do treinador: um estudo sobre os treinadores de basquetebol, suas identidades e saberes. 2014. 249 f. Tese (Doutorado em Educação Física, na área de Biodinâmica do Movimento e Esporte) - Faculdade de Educação Física da Universidade Estadual de Campinas, 2014. 
ROMANOWSKI, Joana Paulin; MARTINS, Pura Lúcia Oliver. Formação continuada: contribuições para o desenvolvimento profissional dos professores. Rev. Diálogo Educ., Curitiba, v. 10, n. 30, p. 285-300, maio/ago., 2010. Disponível em: <http://www2.pucpr.br/reol/pb/index.php/dialogo?dd1=3607\&dd99=view\&dd98=pb>. Acesso em: 10 jul. 2017.

ROSSI, Fernanda; HUNGER, Dagmar. Dilemas contemporâneos da profissão professor: perspectivas de professores(as) de educação física da rede pública estadual de São Paulo. Revista Mackenzie de Educação Física e Esporte, São Paulo, v. 12, n. 2, p.42-58, 2013. Disponível em: <http://editorarevistas.mackenzie.br/index.php/remef/article/view/4701>. Acesso em: 08 jul. 2019

ROTHBAUER, Paulette M. Triangulation. In: GIVEN, Lisa M. (Org.). The Sage encyclopedia of qualitative research methods. Thousand Oaks: SAGE, 2008. p.892-894.

SALLES, William Neves; FARIAS, Gelcemar de Oliveira; NASCIMENTO, Juarez Vieira. Inserção profissional e formação continuada de egressos de cursos de graduação em Educação Física. Rev Bras Educ Fís Esporte, São Paulo, v. 29, n.3, p. 475-486, jul-set., 2015. Disponível em: <http://www.scielo.br/scielo.php?pid=S180755092015000300475\&script=sci_abstract\&tlng=pt>. Acesso em: 08 jul. 2019.

SANT'ANNA, Denise Bernuzzi de. Prefácio à $2^{\mathrm{a}}$ Edição. In: SOARES, Camen Lúcia (Org.). Educação Física: raízes europeias e Brasil. 5 ed. Campinas: Autores Associados, 2004.

SANTOS, José Carlos dos; SIMÕES, Regina Maria Rovigati; MOREIRA; Wagner Wey. Trajetórias formativas de acadêmicos de Educação Física da UFPI: ser ou não professor? Evidência, Araxá, v. 14, n. 14, p. 81-92, 2018. Disponível em: <https://www.uniaraxa.edu.br/ojs/index.php/evidencia/article/view/572>. Acesso em: 01 jun. 2019.

SILVA, Marcelo Moraes et al. Pós-graduação em educação física: apontamentos sobre o livro "dilemas e desafios da pós-graduação em educação física”. J. Phys. Educ. Maringá, v. 28, n.1, p.1-8, 2017. Disponível em:

<http://www.periodicos.uem.br/ojs/index.php/RevEducFis/article/view/34228>. Acesso em: 08 jul. 2019.

SILVA, Maria Aparecida. História do Currículo e currículo como construção históricocultural. In: CONGRESSO LUSO-BRASILEIRO DE HISTÓRIA DA EDUCAÇÃO, 6, 2006. Anais... Uberlândia, 2006, p. 4820-4828. Disponível em: <http://titosena.faed.udesc.br/Arquivos/Artigos_textos_historia/Curriculo.pdf>. Acesso 06 jan. 2019.

SILVA, Tomaz Tadeu da. Documentos de Identidade: Uma Introdução às Teorias de Currículo. 3 ed. Editora Autêntica. 2010.

SOARES, Carmem Lúcia. Educação Física: raízes europeias e Brasil. 5 ed. Campinas: Autores Associados, 2012. 
SOARES, Sandra Regina; CUNHA, Maria Isabel. Formação do professor: a docência universitária em busca de legitimidade [online]. Salvador: EDUFBA, 2010. Disponível em: <http://books.scielo.org/id/cb>. Acesso em: 31 jul. 2017.

SODRÉ, Marina de Lima; NEIRA, Marcos Garcia. A Formação de professores de Educação Física na Universidade de São Paulo: análise das experiências de estágio disciplinar. Caderno de Educação Física, Marechal Cândido Rondon, v. 10, n. 19, p. 1118, 2. sem., 2011. Disponível em: 〈http://www.gpef.fe.usp.br/teses/sodre_01.pdf>. Acesso em: 19 jun. 2017.

SOUZA NETO, Samuel et al. A Formação do Profissional de Educação Física no Brasil: uma história sob a perspectiva da legislação federal no século XX. Rev. Bras. Cienc. Esporte, Campinas, v. 25, n. 2, p. 113-128, jan. 2004. Disponível em:

<http://revista.cbce.org.br/index.php/RBCE/article/download/230/232. > . Acesso em: 10 jul. 2019.

STEBBINS, Robert Alan. Exploratory Research. In: GIVEN, Lisa M. (Org.). The Sage encyclopedia of qualitative research methods. Thousand Oaks: SAGE, 2008. p.327-329

TANI, Go. Os desafios da pós-graduação em educação física. Revista Brasileira de Ciências do Esporte, Campinas, v.22, p.79-90, 2000. Disponível em: <http://revista.cbce.org.br/index.php/RBCE/article/view/755/429>. Disponível em: 25 abr. 2017.

. Pós-graduação em educação física: crescimento e correção da rota. In: MOREIRA, Wagner Wey; NISTA-PICCOLO, Vilma L. (Org.). Educação física e esporte no século XXI. 1 ed. Campinas - SP: Papirus Editora, 2016. p. 153-171.

TENROLLER, Regane Maria et al. A identidade e a formação do professor da educação superior. In: CONGRESSO INTERNACIONAL DE EDUCAÇÃO, 3, 2011. Anais... Ponta Grossa: UEPG p.1-14, 2011. Disponível em:

<http://www.isapg.com.br/2011/ciepg/download.php?id=14>. Acesso em: 22 maio 2017.

THERRIEN, Jacques; DIAS, Ana Maria Iório; LEITINHO, Meirecele Calíope. Em Aberto, Brasília, v. 29, n. 97, p. 21-34, 2016. Disponível em: <http://emaberto.inep.gov.br/index.php/emaberto/article/view/3156/2682>. Acesso em: 02 jun. 2017.

THOMAS, Jerry R.; NELSON, Jack K. Métodos de pesquisa em atividade física. 3. ed. Porto Alegre: ARTMED, 2002.

VARGAS, Claudio Pellini; MOREIRA, Antonio Flavio Barbosa. A crise Epistemológica na educação física: implicações no trabalho docente. Cadernos de Pesquisa, São Paulo, v.42, n.146, p.408-427, maio/ago., 2012. Disponível em: <http://www.scielo.br/pdf/cp/v42n146/06.pdf>. Acesso em: 10 jul 2019.

. Identidades em desalinho: um estudo de campo na formação em educação física. Educação Unisinos, São Leopoldo, v. 15, n. 3, p. 214-223, set./dez., 2011. Disponível em: $<$ http://revistas.unisinos.br/index.php/educacao/article/view/edu.2011.153.06/543>. Acesso em: 02 jun. 2019. 
VEIGA, Ilma Passos Alencastro. Docência universitária na Educação Superior. In: RISTOFF, Dilvo; SEVEGNANI, Palmira. Docência na educação superior. Brasília: Instituto Nacional de Estudos e Pesquisas Educacionais Anísio Teixeira, 2006. p.85-96.

Formação de professores para a Educação Superior e a diversidade da docência. Rev. Diálogo Educ., Curitiba, v. 14, n. 42, p. 327-342, maio/ago. 2014. Disponível em: <https://periodicos.pucpr.br/index.php/dialogoeducacional/article/view/6515 >. Acesso em: 08 jul. 2019.

VELLOSO, Jacques. Mestres e doutores no país: destinos profissionais e políticas de pósgraduação. Caderno de Pesquisa, São Paulo, v.34, n.123, p.583-611, 2004. Disponível em: <http://dx.doi.org/10.1590/S0100-15742004000300005>. Acesso 17 jul. 2018.

VERDUM, Priscila. Prática Pedagógica: o que é? O que envolve?. Revista Educação por Escrito - PUCRS, Porto Alegre, v.4, n.1, p.91-105, jul. 2013. Disponível em: <http://revistaseletronicas.pucrs.br/ojs/index.php/porescrito/article/viewFile/14376/97>. Acesso em: 23 jul. 2017.

VILARTA, Roberto; GUTIERREZ, Gustavo Luis. Educação física, estrutura curricular e possibilidades de intervenção na promoção da saúde e da qualidade de vida. In: GAIO, Roberta; SEABRA JUNIOR, Luiz; DELGADO, Maurício Aníbal. Formação profissional em Educação Física. Várzea Paulista: Fontoura, 2013. p.213-227

VOLPATO, Gildo et al. A formação do docente universitário em Santa Catarina: estratégias institucionais das IES comunitárias. In: CUNHA, Maria Isabel. Estratégias institucionais para o desenvolvimento profissional docente e as assessorias pedagógicas universitárias: memórias, experiências, desafio e possibilidades. Araraquara: Junqueira e Marin, 2014. p. 215-246.

ZABALZA, Miguel. O ensino universitário: seu cenário e seus protagonistas. Porto Alegre: Artmed, 2004.

ZANCHET, Beatriz Maria B. Atrib et al. Tempos e espaços de inserção e desenvolvimento profissional de docentes universitários iniciantes. In: CUNHA, Maria Isabel. Estratégias institucionais para o desenvolvimento profissional docente e as assessorias pedagógicas universitárias: memórias, experiências, desafio e possibilidades. Araraquara: Junqueira e Marin, 2014. p.187-213.

ZEICHNER, Kenneth M. Uma análise crítica sobre a "reflexão" como conceito estruturante na formação docente. Educ. Soc., Campinas, v. 29, n. 103, p. 535-554, maio/ago., 2008. Disponível em: <www.scielo.br/pdf/es/v29n103/12.pdf>. Acesso em: 06 ago. 2017. 
ANEXOS 
ANEXO A - Autorização da Universidade Investigada para Coleta Das Informações

\section{UNIYERSIDADE DE SĀO PAULO - USP \\ PROGRAMA DE PÓS-GRADUAÇÃO EM EDUCAÇĀO - FEUSP}

\section{CARTA DE ACETTE DO CAMPO DE PESQUISA}

Eu compreendo os direitos dos participantes da pesquisa intitulada A Prática Pedagógica de Professores Universitários de Educaçâo Fisica Jovens Doutores, que visa: investigar o processo de construção da prática pedagógica de docentes da Educą̧ấo Física, jovens doutores, a partir dos processos subjetivos e objetivos da formação pessoal e profissional. Tal propósito dispőe também de suas especificidades como: reconhecer a identidade real e a identidade virtual dos docentes; identificar e compreender a construçâo e o desenvolvimento das práticas pedagógicas dos professores dos cursos de Educação Física; averiguar as implicaçốes das construçôes biográficas e subjetivas na consolidação da prática pedagógica. Sob orientação da Prof Dra. Karina Soledad Maldonado Molina e tem como pesquisadora responsável Andréia Fernanda Moletta, aluna da Faculdade de Educação da Universidade de São Paulo - FEUSP, as quais podem ser contatadas pelo e-mail andreia.moletta@usp.br ou telefone (47) 9997844-24.

Na qualidade de responsável por esta instituição, autorizo a participação dos professores dos cursos de Educação Física, enquadrados nos critérios de seleção do estudo. Compreendo como e porque esse estudo está sendo realizado.

Os responsáveis pela pesquisa garantem o sigilo, assegurando a privacidade dos participantes quanto as informações envolvidas na pesquisa. Receberei uma cópia assinada deste formulário de consentimento. Além disso, também cumpriremos o que determina as Resoluções 466/12 - CONEP/MS e 510/16, e contribuiremos com a pesquisa mencionada sempre que necessário, fornecendo informações almejadas. Sabemos que nossa instituição poderá, a qualquer fase dessa pesquisa, retirar esse consentimento. Concordamos que os resultados deste estudo sejam apresentados por escrito ou oralmente em Banca Examinadora, congressos e revistas científicas.

Colocamo-nos a disposição para qualquer dúvida que se faça necessária.

Atenciosamente,

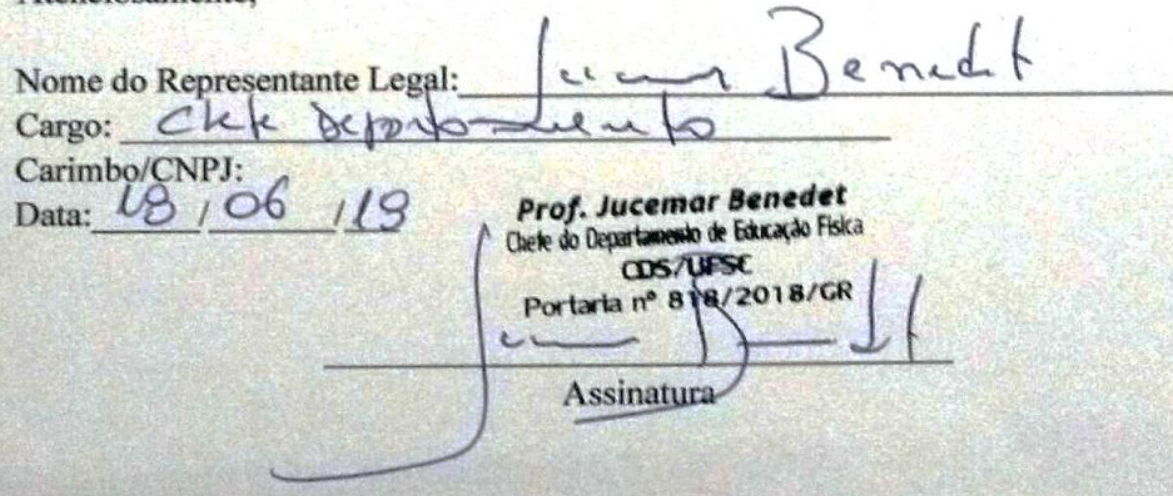


ANEXO B - Aparecer de Aprovação do Comitê de Ética de Pesquisa com Seres Humanos $-\mathrm{CEP}$

\begin{tabular}{|c|}
\hline $\begin{array}{c}\text { INSTITUTO SUPERIOR E } \\
\text { CENTRO EDUCACIONAL } \\
\text { LUTERANO BOM }\end{array}$ \\
PARECER CONSUBSTANCIADO DO CEP \\
DADOS DO PROJETO DE PESQUISA
\end{tabular}

Titulo da Pesquisa: A PRATICA PEDAGOGICA DE PROFESSORES UNIVERSITARIOS DE EDUCAÇAO
FISICA JOVENS DOUTORES Pesquisador: Andrela Fernanda Moletta

Área Tematica:

Versac: 3

CAAE: 70117917.2 .0000 .5365

Institulçăo Proponente:Assoclaçăo Educacional Luterana Bom Jesus / IELUSC

Patrocinador Princlpal: Financlamento Proprio

DADOS DO PARECER

Número do Parecer: 2.275 .650

Apresentação do Projeto:

Este e projeto de pesquisa para obtençăo do ttulo de doutoramento da pesquisadora. E um estudo de caso qualltativo do tipo descritiva e documental. Tal proposta vem ao encontro do foco almejado com esse estudo, pols busca Identincar a construçăo e o desenvolvimento da pratıca pedagogica dos professores unlversitarios de Educaçăo Flsica jovens doutores em sua essencla e profundidade. E o estudo de caso permite a anallse detalhada do processo conslderando alnda as relaçð̄es existentes.

Objetivo da Pesquisa:

Objetivo Primario

Identificar como professores unlversitarios de Educaçăo Fislca jovens doutores constroem e desenvolvem suas praticas pedagoglcas

Objetivo Secundario

- Averiguar e observar como os professores constroem e desenvolvem seus planos de ensino;

- Veriflcar 05 fundamentos pedagogico-didaticos que nortelam sua pratica docente;

- Identificar se a formaçäo critica e refexiva dos estudantes se constitul orlentaçక̆o para as praticas docentes nos cursos de Educaçăo Fisica;

- Averiguar os aspectos Inerentes a trajetoria pessoal e profissional que contribulram para atual

Enderege: Rus Princesa lasbel 438

Borro: Centro

UF: $S C$

Munioiplo: JONMUL

CEP: $89201-270$

Telatone: [47]3025-8049

E-malt: cepdeluec.br 


\section{INSTITUTO SUPERIOR E CENTRO EDUCACIONAL LUTERANO BOM}

Conthuacito do Parecoer. 2275 eso

prática docente

\section{Avaliação dos Riscos e Beneficios:}

Riscos

A investigação terá risco mínimo aos professores, como algum constrangimento devido a algum procedimento de coleta. Na observação das aulas, caso necessário o afastamento do pesquisador, será respeitado, como também na entrevista, caso o docente näo queira responder alguma pergunta.

Beneficios:

Quanto aos beneficios, este estudo está relacionado, primeiramente, aos professores jovens doutores participantes, pois poderäo refletir sobre suas práticas pedagógicas, bem como a interferência de suas experiências pessoais e profissionais no seu cotidiano docente. Além disso, aos cursos de Educação Física e aos estudantes, que poderäo verificar como estäo acontecendo às práticas dos professores universitários jovens doutores, as quais contribuem para formação de profissionais na área da Educação, da Saúde e do Esporte. Dessa forma, verificam-se em qual perspectiva os professores universitários querem formar os profissionais para atuarem na área da Educaçäo Física. Também ajudará aos cursos de pós-graduaçäo, pois poderăo averiguar como os jovens doutores estão "colocando" em prática os conhecimentos adquiridos ao longo da formação profissional, principalmente do doutoramento. A partir do procedimento de observação e de entrevista, também permitirão verificar e refletir sobre a realidade vivida pelo professor do Ensino Superior público no Brasil; e identificar as articularidades desses novos profissionais que estäo assumindo a docência nas universidades. Além de favorecer o conhecimento científico, pois estudos que tèm a preocupação com a docéncia no Ensino Superior contribuem para sanar as lacunas apresentadas na literatura.

\section{Comentários e Considerações sobre a Pesquisa:}

Metodologia está adequada aos objetivos propostos no projeto; O Referencial Teórico é atualizado e suficiente para a proposta; $O$ cronograma de execuçäo da pesquisa é coerente com os objetivos propostos e está adequado ao tempo de tramitação do projeto

Considerações sobre os Termos de apresentação obrigatória:

Foram anexados

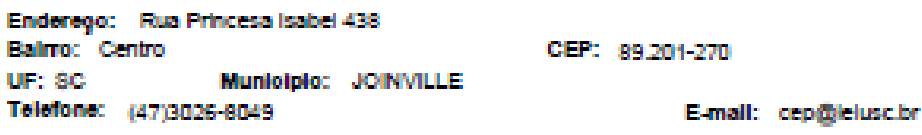




\section{INSTITUTO SUPERIOR E CENTRO EDUCACIONAL \\ LUTERANO BOM

Conthuacto do Parecer. 2275 eSO

- Apendice A Carta modelo - CARTA DE ACEITE DO CAMPO DE PESQUISA

- Cronogramas

- Roteiro para Entrevista

- Folha de rosto

- Matriz de Observação

- Quadro orçamentário

- TCLE

- Carta Resposta ao CEP

Recomendações:

Näo há

Conclusões ou Pendências e Lista de Inadequações:

Näo há pendências

Considerações Finais a critério do CEP:

Colegiado acata parecer da(o) relator(a).

Este parecer foi elaborado baseado nos documentos abaixo relacionados:

\begin{tabular}{|c|c|c|c|c|}
\hline Tipo Documento & Arquivo & Postagem & Autor & Situaçâo \\
\hline $\begin{array}{l}\text { Informaçóes Básicas } \\
\text { do Proieto }\end{array}$ & $\begin{array}{l}\text { PB_INFORMACOES_BASICAS_DO_P } \\
\text { ROJETO } 946063 \text { poff }\end{array}$ & $\begin{array}{c}15 / 08 / 2017 \\
15: 44: 55\end{array}$ & & Aceito \\
\hline Outros & Matrizdecbservacao.docx & $\begin{array}{c}15 / 08 / 2017 \\
15: 43: 59\end{array}$ & $\begin{array}{l}\text { Andréia Femanda } \\
\text { Moletta }\end{array}$ & Aceito \\
\hline Outros & Entrevista.doc $x$ & $\begin{array}{c}15 / 08 / 2017 \\
15: 43: 44 \\
\end{array}$ & $\begin{array}{l}\text { Andréia Femanda } \\
\text { Moletta }\end{array}$ & Aceito \\
\hline Outros & Autorizacasodocx & $\begin{array}{c}15 / 08 / 2017 \\
15: 43: 33 \\
\end{array}$ & $\begin{array}{l}\text { Andréia Femanda } \\
\text { Moletta }\end{array}$ & Aceito \\
\hline Outros & CartarespostaCEP.doc & $\begin{array}{c}15 / 08 / 2017 \\
15: 42: 36\end{array}$ & $\begin{array}{l}\text { Andréia Femanda } \\
\text { Moletta }\end{array}$ & Aceito \\
\hline Cronograma & cronograma.docx & $\begin{array}{c}15 / 08 / 2017 \\
15: 39: 47\end{array}$ & $\begin{array}{l}\text { Andréia Femanda } \\
\text { Moletta }\end{array}$ & Aceito \\
\hline $\begin{array}{l}\text { Projeto Detalhado / } \\
\text { Brochura } \\
\text { Investigador }\end{array}$ & ProjetoCEPTESE docx & $\begin{array}{c}15 \sqrt{0} 8 \sqrt{2} 017 \\
15: 20: 04\end{array}$ & $\begin{array}{l}\text { Andréia Femanda } \\
\text { Moletta }\end{array}$ & Aceito \\
\hline $\begin{array}{l}\text { TCLE/Termos de } \\
\text { Assentimento / } \\
\text { Justificativa de } \\
\text { Auséncia }\end{array}$ & TCLE.docX & $\begin{array}{c}15 \sqrt{08 \sqrt{2} 017} \\
15: 19: 41\end{array}$ & $\begin{array}{l}\text { Andréia Femanda } \\
\text { Moletta }\end{array}$ & Aceito \\
\hline
\end{tabular}

Enderspo: Rus Princess lagbel 439

Balro: Centro

UF: $s C$

Muniolplo: JONMLLE

Tolofone: (47)3025-8049

CEP: $89201-270$

E-mall: cephleluac be 


\section{INSTITUTO SUPERIOR E \\ CENTRO EDUCACIONAL Plotoforma LUTERANO BOM \\ Brasil}

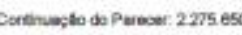

\begin{tabular}{|l|l|c|l|l|}
\hline Orçamento & Orcamento.docx & $\begin{array}{c}15,08 / 2017 \\
15: 19: 29\end{array}$ & $\begin{array}{l}\text { Andrea Femanda } \\
\text { Moletta }\end{array}$ & Aceito \\
\hline Folha de Rosto & fohaderosto.pdf & $\begin{array}{c}21 / 06 / 2017 \\
20: 57: 04\end{array}$ & $\begin{array}{l}\text { Andreia Femanda } \\
\text { Moletta }\end{array}$ & Aceito \\
\hline
\end{tabular}

Situaçăo do Parecer:

Aprovado

Necessita Apreciação da CONEP

Nằ

JOINVILLE, 14 de Setembro de 2017

Assinado por:

Solange Abrocesi lervolino

(Coordenador)

Enderego: Fua Princess labat 439

Baliro: Centro

CEP: $89201-270$

UF: $s C$

Munioiplo: JONVLLE

Tolefone: (47),3025-8049

E-mall: cepgeluacter 
ANEXO C- Aparecer da Emenda do Comitê de Ética de Pesquisa com Seres Humanos - CEP

\section{INSTITUTO SUPERIOR E CENTRO EDUCACIONAL LUTERANO BOM}

\section{PARECER CONSUBSTANCIADO DO CEP}

\section{DADOS DA EMENDA}

Título da Pesquisa: A,PRÁTICA PEDAGÓGICA DE PROFESSORES UNIVERSITÁRIOS DE EDUCAÇÃO FISICA JOVENS DOUTORES

Pesquisador: Andréia Fernanda Moletta

Área Temática:

Versäo: 4

CAAE: 70117917.2 .0000 .5365

Instituição Proponente:Associação Educacional Luterana Bom Jesus / IELUSC

Patrocinador Principal: Financiamento Próprio

DADOS DO PARECER

Número do Parecer: 2.840 .289

Apresentaçäo do Projeto:

A apresentação do projeto atende as recomendaçöes deste CEP.

Objetivo da Pesquisa:

Os objetivos da pesquisa estäo apresentados de acordo com as recomendaçôes deste CEP, conforme já considerado na relatoria anterior.

Avaliação dos Riscos e Beneficios:

As alteraçöes na avaliação dos beneficios da pesquisa foram atendidas conforme recomendava o parecer.

Comentários e Considerações sobre a Pesquisa:

Todas as alteraçōes sugeridas no parecer foram atendidas de forma adequada, com destaque para o detalhamento da elaboração da carta resposta (que indica as alterações no projeto detalhado e na plataforma brasil).

Considerações sobre os Termos de apresentação obrigatória:

O TCLE foi aterado conforme recomendaçōes do parecer

Conclusöes ou Pendências e Lista de Inadequações:

Projeto apto para execuçäo.

Considerações Finais a critério do CEP:

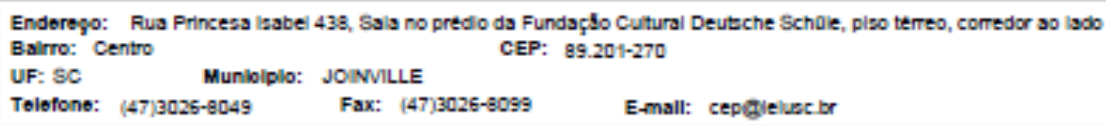




\section{INSTITUTO SUPERIOR E CENTRO EDUCACIONAL LUTERANO BOM}

Corbinuagto do Partecer: 2840200

O colegiado acata o parecer do relator e aprova o projeto.

Este parecer foi elaborado baseado nos documentos abaixo relacionados:

\begin{tabular}{|c|c|c|c|c|}
\hline Tipo Documento & Arquivo & Postagem & Autor & Situação \\
\hline $\begin{array}{l}\text { Informaçóes Básicas } \\
\text { do Projeto }\end{array}$ & $\begin{array}{l}\text { PB_INFORMAÇOES_BASICAS_118193 } \\
9 \text { Ē1.poff }\end{array}$ & $\begin{array}{c}18 / 07 / 2018 \\
12: 22-51 \\
\end{array}$ & & Aceito \\
\hline Cronograma & Cronograma2.docx & $\begin{array}{c}18 / 07 / 2018 \\
12: 21: 25 \\
\end{array}$ & $\begin{array}{l}\text { Andréia Fermanda } \\
\text { Moletta }\end{array}$ & Aceito \\
\hline $\begin{array}{l}\text { TCLE / Temos de } \\
\text { Assentimento / } \\
\text { Justificativa de } \\
\text { Auséncia }\end{array}$ & TERMODEANUENCIA.docx & $\begin{array}{c}18 / 07 / 2018 \\
12: 11: 00\end{array}$ & $\begin{array}{l}\text { Andréia Fermanda } \\
\text { Moletta }\end{array}$ & Aceito \\
\hline $\begin{array}{l}\text { TCLE / Temos de } \\
\text { Assentimento / } \\
\text { Justificativa de } \\
\text { Auséncia }\end{array}$ & TCLEPROFESSOR.docX & $\begin{array}{c}18 / 07 / 2018 \\
12: 10: 52\end{array}$ & $\begin{array}{l}\text { Andréia Femanda } \\
\text { Moletta }\end{array}$ & Aceito \\
\hline $\begin{array}{l}\text { TCLE / Temos de } \\
\text { Assentimento / } \\
\text { Justificativa de } \\
\text { Auséncia }\end{array}$ & TCLEESTUDANTE.docx & $\begin{array}{c}18 / 07 / 2018 \\
12: 10: 47\end{array}$ & $\begin{array}{l}\text { Andréia Femanda } \\
\text { Moletta }\end{array}$ & Aceito \\
\hline $\begin{array}{l}\text { Projeto Detalhado I } \\
\text { Brochura } \\
\text { Investigador }\end{array}$ & ProjetoCEPTESE2.docx & $\begin{array}{c}18 / 07 / 2018 \\
12: 10: 37\end{array}$ & $\begin{array}{l}\text { Andréia Fermanda } \\
\text { Moletta }\end{array}$ & Aceito \\
\hline Outros & CartadealteracaoCEP.doc & $\begin{array}{c}18 / 07 / 2018 \\
12: 09: 50\end{array}$ & $\begin{array}{l}\text { Andréia Femanda } \\
\text { Moletta }\end{array}$ & Aceito \\
\hline Outros & CartarespostaCEP.doc & $\begin{array}{c}15 / 08 / 2017 \\
15: 42-36\end{array}$ & $\begin{array}{l}\text { Andréia Femanda } \\
\text { Moletta }\end{array}$ & Aceito \\
\hline Orçamento & Orcamento doc $x$ & $\begin{array}{c}15 / 08 / 2017 \\
15: 19: 29 \\
\end{array}$ & $\begin{array}{l}\text { Andréia Femanda } \\
\text { Moletta }\end{array}$ & Aceito \\
\hline Folha de Rosto & folhaderosto.polf & $\begin{array}{c}21 / 06 / 2017 \\
20: 57: 04\end{array}$ & $\begin{array}{l}\text { Andréia Femanda } \\
\text { Moletta }\end{array}$ & Aceito \\
\hline
\end{tabular}

Situação do Parecer:

Aprovado

Necessita Apreciação da CONEP:

Nลั้อ

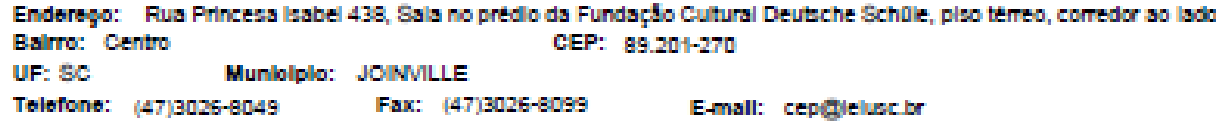


INSTITUTO SUPERIOR E

CENTRO EDUCACIONAL LUTERANO BOM

Centhuacto do Parecer: 2840 200

JOINVILLE, 23 de Agosto de 2018

Assinado por:

Solange Abrocesi lervolino

(Coordenador)

Enderego: Rua Princess lasabel 438, Sals no predlo da Fundaç\$o Cutural Deuteche Schale, plso termeo, corredor ao lado

Balrro: Centro

UF: $\mathrm{SC}$

Muniolplo: JONVILLE

CEP: $89.201-270$

Tolefone: (47) $3025-8049$ Fax: (47)3026-8099 E-mall: cepegleluec br 
APÊNDICES 
APÊNDICE A - Roteiros de questões para entrevista estruturada

\section{QUESTÕES INDIVIDUAIS PARA ENTREVISTA PROFESSOR ABEL}

1. O que você traz das experiências vividas na cidade do interior e da cultura agrícola que contornou sua infância e adolescência para atual prática docente?

2. O esporte esteve presente constantemente na sua história de vida, seja como atleta, árbitro ou gestor. Quais as contribuições dessas experiências trouxeram para sua atuação enquanto docente do Ensino Superior?

3. Em sua formação inicial, a universidade apresentava uma cultura científica muito forte e isso contribuiu para torna-se professor universitário - conforme seus relatos relate mais sobre as contribuições dessa inserção em um ambiente científico e as vivências em laboratórios na sua formação enquanto docente do Ensino Superior e para sua prática pedagógica atual.

4. Você menciona que os estudantes na época não tinham o interesse: "eu vou ser pesquisador ou professor universitário", os desejos estavam centrados na atividade de academia. Na atual realidade, você consegue identificar esse desejo nos estudantes? Você considera que sua prática docente instiga para que os estudantes tenham esse desejo de ser pesquisador ou professor universitário?

5. Você também relata que as participações em eventos científicos no início não faziam sentido para você. Na sua prática docente, você busca trazer esse sentido aos estudantes de participar em eventos científicos? Como você faz essa relação?

6. Ao longo do relato sobre sua formação inicial, você apresentou vivências na área da pesquisa e de extensão. E na sua prática também faz menção de alguns estudos realizados na área do desenvolvimento humano. Mas como você articula o ensino, pesquisa e extensão ao longo da sua prática, considerando que você trabalha em uma universidade que busca essa indissociabilidade?

7. Relata que a mudança para Florianópolis para realizar o mestrado fora de Santa Maria, em uma cidade que não conhecia, permitiu que você evoluísse. Como você relaciona essa evolução e sua atuação profissional no Ensino Superior hoje? O que essa "evolução - mudança" favoreceu ou não para o professor que é hoje.

8. Na entrevista relata sobre a contribuição de uma professora, na época do mestrado, nas questões pedagógicas, e uma delas é sobre retomar a aula do ponto da aula 
anterior, fazer uma revisão com os alunos, estimulando a participação. Na observação das três aulas, você realizada essa revisão. Como enxerga você essa estratégia de revisão para o desenvolvimento do processo de ensino-aprendizagem dos estudantes?

9. Você aponta que sua experiência na universidade do foi muito boa, pois apresentava um perfil de universidade diferente da UPC e da outra universidade no paraná o qual você estava acostumado. E essa diferença, principalmente, está relacionada pelo vínculo de um programa de pós-graduação na área da Educação Física, bem como os professores não apresentavam aproximações coma pesquisa. Na sua perspectiva, quais as diferenças e aproximações da prática docente nesses dois tipos de universidade: que possui pós-graduação vinculada ao curso de Educação Física e que não possui?

10. Relata que ficou nove anos na universidade no paraná e nesse período lecionou em diferentes componentes curriculares, e faz menção que isso o ajudou muito. Fale mais sobre esse auxílio trouxe para sua prática docente.

11. Na experiência na residência multiprofissional você relata que aprendeu sobre as metodologias ativas. Faça uma reflexão dessa vivência e sua prática docente hoje. Você consegue colocá-las em prática no curso de Educação Física Bacharelado e Licenciatura? Há diferença? Benefícios? Dificuldades?

12. Faz menção seu papel de pai e professor, e que isso fez você modificar seu modo de trabalhar. Qual foi o impacto da paternidade para sua prática docente? Quais foram essas mudanças?

13. O que você trouxe dessa experiência de Portugal e da cultura portuguesa, para sua prática enquanto professor do Ensino Superior?

14. Ao longo da observação, pude identificar que faz menção sobre a importância da leitura antes de assistirem a aula. Relate mais sobre o papel dessa estratégia pedagógica na sua prática docente.

15. O que leva você realizar feedback positivo do aluno ao perguntar ou responder algum questionamento? O que se deu sua vida como estudante faz com que você utilize em suas práticas motivações aos estudantes? Exemplo: a vivência com o professor de atletismo, a monitoria, o estágio na Educação Básica ou o Ensino superior etc.

16. Na segunda aula observada identifiquei que: Os estudantes apresentaram algumas dificuldades, pois se depararam com alguns problemas, o professor aponta: Pessoal, preciso que vocês parem e reflitam para solucionar o problema, se eu falar, fica muito fácil, mas irei explicar mais algumas coisas! Quais estratégias e recursos 
didáticos que você utiliza para contribuir para essa dificuldade de refletir para solucionar os problemas? Justifica-se o porquê da importância dessa reflexão para formação profissional desses estudantes.

\section{QUESTÕES INDIVIDUAIS PARA ENTREVISTA PROFESSORA LARISSA}

1. Ao longo da entrevista, você não mencionou uma relação com a Educação Física antes de entrar na faculdade. Você obteve alguma vivência marcante que a levou escolher o curso de Educação Física

2. Além do judô, você tem alguma experiência esportiva e/ou atividade física que antecedeu a graduação que lhe aproximou da docência no Ensino Superior e que ajude em sua prática?

3. Trecho da Entrevista: "[...] foi fundamental talvez durante a graduação ter conhecido o judô. Apesar de não ter sido atleta. E não ter envolvimento no judô eu fui monitorada da Professora [...]” (p.1). Você relata na sua entrevista que na sua graduação você conheceu o judô, permitindo ser monitora do componente curricular. Além da aproximação da modalidade, o que mais dessa vivência da graduação contribuiu para sua prática pedagógica hoje?

4. Trecho da Entrevista: “[...] A disciplina do Professor [...] também me ajudou bastante. Na minha época era um aprofundamento do Esporte, e a disciplina de vôlei que eu sei muito pouco, mas o que eu sei eu aprendi com ele. As minhas habilidades no vôlei não são muito boas, mas na disciplina não é simplesmente a prática que ele trabalhava, ele trabalhava com a formação profissional a base dos treinadores, que acredito que ainda trabalha até hoje. Então, foi uma disciplina importante que me ajudou se realmente queria dar aula [...]” (p.2). Na entrevista você aponta que a disciplina do Professor Juarez contribuiu em sua escola de dar aula (resgatar o trecho da entrevista para melhorar a explicação). O que exatamente ela contribuiu?

5. Trecho da Entrevista: "Durante minha a pós-graduação, as disciplinas foram bem importantes, pois como eu entrei direto. Então, eu não fiz uma especialização. A Bioestatística foi muito importante; Metodologia de Pesquisa, ou seja, disciplinas mais básicas, na época (Não consegui entender o complemento da frase). É o estágio de docência também foi importante no mestrado porque logo em seguida conseguir um emprego. Isso ajudou porque fato de dar aula (Não consegui entender 
o complemento da frase)” (p.2). Mais algum momento na graduação e na pósgraduação te auxiliou nessa decisão de ser docente? (Resgatar mais um trecho da entrevista)

6. Na sua primeira aula observada, faz menção sobre a prática esportiva tardia, e você se coloca como exemplo. Como você enxerga a contribuição dessa vivência na sua prática docente?

7. Além de se colocar como exemplo, você aproxima a experiência dos estudantes em sala com a temática discutida e traz exemplos de outros atletas. O que te leva realizar essa associação? Quais as contribuições podem trazer no processo de ensinoaprendizagem desses acadêmicos?

8. Aqueles acadêmicos que têm experiência mais em lutas são mais desafiadores devido as vivências práticas deles?

9. Você mencionou que entrou no concurso enquanto obtinha a titulação de mestre, pois o realizou em um período que a Lei autorizava essa entrada. Como você enxerga sua prática docente quando você era mestra e hoje doutorada na presente instituição? Houve diferença? O que melhorou, adaptou etc.?

10. Na entrevista menciona que há poucos professores especialistas na área de lutas lecionando em universidades. Como você diferente uma prática docente daquele professor especialista em lutas daquele que não apresenta tal conhecimento?

11. Trecho da entrevista: "Eu estou bem satisfeita por poder trabalhar, em certa maneira ao meu modo eu contribuo para formação dos alunos e também para o pessoal de extensão. O ano passado nós organizamos um evento de lutas em parceria com a [...]. Tenho contribuído nessa área também. E com os alunos da pósgraduação (não entendi direito a continuação da frase)” (p.3). Na entrevista você menciona que está satisfeita em contribuir na formação dos estudantes e do pessoal da extensão. Além disso, aponta que vocês (você e parceiros) realizaram um evento na área de lutas. E nas observações da primeira aula e na terceira você faz menção da realidade científica referente ao assunto (iniciação tardia no esporte) e de resultados de algumas pesquisas (sobre preparação física de atletas de judô). Nesse contexto: Qual sua perspectiva dessas aproximações de pesquisa, atividades de extensão e congressos científicos para a prática docente? Fale mais como ocorre essas aproximações ao longo de sua prática docente.

12. Na segunda aula você disponibilizou o acesso a uma competição que estava ocorrendo no mesmo horário da aula, isto é, em transmissão ao vivo. Assim deixando 
os acadêmicos assistindo mais lutas que estavam ocorrendo, além da atleta brasileira, pois tinham solicitado a você ao longo da transmissão. Desta forma ocupou mais tempo do que tinha estipulado no planejamento. Como você enxerga essa atitude dos estudantes para o processo de ensino-aprendizagem no componente curricular de lutas? Qual sua perspectiva dessa proximidade em momento real da competição, ou mesmo, da prática da modalidade para o processo de ensino-aprendizagem dos estudantes? E como recurso didático para sua prática docente?

\section{QUESTÕES INDIVIDUAIS PARA ENTREVISTA PROFESSOR FELIPE}

1. Em sua história de vida relata sua experiência esportiva no voleibol, como essa experiência contribuiu para o desenvolvimento de sua prática pedagógica?

2. Por que utiliza poucos exemplos de sua prática enquanto jogador de voleibol? Você veria possibilidades de aproximação de sua prática como jogador de voleibol com suas aulas sobre o ensino de voleibol? Como seria possível?

3. No desenvolvimento de suas aulas você cria relações entre as regras e práticas com outras modalidades, o que te fez construir essas pontes?

4. Em sua história de vida você indica uma questão importante quanto à necessidade de que as aulas devam mobilizar a reflexão dos estudantes. Isso estaria relacionado ao fato de trazer questionamentos durante sua explanação? Como tem visto os impactos desta prática em suas aulas? Percebeu-se a utilização constante de questionamentos aos estudantes ao longo das aulas, justifica-se tal atitude como?

5. A ocupação do espaço de sala de aula impacta em sua movimentação em sala? A aproximação física com os estudantes é importante para seu trabalho pedagógico? dos alunos distribuição na sala dos estudantes atrapalha sua prática? Na terceira aula percebi que estiveram mais na lateral e no fundo, fazendo com que se aproxime mais a eles.

6. Você faz menção sobre as bases de dados, e estimula a utilização a partir de uma atividade. Ao longo da sua trajetória de formação sentiu a necessidade de atividades que aproxime da pesquisa? Tal proposta veio a partir do que?

7. O que leva você realizar feedback positivo do aluno ao perguntar ou responder algum questionamento? O que se deu sua vida como estudante faz com que você utilize em 
suas práticas motivações aos estudantes? Exemplo: a vivência com o professor de atletismo, a monitoria, o estágio na Educação Básica ou o Ensino superior etc.

8. Ao longo da sua aula foram identificadas em suas falas a preocupação questão da leitura, interpretação de texto, perspectiva crítica ... O que te mobiliza a fazer isso?

9. Em sua entrevista, você relata que sua habilitação é Licenciatura Plena, assim você realizou estágios na Educação Básica. Você considera que esta experiência contribui em sua prática pedagógica hoje? Esta vivência e as experiências como atleta amador de voleibol auxiliam você a pensar as questões sobre abordagem do ensino dos esportes com crianças e a especialização precoce?

10. Ao longo da sua trajetória na formação inicial e depois no âmbito profissional você apresentou experiências fora do espaço escolar propriamente dito. Você apresentou alguma dificuldade na atuação como docente no Ensino Superior considerando que sua formação inicial é Licenciatura Plena e suas vivências práticas estiveram centradas fora do espaço escolar?

11. Quais as diferenças e aproximações da prática docente de uma instituição pública e privada?

12. Você faz menção na entrevista que pediu demissão da [...], como docente, para se dedicar ao doutorado. Você considera que essa decisão foi importante para sua atuação hoje enquanto professor? Justifique.

13. Durante as observações das aulas foram identificadas algumas avaliações como: questões sobre texto lido, trabalhos individuais e em grupo, seminários etc. Você utiliza-se de outras formas de avaliação em suas aulas? Principalmente quando realiza uma aula expositiva e dialogada? Justifique

14. Considerando suas experiências profissionais fora da docência do Ensino Superior, quais contribuições desta prática para o desenvolvimento dos conteúdos?

\section{QUESTÕES INDIVIDUAIS PARA ENTREVISTA PROFESSOR ERIBERTO}

17. O que você traz das experiências vividas enquanto filho de professores universitários para atual prática docente?

18. Ao longo da sua entrevista identifiquei que predominou a prática dos esportes individuais, diferentemente de muitas pessoas que estão sempre associadas aos esportes coletivos, principalmente ao futebol. E ao longo de suas aulas você os exemplos estão mais centrados aos esportes que você praticou. Quais as contribuições 
dessas experiências trouxeram para sua atuação enquanto docente do Ensino Superior? Você considera que essa vivência nos esportes individuais contribuiu de forma diferente para sua formação profissional e atuação docente do que as experiências dos esportes coletivos? De que forma?

19. Sua formação inicial você obteve presente a vivência em laboratórios de pesquisa relate mais sobre as contribuições dessa inserção em um ambiente científico e as vivências em laboratórios na sua formação enquanto docente do Ensino Superior e para sua prática pedagógica atual.

20. Você mencionou que na época de mestrado auxiliou outros estudantes da graduação na orientação de TCC. Você pode dizer que essa experiência te aproximou da docência universitária? O que trouxe dessa experiência para sua prática docente hoje?

21. No final do seu mestrado e depois nos oito anos seguintes você atuou em uma instituição particular em Franca, depois atuou na universidade do estado de Santa Catarina e hoje atua como docente de uma universidade federal. Para você, quais as diferenças e aproximações da prática docente de uma instituição pública e privada?

22. Você menciona na entrevista que é movido a desafios, como você relaciona esse anseio com a sua prática docente? Considera que docência te desafia? Você estimula esse espírito desafiador em seus alunos ao longo das aulas?

23. Ao longo da entrevista percebi que apenas no mestrado você realizou uma disciplina que esteve mais centrada nas questões pedagógicas para docência. Como você construiu esse conhecimento pedagógico para docência do Ensino Superior?

24. Ao longo do relato sobre sua formação inicial, você apresentou vivências na área da pesquisa. Como você articula o ensino, pesquisa e extensão ao longo da sua prática, considerando que você trabalha em uma universidade que busca essa indissociabilidade?

25. No início de suas aulas você faz um resgate da aula anterior. Como você enxerga essa estratégia de revisão para o desenvolvimento do processo de ensinoaprendizagem dos estudantes?

26. Na segunda aula observada, você está organizando um trabalho sobre treinamento intervalado e pergunta aos estudantes se eles conseguem se organizar amigavelmente. Eles falaram que não. Como você enxerga essa situação na formação profissional desses estudantes? Quais estratégias que utiliza para auxiliar nessa organização? 
27. Ao longo das aulas você realizada algumas perguntas aos estudantes. Relate mais sobre essa estratégia: como você constrói essas questões? o que te leva a utilizá-la? Etc.

28. A primeira aula, diferente das outras duas, o conteúdo abordado era mais técnico e com dificuldade de visualizando, pois, o conteúdo estava relacionado as reações químicas do organismo. Quais são suas preocupações na construção de uma aula quando o conteúdo apresenta esse teor? Quais são as estratégias utilizadas para que ocorra o processo de ensino-aprendizagem do aluno quando o conteúdo é rico em detalhes técnicos e não palpáveis?

\section{QUESTÕES COLETIVAS PARA TODOS OS PROFESSORES}

1. Como você enxerga o papel do professor na formação em Educação Física Bacharelado? Considerando que ao longo da sua entrevista faz menções sobre a presença significativa de professores em sua trajetória profissional.

2. Como define o papel do estudante no processo de aprendizagem dentro da sala de aula no curso de graduação?

3. Para você a diversificação de estratégias e técnicas impactam na metodologia de ensino em sua disciplina? Como e quais os critérios que você utiliza para essas escolhas?

4. Ao longo de suas aulas foram identificados alguns recursos didáticos e estratégias pedagógicas. Aponte quais foram as contribuições das seguintes experiências para estas escolhas: a) estudante da educação básica; b) estudante na graduação em Educação Física; c) estudante da pós-graduação lato sensu e stricto sensu; d) docente da instituição privada; e) docente de instituição pública.

5. O plano de ensino é construído individualmente ou apresenta contribuição com seus pares? Você busca desenvolver atividades relacionadas com outras disciplinas?

6. Qual sua perspectiva sobre os recursos tecnológicos para sua prática docente? Como você os utiliza? E quais?

7. Descreva o planejamento das atividades desenvolvidas na disciplina sua construção ocorre de forma individual ou articulada a outro componente curricular?

8. Faça uma reflexão a respeito de sua vivência familiar e a formação educacional, em sua escolha profissional e sua prática como docente no Ensino Superior. 
9. Para você os estudantes têm condições de relacionar ou correlacionar conteúdo dentro de sua disciplina ou com outro componente curricular?

10. Você menciona que na sua formação inicial obteve proximidade com a prática, a qual contribuiu para sua atuação hoje enquanto docente, mencionando também que se preocupada que está formando pessoas para trabalharem. Para você a relação teoria e prática seria uma responsabilidade do professor? E como articula isso em seu componente curricular?

Termo de Consentimento Livre Esclarecido - TCLE para os Professores Participantes 
APÊEDICE B - Termo de Consentimento Livre e Esclarecido aos Participantes

\section{TERMO DE CONSENTIMENTO LIVRE E ESCLARECIDO (TCLE)}

\section{RESOLUÇÃO No 466/2012 Conselho Nacional de Saúde}

Você está sendo convidado(a) a participar, como voluntário(a), de uma pesquisa desenvolvida pela doutoranda Andréia Fernanda Moletta, vinculado ao Programa de Pós-Graduação em Educação pela Faculdade de Educação da Universidade do Estado de São Paulo - FEUSP. A sua participação nesta pesquisa é fundamental para a construção da tese que tem como título “A PRÁTICA PEDAGÓGICA DE PROFESSORES UNIVERSITÁRIOS DE EDUCAÇÃO FÍSICA JOVENS DOUTORES, que está sob orientação da Professora Dra. Karina Soledad Maldonado Molina. O objetivo da pesquisa principal: investigar o processo de construção da prática pedagógica de docentes da Educação Física, jovens doutores, a partir dos processos subjetivos e objetivos da formação pessoal e profissional. Tal propósito dispõe também de suas especificidades como: reconhecer a identidade real e a identidade virtual dos docentes; identificar e compreender a construção e o desenvolvimento das práticas pedagógicas dos professores dos cursos de Educação Física; averiguar as implicações das construções biográficas e subjetivas na consolidação da prática pedagógica.

A sua participação será no preenchimento essencial neste estudo que utilizará de fontes documentais como currículo vitae, plano de ensino, cronograma das aulas e histórico escolar da graduação e pós-graduação. Também se servirá da metodologia da história oral, utilizada pela narrativa docente para compreensão da sua história de vida. E como estudo de campo usufruirá das observações das aulas teóricas. Por fim, realizará uma entrevista semiestruturada fundamentada pelas etapas anteriores.

Você terá a liberdade de se recusar a participação em qualquer dessas fases que lhe cause constrangimento e também poderá desistir da pesquisa a qualquer momento, sem que a recusa ou a desistência lhe acarrete qualquer prejuízo, bem como, caso seja de seu interesse e, mencionado ao pesquisador, terá livre acesso aos resultados do estudo.

A investigação terá risco mínimo aos professores, como algum constrangimento devido a algum procedimento de coleta. Nas observações das aulas, caso necessário o afastamento do pesquisador ou desligamento do equipamento, será respeitado, como também na entrevista, caso o docente não queira responder alguma pergunta. A sua participação constituirá de suma importância para o cumprimento do objetivo da pesquisa, além beneficiar a comunidade acadêmica, desde a formação inicial a pós-graduação, bem como aos estudantes, professores e gestores.

Você será esclarecido sobre a pesquisa em qualquer aspecto que desejar e trataremos da sua identidade com padrões profissionais de sigilo, ficando a sua identificação restrita ao grupo 
pesquisado, ou seja, sem identificação nominal. Além disso, assegura-se que nenhuma imagem será divulgada. Os resultados deste estudo serão apresentados por escrito ou oralmente em Banca Examinadora, congressos, periódicos científicos e eventos promovidos na área da Educação Física e área afins.

Em caso de dúvida, você poderá procurar a pesquisadora responsável desse estudo: Prof ${ }^{a}$ Andréia Fernanda Moletta, pelo telefone (47) 9-99784424 ou no seguinte e-mail andreia.moletta@usp.br

Atenção: Se você tiver alguma consideração ou dúvida sobre a ética que envolve a referida pesquisa, entre em contato com o Comitê de Ética em Pesquisa (CEP), pelo telefone: (47) 3026-8000 ou no endereço: Rua Princesa Isabel, 438 - Bairro Centro - CEP 89201-270- Joinville / SC.

Após ser esclarecido sobre a pesquisa, no caso de você aceitar fazer parte do estudo, assine ao final deste documento, que está em duas vias. Uma delas é sua e a outra é do pesquisador responsável.

\section{CONSENTIMENTO}

$\mathrm{Eu}$, concordo de livre e espontânea vontade em participar do estudo A PRÁTICA PEDAGógICA DE PROFESSORES UNIVERSITÁRIOS DE EDUCAÇÃO FÍSICA JOVENS DOUTORES, e esclareço que obtive todas informações necessárias.

Data: 1

Assinatura do participante da pesquisa

Declaro que obtive de forma apropriada e voluntária o Consentimento Livre e Esclarecido deste aluno e seu representante legal para a participação neste estudo.

de 2018

Pesquisador responsável: Andréia Fernanda Moletta

Assinatura: 
APÊNDICE C - Termo de Consentimento Livre e Esclarecido aos Participantes

TERMO DE CONSENTIMENTO LIVRE E ESCLARECIDO (TCLE) RESOLUÇÃO No 466/2012 Conselho Nacional de Saúde

Você está sendo convidado(a) a participar, como voluntário(a), de uma pesquisa desenvolvida pela doutoranda Andréia Fernanda Moletta, vinculado ao Programa de Pós-Graduação em Educação pela Faculdade de Educação da Universidade do Estado de São Paulo - FEUSP. A sua participação nesta pesquisa é fundamental para a construção da tese que tem como título "A PRÁTICA PEDAGÓGICA DE PROFESSORES UNIVERSITÁRIOS DE EDUCAÇÃO FÍSICA JOVENS DOUTORES, que está sob orientação da Professora Dra. Karina Soledad Maldonado Molina. O objetivo da pesquisa principal: investigar o processo de construção da prática pedagógica de docentes da Educação Física, jovens doutores, a partir dos processos subjetivos e objetivos da formação pessoal e profissional. Tal propósito dispõe também de suas especificidades como: reconhecer a identidade real e a identidade virtual dos docentes; identificar e compreender a construção e o desenvolvimento das práticas pedagógicas dos professores dos cursos de Educação Física; averiguar as implicações das construções biográficas e subjetivas na consolidação da prática pedagógica.

A sua participação será no preenchimento essencial neste estudo, pois serão realizadas as gravações das aulas do professor da disciplina que você está matriculado. Em virtude disso, participará de forma indireta, sofrendo riscos mínimos, como constrangimento ao longo das aulas. Nas observações, caso necessário o afastamento do pesquisador ou desligamento do equipamento. Em caso de recusa ou de desistência em qualquer fase da pesquisa, você não será penalizado(a) de forma alguma. A sua participação constituirá de suma importância para o cumprimento do objetivo da pesquisa, além beneficiar a comunidade acadêmica, desde a formação inicial a pós-graduação, bem como aos estudantes, professores e gestores.

Você será esclarecido sobre a pesquisa em qualquer aspecto que desejar e trataremos da sua identidade com padrões profissionais de sigilo, ficando a sua identificação restrita ao grupo pesquisado, ou seja, sem identificação nominal. Além disso, assegura-se que nenhuma imagem será divulgada. Os resultados deste estudo serão apresentados por escrito ou oralmente em Banca Examinadora, congressos, periódicos científicos e eventos promovidos na área da Educação Física e área afins.

Em caso de dúvida, você poderá procurar a pesquisadora responsável desse estudo: Prof ${ }^{a}$ Andréia Fernanda Moletta, pelo telefone (47) 9-99784424 ou no seguinte e-mail andreia.moletta@usp.br 
Atenção: Se você tiver alguma consideração ou dúvida sobre a ética que envolve a referida pesquisa, entre em contato com o Comitê de Ética em Pesquisa (CEP), pelo telefone: (47) 3026-8000 ou no endereço: Rua Princesa Isabel, 438 - Bairro Centro - CEP 89201-270- Joinville / SC.

Após ser esclarecido sobre a pesquisa, no caso de você aceitar fazer parte do estudo, assine ao final deste documento, que está em duas vias. Uma delas é sua e a outra é do pesquisador responsável.

\section{CONSENTIMENTO}

$\mathrm{Eu}$, concordo de livre e espontânea vontade em participar do estudo A PRÁTICA PEDAGógICA DE PROFESSORES UNIVERSITÁRIOS DE EDUCAÇÃO FÍSICA JOVENS DOUTORES, e esclareço que obtive todas informações necessárias.

Data: I

Assinatura do participante da pesquisa

Declaro que obtive de forma apropriada e voluntária o Consentimento Livre e Esclarecido deste aluno e seu representante legal para a participação neste estudo.

de 2018

Pesquisador responsável: Andréia Fernanda Moletta Assinatura: 